Anita Pissolito Campos

\title{
DIREITOS MORAIS NO PATRIMÔNIO CULTURAL IMATERIAL
}

\author{
DISSERTAÇ̃̃O - MESTRADO
}

Orientador: Prof. Dr. Antonio Carlos Morato

FACULDADE DE DIREITO DA UNIVERSIDADE DE SÃO PAULO

SÃo PaUlo 
Anita Pissolito Campos

\title{
DIREITOS MORAIS NO PATRIMÔNIO CULTURAL IMATERIAL
}

\author{
Dissertação de Mestrado apresentada à Banca \\ Examinadora, no âmbito do Programa de Pós- \\ Graduação da Faculdade de Direito da Universidade \\ de São Paulo, como exigência parcial para obtenção \\ do título de Mestre em Direito, sob a orientação do \\ Professor Dr. Antonio Carlos Morato. \\ Versão corrigida em 03 de dezembro de 2014. A versão \\ original, em formato eletrônico (PDF), encontra-se \\ disponível na CPG da Unidade.
}

\section{FACULDADE DE DIREITO DA UNIVERSIDADE DE SÃO PAULO SÃO PAULO}


BANCA EXAMINADORA:

Orientador:

Professor Dr. Antonio Carlos Morato

Professor

Arguidor:

Professor

Arguidor: 


\section{AGRADECIMENTOS}

Pela oportunidade de ingresso no curso de Pós-Graduação dessa Faculdade de Direito da Universidade de São Paulo e auxílio no desenvolvimento do presente trabalho, manifesto meu agradecimento ao Professor Antonio Carlos Morato que, além de me orientar neste estudo, com a revisão minuciosa de todos os capítulos e a apresentação de críticas, sugestões e ideias, serve-me de exemplo e inspiração desde os tempos em que fui sua aluna.

Agradeço também à Professora Silmara Juny de Abreu Chinellato por ter acreditado na minha capacidade e vontade de estudar este tema tão relevante e espinhoso, por seus ensinamentos e, em especial, por nos brindar com seu pensamento desafiador e coeso e sua dedicação exemplar à vida acadêmica, que também serve de inspiração.

Não posso deixar de agradecer de forma especial ao meu marido, Pedro Henrique da Silva Montanher, por estar a meu lado e compreender minhas ausências, pelo seu amor e por compartilhar trocas de fraldas, mamadeiras e todos os cuidados com nossa primeira filha em meio à realização deste estudo. Também agradeço à minha filha, Amanda Pissolito Montanher, por ter entrado em nossas vidas como um anjo e já tão pequena compreender minhas ausências para a realização deste trabalho.

Agradeço à minha mãe, Marlene, ao meu pai, Ulisses, e ao meu irmão, André, pelos valores que me ensinaram, pela escolha de vida que fizeram para estimular o aprendizado e estudo em nossas vidas, pela paciência e apoio incondicionais de sempre; este estudo não seria possível sem a ajuda de vocês. 


\section{RESUMO}

CAMPOS, Anita Pissolito. Direitos morais no patrimônio cultural imaterial. 2014. 199 f. Trabalho para Exame de Qualificação (Dissertação de Mestrado) - Departamento de Direito Civil, Faculdade de Direito do Largo São Francisco, Universidade de São Paulo (USP), São Paulo.

O presente trabalho objetiva estudar as normas que regulamentam o patrimônio cultural imaterial, no Brasil, criado, desenvolvido, preservado e detido por comunidades tradicionais identificáveis, a fim de verificar se essas comunidades possuem direitos, especialmente direitos morais relacionados a suas criações coletivas.

Para alcançar tal objetivo o trabalho buscou responder a três questionamentos, apresentados na Introdução, quais sejam: Há proteção ao patrimônio cultural imaterial detido por comunidades tradicionais, conferindo direitos a estas ou suas manifestações pertencem ao domínio público? O patrimônio cultural imaterial é objeto de direito de autor? Existem direitos morais no patrimônio cultural imaterial?

Com o intuito de responder a estes questionamentos foram analisadas as normas existentes no ordenamento jurídico brasileiro aplicáveis à regulação do patrimônio cultural imaterial, bem como realizou-se interpretação sistemática e conforme das mesmas aos termos da Constituição Federal, de forma a compreender o conteúdo destas normas, bem como a extensão dos direitos garantidos. Por fim, foram analisados casos práticos, projeto de lei e lei modelo que permitiram a construção de proposta legislativa para regular o tema.

Como principais conclusões, o trabalho pode responder aos questionamentos inicialmente apresentados de forma a constatar que existe proteção ao patrimônio cultural imaterial detido por comunidades e povos tradicionais identificáveis e que a Constituição Federal garante direitos a estes titulares, criadores e mantenedores de manifestações culturais, não se tratando, portanto, de patrimônio sujeito ao domínio público. Ainda, concluiu-se que o patrimônio cultural imaterial não é objeto do direito 
de autor por não se enquadrar em nenhuma das modalidades de obra reguladas pela Lei de Direitos Autorais. Contudo, verificou-se que há uma lacuna legislativa no tocante à regulamentação do patrimônio cultural imaterial detido por comunidades identificáveis e que para suprir tal omissão a analogia pode ser utilizada. Desta forma, considerando que tanto o patrimônio cultural imaterial, como o direito de autor buscam tutelar as "obras" produzidas a partir da criação de seu autor e que ambos possuem natureza jurídica de direito fundamental, conclui-se que os direitos morais de autor podem, por analogia, ser aplicados à tutela das comunidades e povos tradicionais criadores de manifestações culturais, ao menos até que haja legislação específica e sui generis para regular os direitos daqueles que criam e conservam patrimônio cultural imaterial.

Palavras-chave: patrimônio cultural imaterial; direitos morais coletivos; comunidades; conhecimento tradicional; manifestações culturais. 


\begin{abstract}
CAMPOS, Anita Pissolito. Moral rights at the immaterial cultural heritage. 2014. 199 f. Qualification Exam (Master's Degree) - Faculdade de Direito, Universidade de São Paulo (USP). São Paulo, 2012.
\end{abstract}

This work aims mainly at the study of the Brazilian legislation applicable to the immaterial cultural heritage created, developed, preserved and held by traditional communities, that can be identified, with the purpose of verifying if those traditional communities hold rights, specially moral rights related to their collective creations.

In order to achieve its purpose, this work answered the following main questions, presented on its Introduction Chapter: Is there any protection to immaterial cultural heritage held by traditional communities, granting them rights over it or their traditional expressions belong to public domain? Can the immaterial cultural heritage be ruled by copyright legal framework? Are there moral rights related to immaterial cultural heritage?

In order to answer those questions the Brazilian legal framework related to immaterial cultural heritage were analyzed and interpreted as a system pursuant to Brazilian Federal Constitution with the view of understanding the exact content of such rules and the extension of the rights granted. Finally, some cases were also analyzed, as well as law drafts and model-law, which allowed the construction of a proposition to regulate the rights related to immaterial cultural heritage.

As main conclusions of such work, it is possible to answer the three questions previously presented, considering that exists legal protection to immaterial cultural heritage held by traditional communities and that Federal Constitution grants certain rights to traditional communities that hold, create and maintain cultural expressions, which shall not be considered public domain. Also it is possible to conclude that immaterial cultural heritage in not the object of copyright law and since 
there is an omission on Brazilian legal framework applicable to immaterial cultural heritage held by identifiable traditional communities, analogy can be used to fulfill such omission. Therefore, considering that immaterial cultural heritage as well as copyrights intend to protect the "creation" developed by its author and that both shall be considered as fundamental right, regarding its nature, it is possible to conclude that moral rights shall also be applied to protect traditional communities rights over their cultural expression, at least until a specific sui generis legislation is developed to protect the rights belonging to communities that create and develop immaterial cultural heritage.

Keywords: immaterial cultural heritage; collective copyrights; communities; traditional knowledge. 


\section{Sumário}

1. INTRODUÇÃ

2. O PATRIMÔNIO CULTURAL IMATERIAL .......................................................... 21

2.1 Proteção ao patrimônio cultural no Brasil ............................................................ 24

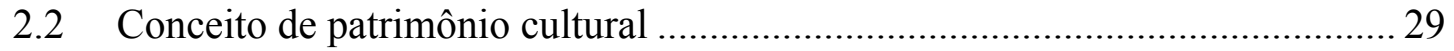

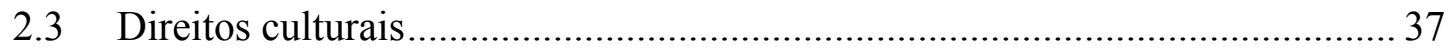

2.3.1 Ressalva quanto à terminologia adotada ............................................ 41

2.3.1.1 Manifestações culturais .......................................................... 41

2.3.1.2 Comunidades tradicionais..................................................... 45

2.4 Natureza jurídica do patrimônio cultural imaterial......................................... 47

2.5 Normas aplicáveis ao patrimônio cultural imaterial ...................................... 61

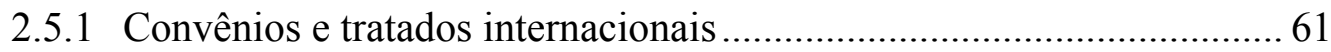

2.5.2 Demais normas que regulam o patrimônio cultural imaterial ............... 76

2.5.2.1 Decreto n. $^{\mathrm{o}} 3.551$, de 4 de agosto de 2000 ............................. 76

2.5.2.2 Decreto n. ${ }^{\circ}$ 6.884, de 7 de maio de 2009................................. 77

2.5.2.3 Lei de Direitos de Autorais ........................................................ 78

2.5.2.4 Portaria Funai n. ${ }^{\circ} 177$, de 16 de fevereiro de $2006 \ldots \ldots \ldots \ldots \ldots . . . . .82$

2.6 A tutela pelo Instituto do Patrimônio Histórico e Artístico Nacional e a ação declaratória de descumprimento de preceito fundamental ............................. 84

2.7 Sujeito de direitos do patrimônio cultural imaterial e objeto de tutela.............. 87

3. A PROPRIEDADE INTELECTUAL E OS DIREITOS DA PERSONALIDADE ... 91

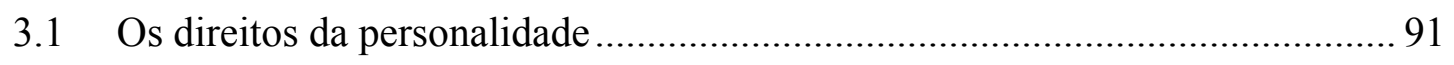

3.1.1 Histórico e extensão dos direitos da personalidade............................. 94

3.1.2 Direito da personalidade de povos e comunidades tradicionais........... 99

3.2 Natureza jurídica do direito da personalidade ............................................ 102 


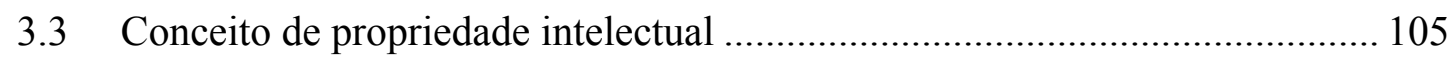

3.3.1 A natureza jurídica da propriedade intelectual....................................... 107

3.4 Conceito de direito de autor....................................................................... 113

3.4.1 A natureza jurídica do direito de autor ................................................ 116

3.4.2 Objeto do direito de autor.................................................................... 121

3.4.3 Direitos morais de autor ..................................................................... 123

3.4.4 Titularidade do direito de autor ........................................................ 128

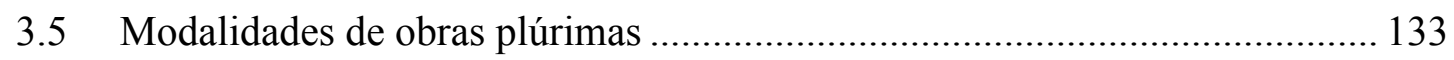

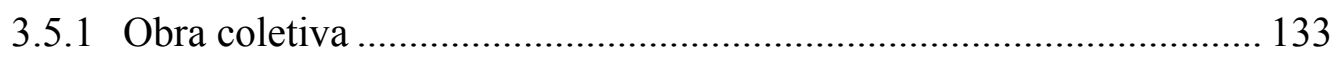

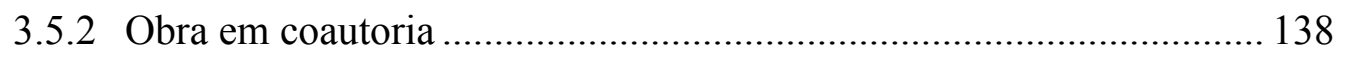

3.5.3 Obra compósita ………………………………………………….... 141

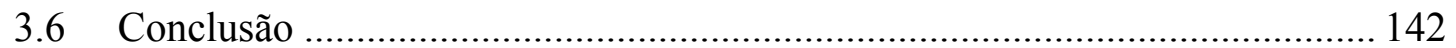

4. INTERPRETAÇÃO DA REGULAMENTAÇÃO DO PATRIMÔNIO CULTURAL IMATERIAL CONFORME A CONSTITUIÇÃO.............................. 146

4.1 Regime de tutela do patrimônio cultural imaterial: direitos culturais ............. 147

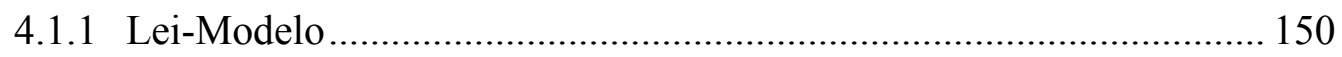

4.1.2 Direitos morais no patrimônio cultural imaterial ................................. 152

4.2 Dificuldades na proteção ao patrimônio cultural imaterial e violações de direitos em seu uso ................................................................................... 168

4.2.1 Dificuldades da tutela dos patrimônios culturais imateriais em um

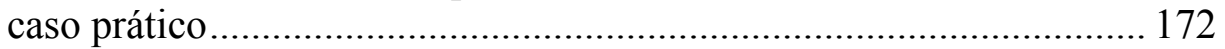

4.3 Disposições identificadas para uso do patrimônio cultural imaterial ............... 176

5. PROPOSTA DE REGULAMENTAÇÃO DO PATRIMÔNIO CULTURAL

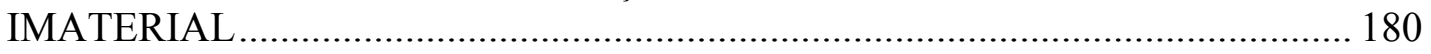

5.1 Análise de Projeto de Lei......................................................................... 180

5.2 Proposta de regime sui generis aplicável ao patrimônio cultural imaterial.... 184 
REFERÊNCIAS

193

Normas e acórdãos consultados

201

Sites consultados

Error! Bookmark not defined. 


\section{Lista de Abreviaturas}

\begin{tabular}{|r|l|}
\hline CDB & Convenção sobre Diversidade Biológica. \\
\hline Constituição & $\begin{array}{l}\text { Constituição da República Federativa do Brasil, promulgada em } \\
\text { ou, Constituição Federal de 1988. }\end{array}$ \\
\hline CTA & Conhecimento tradicional associado \\
\hline MP & Medida Provisória n. ${ }^{\text {o } 2.186-16 / 2001 ~}$ \\
\hline PCI & Patrimônio Cultural Imaterial \\
\hline PL & Projeto de Lei \\
\hline STF & Supremo Tribunal Federal \\
\hline STJ & Superior Tribunal de Justiça \\
\hline LDA & Lei de Direitos Autorais \\
\hline Funai & Fundação Nacional do Índio \\
\hline
\end{tabular}

Os dispositivos citados sem a indicação do texto legislativo a que pertencem são do Código Civil de 2002 (Lei n. ${ }^{\circ}$ 10.406/2002) 


\section{Capítulo 1 \\ INTRODUÇÃO}

O Brasil é um país com grande diversidade cultural, dado que constituído, ao longo de sua história, pela interação de diversos grupos, como os povos indígenas, portugueses, holandeses, italianos, africanos, árabes, japoneses, judeus, ciganos, entre outros, ${ }^{1}$ que compartilharam seus modos de fazer, viver e criar, isto é, sua cultura. Essa diversidade cultural expressa-se pela riqueza de manifestações culturais nacionais, que incluem a variedade de línguas, de formas de comunicação, dos modos de caça, construção, alimentação, assim como as crenças, as festividades, as criações intelectuais, entre outros, dos diversos grupos que contribuem para o processo civilizatório nacional. Assim, manifestações festivas como o carnaval, a festa do boi, o uso do chá de camomila como calmante são manifestações da cultura brasileira, e sua conservação é necessária para a manutenção da diversidade e da identidade ${ }^{2}$ cultural nacional.

Considerando a diversidade das manifestações culturais, algumas difundidas nacionalmente, como o carnaval e outras preservadas no seio das comunidades e povos que a criaram, como a lenda de determinado povo indígena, devem todas estas manifestações ser tratadas e protegidas da mesma forma? Deveriam todas elas ser consideradas manifestações integrantes do patrimônio cultural imaterial brasileiro? A Constituição Federal responde a esses questionamentos, pois em reconhecimento à importância da diversidade cultural o artigo 215 da Constituição Federal dispõe não apenas que cabe ao Estado garantir a todos o pleno exercício dos direitos culturais e o acesso à cultura, mas também estabelece que é competência do

BRAYNER, Natália Guerra. Patrimônio cultural imaterial: para saber mais. Brasília: IPHAN, 2007. p. 8-10.

2 A identidade de um indivíduo é construída a partir das relações que estabelece ao longo de sua vida, seu local de origem e onde vive, seu jeito de falar e tudo o que o diferencia e o torna único. A identidade cultural cria-se a partir do compartilhamento de memórias, histórias. De acordo com Natália Guerra Brayner, "as pessoas estão ligadas por um passado comum e por uma mesma língua, por costumes, crenças e saberes comuns, coletivamente partilhados. A cultura e a memória são elementos que fazem com que as pessoas se identifiquem umas com as outras, ou seja, reconheçam que têm e partilham vários traços em comum. Nesse sentido, pode-se falar da identidade cultural de um grupo social" (Idem, ibidem, p. 7). 
Estado proteger as manifestações das culturas populares, indígenas, afro-brasileiras e das de outros grupos que participem do processo civilizatório nacional. Com essa previsão, parece claro que a Constituição garantiu um tratamento diferenciado às manifestações culturais detidas por comunidades e povos tradicionais, especialmente aquelas que não estão difundidas nacionalmente.

Nesse sentido, interessante notar que, mesmo antes da atual Constituição Federal, Antônio Chaves ${ }^{3}$ já reconhecia em sua obra de 1987 a existência de determinadas manifestações culturais que são expressão da identidade, da religiosidade e dos valores de determinado grupo ou comunidade tradicional. Segundo esse entendimento, trata-se de bens culturais dessas comunidades, e não seria possível admitir que o direito nacional reconhecesse que tais manifestações desenvolvidas e preservadas no âmbito dessas comunidades pudessem ser apropriadas por terceiros, muitas vezes até com fins de exploração comercial - para agregar valor a um produto ou marca -, sem que isso implicasse qualquer reconhecimento ou retribuição à comunidade desenvolvedora da manifestação. ${ }^{4}$

Justamente em alinhamento com o sustentado por Antônio Chaves, a Constituição Federal veio reconhecer, além do direito ao acesso à cultura, como dever do Estado, o direito de povos e comunidades tradicionais que contribuíram para o processo civilizatório nacional. Ocorre que, da forma como as normas do ordenamento jurídico nacional vêm sendo interpretadas, de fato identifica-se que os direitos garantidos constitucionalmente às manifestações culturais desses povos e comunidades não estão sendo reconhecidos. Por esse motivo, a presente pesquisa pretende verificar se existem direitos garantidos às comunidades e povos tradicionais para a proteção de suas manifestações culturais, a partir da interpretação e aplicação da legislação vigente e aplicável ao patrimônio cultural imaterial.

Este trabalho pretende, portanto, reconhecer o conceito e a regulamentação aplicáveis ao patrimônio cultural imaterial - dado que atualmente existem normas claras para tutelar e proteger o patrimônio cultural material, mas não tão

3 CHAVES, Antônio. Direitos de autor: princípios fundamentais. Rio de Janeiro: Forense, 1987. p. 97-98.

$4 \quad$ Idem, ibidem, p. 90-92. 
evidentes no que tange ao patrimônio cultural imaterial -, identificando as diferentes nuances da regulamentação sobre o tema para os distintos casos de manifestação cultural imaterial, ou seja, para o caso da manifestação já integrada e do conhecimento do povo brasileiro, daquelas difundidas apenas em esfera regional. Em especial, este trabalho objetiva verificar a forma de tutela das manifestações culturais que ainda não foram propagadas em larga escala, detidas por comunidades e povos indígenas identificáveis, com base na interpretação dos dispositivos atualmente em vigor no direito pátrio. A partir desse levantamento e análise, esta dissertação tem como objetivo responder três perguntas: Há proteção do patrimônio cultural imaterial detido por comunidades tradicionais, conferindo direitos a estas, ou suas manifestações pertencem ao domínio público? O patrimônio cultural imaterial é objeto do direito de autor? Existem direitos morais no patrimônio cultural imaterial?

Para tanto, importante analisar como o patrimônio cultural imaterial é protegido no direito brasileiro. Assim, serão observadas as seguintes normas: (i) artigos 215, 216 e 231 da Constituição Federal; (ii) as convenções internacionais da Unesco, que já se encontram internalizadas no direito nacional, com força de lei ordinária, quais sejam: Convenção para a Salvaguarda do Patrimônio Cultural Imaterial ${ }^{5}$ e Declaração Universal sobre a Diversidade Cultural, ${ }^{6}$ Convenção relativa à Proteção do Patrimônio Mundial, Cultural e Natural; ${ }^{7}$ (iii) bem como a legislação aplicável aos direitos da

5 Essa Convenção estabelece, no art. X, que: “entende-se por patrimônio cultural imaterial as práticas, representações, expressões, conhecimentos e técnicas - junto com os instrumentos, objetos, artefatos e lugares culturais - que as comunidades, os grupos e, em alguns casos, os indivíduos reconhecem como parte integrante de seu patrimônio cultural".

6 Essa Declaração prevê, em seu art. X, que: "Toda criação tem suas origens nas tradições culturais, porém se desenvolve plenamente em contato com outras. Essa é a razão pelo qual o patrimônio, em todas as suas formas, deve ser preservado, valorizado e transmitido às gerações futuras como testemunho da experiência e das aspirações humanas, a fim de nutrir a criatividade em toda a sua diversidade e estabelecer um verdadeiro diálogo entre as culturas".

7 "Para fins da presente Convenção serão considerados como patrimônio cultural os lugares notáveis: obras do homem ou obras conjugadas do homem e da natureza, bem como as zonas, inclusive lugares arqueológicos, que tenham valor universal excepcional do ponto de vista histórico, estético, etnológico ou antropológico." 
personalidade e à propriedade intelectual, especialmente os direitos morais no direito de autor, ${ }^{8}$ que podem auxiliar nessa compreensão.

Para a resposta à primeira questão proposta será avaliado se os conhecimentos étnicos e tradicionais, que compõem o patrimônio cultural, estão protegidos pela Lei de Direitos Autorais n. ${ }^{\circ}$ 9.610, de 19 de fevereiro de 1998 (LDA), e se o patrimônio cultural imaterial é obra sujeita a cair em domínio público. Em especial, é importante analisar a Portaria n. ${ }^{\circ} 177$ da Funai, que prevê que aquele índio que cria obras estéticas não é o titular dos seus direitos autorais, mas sim a comunidade. Entretanto, se a obra é inovadora, ainda que feita com base nas tradições da comunidade, a titularidade é exclusivamente do índio que a fez. Esse entendimento merece ser examinado e questionado, sob pena de violar a LDA e os direitos do indivíduo autor da obra, ainda que possa existir o direito coletivo ínsito à obra, pois a criação individual, mesmo que inovadora, só é possível graças ao patrimônio imaterial coletivo no qual se inspira.

Esta pesquisa pretende abordar e expor no Capítulo 2 a legislação existente no âmbito nacional a respeito de patrimônio cultural imaterial, buscando identificar os direitos e deveres para uso e proteção desse patrimônio. Será analisado, também, o conceito jurídico de patrimônio cultural imaterial, verificando as fontes de direito que permitem tal definição, destacando o conceito constitucional, bem como o previsto nas normas infraconstitucionais. Por esse motivo, também serão apresentados os conceitos de cultura e de patrimônio cultural material, em sua concepção histórica, e a conceituação trazida pelo campo antropológico. ${ }^{9}$

Dessa análise será possível observar que o conceito de patrimônio cultural é tão amplo que compreende tanto aquelas manifestações culturais difundidas em nossa cultura em âmbito nacional, tais como o carnaval, o consumo do queijo tipo Minas, a festa junina, quanto as manifestações culturais propagadas apenas em

8 Ressalte-se que a Lei de Direitos Autorais nada fala sobre direito coletivo de imagem ou autoral, mas alguns doutrinadores sustentam que ela ressalva a proteção aos conhecimentos étnicos e tradicionais daqueles que podem cair no domínio público, estariam dizendo que tais conhecimentos são protegidos por ela mesma.

9 MARCHESAN, Ana Maria Moreira. A tutela do patrimônio cultural sob o enfoque do direito ambiental. Porto Alegre: Livraria do Advogado, 2007. p. X. 
proporções regionais, como os banhos de cheiro na região Norte, ${ }^{10}$ a dança paraense do carimbó, ${ }^{11}$ e, por fim, as manifestações culturais que ainda se encontram protegidas, espalhadas apenas no seio das comunidades tradicionais e povos indígenas, tais como os conhecimentos que as comunidades Guariba e Mutamba, das etnias indígenas Macuxi e Wapixana, possuem sobre o modo de utilizar a palha da palmeira de buriti para cobertura das malocas e elaboração de saias para a dança festiva tradicional denominada Parichara, ${ }^{12}$ ou a lenda de determinado povo indígena ou o conhecimento sobre como preparar utensílios para realizar pinturas corporais ou para tocar músicas, como parte de rituais sagrados e muitos outros.

A partir dessa percepção, de que o conceito de patrimônio cultural compreende tanto aquelas manifestações culturais difundidas por todo o território nacional quanto aquelas manifestações regionais e, em especial, as detidas por comunidades e povos tradicionais de forma individualizada, que ainda não foram propagadas e compreendem suas crenças, valores e inclusive seus rituais sagrados, consegue-se dimensionar a complexidade da definição desse conceito e, particularmente, da aplicação das disposições legais sobre o patrimônio cultural ao caso concreto.

Justamente por isso o presente estudo avaliará e buscará responder aos três questionamentos acima no tocante, apenas, ao patrimônio cultural imaterial não difundido e detido por comunidades ou povos tradicionais identificáveis. Assim, não será objeto desta pesquisa a manifestação cultural que integra o patrimônio cultural

10 BARATA, Lauro E. S. A economia verde: Amazônia. Ciência e Cultura, São Paulo, v. 64, n. 3, p. 31-35, 2012. Disponível em: <http://cienciaecultura.bvs.br/scielo.php?script=sci_arttext\& pid=S0009-67252012000300011\&lng=en\&nrm=iso $>$. Acesso em: 16 abr. 2013.

11 O carimbó nas mesorregiões nordeste paraense, metropolitana de Belém e Marajó está em processo de registro como Patrimônio Cultural do Brasil perante o IPHAN, e o dossiê preparado por esse órgão foi inclusive disponibilizado para consulta pública entre 18.02.2014 a 18.03.2014. Disponível em:

$<$ http://portal.iphan.gov.br/portal/montarDetalheConteudo.do?id=18359\&sigla=Noticia\&retorno=det alheNoticia>. Acesso em: 17 abr. 2014.

12 HADA, Aleksander Ribeiro. O Buriti (Mauritia flexuosa L. f.) na terra indígena Araçá, Roraima: usos tradicionais, manejo e potencial produtivo. 2010. Dissertação (Mestrado) - INPA, Manaus, p. 41-42. Disponível em: <http://www.bibliotecaflorestal.ufv.br/bitstream/handle/123456789/4275/ dissertacao_Aleksander\%20Hada\%20Ribeiro.pdf?sequence=1>. Acesso em: 17 abr. 2014. 
imaterial e que esteja em domínio público ou que já esteja de tal forma difundida na sociedade brasileira ou internacional que se torna impossível a identificação da sua origem e titularidade. Também não será objeto deste trabalho a análise do patrimônio cultural em geral, e, portanto, não serão abordadas as legislações sobre patrimônio cultural material ou relacionadas a tombamento. Por fim, não integra o objetivo do presente trabalho o estudo dos direitos da sociedade de acesso à cultura, focando a pesquisa apenas nos direitos que grupos identificáveis, que desenvolvem e preservam suas manifestações culturais imateriais, possuem quanto a estas.

Em seguida, no Capítulo 3 passar-se-á à análise da legislação relativa à propriedade intelectual e aos direitos da personalidade, especialmente direitos morais e o direito de autor, a fim de identificar a existência de direitos que podem ser aplicáveis ao patrimônio cultural imaterial detido por comunidades tradicionais e indígenas, observando, inclusive, se o arcabouço legal desses institutos complementa-se ou se coexiste de forma independente. A análise da legislação sobre direitos da personalidade, especialmente direitos morais e de autor, não estará focada apenas no estudo dos direitos individuais de seus titulares, mas também será realizada com o intuito de avaliar se o direito de autor se aplica à tutela do patrimônio cultural imaterial e se existem direitos morais de autor - direito da personalidade - a comunidades tradicionais ou indígenas. Pretende, em realidade, tratar do patrimônio cultural imaterial gerado e desenvolvido por comunidades tradicionais ou indígenas, passíveis de identificação ainda que não possível a individualização -, que desperta interesse da sociedade, inclusive para fins comerciais e de apropriação privada. ${ }^{13}$

Este trabalho não possui a ambição de esgotar a análise a respeito do conceito de propriedade intelectual e de direitos de autor, e tais conceitos serão apresentados na medida necessária para a compreensão dos institutos, avaliação da possibilidade de aplicação do direito de autor para a tutela do patrimônio cultural imaterial. Será dada ênfase aos direitos morais a fim de se identificar se eles são aplicáveis à tutela das manifestações culturais de comunidades tradicionais ou

\footnotetext{
13 MILEO, Bruno Alberto P.; SOARES, Gysele A. A cultura tradicional e o direito autoral. In: SEMINÁRIO PATRIMÔNIO CULTURAL E PROPRIEDADE INTELECTUAL: PROTEÇÃO DO CONHECIMENTO E DAS EXPRESSÕES CULTURAIS TRADICIONAIS. Anais... Belém, 1315.10.2004. Organizado por Eliane Moreira, Carla Arouca Belas, Benedita Barros, Antônio Pinheiro. Belém: Cesupa/MPEG, 2005. p. 182.
} 
indígenas. Não serão objeto deste estudo os direitos patrimoniais, porém isso não nos impedirá de mencioná-lo em caráter de exceção sempre que necessário. Nesse aspecto, importante ressalvar que adotaremos o emprego das expressões direito de autor, para tratar dos direitos morais e patrimoniais do criador da obra, e direito autoral, para se referir ao ramo autônomo, que inclui os direitos do criador e os direitos conexos. ${ }^{14}$

O propósito do presente trabalho, portanto, é identificar, a partir das normas aplicáveis à tutela do patrimônio cultural imaterial, se existem direitos incidentes sobre as manifestações culturais imateriais, especialmente os morais, detidos pelos povos indígenas, afro-brasileiros e por outros grupos participantes do processo civilizatório nacional, dado que a Constituição Federal ${ }^{15}$ garante a esses grupos a proteção de suas manifestações culturais. Ressalte-se que, no tocante a povos indígenas, este trabalho possui como objetivo tratar do patrimônio cultural imaterial e da interpretação da legislação vigente conforme à Constituição. ${ }^{16}$ Assim, serão consideradas as manifestações culturais em sentido amplo, contemplando as manifestações de autoria desconhecida e aquelas de povos e comunidades tradicionais identificáveis, inclusive dos povos indígenas. Contudo, não é objeto do presente trabalho a análise da legislação aplicável especificamente aos povos indígenas, tampouco especificamente da Convenção n. ${ }^{\circ} 169$ da Organização Internacional do Trabalho (OIT) - embora ela possa ser citada caso seja pertinente para os fins pretendidos deste estudo -, ou a questão de demarcação de terras e usufruto delas, de tal forma que o exame dos direitos culturais dos povos indígenas será realizado com o mesmo enfoque dado aos direitos culturais dos demais povos e comunidades tradicionais.

\footnotetext{
CHINELLATO, Silmara Juny de Abreu. Direito de autor e direitos da personalidade: reflexões à luz do Código Civil. 2008. Tese (Concurso de Professor Titular de Direito Civil) - Faculdade de Direito da Universidade de São Paulo, São Paulo, p.16.

15 Conforme dispõem os artigos 215 e $216 \mathrm{da} \mathrm{CF}$.

16 De acordo com Virgílio Afonso da Silva, "quando se fala em interpretação conforme a constituição, quer-se com isso dizer que, quando há mais de uma interpretação possível para um dispositivo legal, deve ser dada preferência aquela que seja conforme a constituição" (SILVA, Virgílio Afonso da. Interpretação conforme a constituição: entre a trivialidade e a centralização judicial. Revista DireitoGV, São Paulo, v. 2, n. 1, p. 193, jan.-jun. 2006).
} 
No Capítulo 4 será apresentada a interpretação conforme dos dispositivos que tratam da proteção ao patrimônio cultural imaterial com a Constituição Federal, bem como as principais dificuldades para enquadramento da proteção a este patrimônio cultural imaterial no escopo do direito de autor, para, a seguir, analisar se existem direitos e obrigações a serem seguidos para uso das manifestações culturais de comunidades ou povos tradicionais vivos e identificáveis, ${ }^{17}$ como resultado da interpretação conforme das convenções Unesco e LDA com a Constituição Federal.

Por fim, no Capítulo 5 será avaliado o projeto de lei já desenvolvido para regular as manifestações culturais imateriais, ainda que a tramitação desse projeto tenha sido arquivada, e será apresentada proposta de norma para regulamentar o patrimônio cultural imaterial, incorporando os princípios, direitos e obrigações identificados nesta dissertação de mestrado.

Apresentada a estrutura deste trabalho, ressalta-se sua importância, considerando que o Brasil é um país de destacada diversidade florestal e cultural e que tanto o marco legal destinado à proteção da biodiversidade nacional ${ }^{18}$ como aquele destinado a promover a conservação, uso e divulgação da cultura nacional, ${ }^{19}$ expressada por meio do patrimônio cultural imaterial, não vêm sendo interpretados e aplicados em conformidade com a Constituição. Assim, necessário o aprofundamento nos estudos do marco legal hoje em vigor, a fim de que se verifique se, a partir de interpretação sistêmica das normas existentes, é possível identificar os direitos e deveres atrelados ao patrimônio cultural imaterial já instituídos no Brasil pela legislação em vigor no território nacional, especialmente no tocante à tutela dos direitos morais das comunidades tradicionais e indígenas sobre seus bens culturais imateriais.

17 DRUMMOND, Victor Gameiro. A tutela jurídica das expressões culturais tradicionais. 2001. Tese (Mestrado) - Universidade de Lisboa, Faculdade de Direito, Lisboa, p. 59. No prelo.

18 Como é possível notar no site do Conselho de Gestão do Patrimônio Genético, o próprio Ministério do Meio Ambiente apresentou projeto de lei para substituir o marco legal atualmente em vigor, considerado insuficiente, a Medida Provisória 2.186-16/2001 (www.mma.gov.br/cgen).

19 O próprio IPHAN ajuizou no Supremo Tribunal Federal (STF) a Arguição de Descumprimento de Preceito Fundamental (ADPF) n. ${ }^{\circ}$ 206/2010, por entender que a interpretação jurisprudencial do artigo $1 .^{\circ}$ do Decreto-lei n. ${ }^{\circ}$ 25/1937, que organiza a proteção do Patrimônio Histórico e Artístico Nacional, está em desconformidade com a Constituição Federal de 1988. 


\section{Capítulo 2 \\ O PATRIMÔNIO CULTURAL IMATERIAL}

Neste capítulo será apresentado o conceito de patrimônio cultural imaterial, ressaltando que o conceito de patrimônio utilizado nessa terminologia não deve ser interpretado de acordo com aquele adotado no direito civil, na acepção de propriedade. ${ }^{20}$ Ainda será exposto o conceito de patrimônio cultural e de direitos culturais, dentre os quais se enquadra o conceito de fontes de cultura e do próprio patrimônio cultural. ${ }^{21}$ Contudo, para a melhor compreensão dessa definição, necessário, primeiramente, entender o significado de cultura. Cultura pode ser analisada sob diversos aspectos. Inicialmente, o conceito constante do dicionário da língua portuguesa indica que cultura é "o conhecimento acumulado pela humanidade através das gerações". ${ }^{22}$

De acordo com a concepção antropológica, Manuela Carneiro da Cunha define que cultura relaciona-se com "noção de alguma qualidade original, um espírito ou essência que aglutinaria as pessoas em nações e separaria as nações umas das outras" ${ }^{\text {23 }}$. Para Luiz Gonzaga Mello sustenta que cultura pode ser entendida como o "conjunto complexo que inclui conhecimento, crença, arte, moral, lei, costumes e várias outras aptidões e hábitos adquiridos pelo homem como membro de uma sociedade", ${ }^{24}$ ou seja, seria todo o universo de obras criadas pelo homem, sendo seu principal diferencial dos demais animais, ${ }^{25}$ pois, embora o desenvolvimento de um bebê humano

\footnotetext{
20 A propriedade pode ser definida como a relação entre um indivíduo e um sujeito passivo universal, cabendo a toda a sociedade o dever de respeitar o direito que o indivíduo possui de usar, gozar e dispor dos bens sob sua propriedade. Cf. SILVA, José Afonso da. Comentário contextual à Constituição. 7. ed. São Paulo: Malheiros, 2010. p. 119.

21 REISEWITZ, Lúcia. Direito ambiental e patrimônio cultural: direito à preservação da memória, ação e identidade do povo brasileiro. São Paulo: Juarez de Oliveira, 2004. p. 77-80.

22 ACADEMIA BRASILEIRA DE LETRAS. Dicionário escolar da lingua portuguesa. 2. ed. São Paulo: Nacional, 2008. p. 384.

23 CUNHA, Manoela Carneiro da. Cultura com aspas e outros ensaios. São Paulo: Cosacnayf. 2009, p. 356-357.

24 MELLO, Luiz Gonzaga de. Antropologia cultural: iniciação, teoria e temas. 13. ed. Rio de Janeiro: Vozes, 2007. p. 40.

25 Cf. LARAIA, Roque de Barros. Cultura: um conceito antropológico. 20. ed. Rio de Janeiro: Jorge Zahar, 2006. p. 51; e MELLO, Luiz Gonzaga de. Antropologia cultural: iniciação, teoria e temas. 19. ed. Rio de Janeiro: Vozes, 2011. p. 41.
} 
e o de um bebê chimpanzé sejam muito parecidos no primeiro ano de vida, ${ }^{26}$ a partir do momento em que o bebê humano começa a falar, a diferença de aprendizado e de desenvolvimento entre ambos torna-se gritante. Tal circunstância se deve, em muito, ao fato de que, a partir da comunicação oral, é possível ensinar e transmitir ao bebê humano todo o conhecimento acumulado de seus pais e da sociedade em que vive, enquanto as experiências do bebê chimpanzé não são compartilhadas e decorrem exclusivamente de seu aprendizado. ${ }^{27}$

Ora, isso nada mais é do que a transmissão oral da cultura, prática essencial ao desenvolvimento humano e à criação e transmissão do patrimônio cultural imaterial, como se verá adiante neste trabalho. Já para Christoph Brumann a definição de cultura seria mais ampla e consistiria no "conjunto de padrões adquiridos socialmente a partir dos quais as pessoas pensam, sentem e fazem. [...] Mesmo ver, ouvir e ler uns aos outros pode ser o suficiente", ${ }^{28}$ e, de acordo com essa concepção, o sentimento e o pensamento integram a cultura. A Unesco, também com uma concepção mais ampla desse conceito, define cultura como:

O conjunto dos traços distintivos espirituais e materiais, intelectuais e afetivos que caracterizam uma sociedade ou um grupo social e que abrange, além das artes e das letras, os modos de vida, as maneiras de viver juntos, os sistemas de valores, as tradições e as crenças. ${ }^{29}$

Dessa forma, verifica-se que a cultura não é um patrimônio estático, mas, sim, um patrimônio em constante mutação e reconstrução. A cultura se renova com as relações humanas e também com as relações entre homem e natureza, que é um dos principais meios em que a cultura se expressa, servindo como tela para a projeção das manifestações culturais do homem de acordo com o ambiente e época em que vive. ${ }^{30}$ Constata-se, portanto, que a cultura reúne os saberes e os comportamentos acumulados

26 Cf. LARAIA, Roque de Barros. Ibidem, p. 51.

LARAIA, Roque de Barros. Cultura: um conceito antropológico. 14. ed. Rio de Janeiro: Jorge Zahar, 2001. p. 40-46. Current Anthropology, v. 40, Supplement, p. 23, 1999.

29 UNESCO, Declaração Universal sobre a Diversidade Cultural, 2002. Preâmbulo.

30 MORAIS, Regis de. Estudos de filosofia da cultura. São Paulo: Loyola, 1992. p. 31. 
em uma sociedade e se presta tanto à formação da percepção humana quanto à manutenção de suas memórias para as presentes e futuras gerações.

Uma vez compreendido o conceito de cultura de acordo com as concepções da antropologia e da filosofia, ainda que todas essas conceituações contribuam para a compreensão do vernáculo, para a interpretação do termo cultura em conformidade com a Constituição Federal é necessário avaliar seu conceito na esfera jurídica. Assim, no âmbito jurídico, teria a cultura o mesmo significado daquele expresso nas definições acima tratadas?

De acordo com José Afonso da Silva, ${ }^{31}$ a acepção constitucional de cultura deve ser compreendida, primeiramente, em seu duplo sentido, qual seja cultura como normas jurídico-constitucionais - ou seja, as normas que estabelecem direitos relativos à cultura ${ }^{32}$ - e o próprio objeto normatizado, por exemplo, a cultura e o patrimônio cultural em si e seus modos de fazer, viver e criar, suas manifestações artísticas, objetos, sítios urbanos e monumentos de valor cultural, que permitem a identidade e a memória dos grupos formadores da sociedade brasileira.

Importante ainda notar que a Constituição tutela a cultura relacionada ao processo civilizatório nacional e, portanto, não é toda e qualquer manifestação cultural do dia a dia que certamente decorreu da cultura nos termos definidos pela antropologia, que será objeto da tutela constitucional, mas somente aquela expressão cultural que se relaciona com a identidade e a memória dos grupos formadores da sociedade brasileira e com as ações, isto é, práticas adotadas por esses grupos durante tal processo de formação.

José Afonso da Silva, ${ }^{33}$ inclusive, apresenta exemplo de que, embora um garfo, uma colher ou uma espada possam incluir-se no sentido de cultura da

\footnotetext{
31 SILVA, José Afonso da. Comentário contextual à Constituição. 7. ed. São Paulo: Malheiros, 2010. p. 821 .

32 Como, por exemplo, os direitos culturais ao acesso à cultura, à valorização, difusão e proteção da manifestação cultural, liberdade de criação, igualdade de direitos para uso dos bens culturais.

33 SILVA, José Afonso da. Comentário contextual à Constituição. 7. ed. São Paulo: Malheiros, 2010. p. 821 .
} 
antropologia, tais utensílios somente terão significado no âmbito constitucional se possuírem relação com personagens históricos importantes dos grupos formadores da sociedade brasileira. Dessa maneira, para os fins do presente estudo serão consideradas integrantes do conceito de cultura adotado pela Constituição Federal as manifestações culturais de povos e comunidades tradicionais, pois estes contribuíram e vêm contribuindo para o processo civilizatório nacional. Ressalte-se que a expressão "processo civilizatório nacional" não deve ser interpretada sob o manto do evolucionismo unilinear, ${ }^{34}$ i.e., como se as comunidades ou grupos tradicionais fossem considerados primitivos em uma escala evolutiva e que deveriam passar por diversos estágios para culminar em uma sociedade mais evoluída, dado que para os fins deste trabalho não deve ser entendido que o processo civilizatório consiste em etapas a serem ultrapassadas pelas sociedades conforme evoluem e se aprimoram, mas sim como um processo em que se protege a diversidade das sociedades e grupos.

Assim, as comunidades que contribuem para o processo civilizatório e que podem ser titulares de direitos sobre o patrimônio cultural imaterial que criaram são todos os grupos ou comunidades que se organizam e se identificam como tal, de forma coletiva, e que, independentemente de sua forma de organização ou atuação, devem ser entendidas como contribuintes para a construção da cultura nacional, sem que se considere um grupo como menos evoluído ou desenvolvido que outros. Uma vez compreendido o conceito de cultura, passa-se à análise do conceito de patrimônio cultural e, finalmente, de patrimônio cultural imaterial.

\subsection{Proteção ao patrimônio cultural no Brasil}

As primeiras manifestações de reconhecimento de um patrimônio cultural no Brasil, e do interesse da sociedade em protegê-lo, ocorreram para fins de proteção de patrimônios materiais, normalmente construções, fossem monumentos, edifícios ou estátuas. Assim, a primeira ${ }^{35}$ evidência de que se tem conhecimento sobre a

\footnotetext{
34 BARBOSA, Marco Antonio. Autodeterminação: direito à diferença. São Paulo: Plêiade; Fapesp, 2001. p. 114-124.

35 BRASIL. Ministério da Educação e Cultura. Proteção e revitalização do patrimônio cultural no Brasil: uma trajetória. Brasília: Secretaria do Patrimônio Histórico e Artístico Nacional e Fundação Nacional Pró-Memória, 1980. p. 9; MARCHESAN, Ana Maria Moreira. A tutela do patrimônio
} 
intenção de proteger um patrimônio cultural nacional ocorreu no Brasil Império, em 5 de abril de 1742, quando o então Vice-Rei do Brasil escreveu ao Governador de Pernambuco determinando o fim das obras que buscavam transformar o Palácio das Duas Torres, construído por Mauricio de Nassau, em quartel. ${ }^{36}$ No ordenamento jurídico brasileiro, em 1830, foi inserido no Código Criminal do Império o artigo 178, prevendo a tipificação da conduta de "destruir, abater, mutilar ou danificar monumentos, edifícios, bens públicos ou quaisquer outros objetos destinados à utilidade, decoração ou recreio público". Veja-se que, embora o objetivo fosse a proteção dos monumentos, não havia o reconhecimento da existência de bens culturais, tampouco de um patrimônio cultural. Após essa norma, foram necessários quase cem anos para que o tema voltasse a apresentar evoluções na seara jurídica.

Assim como no Brasil, em âmbito internacional também não se observava evolução na regulamentação do patrimônio cultural, e só a partir do século XX é que novos diplomas legais vieram tratar de sua proteção, ${ }^{37}$ especialmente em função da Lei italiana n. ${ }^{0} 185$, de 12 de junho de 1902, da Lei francesa sobre os monumentos históricos, de 31 de dezembro de 1913, e do Decreto-lei espanhol de 1926, embora todos tratassem prioritariamente da proteção aos bens materiais. No Brasil, a partir de 1920, ocorreram diversos movimentos para a elaboração de anteprojetos de lei, visando regular o patrimônio cultural, mas sempre de forma isolada ou para tutelar somente o patrimônio arqueológico ${ }^{38}$ ou os monumentos artísticos. ${ }^{39}$ A primeira norma que tratou expressamente do patrimônio artístico foi o Decreto n. ${ }^{\circ} 22.928$ de 1933, que reconheceu a cidade de Ouro Preto como monumento nacional, em função de sua importância histórica para a formação de noção de nacionalidade e a consequente

cultural sob o enfoque do direito ambiental. Porto Alegre: Livraria do Advogado, 2007. p. 50; e MIRANDA, Marcos Paulo de Souza. Tutela do patrimônio cultural brasileiro. Belo Horizonte: Del Rey, 2006. p. 1.

BRASIL. Ministério da Educação e Cultura. Proteção e revitalização do patrimônio cultural no Brasil: uma trajetória. Brasília, DF, Secretaria do Patrimônio Histórico e Artístico Nacional, Fundação Nacional Pró-Memória. 1980. p. 61. Disponível em: <portal.iphan.gov.br/portal/baixaFcdAnexo.do?id=531>. Acesso em: 7 jul. 2012.

37 RODRIGUES, José Eduardo Ramos. O patrimônio cultural nos documentos Internacionais. In: DERANI, Cristiane; COSTA, José Augusto Fontoura (Org.). Direito ambiental internacional. Santos: Universitária, 2001. p. 200.

38 Projeto elaborado por Alberto Childe. Cf. MIRANDA, Marcos Paulo de Souza. Tutela do patrimônio cultural brasileiro. Belo Horizonte: Del Rey, 2006. p. 1.

39 Projeto elaborado pelo Deputado Luiz Cedro. Cf. MIRANDA, Marcos Paulo de Souza. Ibidem, p. 1. 
necessidade de conservação desse patrimônio artístico da nação, reconhecendo tal aspecto como dever do poder público.

Assim, embora essa norma dispusesse apenas sobre o reconhecimento de uma cidade ao status de monumento nacional, trouxe conceitos importantes ao ordenamento jurídico nacional e para a regulação do patrimônio cultural, reconhecendo a existência de um patrimônio artístico da nação, bem como o dever de o poder público defendê-lo, evidenciando que os bens culturais a serem tutelados precisariam ter relevância histórica na formação da concepção de nacionalidade. No ano seguinte, a Constituição Federal, de 16 de julho de 1934, passou a prever a proteção ao patrimônio cultural, disciplinando em seu artigo 10, III, que caberia à União e aos Estados, de forma concorrente, a proteção das "belezas naturais e monumentos de valores históricos ou artísticos, podendo impedir a evasão de obra de arte". E, ainda, em seu Título V, que tratava da família, educação e cultura, previa que caberia à "União, Estados e Municípios favorecer e animar o desenvolvimento das ciências, das artes, das letras e cultura em geral, proteger os objetos de interesse histórico e o patrimônio artístico do país". 40

Por fim, ao instituir a função social da propriedade, previu em seu artigo 134 que os monumentos históricos, artísticos e naturais, bem como as paisagens ou locais dotados de notória beleza pela natureza, passam a ter proteção e cuidados especiais da União, Estados e Municípios, dispondo, inclusive, que quaisquer atentados cometidos contra tais monumentos seriam considerados como realizados contra o patrimônio nacional. Com esses dispositivos constitucionais, o patrimônio cultural passa a ter proteção no direito nacional, ainda que de forma mais restrita e atrelada aos bens materiais.

Em 1937, foi criado, por meio da Lei federal n. ${ }^{\circ}$ 378, de 13 de janeiro, o Serviço do Patrimônio Histórico e Artístico Nacional com a finalidade de realizar o tombamento, a conservação e a divulgação de tal patrimônio. Nesse mesmo ano, foi apresentado projeto de lei para proteção do patrimônio artístico e cultural ao Senado,

40 MARCHESAN, Ana Maria Moreira. A tutela do patrimônio cultural sob o enfoque do direito ambiental. Porto Alegre: Livraria do Advogado, 2007. p. 51. 
recebendo aprovação e retornando à Câmara para discussão final, quando, em 10 de novembro de 1937, ocorreu o golpe de Estado que dissolveu o Congresso e promoveu a entrada em vigor de nova Constituição Federal, que mesmo assim garantia proteções ao patrimônio cultural nacional, semelhantes ao disposto na Constituição de 1934.

E assim o Estado Novo editou o Decreto-lei n. ${ }^{\circ}$ 25, de 30 de novembro de $1937,{ }^{41}$ que permanece em vigor até os dias atuais, para regulamentar o dispositivo constitucional, e tal norma reproduzia em grande parte o conteúdo do projeto de lei que estava em tramitação por ocasião do golpe. Em tal norma o patrimônio cultural era denominado patrimônio histórico e artístico nacional, sendo definido como:

O conjunto dos bens móveis e imóveis existentes no país e cuja conservação seja de interesse público, quer por sua vinculação a fatos memoráveis da história do Brasil, quer por seu excepcional valor arqueológico ou etnográfico, bibliográfico ou artístico.

Tal norma ainda previa que os monumentos naturais, sítios e paisagens de feição notável também poderiam se submeter ao tombamento. Contudo, era condição para que determinada manifestação cultural se enquadrasse como patrimônio histórico ou artístico nacional sua inscrição em um dos quatro Livros de Tombo junto ao órgão então competente, Serviço do Patrimônio Histórico e Artístico Nacional, que à época não possuía nenhum livro para registro das manifestações culturais imateriais, prevendo apenas um livro para inscrição das manifestações artísticas aplicadas, ou seja, materializadas.

Em 1942, o Supremo Tribunal Federal analisou a legalidade de determinado ato de tombamento federal, bem como a constitucionalidade do Decreto-lei então em vigor, concluindo que eram constitucionais as disposições do Decreto-lei, sendo cabível a desapropriação, ainda que restrinja direitos do proprietário, para fins de promoção do interesse público de conservar monumentos e objetos relevantes para a sociedade, reconhecendo a função social dos bens culturais. ${ }^{42}$ Inclusive, tal acórdão

\footnotetext{
41 Disponível em: <http://www.planalto.gov.br/ccivil_03/decreto-lei/del0025.htm>. Acesso em: 23 nov. 2011.

42 Publicado em Revista dos Tribunais, n. 524, p. 785-811, 1942.
} 
apresenta importante ensinamento sobre o conceito de propriedade social, que seria fundamento para a legalidade da proteção aos monumentos históricos, bem como indicativo de que a propriedade seria cada vez menos individual. Ainda, tal acórdão apresenta o entendimento de que os bens e objetos culturais seriam compostos por dois aspectos distintos: a vertente intelectual, ou seja, a ideia, o pensamento e a criatividade do artista; e a vertente material, qual seja a expressão dessa ideia em um corpo, um objeto ou edifício, que corporifica o aspecto intelectual. E, de acordo com tal julgado, o aspecto intelectual da obra cultural pertenceria à sociedade, enquanto o material, à propriedade privada, gravada de servidão.

Relevante considerar tal entendimento, sustentado em 1942, de que o aspecto intelectual dos bens culturais pertenceria à sociedade, para os fins pretendidos pelo presente trabalho, que busca exatamente identificar se existem direitos morais nessas manifestações culturais e em seu processo criativo, ou se estas pertencem ao domínio público. Em continuidade à análise da regulamentação legal do patrimônio cultural no Brasil, observa-se, com a Constituição do Estado Novo, um retrocesso no tratamento ao tema, dado que o Texto Constitucional somente previu que competia ao Poder Público proteger os bens culturais, ${ }^{43}$ retirando a previsão de que as ofensas a estes seriam equiparadas a crime contra o patrimônio nacional. Ainda na vigência dessa Carta Constitucional, passou a haver a tutela do patrimônio arqueológico, por meio da Lei n. ${ }^{\circ}$ 3.924, de 26 de junho de 1961. A Constituição de 1967 manteve praticamente o mesmo texto dos artigos que tratavam do patrimônio cultural na Constituição de 1946, mantendo, inclusive, o tema sob o título "Da família, da educação e da cultura". Na Emenda de 1969, o tema passou a ser regulamentado por artigo único, mas conservou os mesmos preceitos e era tratado sob o mesmo título.

Com o advento da Constituição de 1988, criou-se uma nova concepção de patrimônio cultural, que passou a tratar não apenas do patrimônio cultural material, mas também do imaterial. Para Carlos Frederico Marés, ${ }^{44}$ o aspecto mais inovador do

Assim definidos à época, por meio do artigo 178, como: "as obras, monumento e documentos de valor histórico e artístico, bem como os monumentos naturais, as paisagens e os locais dotados de particular beleza ficam sob proteção do poder público".

44 MARÉS, Carlos Frederico. A proteção jurídica dos bens culturais. Cadernos de Direito Constitucional e Ciência Política, São Paulo, n. 2, p. 19, 1993. 
novo texto constitucional é o fato de vincular a proteção não a qualquer tipo de bem cultural, mas somente àqueles que se relacionam com a identidade, ação e memória dos grupos formadores do processo civilizatório nacional. Isso porque, se até então a diversidade cultural não era prestigiada em nosso país, a partir do Texto Constitucional de 1988 passou-se a promover, difundir e proteger a manifestação cultural de grupos indígenas, afro-brasileiros e outros que contribuem para a formação da sociedade, sendo, portanto, estabelecidos direitos relacionados ao patrimônio cultural imaterial, os quais serão identificados adiante.

\subsection{Conceito de patrimônio cultural}

Em 1988, a Constituição Federal trouxe a atual conceituação de patrimônio cultural brasileiro, definindo quais bens o compõem, de forma bastante ampla, bem como garantindo constitucionalmente o pleno exercício dos direitos culturais e o acesso às fontes da cultura nacional, apoiando e incentivando a valorização e a difusão das manifestações culturais. ${ }^{45}$ Será analisado primeiramente o artigo 216 da Constituição, que define o conceito de patrimônio cultural brasileiro e, em seguida, o artigo 215, que estabelece obrigações ao Estado e garante direitos culturais.

Um primeiro aspecto a ser considerado é que a Constituição optou por adotar a terminologia "patrimônio cultural brasileiro", em vez de "patrimônio histórico e artístico", até então empregado pelas normas nacionais. A expressão escolhida em 1988 é mais abrangente e adequada por incluir não apenas o patrimônio histórico e artístico, mas também as demais expressões culturais que não são históricas ou artísticas, porém se relacionam à identidade e à memória de um grupo, tais como as manifestações associadas ao seu modo de viver. Ainda, como sustenta José Afonso da Silva, a expressão patrimônio cultural brasileiro se refere à manifestação cultural no âmbito federal, mas também no estadual, municipal ${ }^{46} \mathrm{e}$, ainda, de acordo com os termos da Constituição, inclui aquelas manifestações culturais que persistem apenas no âmbito dos grupos que contribuem para o processo civilizatório nacional.

\footnotetext{
45 Conforme disposto nos artigos 215 e 216 da Constituição Federal.

46 SILVA, José Afonso da. Comentário contextual à Constituição. 7. ed. São Paulo: Malheiros, 2010. p. 827.
} 
De acordo com a Constituição, para caracterização dos bens integrantes do patrimônio cultural, estes devem ser portadores de referências à identidade, ação e memória dos grupos formadores da sociedade, o que significa que não serão todos os bens que receberão a tutela sob o conceito de patrimônio cultural, mas somente aqueles que sejam referenciais para garantir a identidade e a memória, ou seja, que possam promover a partir do passado uma relação enriquecedora para o presente ${ }^{47}$ e garantir a diversidade cultural, bem jurídico que passou a ser protegido pela Constituição.

Ainda, o artigo 216 da Constituição dispõe que o patrimônio cultural brasileiro pode ser constituído por bens de natureza material, isto é, corpóreos, e imaterial, incorpóreos ou intangíveis, expressão provinda da língua inglesa (intangible) e adotada pela United Nations Educational, Scientific and Cultural Organization (Unesco). Importante destacar que determinados bens culturais podem se expressar ora de forma imaterial, ora material. ${ }^{48}$ De todas as maneiras, a Constituição é clara em garantir ambas as formas de expressão da cultura. Assim, o bem cultural material pode ser entendido como a expressão cultural em um veículo corpóreo, corpus, e inclui aqueles instrumentos confeccionados pelo homem para a execução de seus modos de fazer, viver e criar, consistindo em artefatos, por exemplo, para caça, instrumentos, inclusive os musicais, edificações, artesanato, cerâmicas, pinturas, desenhos etc., além de estátuas ou outros bens públicos culturais, inclusive os bens de valor paisagístico.

Por outro lado, o bem imaterial caracteriza-se por ser a expressão cultural transmitida por meio da cultura oral de geração a geração, ${ }^{49}$ que não pode ser corporificada ou tocada, ${ }^{50}$ ainda que possa, em muitas situações, ser expressada por meios físicos e corpóreos. Portanto, de acordo com Marcos Paulo de Souza Miranda, o bem imaterial é caracterizado pela relevância que a manifestação intelectual, própria do espírito humano, possui em relação ao suporte corpóreo que lhe dá expressão. Por

FURTADO, Celso. O capitalismo global. São Paulo: Paz e Terra, 1999. p. 72.

48 MIRANDA, Marcos Paulo de Souza. Tutela do patrimônio cultural brasileiro. Belo Horizonte: Del Rey, 2006. p. 56-58.

49 CARBONI, Guilherme. Direito autoral e autoria colaborativa: na economia da informação em rede. São Paulo: Quartier Latin, 2010. p. 23.

50 PELEGRINI, Sandra C. A.; FUNARI, Pedro Paulo. O que é o patrimônio cultural imaterial. São Paulo: Brasiliense, 2008. p. 27. 
conseguinte, na manifestação cultural imaterial a expressão intelectual possui maior destaque e importância do que seu suporte físico. ${ }^{51}$

Desse modo, em conformidade com o Texto Constitucional, ${ }^{52}$ incluemse como patrimônio cultural brasileiro, desde que se relacionem à identidade, ação e memória dos diversos grupos formadores da sociedade brasileira:

I - as formas de expressão;

II - os modos de criar, fazer e viver;

III - as criações científicas, artísticas e tecnológicas;

IV - as obras, objetos, documentos, edificações e demais espaços destinados às manifestações artístico-culturais;

$\mathrm{V}$ - os conjuntos urbanos e sítios de valor histórico, paisagístico, artístico, arqueológico, paleontológico, ecológico e científico.

Importante compreender que a lista supra é exemplificativa ${ }^{53} \mathrm{e}$, portanto, outros bens culturais podem ser tutelados pelo disposto na Constituição Federal, inclusive aquelas manifestações culturais artísticas que compõem os modos de criar, fazer e viver das comunidades, povos e grupos formadores da sociedade brasileira. Nesse momento, importante realizar um esclarecimento, pois o objetivo deste trabalho é analisar, especificamente, o patrimônio cultural imaterial, e, por esse motivo, não serão aprofundados os conceitos e regulamentações aplicáveis exclusivamente ao patrimônio cultural material, descritos nos incisos IV e $\mathrm{V}$ mencionados, especialmente aqueles relacionados ao tombamento, pois o tema já foi fartamente debatido na doutrina e detalhado pela legislação em vigor.

A esse respeito, destaca-se apenas que a tutela do patrimônio cultural material possui regulamentação no direito nacional ${ }^{54}$ e é realizada especialmente por meio do tombamento e dos atos de registro. Portanto, seguindo a definição de bens

51 MIRANDA, Marcos Paulo de Souza. Tutela do patrimônio cultural brasileiro. Belo Horizonte: Del Rey, 2006. p. 59.

52 Artigo 216 da Constituição Federal.

53 BULOS, Uadi Lammêgo. Curso de direito constitucional. 6. ed. rev. e atual. São Paulo: Saraiva, 2011. p. 1570.

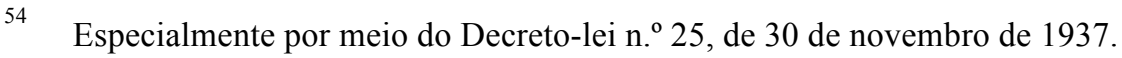


culturais imateriais, de acordo com o texto constitucional, conclui-se que podem ser conceituados como patrimônio cultural imaterial os modos de fazer, viver e criar dos grupos que contribuem para a formação da sociedade brasileira, assim como suas formas de expressão e suas criações artísticas, científicas e tecnológicas. Para José Afonso da Silva, as formas de expressão são as maneiras como se exterioriza a manifestação cultural, o que pode ocorrer por meio material ou imaterial. Seriam, portanto, as músicas, as línguas, a literatura, a dança, os rituais, as festas religiosas e o folclore. ${ }^{55}$ Quanto ao entendimento sobre o significado constitucional da expressão “modos de criar, de fazer e viver", José Afonso da Silva diz que essas são manifestações culturais populares que se perdem em função da industrialização da sociedade, ou seja, ainda que sejam criadas, desenvolvidas e preservadas pelos povos e comunidades tradicionais, tais manifestações culturais deixam de ser resguardadas pelos jovens, que migram das comunidades para as cidades, pois não recebem qualquer retribuição para investirem na conservação de sua biodiversidade.

Para Marcos Paulo de Souza Miranda, ${ }^{56}$ os modos de criar, fazer e são “os hábitos, os costumes e as tradições de nosso povo [...]. Dizem respeito à maneira como vivem os brasileiros, abrangendo sua culinária, agricultura, crenças costumes, hábitos, religião etc.”, podendo ser manifestações culturais materiais ou imateriais. Já as criações científicas, artísticas e tecnológicas são próprias da produção intelectual, claramente garantidas pela Constituição Federal em seu artigo 5. ${ }^{\circ}$, IX, e decorrem da liberdade de pensamento e da livre-iniciativa. Assim, as criações artísticas podem ser entendidas como a pintura, escultura, arquitetura, música, entre outros, enquanto as científicas e tecnológicas não possuem qualquer finalidade ou compromisso estético, mas sim com a solução de problemas técnicos. ${ }^{57}$

A partir dessa análise pormenorizada dos conceitos descritos no artigo 216, é possível ter uma dimensão mais precisa do conceito de bens culturais, especialmente os imateriais, que compõem o patrimônio cultural brasileiro. Assim, a

\footnotetext{
55 SILVA, José Afonso da. Comentário contextual à Constituição. 7. ed. São Paulo: Malheiros, 2010. p. 820-824.

56 MIRANDA, Marcos Paulo de Souza. Tutela do patrimônio cultural brasileiro. Belo Horizonte: Del Rey, 2006. p. 50-60.

57 SILVEIRA, Newton. Propriedade intelectual: propriedade industrial, direito de autor, software, cultivares, nome empresarial. 4. ed. rev. e ampl. Barueri: Manole, 2011. passim.
} 
definição de bens imateriais desenvolvida por Juliana Santilli congrega todos os elementos ora apresentados e permite a melhor compreensão dos bens imateriais que compõem o patrimônio cultural imaterial:

Os bens imateriais abrangem as mais diferentes formas de saber, fazer e criar, como músicas, contos, lendas, danças, receitas culinárias, técnicas artesanais e de manejo ambiental. Incluem ainda inovações e práticas culturais de povos indígenas, quilombolas e populações tradicionais que vão desde formas e técnicas de manejo de recursos naturais, até métodos de caça e pesca e conhecimentos sobre sistemas ecológicos e espécies com propriedades farmacêuticas, alimentícias e agrícolas, os conhecimentos tradicionais associados à biodiversidade. ${ }^{58}$

Além dos elementos suprarrelacionados, importante destacar que, nos termos da definição de patrimônio cultural imaterial constante do artigo $2 .^{\circ}$ da Convenção para Salvaguarda do Patrimônio Cultural Imaterial da Unesco, que será apresentada no item 2.5 a seguir, as línguas compõem o conceito de patrimônio cultural imaterial e, portanto, também devem ser entendidas como integrantes dos modos de fazer, viver e criar, nos termos previstos na Constituição Federal, especialmente porque a língua é instrumento de transmissão e conservação da cultura - transmitida de geração a geração pela tradição oral -, essencial para a perpetuidade das manifestações e diversidade cultural.

Por conseguinte, conclui-se que o patrimônio cultural imaterial é formado pelas expressões artísticas, científicas e tecnológicas, pelas línguas, os saberes relacionados à natureza, à fauna, flora, culinária, as danças, rituais, mitos, contos, histórias, músicas, poesias, pinturas etc., desenvolvidos pelos diversos grupos formadores da sociedade brasileira. A partir daí surge importante questão sobre quem são os grupos que desenvolvem esses patrimônios culturais, bem como qual a abrangência do patrimônio cultural produzido. A esse respeito, José Afonso da Silva, ao tratar do folclore, destaca que no Brasil, em função de sua extensão territorial, podem ser encontradas diversas manifestações culturais, podendo existir aquelas regionais, que

$58 \quad$ SANTILli, Juliana. In: MATHIAS, Fernando; NOVION, Henry de (Org.). As encruzilhadas das modernidades: debates sobre biodiversidade, tecnociência e cultura. São Paulo: Instituto Socioambiental, 2006. passim. 
são pouco difundidas, mas que ainda assim devem ser objeto de proteção, incentivo e difusão. ${ }^{59}$ Para Juliana Santilli, não apenas pode haver conhecimentos tradicionais regionais, que como será apresentado no capítulo seguinte integram o patrimônio cultural imaterial, como também aqueles detidos por uma comunidade tradicional ou por um grupo de comunidades ou um povo indígena que se dispersa para fora do território nacional. ${ }^{60}$

Constata-se que dentre as manifestações culturais que compõem o patrimônio cultural brasileiro existem aquelas que possuem expressão nacional e que, como tal, além de serem amplamente difundidas, não possuem titularidade definida, tendo sido desenvolvidas por pessoa ou grupo de pessoas não identificadas. São exemplos dessa modalidade de manifestação cultural de alcance nacional, integrante do patrimônio cultural, o carnaval, o uso do chá de camomila ou do suco de maracujá para acalmar, as músicas folclóricas, as festas juninas etc. Contudo, existem ainda as manifestações culturais que também se enquadram no conceito constitucional de patrimônio cultural, mas que possuem expressão regional, isto é, trata-se de manifestações da cultura daquela região que não possuem, ao menos ainda, grande expressão nacional e cuja titularidade também é desconhecida. São exemplos das manifestações culturais regionais, que integram o patrimônio cultural imaterial, a lenda do boto, na região amazônica, ${ }^{61}$ a música carimbó, difundida no Estado do Pará, ${ }^{62}$ a prática de consumo do chimarrão no Rio Grande do $\mathrm{Sul}^{63}$ etc.

Existem, ainda, as manifestações culturais de expressão local, isto é, criadas e detidas por um grupo de pessoas, por determinado povo indígena, por comunidades tradicionais. Essa modalidade de manifestação cultural, que também integra o patrimônio cultural, possui característica sui generis, na medida em que seu conteúdo envolve criações artísticas muito semelhantes às obras tuteladas pelo direito

59 SILVA, José Afonso da. Comentário contextual à Constituição. 7. ed. São Paulo: Malheiros, 2010. p. 820-824.

60 SANTILLI, Juliana. Socioambientalismo e novos direitos. São Paulo: Peirópolis, 2005. p. 223.

61 SIMÕES, Maria do Socorro; GOLDER, Christophe. Santarém conta... Belém: Cejup, 1995. p. 41-42.

62 COSTA, Tony Leão da. Música, literatura e identidade amazônica no século XX: o caso do carimbó no Pará. Revista ArtCultura, Uberlândia, v. 12, n. 20, p. 61-81, jan.-jun. 2010.

63 Conforme reconhece o Movimento Tradicionalista Gaúcho, disponível em: $<$ http://www.mtg.org.br/chimarrao.html $>$. Acesso em: 24 jun. 2013. 
de autor. Seu processo criativo é distinto, pois apenas alguns de seus criadores são passíveis de identificação, não sendo possível localizar todos, uma vez que o processo de criação é transgeracional. Por isso, dada a complexidade do processo de desenvolvimento dessas manifestações culturais, estas não se enquadram de forma clássica no escopo de proteção do direito de autor. ${ }^{64}$ Desse modo, é importante verificar se ainda assim existe a possibilidade de aplicação do direito de autor a essas manifestações, bem como se há proteção dessas manifestações culturais de comunidades ou povos identificáveis, como é garantido constitucionalmente. Seria cabível sustentar que também na hipótese de manifestação cultural de expressão local, ou seja, com criadores identificáveis, os direitos atrelados a ela são difusos e a vertente intelectual dessa criação pertenceria à sociedade, como sustentou o acórdão de 1942 do Supremo Tribunal Federal, mencionado anteriormente?

É exatamente esse questionamento que este trabalho se propõe a responder. Por esse motivo, sugere-se a análise apenas das manifestações culturais imateriais de expressão local e produzidas por esses grupos identificáveis, definidos pela Constituição como grupos participantes do processo civilizatório nacional. Para finalizar a análise do artigo 216, observa-se que a Constituição também prevê nesse dispositivo que o Estado protegerá e promoverá as manifestações das culturas populares, indígenas e afro-brasileiras, e das de outros grupos participantes do processo civilizatório nacional, por meio, por exemplo, de inventários, registros, vigilância, tombamento e desapropriação. Ou seja, pela análise realizada, já é possível responder parcialmente à primeira questão: constando-se que existem direitos relacionados ao patrimônio cultural imaterial, resta compreender a extensão de cada um desses direitos. Para Uadi Lammêgo Bulos, ${ }^{65}$ promover é divulgar os bens de interesse da cultura nacional para que sejam do conhecimento de todos. Por sua vez, inventariar é relacionar as manifestações culturais brasileiras, registrar implica determinar quais os bens culturais, dentre todos os demais bens, devem ser objeto de tutela, seguindo-se os

64 RODRIGUES JUNIOR, Edson Beas. Tutela juridical dos recursos da biodiversidade, dos conhecimentos tradicionais e do folklore: uma abordagem de desenvolvimento social. Rio de Janeiro: Elsevier, 2010. p. 64-74.

65 BULOS, Uadi Lammêgo. Curso de direito constitucional. 6. ed. rev. e atual. São Paulo: Saraiva, 2011. p. 1570. 
parâmetros constitucionais para tanto, e proteger é importante para manter a manifestação cultural viva e conhecida.

Vigiar, de acordo com esse autor, é entendido como o ato de cuidar do patrimônio cultural, a fim de que ele não seja pichado ou sujeito a vandalismo, contudo a vigilância também se aplica ao patrimônio cultural imaterial para que não se permita que determinada manifestação cultural de um povo ou de uma comunidade seja ridicularizada ou apropriada indevidamente ou, ainda, utilizada sem o consentimento daqueles que a detêm. Por fim, para o autor, tombar seria o ato de proteção ao patrimônio público, para a tutela do patrimônio cultural e natural, mediante o qual o bem passaria a ser de interesse de todos e não mais de um único proprietário. Atualmente, o tombamento é regulamentado para ser usado apenas na tutela do patrimônio cultural material, não havendo regulamentação para a previsão de tombamento de manifestação cultural imaterial, o que não quer dizer que não haja outros mecanismos na legislação em vigor para tutelar o patrimônio cultural imaterial. ${ }^{66}$

Inclusive, muito embora a própria Constituição mencione que se faz necessária a existência de lei ordinária para a previsão de sanções aos danos e ameaças ao patrimônio cultural, ${ }^{67}$ pode-se sustentar que, mesmo enquanto pendente a regulamentação das sanções, caso haja descumprimento às diretrizes já em vigor na legislação nacional para uso do patrimônio cultural imaterial de determinada comunidade tradicional que resulte em danos, esta poderá ingressar com demanda judicial a fim que sejam apurados pelo Poder Judiciário a extensão dos danos sofridos e os direitos violados em razão do descumprimento aos princípios vigentes em nosso ordenamento, bem como a sanção ou indenização necessária para reparar o status quo ante, em função dos conceitos e fundamentos que serão apresentados adiante, ${ }^{68}$ especialmente em função desses direitos culturais garantidos constitucionalmente.

BULOS, Uadi Lammêgo. Curso de direito constitucional. 6. ed. rev. e atual. São Paulo: Saraiva, 2011. p. 1570.

67 Artigo 216, § 4. ${ }^{\circ}$, da Constituição Federal.

68 Como se verá adiante, o conteúdo do patrimônio cultural imaterial expressa direito da personalidade coletivo e, portanto, classificado como direito fundamental do indivíduo e do grupo ao qual pertence. 


\subsection{Direitos culturais}

Além de definir o conceito de patrimônio cultural brasileiro, a Constituição também prevê a existência de direitos culturais e de acesso às fontes de cultura, estabelecendo obrigação ao Estado de garantir o exercício a esses direitos, além de apoiar, incentivar e valorizar a difusão das manifestações culturais. ${ }^{69}$ A Constituição Federal, por meio de seu artigo 215, assegura a todos o pleno exercício dos direitos culturais, muito embora não defina o que sejam tais direitos. E ainda garante o acesso às fontes de cultura nacional, bem como a valorização e difusão das manifestações culturais, atribuições estas que cabem ao Estado executar. Em perfeita harmonia com a disposição do caput, o $\S 1 .^{\circ}$ desse mesmo artigo apresenta o dever de o Estado proteger as manifestações das culturas populares, indígenas e afro-brasileiras, e das de outros que tenham participado do processo civilizatório nacional, nos seguintes termos: " $§ 1 .^{\circ} \mathrm{O}$ Estado protegerá as manifestações das culturas populares, indígenas e afro-brasileiras, e das de outros grupos participantes do processo civilizatório nacional".

Para a melhor compreensão do texto constitucional, primeiramente esclarece-se o conceito de manifestações culturais, que devem ser entendidas como a externalização das práticas, fatos e atividades culturais, tais como exibições, rituais, concertos, mostras etc., e, em seguida, avalia-se o que são direitos culturais. Para Lucia Reisewitz, os direitos culturais seriam o reconhecimento de que para o desenvolvimento dos povos e, em consequência, da vida humana a identidade e a memória cultural são essenciais e, portanto, constituiriam o direito ao acesso à cultura. ${ }^{70}$ Por seu turno, de acordo com José Afonso da Silva, o conceito de direitos culturais é bidimensional, na medida em que compreende, por um lado, o direito cultural como norma agendi, ${ }^{71}$ isto é, aquela norma jurídica que fixa a obrigação para o Estado garantir o acesso à cultura nacional, por exemplo, e, ao mesmo tempo, cria a faculdade ao beneficiário de dispor desse direito, já que ele poderá buscar - ou não - o acesso à cultura, disponibilizado

$69 \quad$ Conforme o caput do artigo 215: "O Estado garantirá a todos o pleno exercício dos direitos culturais e acesso às fontes da cultura nacional, e apoiará e incentivará a valorização e a difusão das manifestações culturais".

70 REISEWITZ, Lúcia. Direito ambiental e patrimônio cultural: direito à preservação da memória, ação e identidade do povo brasileiro. São Paulo: Juarez de Oliveira, 2004. p. 65.

71 SILVA, José Afonso da. Comentário contextual à Constituição. 7. ed. São Paulo: Malheiros, 2010. p. 822 . 
pelo Estado, ou seja, o direito cultural como facultas agendi. ${ }^{72}$ Portanto, o direito à cultura envolveria a faculdade ou a possibilidade de agir e de usufruir desse direito, nos termos definidos pela norma jurídica, sendo consequência de tal faculdade a criação de obrigação ao Estado, que para adimplir deve estabelecer uma política cultural.

Como decorrência dessas disposições constitucionais e dos direitos culturais criados, vê-se que, para a consecução do papel do Estado, é essencial o estabelecimento de políticas públicas que determinem as normas que regularão as relações culturais em seu aspecto jurídico, de modo a criar um ordenamento jurídico próprio para regular os direitos culturais, qual seja o direito da cultura, ramo ainda em formação, conforme entendimento de José Afonso da Silva. ${ }^{73}$ Esses direitos da cultura, para Alain Riou, ${ }^{74}$ teriam quatro dimensões, quais sejam: o direito patrimonial da cultura, o direito da criação e da formação cultural, o mecenato cultural e a propriedade literária e artística, o que de certa forma se assemelharia ao conceito de direitos morais, trazido do direito de autor. Tais dimensões seriam aplicadas às atividades culturais públicas ou privadas, reconhecendo, portanto, que existem ao menos esses dois tipos de atividades culturais. Contudo, há, ainda, o entendimento, também provindo do Direito francês, de que o direito da cultura poderia se caracterizar pela prestação de um serviço público de cultura, atrelada à constituição de uma polícia da cultura e um contencioso especializado para esse fim. ${ }^{75}$

A primeira proposta analisada demonstra o entendimento de que os direitos culturais são complexos e múltiplos, possuindo ramificações que impõem obrigações ao Estado para a promoção e proteção da cultura, mas que também regulam direitos decorrentes da manifestação cultural, inclusive privados, na medida em que se indica a necessidade de haver uma tutela patrimonial associada à manifestação cultural e até mesmo disposição sobre sua vertente moral, como se depreende da terminologia "propriedade literária e artística". Todavia, de acordo com o segundo modelo

72 SILVA, José Afonso da. Comentário contextual à Constituição. 7. ed. São Paulo: Malheiros, 2010. p. 822 .

73 Idem, ibidem, p. 823.

$74 \quad$ RIOU, Alain. Le Droit de la Culture et le Droit à la Culture. 2. ed. Paris: ESF, 1996. p. 37.

75 PONTIER, Jean-Marie; BOURDON, Jacques; RICCI, Jean-Claude. Droit de la Culture. Paris: Dalloz, 1990. p. 90. 
apresentado, verifica-se o entendimento de que a regulação do patrimônio cultural envolveria apenas demandas ao Estado, que poderia, por meio de investimento em infraestrutura e atos cartoriais, promover a tutela e promoção dos direitos culturais.

Ainda que para a tutela dos direitos relacionados ao patrimônio cultural imaterial não exista regulamentação específica, no direito pátrio, que possa dar margem à criação de um direito da cultura no momento atual, pelo Texto Constitucional já é possível identificar que o legislador buscou atribuir pelo menos duas dimensões ao patrimônio cultural. Assim, estabelecem-se ao menos dois feixes de direitos ${ }^{76}$ que devem ser tutelados pelo Estado para que se alcancem os objetivos definidos pela Constituição Federal.

O primeiro deles destina-se a toda a sociedade e busca garantir o acesso à cultura, sua proteção, valorização e o exercício desses direitos. $\mathrm{O}$ segundo feixe de direitos objetiva tutelar a manifestação cultural dos grupos participantes do processo civilizatório nacional, ou seja, é um direito que, em caráter primário, objetiva assegurar os direitos de determinados grupos identificáveis e criadores de manifestações culturais, e não de toda a sociedade, ainda que, em caráter secundário, tal proteção objetive a promoção e a conservação das manifestações culturais do País como um todo e o benefício da sociedade.

A esse respeito, veja-se na relação de direitos culturais reconhecidos pela Constituição como tais direitos culturais ou se destinam à proteção dos titulares/criadores da manifestação cultural, como dispõem os itens 1 a 3, a seguir, ou à promoção de direitos que beneficiem a sociedade como um todo, nos termos dos itens 4 a 6. Assim, de acordo com José Afonso da Silva, os direitos culturais reconhecidos pela Constituição são: 1. a liberdade de expressão da atividade intelectual, artística, científica; 2. direito de criação cultural, compreendidas as criações artísticas, científicas e tecnológicas; 3. direito de proteção às manifestações das culturas populares, indígenas e afro-brasileiras e de outros grupos participantes do processo civilizatório nacional; 4. direito de acesso às fontes de cultura; 5. direito de difusão das manifestações culturais;

76 SAlOMÃO FILHO, Calixto. Regulação, desenvolvimento e meio ambiente. In: —— (Org.). Regulação e desenvolvimento. 2011. No prelo. 
6. direito estatal de formação do patrimônio cultural brasileiro e de proteção dos bens de cultura.

Quanto à utilização, no texto constitucional, da expressão "culturas populares, indígenas e afro-brasileiras e de outros grupos participantes do processo civilizatório nacional", para a efetiva compreensão da extensão do reconhecimento conferido às manifestações culturais desses grupos, necessário entender seu significado. O Texto Constitucional buscou ser o mais abrangente possível na definição e reconhecimento das manifestações culturais de grupos determináveis e optou por incluir não apenas os povos indígenas e afro-brasileiros, que certamente participam do processo civilizatório nacional, mas também os grupos caboclos, tradicionais, entre outros, que conservam, da mesma forma, manifestações culturais próprias. Quanto à expressão “processo civilizatório nacional”, importante observar ela não deve ser interpretada no sentido de que cultura se equivaleria a civilização, tampouco deve ser entendido que a Constituição estaria adotando o conceito antropológico de cultura, mas, sim, deve ser considerada como sinônimo de evolução sociocultural do Brasil. ${ }^{77}$

Adicionalmente, por meio da Emenda Constitucional n. ${ }^{\circ} 48$ de 2005, as formas de promoção e proteção do patrimônio cultural foram mais detalhadas no Texto Constitucional, tendo sido prevista a criação de um Plano Nacional de Cultura para o desenvolvimento cultural do País, com o objetivo de promover: (i) a defesa e a valorização do patrimônio cultural brasileiro; (ii) a produção, a promoção e a difusão de bens culturais; (iii) a formação de pessoal qualificado para a gestão da cultura em suas múltiplas dimensões; (iv) a democratização do acesso aos bens de cultura; (v) a valorização da diversidade étnica e regional. Demonstra-se, assim, que a Constituição Federal reconhece a relevância do patrimônio cultural nacional e dos direitos culturais a ele associados, buscando defini-lo de forma bastante ampla, ${ }^{78}$ incluindo todas as manifestações e expressões tradicionais de cunho cultural e que refletem os modos de criar, fazer e viver de determinadas populações, entre outras espécies de manifestações culturais, sejam materiais ou imateriais.

\footnotetext{
77 RIBEIRO, Darcy. O processo civilizatório. 2. ed. Rio de Janeiro: Civilização Brasileira, 1972. p. 27.

78 MARCHESAN, Ana Maria Moreira. A tutela do patrimônio cultural sob o enfoque do direito ambiental. Porto Alegre: Livraria do Advogado, 2007. p. 53.
} 
Nesse sentido, importante observar que as normas infraconstitucionais, tais como as disposições existentes na lei de direitos autorais (LDA) ${ }^{79}$ e nos tratados e convenções internacionais sobre o tema, ratificadas pelo Brasil, estão em linha com o disposto na Constituição Federal, e também devem ser analisadas para compreensão do conceito de patrimônio cultural imaterial, posto que são fonte de direito interno para a regulamentação desse tema, de acordo com o que se verá adiante. Contudo, antes de se realizar tal análise, para que seja possível a resposta à primeira pergunta, com a identificação dos direitos existentes para proteção das manifestações culturais detidas por povos e comunidades tradicionais, será avaliada a natureza jurídica do patrimônio cultural imaterial e dos direitos culturais a ele associados.

\subsubsection{Ressalva quanto à terminologia adotada}

Antes de prosseguir com a análise da natureza jurídica do patrimônio cultural imaterial, importante esclarecer os conceitos e as terminologias que serão adotadas no presente trabalho para tratar dos "grupos participantes do processo civilizatório nacional", bem como das expressões integrantes do patrimônio cultural imaterial.

\subsubsection{Manifestações culturais}

No tocante aos bens culturais imateriais que compõem o patrimônio cultural brasileiro, ou seja, as expressões artísticas, danças, músicas, literatura, rituais, festas, pinturas, línguas etc. serão denominadas como expressões culturais ou manifestações culturais, para fins de diferenciá-las do conceito de obras, próprias do direito de autor.

Assim, embora possam ser utilizadas outras nomenclaturas para tratar desses bens culturais imateriais, como expressões culturais tradicionais, ${ }^{80}$ expressões de

\footnotetext{
BRASIL. Lei n. ${ }^{\circ}$ 9.610, de 19 de fevereiro de 1998. Diário Oficial da União. Brasília, 20 fev. 1998.

80 UNESCO. Convenção para Proteção e Promoção das Expressões Culturais Tradicionais, 2005.
} 
folclore ${ }^{81}$ conhecimento tradicional, conhecimento tradicional associado, ${ }^{82}$ optou-se por utilizar a terminologia de conceitos mais abrangentes, que incluem todas as manifestações culturais abarcadas pelo amplo conceito trazido pela Constituição, isto é, as manifestações culturais artísticas, assim como as manifestações próprias do dia a dia tradicional, os conhecimentos tradicionais, os artefatos, artesanatos, expressões literárias, musicais, os conhecimentos relacionados à natureza, as línguas etc.

Ressalte-se que as expressões culturais tradicionais, sinônimo de expressões de folclore, referem-se às manifestações artísticas, nos termos que serão apresentados adiante, quando da análise da Convenção para Proteção e Promoção das Expressões Culturais Tradicionais. Já a expressão conhecimentos tradicionais concerne aos saberes técnicos ${ }^{83}$ detidos por determinada comunidade a respeito do "mundo natural, sobrenatural, gerados no âmbito da sociedade não urbano/industrial, transmitidos oralmente de geração em geração", 84 e que indicam a conexão existente, para essas comunidades, entre o meio ambiente natural, o social e cultural.

A OMPI, ${ }^{85}$ embora faça a ressalva de que não é possível apresentar conceito único de conhecimento tradicional, pois reconhece que cada comunidade poderá indicar o que compõe seus saberes tradicionais, define conhecimento tradicional como:

[...] trabalhos literários, artísticos e científicos baseados na tradição; performances; invenções; descobertas científicas; desenhos; marcas; nomes e símbolos; informação não divulgada; e todas as outras inovações e criações baseadas na tradição resultantes da atividade intelectual nas áreas industrial, científica, literária, ou artística. "Baseados na tradição" refere-se ao sistema de conhecimento,

81 UNESCO. Model provisions for National laws on the protection of expressions of folklore against illicit exploitation and other prejudicial actions, 1985. Disponível em: $<$ http://www.wipo.int/export/sites/www/tk/en/documents/pdf/1982-folklore-model-provisions.pdf>. Acesso em: 27 jun. 2012.

BRASIL. Medida Provisória n. ${ }^{\circ}$ 2.186-16/2001. Diário Oficial da União. Brasília, 24 ago. 2001. conhecimentos tradicionais e do folklore: uma abordagem de desenvolvimento social. Rio de Janeiro: Elsevier, 2010. p. 19. 2000. passim. Disponível em: <http://www.usp.br/nupaub/cienciabio.pdf>. Acesso em: 9 jul. 2012. 
criações, inovação e expressões culturais que: foram transmitidas de geração a geração; são consideradas como pertencentes a uma pessoa específica ou a seu território; e estão constantemente evoluindo em resposta às mudanças no meio ambiente. ${ }^{86}$

Ainda, ressalta que os conhecimentos tradicionais podem incluir saberes sobre agricultura, ciência, meio ambiente, biodiversidade, conhecimentos técnicos e medicinais, além das próprias expressões de folclore na forma de músicas, dança, canções, artesanato, literatura, pintura, elementos da língua, como nomes e indicações de lugares e símbolos. Assim, estariam excluídas do conceito de conhecimentos tradicionais as expressões que não resultem da produção intelectual nos campos industriais, científico, literário e artístico, ou seja, o patrimônio arqueológico, a língua em seu sentido geral e outros elementos do patrimônio cultural em sentido amplo.

Por fim, nos termos acima descritos, existe ainda o conceito de conhecimento tradicional associado ao patrimônio genético, definido e regulado no ordenamento jurídico nacional pela Convenção sobre Diversidade Biológica e Medida Provisória n. ${ }^{\circ}$ 2.186-16, de 23 de agosto de 2001. O objetivo do presente trabalho não é apresentar a regulamentação e o tratamento adotados especificamente para essa modalidade de conhecimento tradicional, mas apenas indicar que mesmo esse tipo específico de conhecimento tradicional se encontra inserido no conceito de patrimônio cultural imaterial, definido pela Constituição, dentro dos modos de fazer, viver e criar.

Dessa maneira, o conhecimento tradicional associado ao patrimônio genético $^{87}$ são os saberes tradicionais, de transmissão oral, ${ }^{88}$ sobre os usos, manejos, propriedades e funcionalidades do patrimônio genético brasileiro, ou seja, das espécies

86 Tradução livre. Texto original: "tradition-based literary, artistic or scientific works; performances; inventions; scientific discoveries; designs; marks, names and symbols; undisclosed information; and all other tradition-based innovations and creations resulting from intellectual activity in the industrial, scientific, literary or artistic fields. 'Tradition-based' refers to knowledge systems, creations, innovations and cultural expressions which: have generally been transmitted from generation to generation; are generally regarded as pertaining to a particular people or its territory; and, are constantly evolving in response to a changing environment".

Definido como: "informação ou prática individual ou coletiva de comunidade indígena ou de comunidade local, com valor real ou potencial, associada ao patrimônio genético". Cf. artigo $7 .^{\circ}$, inciso II, da Medida Provisória n. ${ }^{\circ}$ 2.126-16/2001. 
da fauna e flora que compõem a biodiversidade brasileira. ${ }^{89}$ São aqueles saberes sobre usos medicinais de plantas, sobre forma de colheita, plantio, como alimentar ou reabilitar animais etc., com valor real ou potencial. Veja-se que, embora integrantes do patrimônio cultural imaterial, os conhecimentos tradicionais associados recebem tratamento jurídico distinto, pois há norma específica para disciplinar sua forma de uso e exploração e, justamente por esse motivo, os conhecimentos tradicionais associados não serão objeto de análise da presente dissertação.

Para que fique mais claro o que configura patrimônio cultural imaterial em sentido lato e o que é o conhecimento tradicional associado a patrimônio genético, faz-se necessário, primeiramente, observar que, enquanto este é uma modalidade de conhecimento atrelado a patrimônio genético e que precisa ter valor real ou potencial, de acordo com o que dispõe sua definição legal, para ser caracterizado, o patrimônio cultural inclui qualquer modalidade de conhecimento ou práticas relacionadas à natureza, e não precisa ter uma finalidade de uso - como para pesquisa - ou qualquer valor real ou potencial. Verifica-se que o patrimônio cultural prescinde de qualquer finalidade ou uso para ser caracterizado, diferentemente dos conhecimentos tradicionais associados, que se constituem como uma "espécie" do "gênero" patrimônio cultural. ${ }^{90}$

Portanto, os conhecimentos tradicionais, sejam associados ou não ao patrimônio genético, estão contidos no conceito de patrimônio cultural, dado que traduzem os saberes, além dos modos de fazer, viver e criar decorrentes da relação entre homem e natureza. Nesse sentido, veja-se a própria conclusão da OMPI:

De acordo com o ponto de vista da OMPI, "expressões de folclore" são uma subdivisão e estão incluídas no escopo do "conhecimento

89 Os conhecimentos tradicionais associados ao patrimônio genético estão sujeitos ao regime instituído pela Medida Provisória n. ${ }^{\circ}$ 2.186-16/2001, de acordo com o qual, para o acesso a esses conhecimentos tradicionais, para fins de realização de pesquisas científicas, bioprospecção ou desenvolvimento tecnológico, deverá ser precedido da obtenção de consentimento prévio do provedor desse conhecimento, além da celebração de contrato para repartição de benefícios e obtenção de autorização junto ao Conselho de Gestão do Patrimônio Genético. Justamente por essa modalidade de conhecimento tradicional já possuir tratamento jurídico específico, não será objeto de análise do presente trabalho.

90 Conforme disposto no próprio texto da Medida Provisória n. ${ }^{\circ}$ 2.186-16/2001 em seu artigo 8..$^{\circ}$ § 2. ${ }^{\circ}$ : "O conhecimento tradicional associado ao patrimônio genético de que trata esta Medida Provisória integra o patrimônio cultural brasileiro e poderá ser objeto de cadastro, conforme dispuser o Conselho de Gestão ou legislação específica". 
tradicional". "Conhecimento tradicional", por sua vez, uma subdivisão do conceito mais amplo de "patrimônio" $" 1-92$ - aqui entendido com patrimônio cultural imaterial.

Por fim, para definição das manifestações culturais de comunidades ou povos tradicionais, utilizaremos a conceituação de Carlos Alberto Bittar ${ }^{93}$ e de Walter Moraes. ${ }^{94}$ Para o primeiro, é a partir da criação que surgem os direitos sobre as obras intelectuais. Para o segundo, só deve ser protegida a obra que atenda aos requisitos de criatividade, originalidade, exterioridade e que não seja resultado de mero trabalho mecânico. Ora, as criações coletivas que levam ao desenvolvimento das manifestações culturais atendem a tais requisitos, dado que são manifestações criativas, apresentam, em regra, originalidade, ainda que outras comunidades ou povos possam também desenvolver manifestações culturais semelhantes e que com o passar do tempo e repetição da manifestação esta tenda a perder originalidade; quanto ao requisito de exterioridade, tais manifestações podem ser exteriorizadas, ainda que em muitos casos não sejam e permaneçam sendo transmitidas pela cultura oral, por fim, são criações que não resultam apenas de trabalho mecânico, sendo, em realidade, decorrência de trabalhos intelectuais coletivos. Dessa forma, identificados os requisitos supra na produção das criações coletivas de comunidades ou povos tradicionais identificáveis e vivas, estaremos diante das manifestações culturais avaliadas no presente estudo.

\subsubsection{Comunidades tradicionais}

A Constituição, ao reconhecer as manifestações da cultura popular, indígena, afro-brasileira e dos outros grupos que contribuem para o processo

91 Tradução livre. Texto original: “From WIPO’s perspective, 'expressions of folklore' are a subset of and included within the notion 'traditional knowledge'. 'Traditional knowledge' is, in turn, a subset of the broader concept of "heritage"'.

92 WIPO. Intellectual Property Needs and Expectations of Traditional Knowledge Holders: WIPO Report on Fact-finding Missions on Intellectual Property and Traditional Knowledge (1998-1999). WIPO, 2001. p. 26.

93 BITTAR, Carlos Alberto. Direito de autor. 4. ed. atual. por Eduardo C.B. Bittar. São Paulo: Forense Universitária, 2003. p. 32.

94 MORAES, Walter. Direito de autor. In: LIMONGI FRANÇA, Rubens (Org.). Enciclopédia Saraiva do Direito. São Paulo: Saraiva, 1977. v. 9, p. 269-302. 
civilizatório nacional, adotou a expressão genérica "grupos" para tratar dos diferentes povos e comunidades que desenvolvem e conservam o patrimônio cultural brasileiro. Contudo, dada a complexidade da utilização de uma expressão antropológica para representar a diversidade desses "grupos", que, como indicado na Constituição, podem ser indígenas, quilombolas e, ainda, tradicionais, locais, ribeirinhos, caboclos, caiçaras, pantaneiros etc., ${ }^{95}$ certamente o uso de uma expressão única para a reunião desse conjunto implicará não adequar alguns desses termos à terminologia escolhida. ${ }^{96}$

Mesmo do ponto de vista antropológico, a definição desse grupo único não é tarefa simples. Rinaldo Arruda se vale da expressão "sociedades tradicionais", 97 afirmando que a utiliza por falta de outra mais adequada, considerando-a razoável tanto para especificar os povos indígenas quanto a população que desenvolveu alguma forma particular de organização e relação com a natureza. E define as sociedades tradicionais como os "grupos humanos culturalmente diferenciados que historicamente reproduzem seu modo de vida, de forma mais ou menos isolada, com base em modos de cooperação social e formas específicas de relações com a natureza $\left[\ldots .\right.$. ". ${ }^{98}$

Após a análise das definições no campo da antropologia, necessário considerar tal conceito na esfera do direito. Assim, indicaremos a terminologia adotada para este trabalho, apresentando as ressalvas cabíveis, visando minimizar os possíveis desajustes que a escolha do termo poderá causar. Portanto, adotaremos a terminologia da Política Nacional de Desenvolvimento Sustentável dos Povos e Comunidades Tradicionais, ${ }^{99}$ que se vale da expressão "povos e comunidades tradicionais", ${ }^{100}$ aqui

95 DIEGUES, Antônio Carlos Sant'Ana. Biodiversidade e comunidades tradicionais. Cidade: NUPAUB, 1999. p. 3.

96 MOREIRA, Eliane. Conhecimento tradicional e a proteção. T\&C Amazônia, ano V, n. 11, p. 34, jun. 2007.

97 De acordo com Rinaldo Arruda, exemplos empíricos de populações tradicionais são as comunidades caiçaras, os sitiantes e roceiros tradicionais, comunidades quilombolas, comunidades ribeirinhas, os pescadores artesanais, os grupos extrativistas e indígenas. Exemplos empíricos de populações não tradicionais são os fazendeiros, veranistas, comerciantes, servidores públicos, empresários, empregados, donos de empresas de beneficiamento de palmito ou outros recursos, madeireiros etc. (Populações tradicionais e a proteção dos recursos naturais em unidades de conservação. Anais do Primeiro Congresso Brasileiro de Unidades de Conservação, v. 1. Conferências e Palestras, 1997, p. 5. conservação. Anais do Primeiro Congresso Brasileiro de Unidades de Conservação, v. 1. Conferências e Palestras, 1997. p. 5. 
utilizada no sentido disposto no próprio Decreto, e para abarcar tanto as comunidades locais ${ }^{101}$ como os povos indígenas, reconhecendo, nesse aspecto, que, nos termos da Convenção 169 da Organização Internacional do Trabalho, os povos indígenas devem ser identificados como povos e não comunidades, sendo a terminologia aqui adotada apenas para facilitar a análise e o tratamento do tema patrimônio cultural imaterial, detido pelas comunidades ou povos tradicionais, sem contudo deixar de considerar o preceito específico disposto pela Convenção 169 da OIT.

Importante destacar que a terminologia utilizada também pretende alcançar o conceito de povos autóctones, ${ }^{102}$ adotado por algumas legislações, além do conceito de comunidades locais e povos indígenas, empregado pela Convenção sobre Diversidade Biológica, ${ }^{103}$ de populações tradicionais ${ }^{104}$ e sociedades tradicionais, supradefinidas.

\subsection{Natureza jurídica do patrimônio cultural imaterial}

Para melhor compreensão do instituto do patrimônio cultural imaterial e os direitos a ele relacionados, importante observar sua natureza jurídica, inclusive avaliando se os distintos feixes de direitos que emanam da definição constitucional de patrimônio cultural, antes definidos, poderiam ter naturezas jurídicas distintas. No entendimento de Celso Antonio Pacheco Fiorillo, ${ }^{105}$ o patrimônio cultural compõe o rol

100 Definindo povos e comunidades tradicionais como "grupos culturalmente diferenciados e que se reconhecem como tais, que possuem formas próprias de organização social, que ocupam e usam territórios e recursos naturais como condição para sua reprodução cultural, social, religiosa, ancestral e econômica, utilizando conhecimentos, inovações e práticas gerados e transmitidos pela tradição", nos termos do art. $3 .^{\circ}$, inciso I, do Decreto n. ${ }^{\circ} 6.040 / 2007$.

101

As comunidades locais são definidas como: "grupo humano, incluindo remanescentes de comunidades de quilombos, distinto por suas condições culturais, que se organiza, tradicionalmente, por gerações sucessivas e costumes próprios, e que conserva suas instituições sociais e econômicas", nos termos do artigo 7..$^{\circ}$, inciso III, da Medida Provisória n. ${ }^{\circ}$ 2.186-16/2001.

Autóctone significa: "que é originário do lugar em que se encontra". ACADEMIA BRASILEIRA DE LETRAS. Dicionário escolar da língua portuguesa. 2. ed. São Paulo: Nacional, 2008. p. 180.

Cf. dispõe seu artigo 8 (j): “comunidades locais e populações indígenas com estilos de vida tradicionais".

Expressão adotada por Eliane Moreira, para expressar povos indígenas, quilombolas e as comunidades locais (Conhecimento tradicional e a proteção. T\&C Amazônia, ano V, n. 11, p. 34, jun. 2007).

105 FIORILlo, Celso Antônio Pacheco. Curso de direito ambiental brasileiro. 13. ed. São Paulo: Saraiva, 2012. p. 423-435. 
de bens ambientais e, como tal, possuiria natureza jurídica de bem difuso. Para José Afonso da Silva, o patrimônio cultural implica a garantia de direito à cultura e, portanto, impõe ao Estado obrigações de garantir tal direito, possuindo, assim, em seu entendimento, natureza de direito constitucional fundamental. Ainda, sustenta José Afonso da Silva ${ }^{106}$ que os bens culturais pertenceriam à nova categoria de bens, quais sejam os bens de interesse público, que poderiam ser bens pertencentes a sujeitos públicos ou privados, mas que deveriam ter regulação jurídica especial para fins de que um interesse público fosse alcançado.

O tratamento jurídico especial relativo a esses bens implicaria regime diferenciado para seu uso e disponibilidade, além de regime particular de polícia e tutela pública, o que significa que, para essa categoria de bens, haveria o controle de sua circulação jurídica e o de seu uso, pois a circulação e o uso de bens privados normalmente excluem os demais. Portanto, tanto o meio ambiente cultural quanto o natural possuiriam natureza de bem de interesse público. A respeito de interesse público, importante notar a distinção conceitual proposta por Renato Alessi, ${ }^{107}$ que identifica a existência de um interesse público primário e outro secundário. $\mathrm{O}$ primário seria o legítimo interesse da coletividade, que a administração deve buscar, como sua função primeira, e os interesses públicos secundários seriam os interesses particulares e específicos da administração, como sujeito de direitos, que não se relacionam aos interesses coletivos. Assim, os interesses públicos secundários somente deveriam ser realizados se compatíveis e no exato limite do interesse primário que a administração deve materializar em sua atuação, em prol de toda a coletividade.

Ainda, exemplifica Renato Alessi ${ }^{108}$ que os interesses públicos secundários poderiam levar a administração a remunerar seus funcionários com o menor salário possível e a incrementar os tributos ao maior denominador possível, a fim aumentar suas reservas. Veja-se que aumentar as reservas da Administração até pode ser, de fato, um ato de interesse público, mas desde que respeite o interesse público

\footnotetext{
106 SILVA, José Afonso da. Comentário contextual à Constituição. 7. ed. São Paulo: Malheiros, 2010. p. 83.

107 ALESSI, Renato. Sistema istituzionale del diritto ammnistrativo italiano. Milano: Giufrè, 1953. p. 151.

108 Idem, ibidem, p. 153.
} 
primário, não remunere de forma inadequada e injusta seus funcionários e aplique carga tributária razoável, que não inviabilize os interesses públicos primários. ${ }^{109}$ Por esse motivo, Renato Alessi sustentava que os interesses públicos primários deveriam ser defendidos pela coletividade, e não pela Administração, que já é responsável por sua gestão.

\section{A partir da conceituação de José Afonso da Silva e da classificação} proposta por Renato Alessi, verifica-se que o patrimônio cultural imaterial de fato pode ter natureza de interesse público e, nesse caso, seria classificado como interesse público primário. Contudo, em função do entendimento acima exposto, de que a norma constitucional garantiria dois feixes de direitos a partir do patrimônio cultural, verificase que a classificação do patrimônio cultural como interesse público trata apenas da dimensão do primeiro feixe de direitos identificado, destinado à sociedade, sendo necessário compreender quais outros direitos encerra para garantir os direitos dos povos ou comunidades tradicionais participantes do processo civilizatório nacional, como previsto pela Constituição.

109 Veja-se, a esse respeito, a incorporação desses conceitos, inclusive na jurisprudência: Direito constitucional e processual civil. Restituição de verbas recebidas a maior por servidores públicos. Dano ao patrimônio público. Ajuizamento de ação civil pública. Ilegitimidade do Ministério Público. Interesse individual e homogêneo da União, a qual é titular do direito. Recurso extraordinário a que se nega provimento. 1. As normas decorrentes da interpretação sistemática das previsões contidas na Constituição Federal e em diplomas legais conduzem ao entendimento de que dentre as funções típicas do Ministério Público, além da defesa da ordem jurídica, do regime democrático e dos interesses sociais e individuais indisponíveis, enquadra-se o ajuizamento de ação civil pública em defesa do patrimônio público e social, possibilidade destacada no rol de funções concorrentes da instituição. 2. O recebimento de verbas a maior, por servidores públicos federais, não legitima o Ministério Público para o ajuizamento de ação civil visando à devolução ao erário, no intuito de proteger o patrimônio público. 3. In casu, o acórdão recorrido assentou que (fl. 138): "Direito processual civil. ação civil pública. Gratificação natalina. Restituição de valores indevidamente pagos. Ilegitimidade ativa do Ministério Público Federal. Inexistência de interesse público primário. 1. A legitimação do Ministério Público para ajuizar demandas de natureza cível está adstrita ao princípio da tipicidade, nos termos do art. 81 do Código de Processo Civil, bem como na previsão contida no art. $6 .^{\circ}$, inciso VII, da Lei Complementar n. ${ }^{\circ}$ 75/1993. 2. No caso em tela, o objeto da lide está relacionado com o pagamento de vantagens e vencimentos dos servidores públicos federais, não se tratando de interesse difuso, e tampouco interesse coletivo. Trata-se de interesse individual da Fazenda Pública de eventualmente reaver valores pagos a maior aos seus próprios servidores. 3. Não houve sequer alguma narração fática relacionada à possível improbidade administrativa dos servidores ou daquele que teria decidido administrativamente pagar as quantias aos mesmos, inexistindo, portanto, interesse público primário a ser tutelado por meio de ação civil pública. 4. Apelação conhecida e improvida, com a manutenção da sentença”. 4. Impossibilidade do Ministério Público de substituir a titular do direito, no caso concreto, a União, uma vez tratar-se de direito individual homogêneo. 5. Recurso extraordinário a que se nega provimento. Decisão: Trata-se de recurso extraordinário interposto contra acórdão prolatado pela Quinta Turma do Tribunal Regional Federal da 2. ${ }^{\mathrm{a}}$ Região (fl. 138). 
Assim, o primeiro feixe de direitos seria o de interesse público, que trata dos direitos da sociedade de acesso à cultura e de valorização e registro dos bens que integram o patrimônio cultural. O segundo, por sua vez, não tratado na análise de José Afonso, seria o feixe de direitos coletivos, ou seja, dos grupos que criam manifestações culturais e que possuem direitos associados a elas, como sustentam Antônio Chaves, José Carlos Costa Netto e Victor Drummond, que devem ser reconhecidos, protegidos e respeitados, para que tais manifestações possam integrar o patrimônio cultural brasileiro em atendimento ao interesse público, mas sem violar os direitos coletivos desses grupos que contribuem para o processo civilizatório nacional.

Definida essa nomenclatura, importante compreender os direitos fundamentais para fins de identificação da natureza jurídica do patrimônio cultural e, especificamente, a natureza jurídica do feixe de direitos de interesse público e do feixe de direitos coletivos. De acordo com Konrad Hesse, ${ }^{110}$ os direitos fundamentais objetivam criar e manter os direitos essenciais para uma vida com liberdade e dignidade. Diante dessa definição e da constante utilização de expressões diversas para nominar direitos semelhantes a esse, Paulo Bonavides alerta para o fato de a teoria dos direitos fundamentais levantar primeiramente a dúvida sobre se as expressões "direitos humanos", "direitos do homem" e "direitos fundamentais" podem ser usadas indiferentemente. ${ }^{111}$

Explica, ainda, que os autores anglo-americanos empregam as expressões "direitos humanos" e "direitos do homem", enquanto os autores alemães preferem a terminologia "direitos fundamentais", adotada também pela Constituição brasileira. Para J.J. Gomes Canotilho, contudo, a expressão "direitos do homem" representa direitos de todos os povos, a qualquer tempo, em função de sua condição de homem, e por isso mesmo trata de direitos invioláveis, atemporais e universais, enquanto a expressão "direitos fundamentais" traduziria os direitos do homem garantidos e limitados jurídica e institucionalmente, de acordo com o local e o momento

\footnotetext{
110 HESSE, Konrad. Rundrechte. In: SAATSLEXIKON (Org.). Da Goerresgeselschaft, v. 2, p. 7 apud BONAVIDES, Paulo. Curso de direito constitucional. 26. ed. São Paulo: Malheiros, 2011. p. 560.

111 BONAVIDES, Paulo. Ibidem, p. 560-561.
} 
em que esse homem se localiza. Ou seja, os direitos vigentes, naquele momento, em determinada ordem jurídica. ${ }^{112}$

No mesmo sentido, Konrad Hesse sustenta que os direitos fundamentais são aqueles assim qualificados pelo direito então vigente. ${ }^{113}$ Ainda, para Dirley da Cunha Junior, ${ }^{114}$ os direitos fundamentais designariam os direitos humanos positivados e a expressão "direitos fundamentais" seria utilizada para designar tais direitos no campo do direito interno, enquanto se adotaria a expressão "direitos humanos" para tratar do tema no âmbito internacional. Ainda, para Luiz A. D. Araújo e Vidal S. Nunes Junior, os direitos fundamentais são categoria de direito prevista constitucionalmente para fins de tutelar "a dignidade humana em todas as dimensões", ou seja, para resguardar a liberdade do ser humano - por meio dos direitos a garantias individuais -, bem como suas necessidades -i.e., direitos econômicos, sociais e culturais - e sua própria preservação - por meio dos direitos à fraternidade e à solidariedade. ${ }^{115}$

Por esse motivo, os direitos fundamentais implicam também uma consequência institucional, na medida em que indicam a maneira como o Estado deve atuar para garantir tais direitos. Essa seria a medida necessária para a efetividade de um Estado Democrático de Direito, que não pode assim ser denominado se seus direitos fundamentais não são garantidos. Assim, os direitos fundamentais caracterizam-se por serem direitos positivados, que receberam da Constituição uma tutela especial, conferindo-lhes maior proteção e segurança, ${ }^{116}$ a fim de garantir, primordialmente, a dignidade da pessoa humana. Por esse motivo, são direitos absolutos, de acordo com Carl Schmitt, e, como tais, quaisquer relativizações ou limitações a esses direitos

CANOTILHO, Gomes J.J. Direito constitucional. 5. ed. Coimbra: Coimbra Ed., 1991. p. 529.

113 HESSE, Konrad. Rundrechte. In: SAATSLEXIKON (Org.). Da Goerresgeselschaft, v. 2, p. 7, passim.

114 CUNHA JUNIOR, Dirley da. Controle judicial das omissões do poder público. 2. ed. São Paulo: Saraiva, 2008. p. 157.

115 ARAÚJO, Luiz A. D.; NUNES JUNIOR, Vidal S. Curso de direito constitucional. 3. ed. São Paulo: Saraiva, 2003. p. 71-72.

116 BONAVIDES, Paulo. Curso de direito constitucional. 26. ed. São Paulo: Malheiros, 2011. p. 561. 
fundamentais devem ser interpretadas como exceções e realizadas por meio de lei de emenda à Constituição. ${ }^{117}$

Veja-se, portanto, a relevância de se reconhecerem os direitos culturais, atrelados ao patrimônio cultural como direitos fundamentais. Inclusive, a esse respeito, Dirley da Cunha Junior sustenta que tal reconhecimento como direito fundamental implica "superlativo reforço jurídico da eficácia dessas normas", e, como consequência, todas as normas que definem direitos fundamentais teriam eficácia imediata, independentemente de qualquer regulamentação, uma vez que, dada a sua relevância para o ordenamento jurídico, já deve beneficiar o titular do direito a partir do momento em que o integra.

Ainda, os direitos fundamentais podem ser materiais e formais, o que significa que determinados direitos são considerados fundamentais em função da matéria, de seu conteúdo, ainda que não estejam formalmente previstos na Constituição e sejam decorrentes de regimes ou princípios que ela institui ou estejam previstos em tratados internacionais, são os direitos implícitos. Justamente por existir a possibilidade de se sustentar que direitos não constantes da Constituição são fundamentais, Robert Alexy, ${ }^{118}$ em obra que é referência para o estudo de direitos fundamentais, estipula quais seriam os cinco requisitos que determinado direito deveria atender para ser considerado como fundamental, implícito.

Primeiramente, para que determinado direito se caracterize como fundamental, Robert Alexy sustenta que ele deve ser um direito universal, i.e., que se relacione a todo ser humano, podendo ser um direito detido, inclusive, por coletividades, sempre que forem necessários para a "realização de direitos do homem". O segundo requisito é que se trate de um direito moral, no sentido de que "valha moralmente". O terceiro requisito é que tal direito justifique sua tutela e positivação pelo Estado, sendo um direito preferencial, de acordo com a terminologia adotada por

117 SCHIMITT, Carl. Verfassungslehre. Berlim: Neukoeln, 1954. p. 163-175 apud BONAVIDES, Paulo. Curso de direito constitucional. 26. ed. São Paulo: Malheiros, 2011. p. 561.

11 ALEXY, Robert. Colisão de direitos fundamentais e realização de direitos fundamentais no estado de direito democrático. Revista de Direito Administrativo, Rio de Janeiro: Renovar, v. 217, p. 58, jul.-set. 1998 . 
Robert Alexy. ${ }^{119}$ O quarto requisito é que o direito realmente tenha relevante importância, e, para tanto, precisará tratar de interesses que devem ser protegidos pelo direito, além de serem tão fundamentais que sua proteção se justifique por se vincularem à dignidade da pessoa humana. Por fim, o quinto requisito é que tal direito seja abstrato e possa, assim, estar sujeito a restrições, mas deve pesar de forma decisiva para a vida. ${ }^{120}$

No tocante à relevância do direito à proteção das manifestações culturais para o direito à vida, importa analisar que a Corte Interamericana de Direitos Humanos já reconheceu em determinados casos que discutem o direito ancestral de povos indígenas à terra que a garantia da vinculação do povo à terra e a possibilidade do exercício de seus conhecimentos tradicionais é necessária para o direito à saúde e à vida. ${ }^{121}$ No caso do Povo Sawhoyamaxa que denunciou o Paraguai por violar direito à vida à propriedade privada e às garantias judiciais, ${ }^{122}$ o Estado não teria adotado os trâmites necessários para assegurar o direito à propriedade desse povo sobre sua terra, de modo que, tendo sido expulso de sua terra, o Povo Sawhayamaxa acabou por viver às margens de rodovias, sujeitos às condições degradantes do ponto de vista alimentar e de saúde, sem que pudessem sequer utilizar seus conhecimentos tradicionais sobre ervas medicinais, por exemplo, para tratar de seu povo, já que estes recursos naturais estavam no interior dos territórios que não podiam ser por eles acessados. Diante desse cenário, a Corte Interamericana reconheceu que a falta de garantia ao direito à terra ancestral levou à ameaça do direito à vida e à saúde desse povo, por não lhe ser garantido que

119 Tal requisito encontra fundamento na Declaração Universal de 1948, que prevê em seu artigo 28: "Toda pessoa tem direito a que reúne, no plano social e no plano internacional, uma ordem tal que os direitos e liberdades enunciados na presente Declaração aí possam ter pleno efeito”.

120 FERREIRA FILHO, Manoel Gonçalves. Direitos humanos fundamentais. 13. ed. São Paulo: Saraiva, 2011. p. 87-88.

121 MOREIRA, Elaine. Conhecimentos tradicionais como direitos humanos culturais. Revista Internacional de Direito e Cidadania, Instituto Estudos Direito e Cidadania. Edição especial biodiversidade. Erechim: Habilis, 2010. Disponível em: <http://www.reidespecial.org.br/? CONT $=00000252>$. Acesso em: 20 fev. 2014.

122 Segundo o Informe n. ${ }^{\text {1 }}$ 12/2003 de admissibilidade da denúncia realizada por meio da Petição 0322/2001, da comunidade indígena Sawhoyamaxa do povo Enxet., de 20 de fevereiro de 2003. Disponível em: <http://www.cidh.oas.org/Indigenas/Paraguay.12.419.htm>. Acesso em: 20 fev. 2014. 
pudessem viver conforme suas formas tradicionais e segundo sua cultura, nos termos do voto do Juiz Cançado Trindade: ${ }^{123}$

O direito à vida é, no presente caso da Comunidade Sawhoyamaxa, abordado em sua vinculação estreita e inevitável com a identidade cultural. Essa identidade se forma com o passar do tempo, com a trajetória histórica da vida em comunidade. A identidade cultural é um componente ou agregado do direito fundamental à vida em sua dimensão ampla. No que concerne aos membros de comunidades indígenas, a identidade cultural encontra-se estreitamente vinculada a suas terras ancestrais. Se os privam destas últimas, mediante sua retirada forçada, afeta-se seriamente sua identidade cultural e, em última instância, seu próprio direito à vida lato sensu, ou seja, o direito à vida de cada um e de todos os membros de cada comunidade. ${ }^{124}$

A partir desse voto, a Corte Interamericana decidiu que o Paraguai violou os direitos às garantias judiciais, à proteção judicial, ao direito de propriedade, à vida e ao direito à personalidade jurídica, condenando-o a entregar as terras ancestrais ao povo, arcando com indenização por danos morais e a constituição de um fundo comunitário de desenvolvimento, devendo o Estado disponibilizar os bens e serviços necessários para a sadia qualidade de vida desse povo até que a área de sua titularidade lhe seja outorgada. ${ }^{125}$ Com a análise desse caso, evidencia-se o reconhecimento de que o direito à proteção das manifestações culturais detidas por povos e comunidades tradicionais é direito fundamental, necessário inclusive para a garantia à vida.

123 CANÇADO TRINDADE. Voto razonado del Juez. Caso de la Comunidad Indígena Sawhoyamaxa versus Paraguay. Disponível em: <http://www.cidh.oas.org/Ninez/Sawhoyamaxa (80)/VOTO Cançado.doc-09/17/2009>. Acesso em: 20 fev. 2014.

124 Tradução livre. Texto original: "El derecho a la vida es, en el presente caso de la Comunidad Sawhoyamaxa, abordado en su vinculación estrecha e ineludible con la identidad cultural. Dicha identidad se forma con el pasar del tiempo, con la trayectoria histórica de la vida en comunidad. La identidad cultural es un componente o agregado del derecho fundamental a la vida en su amplia dimensión. En lo que concierne a los miembros de comunidades indígenas, la identidad cultural se encuentra estrechamente vinculada a sus tierras ancestrales. Si se les privan de estas últimas, mediante su desplazamiento forzado, se afecta seriamente su identidad cultural y, en última instancia, su propio derecho a la vida lato sensu, o sea, el derecho a la vida de cada uno y de todos los miembros de cada comunidad”. Disponível em: <http://www.reidespecial.org.br/ ?CONT $=00000252>$. Acesso em: 20 fev. 2014.

Conhecimentos tradicionais como direitos humanos culturais. Revista Internacional de Direito $e$ Cidadania, Instituto Estudos Direito e Cidadania. Edição especial biodiversidade. Erechim: Habilis, 2010. Disponível em: <http://www.reidespecial.org.br/?CONT=00000252>. Acesso em: 20 fev. 2014. 
A partir da classificação mencionada, é possível constatar que, ainda que os direitos de proteção ao patrimônio cultural imaterial das comunidades e povos tradicionais não estivessem formalmente previstos na Constituição Federal, eles seriam considerados direito fundamental sob a classificação proposta por Robert Alexy, antes exposta, uma vez que se enquadra em cada um dos requisitos propostos para classificar um direito como fundamental. De toda forma, ao se verificar que a Constituição Federal reconhece a dignidade da pessoa humana como fundamento da República e ainda prevê como direitos fundamentais o direito à vida, à liberdade, à igualdade, à segurança e à propriedade, que, para Luis Paulo Sirvinskas, ${ }^{126}$ estão relacionados na Constituição em ordem de importância, dado que existe hierarquia entre tais direitos, sendo o direito à vida o mais relevante em face dos demais, verifica-se que a tutela ao patrimônio cultural imaterial dessas comunidades e povos tradicionais é essencial para a garantia da vida, da liberdade e da dignidade da pessoa humana, individualmente e no grupo a que pertence, posto que é a cultura própria desse povo que o define e permite a execução dos modos tradicionais que lhe garantem a vida. Sem a proteção a tais manifestações culturais dessas comunidades, violam-se os direitos fundamentais constitucionalmente garantidos e, por consequência, a dignidade da pessoa humana e o direito à vida, como reconhecido pela Corte Interamericana de Direitos Humanos no caso acima citado.

Os direitos fundamentais podem ser analisados por diferentes enfoques e, como consequência, classificados de distintas formas. De acordo com Luiz A. D. Araújo e Vidal S. Nunes Junior, existem três classificações possíveis para os direitos fundamentais. Se analisados quanto aos valores que protegem, são classificados como conteudísticos e podem ser direitos fundamentais que protegem a liberdade ou o indivíduo perante as necessidades materiais - e nestes se enquadrariam os direitos relacionados à cultura - ou os direitos de preservação do ser humano. Se analisados quanto à evolução na tutela aos direitos fundamentais, seriam classificados a partir da evolução que a proteção à dignidade da pessoa humana sofreu ao longo do tempo. ${ }^{127}$

\footnotetext{
126 SIRVINSKAS, Luis Paulo. Tutela constitucional do meio ambiente: interpretação e aplicação das normas constitucionais ambientais no âmbito dos direitos e garantias fundamentais. 2. ed. São Paulo: Saraiva, 2010. p. 164-165.

127 ARAÚJO, Luiz A. D.; NUNES JUNIOR, Vidal S. Curso de direito constitucional. 3. ed. São Paulo: Saraiva, 2003. p. 112-116.
} 
Assim, a primeira etapa da evolução à proteção da dignidade da pessoa humana centrou seus esforços em desenvolver normas que garantissem o Estado de Direito e, portanto, as liberdades individuais por meio de direitos civis e políticos. Esses são os direitos de primeira geração que objetivam assegurar os direitos do indivíduo perante o Estado, caracterizando-se por serem direitos de resistência e oposição a este, promovendo distinção entre Sociedade e Estado, ${ }^{128}$ que até então era autoritário e não submisso a uma Constituição. São direitos civis e políticos, sendo previstos inicialmente no século XIX, em momento histórico em que se desejava que as funções do Estado fossem apenas no sentido de garantir as liberdades individuais e de se abster de qualquer intervenção nas relações sociais, por isso eram chamados de status negativus, isto é, direitos negativos. ${ }^{129}$ Ademais, de acordo com Paulo Bonavides, os direitos de primeira geração caracterizam-se por terem o indivíduo como seu titular e por serem oponíveis ao Estado, sendo que tais direitos atualmente já contam com reconhecimento e são previstos nas principais Constituições. ${ }^{130}$

No século XX, a evolução da proteção à dignidade da pessoa humana levou à constituição dos direitos de segunda geração, quais sejam os direitos sociais, culturais e econômicos, além dos direitos coletivos, idealizados à luz do princípio da igualdade. Tais direitos caminhavam em sentido oposto aos direitos de primeira geração, na medida em que buscavam exatamente a participação do Estado para garantir determinados direitos sociais e a igualdade perante a coletividade. Assim, por serem direitos que demandavam a participação do Estado, visando minimizar os problemas sociais, eram chamados de direitos positivos. ${ }^{131}$

Esses direitos caracterizavam-se por ter aplicabilidade mediata, dependendo da regulamentação pelo legislador, o que não prevalece na Constituição nacional, já que prevê a imediata aplicabilidade dos direitos fundamentais. ${ }^{132}$ Integram os direitos de segunda geração os direitos sociais, os econômicos e os culturais, nas

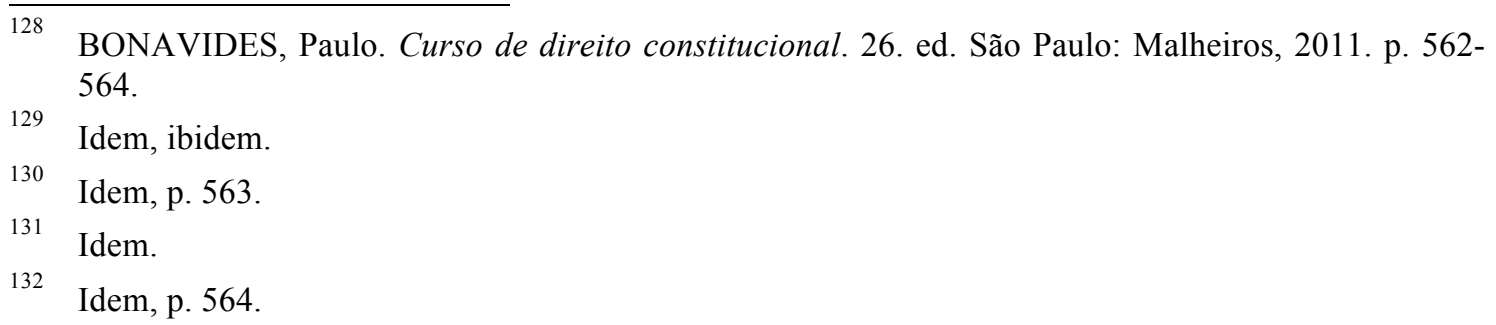


dimensões individuais e coletivas. Para Manoel Gonçalves Ferreira Filho, esses direitos são subjetivos, porém não conferem meros poderes de agir, mas sim direito a exigir do Estado, ${ }^{133}$ já que o Estado moderno, na acepção de Boris Mirkine-Guétzévitch, deveria garantir as condições necessárias, do ponto de vista jurídico, para a efetiva independência social do indivíduo, ${ }^{134}$ o que se traduziria por meio de serviços públicos, sendo o Estado o sujeito passivo desses direitos sociais.

$\mathrm{Na}$ Constituição nacional, os direitos de segunda geração estão previstos de forma inequívoca nos dispositivos que fixam dever ao Estado para fins de propiciar a saúde, a educação, a cultura e o lazer, por exemplo. ${ }^{135}$ A evolução na tutela da dignidade da pessoa humana, iniciada com a previsão dos direitos de primeira geração e continuada com os direitos de segunda geração, pode ser constatada na Declaração Universal dos Direitos do Homem, de 1948, promulgada pela Organização das Nações Unidas, que prevê tanto os direitos de liberdade quanto os sociais, congregando direitos de primeira e segunda geração em um único texto normativo, que busca o direito à vida em um parâmetro adequado. ${ }^{136}$

Quanto aos direitos fundamentais de terceira geração, estes são bastante recentes, tendo sido reconhecidos, primeiramente, por Karel Vasak em 1979, ${ }^{137}$ que os denominou de direitos da solidariedade, fundamentando-se na fraternidade, ou seja, no reconhecimento de que tais direitos buscam tutelar o gênero humano e não apenas os indivíduos ou o Estado. Assim, compõem os direitos de terceira geração o direito ao desenvolvimento, à paz, ao meio ambiente, ao patrimônio comum da comunidade e o direito à comunicação. ${ }^{138}$ Para Etiene-R. Mbaya, a expressão mais adequada para os direitos de terceira geração seriam direitos de solidariedade, e justifica tal assertiva

\footnotetext{
FERREIRA FILHO, Manoel Gonçalves. Direitos humanos fundamentais. 13. ed. São Paulo: Saraiva, 2011. p. 67.

134 MIRKINE-GUÉTZÉVITCH, Boris. As novas tendências do direito constitucional. Tradução de Cândido da Mota Filho. São Paulo: Cia. Ed. Nacional, 1933. p. 151.

135 FERREIRA FILHO, Manoel Gonçalves. Direitos humanos fundamentais. 13. ed. São Paulo: Saraiva, 2011. p. 67-68.

136 Idem, ibidem, p. 71.

137 Idem, p. 75.

138 VASAK, Karel. Pour les droits de l'Homme de la troisième génération: les droits de solidarité. Leçon Inaugurale de 2 de julho de 1979, Instituto Internacional dos Direitos do Homem, Estrasburgo apud BONAVIDES, Paulo. Curso de direito constitucional. 26. ed. São Paulo: Malheiros, 2011. p. 569.
} 
afirmando que tal direito deveria compreender o dever de todo Estado considerar nas suas decisões o interesse de outros Estados, além da ajuda recíproca, seja financeira ou de outra natureza e uma coordenação de política econômica. ${ }^{139} \mathrm{Na}$ Constituição, os direitos de terceira geração encontram representação apenas nos artigos 225, referente ao meio ambiente, e 220, sobre comunicação.

Há, ainda, a terceira classificação dos direitos fundamentais, que, segundo Luiz A. D. Araújo e Vidal S. Nunes Junior, se dá a partir do enfoque jurídico positivo, de acordo com o qual se identificam os institutos jurídicos que integram os direitos fundamentais nos termos da Constituição. Assim, a classificação nessa hipótese se daria entre os direitos individuais, os coletivos, os direitos sociais, os de nacionalidade, os políticos e os partidos políticos. Para os fins deste trabalho interessa a análise da classificação como direitos coletivos, nos termos apresentados a seguir.

De acordo com Celso Antônio Pacheco Fiorillo, que analisa prioritariamente os mecanismos legais existentes para a defesa dos direitos fundamentais, estes devem ser classificados de acordo com a forma de sua tutela jurisdicional, ${ }^{140}$ ou seja, se individuais ou metaindividuais - i.e., aqueles que "pairam acima dos interesses individuais" $" 141$-, e, se classificados como metaindividuais, podem se subclassificar em difusos, coletivos ou individuais homogêneos.

Assim, os direitos difusos podem ser definidos como "transindividuais, de natureza indivisível de que sejam titulares pessoas indeterminadas e ligadas por circunstâncias de fato". ${ }^{142}$ Para que se compreenda o conceito desses direitos difusos, necessário aprofundar o entendimento sobre direitos transindividuais, que são aqueles que extrapolam os limites dos direitos individuais ${ }^{143} \mathrm{e}$, portanto, transcendem o

MBAYA, Etiene-R. Menschenrechte im Nord-Sued Verhaeltnis apud BONAVIDES, Paulo. Curso de direito constitucional. 26. ed. São Paulo: Malheiros, 2011. p. 570.

140 ARAÚJO, Luiz A. D.; NUNES JUNIOR, Vidal S. Curso de direito constitucional. 3. ed. São Paulo: Saraiva, 2003. p. 118.

141 FIORILlO, Celso Antônio Pacheco. Curso de direito ambiental brasileiro. 13. ed. São Paulo: Saraiva, 2012. p. 54.

142 Nos termos constantes do Código de Defesa do Consumidor, em seu artigo 81, inciso I.

143 FIORILlo, Celso Antônio Pacheco. Curso de direito ambiental brasileiro. 13. ed. São Paulo: Saraiva, 2012. p. 57. 
indivíduo, alcançando sua dimensão coletiva. ${ }^{144}$ Importante destacar que os direitos difusos caracterizam-se, especialmente, por sua indivisibilidade, ou seja, por não serem passíveis de apropriação por um único indivíduo e por serem compartilhados por todos, dado que incindível. Exemplo dessa modalidade de bem de natureza difusa é o ar atmosférico, que é compartilhado por todos, mas não pode pertencer exclusivamente a ninguém.

Quanto ao fato de o direito difuso caracterizar-se por seus titulares serem indeterminados, isto ocorre exatamente em função da indivisibilidade do bem difuso e da consequente impossibilidade de se determinar quem são todos os titulares daquele bem. Os direitos coletivos, que a melhor doutrina denomina stricto sensu, pois em lato sensu a expressão é utilizada para identificar de forma genérica os direitos difusos, coletivos e individuais homogêneos, podem ser definidos como os direitos transindividuais de natureza indivisível, ${ }^{145}$ porém passíveis de terem seus titulares identificados, dado que são titulares dos direitos coletivos stricto sensu os grupos, categorias ou classes de pessoas ligadas entre si ou com a parte contrária por meio de uma relação jurídica. ${ }^{146}$

Dessa maneira, embora os direitos coletivos stricto sensu tratem de direitos transindividuais indivisíveis, assim como os direitos difusos, aqueles possuem como característica principal a determinação de seus titulares, sendo admitido inclusive que se classifiquem como coletivos mesmo nas hipóteses em que em princípio não é possível identificar todos os titulares, dada a complexidade, por envolver titularidade coletiva, bastando, assim, que eles sejam identificáveis, e que se vinculem por meio de relação jurídica. Por fim, quanto aos direitos individuais homogêneos, estes podem ser definidos como direitos individuais, cuja origem decorre de um mesmo fato jurídico.

\footnotetext{
144 MANCUSO, Rodolfo de Camargo. Comentários ao Código de Proteção do Consumidor. São Paulo: Saraiva, 1991. p. 275.

145 FIORILlo, Celso Antônio Pacheco. Curso de direito ambiental brasileiro. 13. ed. São Paulo: Saraiva, 2012. p. 60.

146 Nos termos constantes do Código de Defesa do Consumidor, em seu artigo 81, inciso II.
} 
Portanto, são classificados como direitos coletivos, apesar de envolverem direitos individuais e divisíveis, por terem tutela jurisdicional coletiva. ${ }^{147}$

Uma vez apresentados os direitos coletivos lato sensu, é possível constatar que a natureza jurídica do patrimônio cultural imaterial é de fato de direito fundamental, que pode ser classificado como de segunda geração, se adotada a classificação conforme a evolução histórica ou como direito difuso ou coletivo, a depender da expressividade da manifestação cultural no território nacional e da possibilidade de identificação de seus titulares - ou não. Para Fiorillo, o patrimônio cultural, por ser integrante do meio ambiente cultural, possui natureza jurídica de direito difuso. Para os fins do presente trabalho, a partir dessa avaliação, é possível sustentar que o feixe de direitos de interesse público possui natureza jurídica de direitos difusos, enquanto o feixe de direitos coletivos possui natureza jurídica de direitos coletivos stricto sensu, uma vez que as comunidades que compõem os grupos que contribuem para o processo civilizatório nacional e que são os destinatários desses direitos, nos termos da Constituição, são formados por coletividade identificável e que se ligam entre si por meio de relação jurídica, conforme será analisado no capítulo seguinte.

Feita essa análise, necessário observar a consequência do reconhecimento de determinado direito como fundamental. Primeiramente, verifica-se que tal direito é essencial para a garantia da dignidade da pessoa humana, aqui considerados tanto os direitos individuais como os coletivos, cuja tutela seja necessária para que se alcancem os direitos do homem. Adicionalmente, constata-se, de acordo com o disposto na Constituição, que os direitos fundamentais possuem aplicação imediata, ${ }^{148}$ ou seja, independem de regulamentação para serem cumpridos e resguardados. Por esse motivo, ao se constatar que o patrimônio cultural, inclusive o imaterial, e os direitos culturais pertencem à categoria dos fundamentais, verifica-se que eles passam a viger e podem ser exercidos por seus titulares independentemente de quaisquer regulamentações.

\footnotetext{
Nos termos constantes do Código de Defesa do Consumidor, em seu artigo 81, inciso III.

148 Conforme artigo 5. ${ }^{\circ}, \S 1^{\circ}{ }^{\circ}$, da Constituição Federal.
} 
Dessa forma, a partir da análise do texto normativo, conclui-se que a Constituição reconhece o patrimônio cultural nacional como direito fundamental e, portanto, em função de sua relevância, as disposições constitucionais a esse respeito possuem aplicação imediata, a fim de proteger e garantir os direitos fundamentais a seus titulares. Note-se, ainda, que, também de acordo com a Constituição Federal, ${ }^{149}$ é concorrente entre União, Estados e Municípios a competência para legislar sobre a proteção do patrimônio cultural nacional, tamanha sua relevância pública. E, de acordo com a divisão anteriormente proposta, a partir da interpretação dos dispositivos constitucionais, existem dois feixes de direitos relacionados ao patrimônio cultural: o primeiro deles destinado a toda a sociedade para garantir, por exemplo, o direito de acesso à cultura, denominado de feixe de direitos de interesse público; o segundo se destina aos grupos indígenas, afro-brasileiros e demais grupos que contribuem para o processo civilizatório nacional, sendo estes de natureza coletiva stricto sensu, enquanto os primeiros possuem natureza de direitos difusos.

\subsection{Normas aplicáveis ao patrimônio cultural imaterial}

Após a apresentação do conceito de patrimônio cultural de acordo com o disposto na Constituição Federal, necessário aprofundar a análise das normas infraconstitucionais que regulam o tema, a fim de que se possa interpretar adequadamente a legislação vigente e identificar, inclusive, se existem outros direitos fundamentais, quais sejam os implícitos, previstos em referidos dispositivos legais, além de verificar se existem direitos morais tutelados sob o conceito de patrimônio cultural imaterial.

\subsubsection{Convênios e tratados internacionais}

A Organização Mundial da Propriedade Intelectual (OMPI) é agência especializada da ONU, criada em 1967, que possui como função a atualização e proposição de padrões internacionais para proteção das criações intelectuais em todo o

149 De acordo com o artigo 24, inciso VII, da Constituição Federal. 
mundo. ${ }^{150}$ A Organização das Nações Unidas para a Educação, a Ciência e a Cultura (Unesco) foi criada em 16 de novembro de 1945, com a função de promover a paz, após a 2. ${ }^{a}$ Guerra Mundial, a partir da cooperação intelectual entre os Estados. A Unesco também é a agência das Nações Unidas e possui atuação nas áreas de: Educação, Ciências Naturais, Ciências Humanas e Sociais, Cultura e Comunicação e Informação. No Brasil, a Unesco se estabeleceu em 1964, iniciou as atividades em 1972, priorizando a defesa à educação para todos e o desenvolvimento humano e social. Em relação à promoção da cultura, a Unesco entende que essa manifestação e identidade criativa dos povos contribuem para o respectivo desenvolvimento e convivência no mundo. ${ }^{151}$

Por esse motivo, a Unesco atua com o objetivo de elaborar e promover os necessários instrumentos normativos e atividades para a salvaguarda do patrimônio cultural, a proteção aos conhecimentos diversos e a troca entre as diversas culturas. No Brasil, a Unesco atua em parceria com as autoridades nacionais para promover ações que levem à preservação do patrimônio cultural, inclusive atuando para auxiliar na proteção do patrimônio cultural imaterial nacional. ${ }^{152}$ Ainda, mundialmente, a Unesco estabeleceu parceria com a OMPI para discutir e desenvolver normas-tipo ou diretrizes que permitissem a conciliação entre os direitos de propriedade intelectual e o direito à proteção cultural e, em 1985, aprovaram a lei-modelo para proteção das expressões de folclore contra sua exploração ilícita e outras ações prejudiciais, ali definidas como: ${ }^{153}$

[...] criações compostas por elemento característico da herança artística tradicional desenvolvida e mantida por uma comunidade do país ou por indivíduos refletindo as expectativas tradicionais artísticas de tal comunidade, em especial expressões verbais, como histórias, poesias, expressões musicais, expressões teatrais, dança e rituais e expressões tangíveis, como desenhos, pinturas, esculturas, cerâmicas, mosaicos, jóias, cestos, artefatos de madeira, roupas, instrumentos musicais e formas arquitetônicas. ${ }^{154}$

\footnotetext{
150 Disponível em: <http://www.onu.org.br/onu-no-brasil/ompi/>. Acesso em: 16 jun. 2012.

151 UNESCO. O que é, o que faz? Disponível em: <http://unesdoc.unesco.org/images/0018/001887/ 188700por.pdf>. Acesso em: 7 jul. 2012.

152 Disponível em: <http://www.onu.org.br/onu-no-brasil/unesco/>. Acesso em: 17 jun. 2012.

153 OMPI, UNESCO. Model provisions for national laws on the protection of expressions of folklore against illicit exploitation and other prejudicial actions. 1985. p. 3 e ss. Disponível em: $<$ http://www.wipo.int/export/sites/www/tk/en/documents/pdf/1982-folklore-model-provisions.pdf>. Acesso em: 17 jun. 2012.

154 Tradução nossa ao item Section 2, Protected Expressions of Folcklore, da "Model Provisions for Natuinal Laws on the Protection of Expressions of Folklore Against Illicit Exploitation and Other
} 
Importante analisar que a denominação "expressões de folclore" utilizada pelo documento da OMPI-Unesco, denominado Disposições Tipo para Leis Nacionais sobre a Proteção das Expressões de Folclore contra a Exploração Ilícita e outras ações Lesivas ("Disposições Tipo"), de 1985, tratava, em realidade, da proteção às expressões culturais artísticas (traditional artistic heritage) desenvolvidas e mantidas por comunidades, e não se estendia às demais formas de manifestação do patrimônio cultural da Nação. Veja-se, portanto, que, embora mais limitado do que o atual conceito de patrimônio cultural vigente na Constituição, o conceito de "expressões de folclore" adotado pela OMPI-Unesco, não implicava apenas manifestações culturais artísticas de autores desconhecidos, e poderia incluir também as manifestações de comunidades, perfeitamente identificáveis, ainda que não fosse possível individualizar um único autor integrante dessa comunidade, pois pelas características dessa herança cultural a criação é coletiva e intergeracional.

Nessas Disposições Tipo, a Unesco realiza importante levantamento das formas de regulação e tratamento jurídico idealizados para a proteção do patrimônio cultural, naquele momento denominado "expressões de folclore". Assim, apresenta as diferentes conceituações de folclore existente nas legislações internas e destaca a tendência de alguns países protegerem apenas as manifestações culturais de autores desconhecidos, enquanto outros, como a legislação-modelo da Tunísia de 1976, protegem tanto as manifestações de comunidades - entendidas como de autores conhecidos - quanto de autores desconhecidos. Ainda, ressalta que a tutela dessas “expressões de folclore” por meio da proteção de direitos de autor não parece ser possível, tampouco a mais adequada, pois o direito de autor exige que a originalidade seja individual, ou ao menos individualizável, enquanto a manifestação cultural é coletiva e construída de forma lenta e contínua pela troca e comunicação oral entre gerações de uma comunidade, e o prazo de proteção do direito de autor não seria longo

Prejudicial Actions". Disponível em: <http:/www.wipo.int/export/sites/www/tk/en/documents/ pdf/1982-folklore-model-provisions.pdf $>$. Acesso em: 17 jun. 2012. 
o suficiente para oferecer a tutela necessária para as especificidades da manifestação cultural. ${ }^{155}$

Ainda, as Disposições Tipo apresentam toda reflexão já realizada em âmbito internacional na tentativa de identificar qual seria o melhor mecanismo para a proteção das "expressões de folclore", e, assim, no âmbito das revisões da Convenção de Berna, na Conferência de Estocolmo, de 1967, buscou-se identificar, com a criação de um Grupo de Trabalho, qual seria o local mais adequado, dentro da convenção, para uma disposição que tratasse dos trabalhos decorrentes do folclore, lembrando que a conceituação de folclore era limitada ao patrimônio cultural artístico detido por comunidades.

Contudo, o resultado do debate internacional a esse respeito levou à decisão unânime, ${ }^{156}$ prevendo disposição apenas sobre o tratamento que deveria ser destinado às obras cuja autoria não fosse identificada, nos termos do artigo 15(4)a, constante da Convenção de Berna, ${ }^{157}$ o que inclusive poderia ser aplicado não apenas ao folclore, demonstrando que o texto a seguir transcrito acabou por não elucidar de forma satisfatória qual seria o tratamento adequado para o folclore ou os trabalhos dele decorrentes:

(a) Quanto às obras não publicadas cujo autor é de identidade desconhecida, mas, segundo tudo leva a presumir, nacional de um país da União, é reservada à legislação desse país a faculdade de designar a autoridade competente para representar esse autor e com poderes para salvaguardar e fazer valer os direitos do mesmo nos países da União (b) os países da União que realizarem essa designação de acordo com os termos dessa disposição deve notificar o Diretor-Geral [da OMPI] por meio de declaração escrita

155 OMPI, UNESCO. Model provisions for national laws on the protection of expressions of folklore against illicit exploitation and other prejudicial actions. 1985. p. 3 e ss. Disponível em: $<$ http://www.wipo.int/export/sites/www/tk/en/documents/pdf/1982-folklore-model-provisions.pdf>. Acesso em: 17 jun. 2012.

156 Registros da Conferência de Propriedade Intelectual de Estocolmo. Summary Minutes, Main Commitee I, 964 -981 e 1505-1515, 1967 apud OMPI, UNESCO. Model provisions for national laws on the protection of expressions of folklore against illicit exploitation and other prejudicial actions. 1985. p. 3 e ss. Disponível em: <http://www.wipo.int/export/sites/www/tk/en/documents/pdf /1982-folklore-model-provisions.pdf>. Acesso em: 17 jun. 2012.

157 BRASIL. Decreto n. ${ }^{\circ}$ 75.699, de 6 de maio de 1975. Disponível em: <https://www.planalto. gov.br/ccivil_03/decreto/1970-1979/d75699.htm>. Acesso em: 16 fev. 2014. 
informando sobre a autoridade designada. O Diretor General deve comunicar todos os países da União sobre esta declaração. ${ }^{158}$

A despeito do conteúdo do dispositivo anteriormente transcrito, quando da elaboração das Disposições Tipo, em 1985, ou seja, quase 20 anos depois de o artigo 15(4) da Convenção de Berna ter sido complementado com o conteúdo mencionado, não havia ocorrido qualquer notificação ao Diretor-Geral da OMPI, indicando uma autoridade nacional designada para proteger o trabalho de autores de identidade desconhecida.

É importante dizer, ainda, que as Disposições Tipo apresentam importante reflexão da OMPI-Unesco, já em 1985, no sentido de que, com o avanço dos meios tecnológicos para registros e divulgação de determinados fatos, a captação, divulgação e exploração econômica de manifestações de folclore, assim entendidas como manifestações do patrimônio cultural, estavam promovendo ampla utilização do patrimônio cultural de determinadas comunidades e culturas, sem que lhes fossem garantidos quaisquer direitos e, em especial, sem que se preocupassem se tal uso iria de qualquer modo corromper ou deturpar a manifestação de folclore junto a sua comunidade, especialmente para o caso das manifestações sagradas e rituais.

Por esse motivo, a OMPI-Unesco visualizava a necessidade de se elaborarem Disposições Tipos, a serem seguidas pelos países signatários, a fím de garantir o respeito aos direitos das comunidades das quais emanam as manifestações de folclore. E, nesse contexto, a OMPI-Unesco já concluía que, em seu entendimento, as medidas adotadas no campo do direito de autor não pareciam ser as mais adequadas para controlar a exploração comercial do folclore, pois o direito de autor trata de obras cuja produção e criatividade se fundem na contribuição individual, e até mesmo as obras plúrimas, como se verá adiante, possuem tratamento e reconhecimento de direitos de

\footnotetext{
158 Artigo 15(4) da Convenção de Berna. Disponível em: <http://www.wipo.int/treaties/en/ip/ berne/trtdocs_wo001.html\#P192_37445>. Acesso em: 17 jun. 2012.

159

OMPI, UNESCO. Model provisions for national laws on the protection of expressions of folklore against illicit exploitation and other prejudicial actions. 1985. p. 3 e ss. Disponível em: $<$ http://www.wipo.int/export/sites/www/tk/en/documents/pdf/1982-folklore-model-provisions.pdf>. Acesso em: 17 jun. 2012.
} 
forma individualizada, com prazo de proteção compatível com o período de vida de um indivíduo, enquanto as expressões de folclore, ou seja, o patrimônio cultural artístico, seguem complexo e coletivo processo de criação, que não pode ser tutelado unicamente pela perspectiva individual, tampouco pelo mesmo prazo, insuficiente no caso de sua proteção.

Por fim, as Disposições Tipo analisam a possibilidade de os direitos conexos dos intérpretes das manifestações culturais serem utilizados para fins de proteção da expressão de folclore. Contudo, conclui que, embora, de fato, seja necessária a proteção dos direitos conexos dos intérpretes quando executam canções, rituais, danças, encenações etc., tal tutela não garante a proteção às expressões de folclore em si, que ainda poderiam ser objeto de cópia de tudo o que não fosse objeto de performance. E, ainda, o prazo de proteção dos direitos conexos tampouco seria suficiente. Dessa maneira, conclui pela necessidade do desenvolvimento de um sistema sui generis ${ }^{160}$ de regulação dos direitos de propriedade intelectual sobre as expressões de folclore, assim entendido como um regime especial que institui uma proteção legal contra usos impróprios e não autorizados da manifestação de folclore.

Diante dessas importantes conclusões indicadas no citado documento de 1985, a OMPI-Unesco produziram a Lei-Modelo, denominada "Model provisions for national laws on the protection of expressions of folklore against illicit exploitation and other prejudicial actions", para regular o uso das expressões de folclore, servindo tal norma para pavimentar o caminho para a proteção sub-regional, regional e internacional da criação do folclore. ${ }^{161}$ Tal Lei-Modelo define as expressões de folclore, em seu artigo 2. ${ }^{\circ}$, como produções decorrentes da herança artística tradicional de determinada comunidade ou por indivíduos, como expressões verbais, musicais, por atuação e ainda expressões tangíveis das manifestações culturais acima relacionadas, como instrumentos musicais, artesanato, pinturas, formas arquitetônicas, entre outros.

\footnotetext{
160 OMPI, UNESCO. Model provisions for national laws on the protection of expressions of folklore against illicit exploitation and other prejudicial actions. 1985. p. 3 e ss. Disponível em: $<$ http://www.wipo.int/export/sites/www/tk/en/documents/pdf/1982-folklore-model-provisions.pdf>. Acesso em: 17 jun. 2012.

161 Para os fins deste trabalho, entendido também como manifestações culturais integrantes do patrimônio cultural imaterial.
} 
Os principais direitos definidos nessa Lei-Modelo são: necessidade de obtenção de autorização para uso comercial da expressão de folclore, indicação da origem da expressão de folclore em todos os meios em que esta vier a ser publicada e comunicada, bem como da comunidade de origem dessa expressão e/ou sua indicação geográfica e utilização da denominação "expressões" para tratar das manifestações culturais artísticas que tutela, para não as confundir com as "obras" objeto do direito de autor $^{162}$

Quanto à autorização, esta seria necessária para a utilização dessas expressões de folclore para fins de exploração econômica ou para qualquer uso fora de seu contexto tradicional, com exceção do uso para fins educacionais, do empréstimo para desenvolvimento de trabalho original a partir dessa expressão e uso para ilustração de trabalho original, se tal uso for compatível e respeitar a expressão de folclore, devendo ser obtida perante a autoridade nacional competente ou junto à própria comunidade, a depender da definição de cada Estado que viesse a adotar a Lei-Modelo. A partir das definições e entendimentos expressados pela Lei-Modelo, a Unesco, em conjunto com a OMPI, seguiu debatendo o tema e aprofundando seu entendimento a respeito das melhores formas de regulação, até que, a partir de 2002, a Unesco produziu uma declaração especificamente para tratar da diversidade cultural, seguindo-se de três convenções para tratar do patrimônio cultural, em suas diversas nuances, as quais serão adiante apresentadas.

Essa produção normativa se deu no intuito de enaltecer os objetivos da própria Unesco, de promoção da cultura e erradicação da pobreza, mas também em razão dos intensos trabalhos no âmbito da parceria OMPI e Unesco, e, provavelmente, em função de a Lei-Modelo não ter sido adotada para regulação do uso das expressões de folclore nos ordenamentos jurídicos internos, como se esperava. Assim, em 2002, a Unesco proclamou a Declaração Universal sobre a Diversidade Cultural, estabelecendo princípios que reconhecem a relevância da diversidade cultural para a dignidade da pessoa humana, ${ }^{163}$ bem como dos direitos culturais ${ }^{164}$ e a relação direta de ambos com

\footnotetext{
$\overline{162}$ Unesco; WIPO, 1985, artigo 32; e RODRIGUES JUNIOR, Edson Beas. Tutela juridical dos recursos da biodiversidade, dos conhecimentos tradicionais e do folklore: uma abordagem de desenvolvimento social. Rio de Janeiro: Elsevier, 2010. p. 51.

163 Cf. dispõe o artigo 4. ${ }^{\circ}$, “os direitos humanos, garantias da diversidade cultural: A defesa da
} 
os direitos humanos, em especial das minorias e dos povos autóctones, ${ }^{165}$ além de fixar princípios para a promoção da cultura e um plano de ação para aplicação dos princípios dessa declaração, o qual os Estados-membros comprometem-se a implementar.

Em 17 de outubro de 2003, a Unesco promoveu a elaboração de Convenção para a Salvaguarda do Patrimônio Cultural Imaterial, a qual foi internalizada no direito brasileiro por meio do Decreto n. ${ }^{\circ}$ 5.753, de 12 de abril de 2006. Ressalte-se que a terminologia adotada por essa Convenção não trata de expressões de folclore, mas sim de patrimônio cultural imaterial. A referida Convenção, partindo do pressuposto da “importância do patrimônio cultural imaterial como fonte de diversidade cultural e garantia de desenvolvimento sustentável", ${ }^{166}$ indica como seus objetivos:

(a) a salvaguarda do patrimônio cultural imaterial; (b) o respeito ao patrimônio cultural imaterial das comunidades, grupos e indivíduos envolvidos; (c) a conscientização no plano local, nacional e internacional da importância do patrimônio cultural imaterial e de seu reconhecimento recíproco; (d) a cooperação e a assistência internacionais. $^{167}$

Essa Convenção de 2003 define, em seu artigo 2. ${ }^{\circ}$, os conceitos de "patrimônio cultural imaterial" e "salvaguarda". De acordo com o referido documento,

diversidade cultural é um imperativo ético, inseparável do respeito à dignidade humana. Ela implica o compromisso de respeitar os direitos humanos e as liberdades fundamentais, em particular os direitos das pessoas que pertencem a minorias e os dos povos autóctones. Ninguém pode invocar a diversidade cultural para violar os direitos humanos garantidos pelo direito internacional, nem para limitar seu alcance".

Cf. dispõe o artigo 5. ${ }^{\circ}$, "os direitos culturais, marco propício da diversidade cultural: Os direitos culturais são parte integrante dos direitos humanos, que são universais, indissociáveis e interdependentes. O desenvolvimento de uma diversidade criativa exige a plena realização dos direitos culturais, tal como os define o artigo 27 da Declaração Universal de Direitos Humanos e os artigos 13 e 15 do Pacto Internacional de Direitos Econômicos, Sociais e Culturais. Toda pessoa deve, assim, poder expressar-se, criar e difundir suas obras na língua que deseje e, em particular, na sua língua materna; toda pessoa tem direito a uma educação e a uma formação de qualidade que respeite plenamente sua identidade cultural; toda pessoa deve poder participar na vida cultural que escolha e exercer suas próprias práticas culturais, dentro dos limites que impõe o respeito aos direitos humanos e às liberdades fundamentais".

Autóctone significa: "que é originário do lugar em que se encontra". ACADEMIA BRASILEIRA DE LETRAS. Dicionário escolar da língua portuguesa. 2. ed. São Paulo: Nacional, 2008. p. 180. Assim, povos autóctones são aqueles que se mantêm na mesma região de origem, i.e., povos que nasceram e permanecem na mesma área.

166 De acordo com o preâmbulo da referida convenção. Tradução efetuada pelo Ministério das Relações Exteriores, Brasília, 2006.

167 UNESCO, Convenção para Salvaguarda do Patrimônio Cultural Imaterial, 2003, art. 1. . 
entende-se por patrimônio cultural imaterial "as práticas, representações, expressões, conhecimentos e técnicas ${ }^{168}$ que as comunidades, os grupos e, em alguns casos, os indivíduos reconhecem como parte integrante de seu patrimônio cultural"." 169 Continuando, considera-se que o patrimônio cultural imaterial é transmitido de geração em geração, sendo recriado de forma recorrente, pelas comunidades e grupos que o desenvolvem e mantêm, a partir de sua interação com o meio ambiente. Indica, ainda, que o patrimônio cultural imaterial promove a sensação de identidade desse grupo, promovendo o respeito à diversidade cultural e à criatividade humana. ${ }^{170}$

A manifestação do patrimônio cultural imaterial, tal qual definido no artigo 1. ${ }^{\circ}$ da Convenção, pode ocorrer, como dispõe tal norma, nos campos: (i) das tradições e expressões orais, incluindo o idioma como veículo do patrimônio cultural imaterial; (ii) expressões artísticas; (iii) práticas sociais, rituais e atos festivos; (iv) conhecimentos e práticas relacionados à natureza e ao universo; e (v) técnicas artesanais tradicionais. ${ }^{171}$ Já "salvaguarda" são as medidas que buscam viabilizar o patrimônio cultural imaterial, por meio de sua identificação, preservação, promoção, valorização, transmissão e revitalização. ${ }^{172}$

Assim, conclui-se que essa Convenção, embora não trate especificamente das expressões de folclore, como a Disposição Tipo, em seu objeto prevê a salvaguarda do patrimônio cultural imaterial, que inclui em seu conceito as expressões artísticas e, portanto, também regula as expressões de folclore. Ainda, destaca-se que a referida Convenção não institui a necessidade de autorização para uso ou de indicação da origem da manifestação cultural, como o fazia a Lei-Modelo, porém é clara em determinar que os Estados-Membros deverão salvaguardar o patrimônio cultural imaterial, inclusive por meio da adoção de medidas jurídicas, técnicas, administrativas e financeiras para garantir o acesso ao patrimônio cultural imaterial,

\footnotetext{
168 Com os instrumentos, objetos, artefatos e lugares culturais que lhes são associados.

169 UNESCO, Convenção para Salvaguarda do Patrimônio Cultural Imaterial, 2003, art. 2. ${ }^{\text {, }}$, parágrafo 1.

170 Idem, ibidem, art. 2. ${ }^{\circ}$, parágrafo 1.

171 Idem, art. 2. ${ }^{\circ}$, parágrafo 1.

172 Idem, art. 2. ${ }^{\circ}$, parágrafo 1.
} 
desde que sejam respeitados os costumes que dispõem sobre o acesso a referido patrimônio.

No Brasil, a implementação dos compromissos assumidos na Convenção Unesco de 2003 vem sendo realizada pelo Instituto do Patrimônio Histórico, Artístico e Nacional (IPHAN). Para esse órgão ${ }^{173}$ a salvaguarda se traduz pelo investimento e apoio para a continuidade do bem cultural, criando os instrumentos necessários para sua transmissão e reprodução. ${ }^{174}$ Destaca-se que o IPHAN também reconhece que existem distintas formas de salvaguardar um bem, a serem definidas à luz do caso concreto, melhor compreendido durante o processo de inventário e registro. De forma exemplificativa, o IPHAN descreve algumas possíveis maneiras de salvaguarda, quais sejam a ajuda financeira a detentores identificáveis de saberes ou a organização comunitária ou a facilitação de acesso a matérias-primas, entre outras. Nota-se, assim, que o IPHAN reconhece a possibilidade de comunidades tradicionais serem beneficiadas pela conservação de seu patrimônio cultural. ${ }^{175}$

Ainda, importante destacar que a Unesco elaborou outros diplomas internacionais, também ratificados pelo Brasil e que tratam da proteção à cultura, porém com objetivos distintos daqueles previstos na Convenção para Salvaguarda do Patrimônio Cultural Imaterial. Tais normas são a Convenção sobre a Proteção do Patrimônio Mundial Cultural e Natural ${ }^{176}$ e a Convenção sobre a Proteção e Promoção da Diversidade das Expressões Culturais. ${ }^{177}$ A primeira delas trata da proteção ao patrimônio cultural em seu aspecto mais amplo, ressaltando a proteção ao patrimônio cultural material, natural e paisagístico. Já a Convenção sobre a Proteção e Promoção da

\footnotetext{
173 Conforme disposto no site do IPHAN. Disponível em: <http://portal.iphan.gov. br/portal/montarPaginaSecao.do?id=12553\&retorno=paginaIphan>. Acesso em: 13 jul. 2009.

174 De acordo com o IPHAN, "salvaguardar um bem cultural de natureza imaterial é apoiar sua continuidade de modo sustentável. É atuar no sentido da melhoria das condições sociais e materiais de transmissão e reprodução que possibilitam sua existência”. Disponível em: $<$ http://portal.iphan.gov.br/portal/montarPaginaSecao.do? $\mathrm{id}=12553 \&$ retorno=paginaIphan $>$. Acesso em: 13 jul. 2009.

175 Conforme disposto no site do IPHAN. Disponível em: <http://portal.iphan.gov.br/portal/ montarPaginaSecao.do?id=12553\&retorno=paginaIphan $>$. Acesso em: 13 jul. 2009.

176 Internalizada no direito brasileiro por meio do Decreto n. ${ }^{\circ} 80.978$, de 12 de dezembro de 1977, que promulga a Convenção sobre a Proteção do Patrimônio Mundial Cultural e Natural.

177 Internalizada no direito brasileiro por meio do Decreto n. ${ }^{\circ} 6.177$, de $1 .^{\circ}$ de agosto de 2007 , que promulga a Convenção sobre a Proteção e Promoção da Diversidade das Expressões Culturais.
} 
Diversidade das Expressões Culturais cuida da tutela das expressões culturais, que antes eram denominadas pela Unesco como expressões do folclore, as quais, em nosso entendimento, estão incluídas no conceito de patrimônio cultural imaterial definido pela Unesco e, portanto, também tuteladas pela Convenção Unesco de 2003. Assim, expressões culturais tradicionais são "aquelas resultantes da criatividade de indivíduos, grupos e sociedades e que têm um conteúdo cultural". ${ }^{178}$ Tal Convenção contribui, portanto, para a fixação de princípios a serem seguidos para uso das expressões culturais tradicionais, reforçando a necessidade de proteção das manifestações culturais, fruto da criatividade humana. ${ }^{179}$

Contudo, em função de existirem três convenções distintas da Unesco para tutelar o patrimônio cultural, o que se observa é que a abundância de textos e definições legais não tem facilitado a compreensão da regulamentação aplicável ao patrimônio cultural envolvido em determinado caso concreto, e as próprias comunidades e representantes de grupos que desenvolvem e conservam manifestações culturais possuem dificuldades ${ }^{180}$ de compreender as distintas definições de patrimônio cultural material e natural, patrimônio cultural imaterial e expressões culturais tradicionais. Isso ocorre especialmente porque, em realidade, o processo de criação dessas manifestações culturais é único, envolvendo a interação do homem com a natureza e a produção de manifestações materiais, imateriais, artísticas, científicas etc.

De todas as formas, para os fins do presente trabalho, que pretende identificar se existem direitos garantidos e aplicáveis ao patrimônio cultural imaterial

\footnotetext{
178 UNESCO, Convenção para Proteção e Promoção das Expressões Culturais Tradicionais, 2005, art. 3. ${ }^{\circ}, \S 3 .^{\circ}$.

179 Por meio do Decreto n. ${ }^{\circ} 6.177$ de 2007, foram determinados a execução e o cumprimento da Convenção sobre a Proteção e Promoção da Diversidade das Expressões Culturais, cujo instrumento de ratificação foi depositado em 16 de janeiro de 2007, perante a Unesco.

180

A esse respeito, veja manifestação de representante de comunidade que reconhece os esforços da Unesco para regular os direitos culturais, mas indica que a profusão de conceitos distintos atrapalha a compreensão e aplicação da norma, já que todos esses subconceitos integram o patrimônio cultural de uma comunidade: "We appreciate the value for WIPO of separating definitions, principles and policies in relation to traditional knowledge and traditional cultural expressions respectively. However, in our experience, for Indigenous Australians traditional knowledge and traditional cultural expressions are so closely related that they are inseparable. This notion is clearly explained by Aboriginal Art expert and former Curator of Aboriginal and Torres Strait Islander Art at the National Gallery of Australia, Wally Caruana, in his seminal text Aboriginal Art (1993, 2nd Ed. 2003)" (Patricia Adjei, Indigenous solicitor, Arts Law Centre of Australia on July 3rd 2007 at the WIPO Conference).
} 
detido por comunidades ou povos tradicionais identificáveis, constata-se que tanto a Convenção para Salvaguarda do Patrimônio Cultural quanto a Convenção para Proteção e Promoção das Expressões Culturais Tradicionais devem ser consideradas, pois integram o conceito de patrimônio cultural imaterial definido pela Constituição e auxiliam a compreensão das disposições já vigentes em nosso ordenamento jurídico para sua tutela. ${ }^{181}$ Veja-se, inclusive, que no site da OMPI há, atualmente, o reconhecimento de que o desenvolvimento do patrimônio cultural - e neste se inserem os conhecimentos tradicionais, como será apresentado adiante - ocorre de forma integrada com a relação entre homem e natureza:

Conhecimento tradicional, recursos genéticos e expressões culturais tradicionais (ECTs, ou "expressões do folclore") são bens econômicos e culturais dos povos indígenas e comunidades locais e seus países. O trabalho da OMPI identifica o papel que os princípios e sistemas da propriedade intelectual (PI) podem assumir na proteção do CT e ECTs de apropriação irregular e para gerar repartição de benefícios justa e equitativa a partir de sua comercialização e papel da PI na repartição de benefícios relativa a recursos genéticos. ${ }^{182}$

Dessa feita, verifica-se que tanto as disposições constitucionais quanto as diretrizes instituídas pelas Convenções Unesco ratificadas pelo Brasil devem ser adotadas no país no tocante à utilização, exploração, promoção e proteção do patrimônio cultural. Assim, além de as disposições constitucionais sobre o patrimônio cultural imaterial não necessitarem de regulamentação para serem aplicáveis e exigíveis, já que constituem direitos fundamentais, ainda existe o arcabouço legislativo em função

181 Contudo, importante ressaltar entendimento divergente de Edson Beas Rodrigues Junior, segundo o qual as expressões culturais tradicionais tratam da manifestação artística e não integrariam os bens tutelados pela Convenção para Salvaguarda do Patrimônio Cultural Imaterial da Unesco. Além do disposto no site da OMPI ressaltando que o patrimônio cultural artístico é regulado pela Convenção para Proteção e Promoção das Expressões Culturais Tradicionais. Disponível em: $<$ http://www.wipo.int/tk/en/folklore/>. Acesso em: 7 jun. 2012 (RODRIGUES JUNIOR, Edson Beas. Tutela juridical dos recursos da biodiversidade, dos conhecimentos tradicionais e do folklore: uma abordagem de desenvolvimento social. Rio de Janeiro: Elsevier, 2010. p. 51).

Tradução livre. Texto original: "Traditional knowledge (TK), genetic resources (GRs) and traditional cultural expressions (TCEs, or 'expressions of folklore') are economic and cultural assets of indigenous and local communities and their countries. WIPO's work addresses the role that intellectual property (IP) principles and systems can play in protecting TK and TCEs from misappropriation, and in generating and equitably sharing benefits from their commercialization and the role of IP in access to and benefit-sharing in genetic resources". Disponível em: $<$ http://www.wipo.int/tk/en/>. Acesso em: 7 jun. 2012. 
das Convenções Unesco e demais normas infraconstitucionais, que estabelecem princípios e diretrizes a serem seguidos pelo Estado para proteção e promoção do patrimônio cultural imaterial, bem como respeitados pelo particular que deseja explorar tais manifestações culturais. ${ }^{183}$

É importante ressaltar essa questão porque há, atualmente, a equivocada convicção de que ou o patrimônio cultural integraria o domínio público ou não haveria regulamentação, no ordenamento jurídico nacional, que disciplinasse o uso do patrimônio cultural imaterial, dado que somente no tocante à proteção do patrimônio cultural material existe norma de direito interno, infraconstitucional, regulamentando o artigo 216 da Constituição Federal. Ora, como já analisado até aqui, sequer haveria necessidade desse tipo de regulamentação, posto que, além de as previsões sobre patrimônio cultural serem autoaplicáveis, uma vez que o conteúdo da norma constitucional é completo e prescinde de regulamentação, ainda existem normas fruto da ratificação de convenções que regulamentam o uso do patrimônio cultural imaterial, tendo, inclusive, sido expedido decreto ${ }^{184}$ que institui o registro do patrimônio cultural imaterial, como parte da implementação dos compromissos assumidos internacionalmente em função da ratificação das Convenções Unesco.

De todas as formas, a interpretação da legislação em vigor no tocante à tutela do patrimônio cultural imaterial, que o inclui como bem em domínio público, tem contribuído para a apropriação indevida de conhecimentos, saberes e práticas tradicionais, que compõem o patrimônio cultural imaterial de comunidades tradicionais ou povos indígenas brasileiros. Trata-se, aqui, do patrimônio cultural imaterial detido por comunidades identificáveis e vivas, ainda não difundido, que integra o rol de saberes daquele grupo determinável de pessoas, e não daquelas manifestações culturais altamente conhecidas regional ou nacionalmente, cuja exploração não gerará qualquer prejuízo a seus detentores, ao revés, promoverá a manifestação cultural, permitindo que esta não caia no esquecimento.

\footnotetext{
183 Sob pena de aquele titular de direitos que se sentir lesado ingressar perante o Judiciário para buscar a tutela de seus direitos culturais garantidos constitucionalmente. 
Contudo, quando se trata das manifestações culturais imateriais ainda não difundidas, detidas por determinada comunidade, o uso e exploração irrestritos, sem que se sigam as diretrizes já existentes na legislação pátria, acabam por fragilizar tais manifestações culturais, além de as deturpar e, muitas vezes, implicar violação de crenças e rituais sacros desses povos, o que pode também gerar desrespeito a seus direitos fundamentais, a seus direitos de imagem, a seus direitos de autor, bem como a seus direitos culturais, todos constitucionalmente garantidos, sem deixar de mencionar a possibilidade de enriquecimento sem causa, por "furto intelectual", ${ }^{185}$ uma vez que não raro são obtidos direitos de propriedade intelectual sobre saberes que integram o patrimônio cultural imaterial de determinada comunidade tradicional, sem que seja revertido qualquer benefício em favor desta, a despeito da apropriação indevida. ${ }^{186}$

Destaca-se que a Convenção para Salvaguarda do Patrimônio Cultural Imaterial previu a constituição de uma base de dados no âmbito da Unesco para registro de todas as manifestações culturais presentes nos Estados-Membros e, em especial, das expressões culturais sob risco iminente. Em consulta a essa base de dados, ${ }^{187}$ foi possível identificar um caso ilustrativo das espécies de manifestações culturais que se pretende analisar no presente trabalho. Trata-se de manifestação detida pelo povo indígena Huachupaire, localizado na região amazônica sul do Peru e que fala a língua harákmbut. Esse povo possui um ritual religioso para cura, que consiste em cantar a oração, o que é feito pelo Eshuva, existindo, inclusive, cerimônia típica para a iniciação de novos cantores Eshuva. De acordo com a tradição oral desse povo, os cantores Eshuva aprendiam as canções com os próprios animais da floresta para cura e promoção de sensação de bem-estar, e as executavam sem instrumento musical, na língua harákmbut. Esse ritual é uma importante forma de perpetuação dessa língua e, pela transmissão oral, os professores ensinam as funções de cada música e seu uso para cura. Ocorre que tais canções Eshuva e todo o ritual correm risco de extinção, dado que a

\footnotetext{
185 BRANCO, Sérgio. O domínio público no direito autoral brasileiro: uma obra em domínio público. Rio de Janeiro: Lumen Juris, 2011. p. 188.

186 MILEO, Bruno Alberto P.; SOARES, Gysele A. A cultura tradicional e o direito autoral. In: SEMINÁRIO PATRIMÔNIO CULTURAL E PROPRIEDADE INTELECTUAL: PROTEÇÃO DO CONHECIMENTO E DAS EXPRESSÕES CULTURAIS TRADICIONAIS. Anais... Belém, 1315.10.2004. Organizado por Eliane Moreira, Carla Arouca Belas, Benedita Barros, Antônio Pinheiro. Belém: Cesupa/MPEG, 2005. p. 177-193.

187 Disponível em: <http://www.unesco.org/culture/ich/index.php?lg=en\&pg=00011>. Acesso em: 21 jun. 2012.
} 
transmissão de conhecimentos não vem ocorrendo, uma vez que os mais jovens, pertencentes a esse povo, não se interessam em aprender, pois não veem valor nesse conhecimento, tampouco nessa prática. Atualmente existem apenas doze cantores Eshuva. ${ }^{188}$

Veja-se, portanto, que a ausência de aplicação dos princípios previstos nas Convenções Unesco e, especialmente na Constituição Federal leva à desvalorização desse tipo de manifestações culturais, presentes também no Brasil, bem como à impossibilidade de subsistência do povo por meio da manutenção cultural. Se não houver possibilidade de o povo Huachupaire ser reconhecido como a origem dessa manifestação cultural, bem como titular de direitos sobre seus saberes e tradições e responsável por consentir ou impedir sua utilização, não haverá estímulo para a manutenção desse povo em suas áreas de origem e realizando a perpetuação dessa manifestação cultural. Observa-se que a mera documentação ou o registro das expressões culturais não garantem que elas permanecerão vivas e difundidas, e que, para a garantia da diversidade cultural, mais importante do que registrar a manifestação cultural, é garantir os meios necessários para que esta continue viva, sendo transmitida e recriada pela transmissão oral e, para tanto, ao menos a origem da manifestação deve ser reconhecida.

Até porque, no contexto dessa manifestação cultural em risco de extinção, tanto o feixe de direitos de interesse público quanto o coletivo estão sendo ameaçados: a sociedade, por correr o risco de não mais ter acesso à cultura, e o povo indígena de não ter a proteção e o reconhecimento de direitos que garantiriam a valorização e investimento em sua manutenção. Portanto, o reconhecimento de direitos aos titulares de manifestações culturais e o de que seu consentimento deve ser obtido para registro, divulgação e exploração de suas manifestações poderão gerar a valorização do patrimônio cultural que se almeja, conforme os princípios constitucionais e das convenções Unesco, estimulando sua perpetuidade, uma vez que seu valor - jurídico, como direito fundamental e até mesmo patrimonial - será reconhecido e possibilitará a subsistência por meio da dedicação à sua manutenção.

\footnotetext{
188 Disponível em: <http://www.unesco.org/culture/ich/index.php?lg=en\&pg=00011\&USL=00531>. Acesso em: 20 jun. 2012.
} 
Com o propósito de responder aos três questionamentos inicialmente apresentados, além das disposições constitucionais e das Convenções da Unesco, outras normas infraconstitucionais que tutelam o patrimônio cultural imaterial detido por comunidades ou povos tradicionais devem ser analisadas, pois também conferem direitos, especialmente relacionados aos direitos da personalidade, direitos morais de autor, bem como o domínio público que tutelam tais manifestações culturais.

\subsubsection{Demais normas que regulam o patrimônio cultural imaterial}

Além das disposições constitucionais e das Convenções da Unesco internalizadas no direito interno brasileiro, que tratam do patrimônio cultural imaterial, existem outras normas infraconstitucionais que devem ser analisadas para os fins do presente trabalho.

\subsubsection{Decreto $n .^{\circ} 3.551$, de 4 de agosto de 2000}

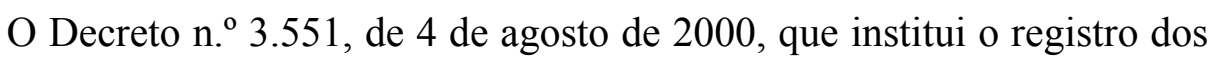
bens culturais imateriais que integram o patrimônio cultural brasileiro, foi editado como parte da implementação dos compromissos assumidos internacionalmente em função da ratificação das Convenções Unesco. Essa norma estabelece que a manifestação cultural imaterial poderá ser registrada em um dos quatro livros que institui, quais sejam o livro dos saberes, para registro dos conhecimentos e modos de fazer detidos pelas comunidades, o livro das celebrações, para o registro de festividades tradicionais, o livro das formas de expressão, para inscrever as expressões literárias, musicais, cênicas, plásticas e lúdicas, e o livro dos lugares, para registro dos locais em que as práticas culturais coletivas se reproduzem. A inscrição de uma manifestação cultural em um desses livros ocorrerá com a finalidade de que se reconheça tal expressão como "referência à continuidade histórica do bem e sua relevância nacional para a memória, a identidade e a formação da sociedade brasileira". ${ }^{189}$ No entanto, tal registro é meramente declaratório, e não constitutivo de direitos.

$\overline{189}$ Cf. artigo 1. $.^{\mathrm{o}} \S 2 .^{\mathrm{o}}$, do Decreto n..$^{\mathrm{o}} 3.551$, de 4 de agosto de 2000. 
Tal decreto determina o processo para solicitação de inscrição de determinada manifestação cultural nos referidos livros, instituindo que somente podem solicitar tal inscrição o Ministro de Estado da Cultura e as instituições vinculadas a tal Ministério, as Secretarias de Estado, Município e Distrito Federal e as sociedades ou associações civis, não sendo prevista a solicitação por parte dos próprios grupos que contribuem para o processo civilizatório nacional, dispostos na Constituição, a menos que constituam associação para os fins previstos no decreto. Essa disposição exclui o principal interessado, a comunidade ou povo tradicional, de requerer a inscrição de sua manifestação cultural perante os livros do IPHAN e não respeita a forma tradicional de organização das comunidades ou povos tradicionais, exigindo que estas formalizem associação ou outra pessoa jurídica para representá-las, ignorando o fato de que elas já podem deter seus mecanismos próprios de representatividade que deveriam ser reconhecidos e respeitados, nos termos da Política Nacional dos Povos e Comunidades Tradicionais. ${ }^{190}$

Por fim, o decreto institui, ainda, o Programa Nacional do Patrimônio Imaterial para implementar política de inventário e valorização desse patrimônio, o qual seria regulamentado em 90 dias, o que ainda não ocorreu de forma completa, dado que o Decreto n. ${ }^{\circ}$ 5.040, de 7 de abril de 2004, instituiu a estrutura regimental do IPHAN e apenas criou o Departamento do Patrimônio Imaterial (DPI), estabelecendo suas atribuições, mas não o Programa Nacional do Patrimônio Imaterial.

\subsubsection{Decreto $n .^{\circ}$ 6.884, de 7 de maio de 2009}

O referido Decreto n. ${ }^{\circ} 5.040$ foi revogado pelo Decreto n. ${ }^{\circ} 6.884$, de 7 de maio de 2009, que mantém as competências do Departamento do Patrimônio Imaterial ${ }^{191}$ e define o patrimônio cultural imaterial como "os saberes, as celebrações e

190 BRASIL. Decreto n. ${ }^{\text {o }} 6.040$, de 7 de fevereiro de 2007. Disponível em $<$ http://www.planalto.gov.br/ccivil_03/_ato2007-2010/2007/decreto/d6040.htm>. Acesso em: 4 jul. 2013.

Cf. disciplina o artigo 18 do Decreto n. ${ }^{\circ}$ 6.884/2009: “Ao Departamento do Patrimônio Imaterial compete:

I - propor diretrizes e critérios e, em conjunto com as Superintendências Estaduais, gerenciar programas, projetos e ações nas áreas de identificação, de registro, acompanhamento e valorização do patrimônio de natureza imaterial; 
as formas de expressão e lugares portadores de referência à identidade, à ação e à memória dos diferentes grupos formadores da sociedade brasileira", ${ }^{192}$ definição compatível com as disposições constitucionais e com os conceitos expressos na Convenção Unesco de 2003.

Mesmo com a existência das normas supradescritas, que claramente dispõem sobre o patrimônio cultural imaterial, verifica-se que elas instituem princípios, possibilidade de registro ou inventários. Contudo, não estabelecem aos titulares de manifestações culturais direitos oponíveis a terceiros, tampouco sanções em caso de seu descumprimento. Seria possível, a partir daí, concluir que não existem outros direitos a tutelar o patrimônio cultural imaterial de povos e comunidades tradicionais? A resposta é negativa, pois para a completa análise dos direitos incidentes sobre o patrimônio cultural imaterial não bastam as análises efetuadas até aqui, pois ainda são necessárias a avaliação da lei de direitos autorais e a realização da interpretação de todas estas normas em conformidade com a Constituição.

\subsubsection{Lei de Direitos de Autorais}

Na Lei de Direitos Autorais (LDA) ${ }^{193}$ é possível identificar dois artigos que se referem a folclore e conhecimentos étnicos e tradicionais, motivo pelo qual devem ser também analisados. O primeiro deles ${ }^{194}$ define o conceito de intérpretes ou

II - implantar, acompanhar, avaliar e difundir o Inventário Nacional de Referências Culturais, tendo em vista o reconhecimento de novos bens por meio do Registro de Bens Culturais de Natureza Imaterial;

III - acompanhar a instrução técnica e apreciar as propostas de registro de bens culturais de natureza imaterial;

IV - desenvolver, fomentar e promover estudos e pesquisas, assim como metodologias de inventário, que possibilitem ampliar o conhecimento sobre o patrimônio cultural de natureza imaterial;

$\mathrm{V}$ - propor, gerir e fomentar ações de salvaguarda de bens culturais de natureza imaterial e tornar disponíveis as informações produzidas sobre estes bens;

VI - planejar, desenvolver, fomentar e apoiar, por intermédio do Centro Nacional de Folclore e Cultura Popular, programas, projetos e ações de estudo, pesquisa, documentação e difusão das expressões das culturas populares, em nível nacional;

VII - gerenciar e executar o Programa Nacional de Patrimônio Imaterial; e

VIII - supervisionar e orientar as atividades do Centro Nacional de Folclore e Cultura Popular".

Artigo 18, parágrafo único, do Decreto n. ${ }^{\circ} 6.884 / 2009$.

193 Lei n. ${ }^{\circ} 9.610$, de 19 de fevereiro de 1998.

194 Artigo 5. ${ }^{\circ}$, inciso XIII, que define artistas intérpretes ou executantes como "todos os atores, cantores, 
executantes e, em seu conteúdo, expõe que o intérprete é aquele que representa, de qualquer forma, obras literárias, artísticas ou expressões do folclore. Portanto, dado que a LDA garante direitos conexos, reconhecendo os direitos de autor do intérprete, tem-se, de forma evidente, a proteção dos direitos de autor ao executante ou intérprete de obra folclórica.

Nesse contexto, importante destacar qual seria o conceito de “expressões de folclore” utilizado nessa norma. Dado que a LDA é de 1998, deve ser interpretada também em alinhamento com os conceitos e valores vigentes no momento em que foi elaborada, e por esse motivo folclore deve ser interpretado em consonância com as normas internacionais que discutiam a matéria. Como anteriormente exposto, nesse período as Disposições Tipo da OMPI-Unesco tratavam exatamente das diretrizes e da Lei-Modelo para disciplinar as expressões de folclore, ali entendidas como as manifestações culturais artísticas de um povo e comunidades.

Assim, entende-se que "expressões de folclore", expressão adotada pela LDA, devem ser compreendidas de acordo com a definição constante nas Disposições Tipo, ${ }^{195}$ ou seja, embora essa lei não indique quais direitos recaem sobre as expressões de folclore, registra a proteção de direito de autor a quem as interprete, seja um artista convencional ou um integrante da própria comunidade ou povo tradicional que executa uma expressão das manifestações culturais pertencentes àquele grupo. Tal previsão permite que a seguinte situação ocorra: o intérprete de determinada obra de titularidade da comunidade ou povo tradicional tenha seus direitos de autor protegidos, enquanto a expressão cultural que permitiu a interpretação não teria qualquer proteção de direito de autor.

músicos, bailarinos ou outras pessoas que representem um papel, cantem, recitem, declamem, interpretem ou executem em qualquer forma obras literárias ou artísticas ou expressões do folclore". para substituição da atual Lei n. ${ }^{\circ}$ 9610/1998, em suas distintas versões, adota "expressões culturais tradicionais", em substituição ao uso de "expressões de folclore", como é possível observar no artigo 5. ${ }^{\circ}$, XIV, da primeira versão do APL e artigo 5..$^{\circ}$ XIII, da segunda versão do APL. Demonstra-se, assim, que, com a promulgação da Convenção para Proteção e Promoção das Expressões Culturais Tradicionais, em 2005, esse passou a ser o parâmetro e o conceito utilizado pelo atual legislador. Texto do APL disponível em: <http://www.cultura.gov.br/consultadireitoautoral/consulta/>. Acesso em: 13 maio 2010 
Ainda, há outro artigo ${ }^{196}$ na LDA que trata das obras pertencentes ao domínio público, assim entendidas como as obras de autores falecidos, sem sucessores, as obras cujo prazo de proteção já tenham expirado, bem como as obras de autor desconhecido. Nesse aspecto, a LDA apresenta uma importante ressalva, destacando que, a despeito de as obras de autoria desconhecida integrarem o domínio público, excetua-se tal disposição sempre que estas referidas obras forem protegidas legalmente como conhecimento étnico e tradicional. Ou seja, a LDA reconhece haver proteção legal sobre os conhecimentos étnicos e tradicionais que obstam a integração das obras produzidas nesse contexto ao domínio público.

Retornando uma vez mais para análise do momento em que a LDA foi redigida, dado que não haviam sido elaboradas as Convenções Unesco de 2003 e 2005, para tutela do patrimônio cultural imaterial e das expressões culturais tradicionais, e que a Constituição já previa e reconhecia direitos ao patrimônio cultural dos grupos que contribuem para o processo civilizatório nacional, era a Lei-Modelo que orientava o tratamento desse tema.

Considerando o reconhecimento, na Constituição, de que as manifestações culturais de povos e comunidades tradicionais devem ser protegidas e que a Lei-Modelo indicava que deveria ser obtida autorização para uso e exploração das expressões de folclore de determinada comunidade, natural e louvável o reconhecimento pela LDA de que as manifestações dessas comunidades e povos tradicionais não podem integrar o domínio público, dado que são bens culturais que pertencem a uma coletividade ainda que não seja possível a individualização dos autores, pois são inerentes ao processo de desenvolvimento da manifestação cultural a complexidade e, não raro, a impossibilidade de se identificarem os autores, ainda que se reconheça a comunidade em que a manifestação cultural foi criada.

Assim, em nosso entendimento, a LDA reconhece que o patrimônio cultural de comunidades ou povos tradicionais identificáveis não integra o domínio

\footnotetext{
196 “Art. 45. Além das obras em relação às quais decorreu o prazo de proteção aos direitos patrimoniais, pertencem ao domínio público:

I - as de autores falecidos que não tenham deixado sucessores;

II - as de autor desconhecido, ressalvada a proteção legal aos conhecimentos étnicos e tradicionais."
} 
público e somente aquele patrimônio que de fato já esteja difundido, em esfera nacional e regional, a tal ponto que não seja mais possível identificar seu vínculo ou relação com comunidade ou povo tradicional específicos, estaria em domínio público. ${ }^{197}$ A esse respeito, importante compreender as consequências de determinada obra sair do domínio privado e integrar o domínio público, o que ocorre, normalmente, com as obras cujo prazo de proteção se encerrou. Tal processo visa motivar o autor a criar, protegendo o seu direito e dos seus sucessores sobre a obra por tempo suficiente para recuperar os investimentos despendidos para a criação com a exploração exclusiva de sua obra. ${ }^{198}$

De outro lado, ao integrar o domínio público, a obra poderá ser objeto de obras derivadas, sem necessidade de autorização junto ao autor ou seus sucessores e sem que lhes faça jus o recebimento de quaisquer valores por suposto direito patrimonial. ${ }^{199}$ Contudo, os direitos morais persistem existindo sobre a obra, ainda que caída em domínio público, de tal sorte que o autor da obra derivada deverá seguir fazendo referência à autoria da obra originária, permanecendo os direitos de integridade da obra, reivindicação de autoria, por quem tenha legitimidade, a qualquer tempo, e denominação da obra, cabendo ao Estado a defesa da integridade e autoria da obra caída em domínio público. ${ }^{200}$ Inclusive, de acordo com Roberto Senise Lisboa, a obra pertencente ao domínio público pode, ainda, ser objeto de exploração econômica, desde que tal uso não seja contrário à manifestação de vontade e intelectual de seu autor. ${ }^{201}$

197 LISBOA, Roberto Senise. A obra de folclore e sua proteção. In: BITTAR, Eduardo C. B.; CHINELLATO, Silmara Juny (Coord.). Estudos de direito de autor, direito da personalidade, direito do consumidor e danos morais: homenagem ao Professor Carlos Alberto Bittar. Rio de Janeiro: Forense Universitária, 2002. p. 73. O autor sustenta que o folclore pertence ao domínio público, ainda que decorrente do conhecimento étnico e tradicional, mas deve ser protegido, reconhecendo que não existe norma adequada no ordenamento jurídico nacional para tratar dessa proteção e sugerindo que as obras oriundas da tradição cultural sejam protegidas como direitos intelectuais, sujeitas ao regime de direito de autor cujo titular é desconhecido, cabendo a defesa dessas obras à sociedade de sua origem.

CHAVES, Antônio. Direitos de autor: princípios fundamentais. Rio de Janeiro: Forense, 1987. p. 20.

LISBOA, Roberto Senise. A obra de folclore e sua proteção. In: BITTAR, Eduardo C. B.; CHINELLATO, Silmara Juny (Coord.). Estudos de direito de autor, direito da personalidade, direito do consumidor e danos morais: homenagem ao Professor Carlos Alberto Bittar. Rio de Janeiro: Forense Universitária, 2002. p. 55. 
Assim, embora a partir da interpretação da LDA seja possível entender que o patrimônio cultural imaterial possui proteção autônoma e não integra o domínio público, ainda que se pudesse sustentar que as manifestações culturais de povos e comunidades tradicionais pertencem ao domínio público, mesmo assim seriam reconhecidos e protegidos os direitos morais do patrimônio cultural imaterial.

\subsubsection{Portaria Funai $n^{\circ}{ }^{\circ}$ 177, de 16 de fevereiro de 2006}

Por fim, importante destacar a existência de portaria da Funai n. ${ }^{\circ}$ 177/PRES, de 16 de fevereiro de 2006, que dispõe sobre direitos autorais coletivos e direitos de imagem coletivos indígenas. Relevante dizer que, apesar de as normas aplicáveis aos povos indígenas não serem objeto de análise no presente trabalho, dada a relevância das disposições da Portaria n. ${ }^{\circ}$ 177, que acaba por criar dois novos institutos, do direito de imagem coletivo e do direito autoral coletivo, seu conteúdo deve ser analisado não como norma aplicável exclusivamente aos povos indígenas, mas sim como norma que institui uma proposta de regulamentação legal que poderia interferir na tutela de todo o patrimônio cultural brasileiro.

O Presidente da Fundação Nacional do Índio expediu, em 16 de fevereiro de 2006, a Portaria n. ${ }^{0} 177$ para estabelecer que, para a realização de atividades de uso e exploração de imagens, sons, grafismos, criações e obras indígenas há a obrigatoriedade de se obter autorização ${ }^{202}$ perante a Funai. Como condição para a

CHINELLATO, Silmara Juny (Coord.). Estudos de direito de autor, direito da personalidade, direito do consumidor e danos morais: homenagem ao Professor Carlos Alberto Bittar. Rio de Janeiro: Forense Universitária, 2002. p. 55.

202 Art. 12. Os pedidos de autorização de entrada em terra indígena para a realização de atividades de uso e exploração de imagens, sons, grafismos, criações e obras indígenas, bem como os pedidos de acompanhamento pela Fundação Nacional do Índio - FUNAI das referidas atividades, serão endereçados ao Presidente da Fundação Nacional do Índio - FUNAI devendo ser instruídos com:

a) qualificação dos interessados; b) plano de trabalho com a descrição das atividades a serem desenvolvidas; c) identificação da terra indígena em que se pretende ingressar; d) datas de início e término das atividades; e) detalhamento da finalidade e usos dos materiais de autoria indígena; f) certidão negativa de pendências com a Fundação Nacional do Índio - FUNAI; g) previsão de mecanismos de redução de impactos que resultem prejudiciais aos índios e sua coletividade; $h$ ) contrato de cessão de direitos ou de autorização parcial de uso de imagens, sons, grafismos e outras obras e criações indígenas, firmado em língua portuguesa ou indígena, entre os titulares do direito e interessados, de acordo com a Legislação em vigor e com previsão de reparação de danos; e i) ou termo de compromisso firmado entre a Fundação Nacional do Índio - FUNAI e a empresa 
concessão de tal autorização, a parte interessada deve apresentar contrato de cessão de direitos ou de autorização parcial de uso de imagens, sons, grafismos e outras obras e criações indígenas, firmado em língua portuguesa ou indígena, entre os titulares do direito (povo indígena) e a parte interessada, entre outras exigências. Ocorre que a citada Portaria enfatiza e justifica a necessidade de tal contrato para atender ao direito de imagem coletivo, ${ }^{203}$ bem como aos direitos autorais coletivos ${ }^{204}$ detidos pelo povo indígena, definido como autor de determinada obra de direito autoral coletivo. Parece, em realidade, que referida Portaria trata dos direitos culturais dos povos indígenas, pois reconhece que há um direito cultural coletivo que precisa ser tutelado. Contudo, o faz de maneira confusa e não reconhecendo que se refere, em realidade, ao patrimônio cultural imaterial, protegendo as obras coletivamente criadas pela comunidade ou povo tradicional por meio dos novos institutos do direito autoral coletivo e direito de imagem coletivo.

No tocante ao direito autoral, constata-se a existência de legislação infraconstitucional específica para tratar dos direitos de autor e conexos, sendo tal norma aplicável - em princípio - a autores identificáveis, mesmo na hipótese de obra coletiva, em que há um autor responsável pela organização da obra e outros coautores identificáveis. A esse respeito, importante considerar que os direitos morais de autor, mesmo na hipótese de autores não identificáveis, devem ser tutelados e garantidos, $a d$ aeternum, ${ }^{205}$ dado que são direitos da personalidade, inclusive na hipótese de se tratar de pessoa jurídica autora. ${ }^{206}$

jornalística, no caso de autorização de atividade jornalística e prestação de serviços de informação, com anuência da comunidade.

Portaria FUNAI n. ${ }^{\circ}$ 177/2006, art. 5. ${ }^{\circ}, \S$ 3..$^{\text {. }}$ "Quando o uso da imagem de pessoas afetar a moral, os costumes, a ordem social ou a ordem econômica da coletividade, extrapolando a esfera individual, tratar-se-á de direito de imagem coletivo".

Portaria FUNAI n. ${ }^{\circ} 177 / 2006$, art. $2 .^{\circ}, \S 1 .^{\circ}$ : "O autor da obra, no caso de direito individual indígena, ou a coletividade, no caso de direito coletivo, detêm a titularidade do direito autoral e decidem sobre a utilização de sua obra, de protegê-la contra abusos de terceiros, e de ser sempre reconhecido como criador".

LISBOA, Roberto Senise. A obra de folclore e sua proteção. In: BITTAR, Eduardo C. B.; CHINELLATO, Silmara Juny (Coord.). Estudos de direito de autor, direito da personalidade, direito do consumidor e danos morais: homenagem ao Professor Carlos Alberto Bittar. Rio de Janeiro: Forense Universitária, 2002. p. 54 
Dessa maneira, como será adiante exposto, a tutela desses direitos de autores coletivos e não identificáveis, protegidos pela Constituição, quando detidos por povos e comunidades tradicionais, passa a ser identificável - neste trabalho denominados feixe de direitos coletivos -, e tal tutela deve ser realizada por meio dos direitos culturais relativos ao patrimônio cultural, sendo garantidos os direitos de personalidade coletivos, ${ }^{207}$ como será detalhado adiante, desse grupo identificável.

Adicionalmente, ainda que a Portaria $n .^{\circ} 177$ busque tutelar direitos legítimos, de povos ou comunidades tradicionais, a criação de novos institutos jurídicos, como "direito autoral coletivo" e "direito de imagem coletivo", causa contradição com os conceitos próprios de patrimônio cultural imaterial e não encontram respaldo na Constituição ou em lei. De todo modo, ainda que não concordemos com os novos institutos criados por meio dessa Portaria, tal norma corrobora a constatação de que existem direitos às comunidades e povos tradicionais titulares de manifestações culturais e chega até mesmo a reconhecer a existência de direitos morais no âmbito do citado direito autoral coletivo.

Portanto, o presente trabalho objetiva, por meio da interpretação dos institutos já existentes no ordenamento jurídico brasileiro conforme a própria Constituição, ${ }^{208}$ identificar os direitos sobre o patrimônio cultural imaterial, relacionados ao segundo feixe de direitos anteriormente definido, destinados às comunidades e povos tradicionais, identificáveis e vivos.

\subsection{A tutela pelo Instituto do Patrimônio Histórico e Artístico Nacional e a ação declaratória de descumprimento de preceito fundamental}

No Brasil, o Instituto de Patrimônio Histórico e Artístico Nacional (IPHAN) é responsável pela proteção ao patrimônio cultural desde 1937, em razão da Lei n. ${ }^{\circ}$ 378, de 13 de janeiro de 1937. Nessa época, o IPHAN visava meramente a

\footnotetext{
207 DRUMMOND, Victor Gameiro. A tutela jurídica das expressões culturais tradicionais. 2001. Tese (Mestrado) - Universidade de Lisboa, Faculdade de Direito, Lisboa, p. 204-205. No prelo. comunidade, feitas a partir da sua própria cultura e que constituem seu patrimônio cultural.
} 
proteção dos monumentos históricos. Em consonância com o princípio normativo atualmente previsto no mencionado artigo 216 da Constituição, o escopo de atuação do IPHAN aumentou em função de o conceito de patrimônio cultural ter sido ampliado. ${ }^{209}$ Dentre as competências do IPHAN está o registro de bens culturais de natureza imaterial que constituem patrimônio cultural brasileiro, em um de seus quatro livros Livro de Registro dos Saberes, Livro de Registro das Celebrações, Livro de Registro das Formas de Expressão e Livro de Registro dos Lugares. Para a realização do registro, o IPHAN observará a continuidade histórica da manifestação cultural, bem como sua relevância para a memória, a identidade e a formação da sociedade brasileira.

Por fim, ressalta-se que esse decreto institui, no âmbito do Ministério da Cultura, o "Programa Nacional do Patrimônio Imaterial", visando a implementação de política específica de inventário e valorização desse patrimônio, pretendendo, ainda, viabilizar projetos de identificação, reconhecimento, salvaguarda e promoção da dimensão imaterial do patrimônio cultural. Tal programa busca fomentar a identificação e a salvaguarda do patrimônio cultural por meio, inclusive, de parcerias com instituições dos governos federal, estadual e municipal, universidades, organizações não governamentais, agências de desenvolvimento e organizações privadas ligadas à cultura e a pesquisa. ${ }^{210}$

Em função do exposto, verifica-se que o processo, para promover o patrimônio cultural, deve seguir os princípios, diretrizes e parcerias previstos no Programa Nacional do Patrimônio Imaterial e no decreto mencionado anteriormente, envolvendo o Estado na proteção e promoção desse patrimônio cultural, especialmente porque a legislação brasileira estabelece como compromisso do Estado documentar, proteger e promover o Patrimônio Cultural.

Mesmo diante dos aparentes avanços na tutela do patrimônio cultural imaterial, o IPHAN, por meio de sua então representante, a Procuradora-geral da República (PGR) Sandra Cureau, ajuizou no Supremo Tribunal Federal (STF) a

\footnotetext{
Conforme evolução histórica traçada no item 2.1, supra.

210 Conforme disposto no site do IPHAN. Disponível em: < http://portal.iphan.gov.br/portal/ montarDetalheConteudo.do?id=12689\&sigla=Institucional\&retorno=detalheInstitucional $>$. Acesso em: 13 jul. 2009.
} 
Arguição de Descumprimento de Preceito Fundamental (ADPF) n. ${ }^{\circ}$ 206/2010, por entender que a interpretação jurisprudencial do artigo $1 .^{\circ}$ do Decreto-lei n. ${ }^{\circ}$ 25/1937, que organiza a proteção do Patrimônio Histórico e Artístico Nacional, está em desconformidade com a Constituição Federal de 1988. Com a ação, a PGR busca nova interpretação do dispositivo, no sentido de incluir no enunciado da norma o conceito amplo de bem cultural, conforme os artigos 215 e 216 da Carta Magna vigente. De acordo com a PGR, não mais deve prevalecer o entendimento antiquado jurisprudencial de que apenas os sítios e as paisagens de valor estético ou atrelados à história nacional devem ser objeto de proteção patrimonial. Além disso, no entendimento da PGR, a Constituição de 1988 ampliou o conceito de patrimônio cultural, mas, a contrario sensu, tal conceito prevalece sendo interpretado à luz do previsto no artigo $1 .^{\circ}$ do Decreto-lei n. ${ }^{\text {o }} 25 / 1937$ e, por isso, englobaria apenas o tratamento excepcional do valor do bem cultural.

Para a procuradora-geral "o que importa, agora, é a atenção especial que se dá à cultura material e imaterial dos grupos sociais formadores da sociedade", 211 para que se valorize não apenas o bem estético, mas o conteúdo do patrimônio vinculado à identidade e valorização de um grupo, de uma comunidade, de um povo que compõe a sociedade brasileira, isto é, para que se protejam os bens culturais e históricos, em função também de sua relevância como conhecimentos, crenças e tradições. Por esse motivo a PGR pede ao Supremo que julgue a ADPF procedente, para interpretar o artigo $1 .^{\circ}$ do Decreto-lei n. ${ }^{o}$ 25/1937 de maneira conforme com os artigos 215 e 216 da Constituição, de modo a incluir a proteção patrimonial dos bens imateriais.

Essa discussão provocada pelo IPHAN indica que na percepção desse órgão, para que os direitos e obrigações previstos na Constituição Federal sejam garantidos, devem existir ajustes na forma de interpretação dos dispositivos infralegais que tutelam o patrimônio cultural imaterial. Neste trabalho, a partir da análise das disposições constitucionais e das demais normas que regem a matéria em conformidade com o Texto Constitucional, objetiva-se identificar se existem direitos morais no patrimônio cultural imaterial, a fim de se interpretar e aplicar os direitos já previstos no

\footnotetext{
211 Disponível em: <http://noticias.pgr.mpf.gov.br/noticias/noticias-do-site/copy_of_constitucional/ imprimir?\&UID=8d92565857a6463060ba5cdf84dd752c\&keepThis=true\&TB iframe $=$ true \&height $=$ 400\&width=700>. Acesso em: 20 jun. 2012.
} 
ordenamento jurídico para tutela do patrimônio cultural imaterial conforme a Constituição Federal.

\subsection{Sujeito de direitos do patrimônio cultural imaterial e objeto de tutela}

Uma vez identificadas as normas existentes no ordenamento jurídico brasileiro para regular o patrimônio cultural imaterial, bem como as definições das manifestações culturais compreendidas no conceito de patrimônio cultural imaterial, o presente trabalho pretende delimitar o objeto tutelado pelo patrimônio cultural imaterial, bem como seus sujeitos de direito, a fim de verificar se o patrimônio cultural imaterial pode ser tutelado pelo direito de autor. Para tanto, será necessária a análise de conceitos do direito de autor.

No tocante ao objeto, o patrimônio cultural imaterial envolve manifestações culturais que podem ser artísticas, literárias, relacionadas aos modos de fazer viver e criar, entre outras. Todas essas manifestações culturais que integram o patrimônio cultural imaterial possuem em comum o fato de serem criações do intelecto humano, porém não se confundem com as obras do direito de autor, ${ }^{212}$ dado que não possuem autor individualizável, uma vez que são fruto de criações coletivas ao longo de gerações, baseadas na tradição e oralidade, e não permitem a identificação de seu surgimento, justamente por envolverem conhecimentos transmitidos de geração a geração ao longo do tempo.

Importante destacar que, muito embora não seja possível individualizar o autor da manifestação cultural, estas se caracterizam por serem criadas por pessoas, de forma coletiva, e por serem produzidas no bojo de comunidades, em alguns casos identificáveis - que são as manifestações cuja análise nos interessa no presente trabalho - e em outros não mais passíveis de identificação. Sob essa ótica, Victor Drummond

212 DRUMMOND, Victor Gameiro. A tutela jurídica das expressões culturais tradicionais. 2001. Tese (Mestrado) - Universidade de Lisboa, Faculdade de Direito, Lisboa, p. 27. No prelo. 
sustenta, inclusive, que a origem das expressões culturais tradicionais está nas coletividades, por ele denominadas de coletividades criadoras. ${ }^{213}$

Em razão de a manifestação cultural integrante do patrimônio cultural imaterial não permitir a identificação, com precisão, do momento de sua criação, tampouco de seu autor, percebe-se que esta não se amolda aos preceitos de direito de autor. Isso porque, sem a identificação de autoria, não é possível, em princípio, individualizar o titular dos direitos morais e patrimoniais decorrentes da obra. Da mesma forma, sem a identificação do momento da criação não se pode iniciar a contagem de prazo de proteção da obra, como preceitua o direito de autor. Assim, o objeto do patrimônio cultural caracteriza-se por ser impessoal - pois impossível individualizar e identificar a autoria da manifestação cultural - e atemporal -, uma vez que não se identifica o momento da criação.

Em conclusão, o objeto do patrimônio cultural imaterial possui como característica a indefinição do momento de seu surgimento, bem como o fato de se originar a partir de coletividade criadora, sem autor individualizável. Ressalte-se que até é possível, como se verá adiante, que determinada interpretação de dança ou música integrante do patrimônio cultural de uma comunidade, por um de seus membros, possa gerar a proteção dessa performance pelo direito autoral, por se tratar de direitos conexos ao indivíduo que atuou como intérprete. No entanto, tal proteção não recai sobre a dança e música em si, mas sim sobre a interpretação, dado que as músicas e danças integram o patrimônio cultural imaterial de titularidade dessa comunidade e devem ser protegidas como tal. Por esses fatores, para Victor Drummond, mais apropriado é denominar as criações integrantes do patrimônio cultural imaterial como expressões, e não como obra, ${ }^{214}$ terminologia intimamente relacionada ao Direito de Autor.

\footnotetext{
Idem, ibidem, p. 28.

214 DRUMMOND, Victor Gameiro. A tutela jurídica das expressões culturais tradicionais. 2001. Tese (Mestrado) - Universidade de Lisboa, Faculdade de Direito, Lisboa, p. 28. No prelo. No prelo. Destaca-se que esse autor utiliza em seu excelente trabalho a nomenclatura "expressões culturais tradicionais", dado que concentra sua análise nas Convenções Unesco, bem como nas expressões artísticas. Já a presente dissertação adota a terminologia patrimônio cultural imaterial por partir sua análise da Constituição Federal brasileira e por desejar tratar não apenas das manifestações artísticas, mas também dos modos de fazer, viver e criar dos povos e comunidades tradicionais.
} 
Importante observar que não é qualquer manifestação cultural que integra o patrimônio cultural de determinada comunidade ou povo tradicional. Para tanto, é necessário que a manifestação cultural tenha representatividade da comunidade ou do povo que a criou, ${ }^{215}$ e isso significa que a própria comunidade deve enxergar a manifestação cultural como relevante para a sua identificação como grupo. Ressalte-se que para a definição do objeto do patrimônio cultural os requisitos de criatividade e originalidade não são essenciais, diferentemente do que ocorre no direito de autor, uma das características das manifestações culturais, especialmente os saberes tradicionais que se classificam como conhecimentos técnicos sobre o meio ambiente e modos de fazer, viver e criar podem ser criados por diferentes povos ou comunidades de maneira assemelhada, por isso a originalidade não deve ser considerada um requisito essencial para a caracterização da expressão integrante do patrimônio cultural imaterial. Da mesma forma, a criatividade, muito embora seja essencial para as manifestações artísticas, pode não ser essencial para a caracterização de conhecimentos tradicionais que igualmente integram o patrimônio cultural imaterial.

Além de se caracterizar por representar a comunidade criadora, a manifestação cultural integrante do patrimônio cultural imaterial é disseminada e mantida por meio da tradição e da cultura oral. A tradição pode ser entendida, a partir da conceituação trazida pela Antropologia, como "um movimento coletivo atemporal e impessoal de transferência de conhecimento, mantido vivo por parcelas da sociedade, sejam identificáveis ou não". ${ }^{216}$ Por sua vez, a oralidade indica: (i) a forma como as manifestações culturais são transmitidas, pela língua e comunicação; e (ii) o instrumento para a garantia de conservação da manifestação cultural, pois esta não encontra, muitas vezes, o corpus para ser expressada, e sem fixação só pode ser mantida viva por meio da divulgação verbal e pelo registro no imaginário e memória das pessoas que integram o povo ou o grupo que cria e conserva a manifestação cultural ao longo das gerações. Assim, o fato de a manifestação cultural não ser obrigatoriamente fixada e depender da transmissão oral não é impeditivo, ao contrário, incentiva a proteção e a tutela pelo Direito.

\footnotetext{
215 Idem, ibidem, p. 32. No prelo.

216 DRUMMOND, Victor Gameiro. A tutela jurídica das expressões culturais tradicionais. 2001. Tese (Mestrado) - Universidade de Lisboa, Faculdade de Direito, Lisboa, p. 33. No prelo.
} 
Por fim, para enquadramento de manifestação cultural como patrimônio cultural imaterial é essencial que seja expressão das "culturas populares, indígenas e afro-brasileiras, e das de outros grupos participantes do processo civilizatório nacional", nos termos do artigo 215 da Constituição Federal.

Feita essa análise e já tentando responder ao questionamento apresentado no início deste trabalho sobre se o direito de autor tutelaria o patrimônio cultural imaterial, parece-nos que, por essas características particulares das criações objeto do patrimônio cultural imaterial, torna-se difícil o enquadramento destas no escopo do direito de autor, e, justamente por esse motivo, no capítulo seguinte serão analisados os conceitos de direito de autor, por exemplo, de obra coletiva, para o fim de identificar se conceitos e institutos próprios do direito de autor podem ser aproveitados na tutela ao patrimônio cultural imaterial, a despeito de todas as incompatibilidades já identificadas entre as criações de obras e de manifestações ou expressões culturais tradicionais. 


\section{Capítulo 3}

\section{A PROPRIEDADE INTELECTUAL E OS DIREITOS DA PERSONALIDADE}

Uma vez apresentados o conceito e a regulamentação do patrimônio cultural imaterial no ordenamento jurídico brasileiro, o presente trabalho objetiva avaliar se as normas aplicáveis ao direito de autor - e consequentemente ao direito da personalidade - seriam empregáveis também para regulamentar o patrimônio cultural imaterial, visando verificar se existem, no direito pátrio, normas efetivas que disponham sobre como deve se dar a tutela desse tipo de manifestação cultural detido pelas comunidades e povos tradicionais. Neste capítulo serão analisados os dispositivos e os conceitos relacionados aos direitos da personalidade e, em seguida, será apresentada a normatização relativa à propriedade intelectual, para, ao fim, avaliar o direito de autor, para que seja possível averiguar se este pode tutelar o patrimônio cultural imaterial.

\subsection{Os direitos da personalidade}

Os direitos da personalidade podem ser definidos como os direitos subjetivos da pessoa de defender o que lhe é próprio, como a vida, a integridade, a liberdade, a reputação, a honra, a imagem, a privacidade, a autoria, entre outros, conforme leciona Goffredo da Silva Teles Jr. ${ }^{217}$ Já para Daisy Gogliano ${ }^{218}$ são direitos subjetivos, decorrentes de prerrogativas concedidas pelo sistema jurídico a uma pessoa, para abarcar a proteção a todas as formas de expressão desses direitos, garantidos para uso por seu titular.

$\mathrm{Na}$ opinião de Limongi França, os direitos de personalidade são faculdades jurídicas cujo objetivo relaciona-se com diversos aspectos da própria pessoa do sujeito, seus prolongamentos e projeções. Limongi França inclusive desenvolve uma

\footnotetext{
217 TELLES JR., Goffredo da Silva. Direito subjetivo. In: FRANÇA, Rubens Limongi (Org.). Enciclopédia Saraiva do Direito. São Paulo: Saraiva, [s.d.], v. 28, p. 123.

218 GOGLIANO, Daisy. Direitos privados da personalidade. 1982. Dissertação (Mestrado) - Fadusp, passim.
} 
análise própria das dimensões dos direitos da personalidade, a seguir descrita. Carlos Alberto Bittar $^{219}$ evidencia que os direitos de personalidade, por sua vez, são aqueles oriundos da relação da pessoa consigo e, portanto, expressos no direito à vida, à imagem, à inviolabilidade do domicílio. Em definição ainda mais detalhada de Carlos Alberto Bittar, apresentada na obra específica para tratar dos direitos da personalidade, ${ }^{220}$ o autor entende que os direitos da personalidade são inatos, ${ }^{221}$ cabendo ao Estado apenas reconhecê-los em âmbito constitucional ou por meio de leis ordinárias, e, portanto, esses direitos da personalidade não se limitariam aos direitos positivados, podendo incluir outros que não estejam reconhecidos na Constituição ou campo privado.

Inclusive, esse autor explica porque a categoria de direitos morais de autor integra o conceito de direito da personalidade, e é para ele considerado inato, pois basta ser homem para que faça jus ao direito moral de autor como seu direito de personalidade. Quanto ao exercício desse direito, de fato outra condição deve ser satisfeita, qual seja a criação da obra. Contudo, mesmo que não seja exercida a criação, deve ser reconhecido o direito moral de autor se e quando ela for realizada. Interessante analogia é realizada pelo autor, sustentando que o direito de propriedade é garantido independentemente de o homem ser efetivamente proprietário. Em função dessa percepção o autor define os direitos da personalidade como:

a) os próprios [direitos] da pessoa em si (ou originários), existentes por sua natureza, como ente humano, com o nascimento; b) e os referentes às suas projeções para o mundo exterior (a pessoa como ente moral e social, ou seja, em seu relacionamento com a sociedade $)^{222}$ [os derivados].

219 BITTAR, Carlos Alberto. Direito de autor. 4. ed. atual. por Eduardo C.B. Bittar. São Paulo: Forense Universitária, 2008. p. 2.

220 BITTAR, Carlos Alberto. Os direitos da personalidade. 5. ed. rev. e atual. por Eduardo Bittar. São Paulo: Forense Universitária, 2001. p. 9.

221 Segundo ressalta Silmara Juny de Abreu Chinellato, com o que concordamos, só deve ser empregada "a palavra inato no sentido de originário, ínsito à qualidade de pessoa, e não como indicativo do termo inicial do nascimento" (Tutela civil do nascituro. São Paulo: Saraiva, 2003. p. 222).

222 BITTAR, Carlos Alberto. Os direitos da personalidade. 5. ed. rev. e atual. por Eduardo Bittar. São Paulo: Forense Universitária, 2001. p. 10. 
Para melhor compreensão dos direitos da personalidade, importante considerar a reflexão proposta por Fábio de Mattia, ${ }^{223}$ ao identificar que existem doutrinadores que sustentam que os direitos humanos seriam iguais aos direitos da personalidade, evidenciando que eles se referem aos direitos fundamentais do indivíduo em relação ao Estado, ao direito público, enquanto os direitos da personalidade se refeririam a esses mesmos direitos, mas na esfera do direito privado, ou seja, na tutela das relações entre pessoas e para evitar atentados a tais direitos praticados por outras pessoas.

Assim, para efetiva compreensão do conceito de direito da personalidade, importante esclarecer a distinção entre personalidade humana e personalidade jurídica. A personalidade humana é o conjunto de caracteres próprios da pessoa, ${ }^{224}$ sendo inata, de cada pessoa, portanto individualizada, tratando-se de mero objeto do direito (não é direito). A personalidade jurídica, por outro lado, é direito, e não seu objeto. É direito de defender o que lhe é próprio, sendo que passa a existir com o início da vida. Assim, a norma não é constitutiva da personalidade jurídica, mas apenas reconhece uma realidade (a vida) e um direito (da personalidade). A personalidade jurídica pertence a todo indivíduo humano vivo e deixa de existir quando não há mais vida. Em razão da personalidade jurídica, decorrem direitos, inclusive os direitos da personalidade. É exatamente a personalidade jurídica, e não a humana, que se analisa no presente trabalho.

Feito esse esclarecimento, dando seguimento à análise da personalidade jurídica, para Limongi França o direito da personalidade deveria ter se inserido na Parte Especial do Código Civil - e não na Geral - antes do Livro dos Direitos de Família (junto à tutela e curatela), recebendo, assim, tratamento específico e mais detalhado. A partir desse entendimento, esse autor sustenta que o direito da personalidade está classificado em três distintos aspectos, quais sejam o direito à integridade física, à integridade intelectual e à integridade moral. $\mathrm{O}$ direito à integridade física

\footnotetext{
223 DE MATTIA, Fábio M. Direitos da personalidade: aspectos gerais. Revista de Direito Civil, Imobiliário, Agrário e Empresarial, ano 2, p. 24, jan.-mar. 1978.

224 TELlES JR., Goffredo da Silva. Direito subjetivo. In: FRANÇA, Rubens Limongi (Org.). Enciclopédia Saraiva do Direito. São Paulo: Saraiva, [s.d.], v. 28, p. 9.
} 
compreenderia o direito à vida e aos alimentos, bem como o direito ao próprio corpo, vivo e morto; o direito sobre o corpo alheio, vivo e morto; e o direito sobre partes separadas do corpo, vivo e morto. Já o direito à integridade intelectual compreenderia o direito à liberdade de pensamento; o direito pessoal de autor científico; o direito pessoal de autor artístico; e o direito pessoal de inventor. Por fim, o direito à integridade moral incluiria o direito à liberdade política, civil e religiosa; o direito à honra $\mathrm{e}$ honorificência; direito ao recato, ao segredo pessoal, doméstico e profissional; direito à imagem; e direito à identidade pessoal, familiar e social.

Carlos Alberto Bittar estabelece divisão classificatória desses direitos de forma distinta da proposta por Limongi França, como direitos físicos, psíquicos e morais. Os direitos físicos compreenderiam o direito à vida, à integridade física, ao corpo, à imagem e voz. Já os direitos psíquicos incluiriam o direito à liberdade, à intimidade, à integridade psíquica e ao segredo. Por fim, os direitos morais contemplariam os direitos à identidade, à honra, ao intelecto e às criações intelectuais, assim compreendidos os direitos morais de autor. ${ }^{225}$ A partir dessas divisões classificatórias é possível vislumbrar a extensão dos direitos da personalidade, além de compreender que a tutela a tais direitos está efetivamente prevista no ordenamento jurídico nacional, aplicando-se, inclusive, conforme exposto no item anterior, ao patrimônio cultural imaterial. Vale ressalvar que para os fins do presente trabalho a análise dos direitos da personalidade que ora se realiza não possui o objetivo de conceituar, detalhar e esgotar o estudo de todos os direitos tutelados sob a rubrica de direito da personalidade, mas tão somente serão expostos os conceitos necessários para responder às três questões apresentadas no início desta dissertação.

\subsubsection{Histórico e extensão dos direitos da personalidade}

O direito da personalidade, de acordo com levantamento histórico realizado por Limongi França, ${ }^{226}$ encontra sua origem na proteção outorgada ao direito ao nome, reconhecida na legislação interna de diversos países, a partir de 1895, quando

\footnotetext{
225 BITTAR, Carlos Alberto. Os direitos da personalidade. 5. ed. rev. e atual. por Eduardo Bittar. São Paulo: Forense Universitária, 2001. p. 65.

226 LIMONGI FRANÇA, Rubens. Direitos da personalidade. Coordenadas fundamentais. Revista dos Tribunais, ano 72, v. 567, p. 9-16, jan. 1983.
} 
na Romênia foi promulgada a primeira norma que reconhecia esse direito. Em seguida, em 1900, o Código alemão também foi promulgado prevendo o direito ao nome e, em 1907, o Código suíço previa o direito à designação personativa - nome. Contudo, a partir do Código italiano de 1939 houve o reconhecimento a direitos da personalidade, e não mais apenas a proteção ao nome. ${ }^{227}$ Esse Código possuía cinco artigos disciplinando os direitos da personalidade, quais sejam direito ao nome, direito ao próprio corpo, direito ao pseudônimo e direito à imagem.

Ressalte-se que a inovação proporcionada por esse código era significativa, na medida em que se ampliou a proteção restrita ao nome para incluir o reconhecimento do direito ao próprio corpo e à imagem, especialmente considerando-se o momento histórico de sua promulgação, durante a Segunda Guerra Mundial. No direito interno, com o anteprojeto de Código Civil elaborado por Orlando Gomes em $1963,{ }^{228}$ os direitos da personalidade ganharam efetivamente corpo, ainda que o texto não tenha sido convertido em lei, uma vez que Orlando Gomes desenvolveu quinze artigos tratando especificamente dos direitos da personalidade, que serviram como fonte de direito e doutrina para a formação e concepção dos direitos da personalidade no direito nacional.

Inclusive Orlando Gomes ${ }^{229}$ sustentava a concepção de proteção da vida humana como princípio essencial para a elaboração dos dispositivos que regulavam os direitos da personalidade, inclusive como forma de viabilizar a proteção garantida constitucionalmente. Contudo, a comissão formada para elaborar o projeto de lei de Código Civil, apesar de se valer do conteúdo construído por Orlando Gomes, decidiu reduzi-lo, contribuindo para uma abordagem abreviada do tema na sua composição,

\footnotetext{
227 LIMONGI FRANÇA, Rubens. Direitos da personalidade. Coordenadas fundamentais. Revista dos Tribunais, ano 72, v. 567, p. 9-16, jan. 1983.

228 Idem, ibidem, p. 9-16.

229 De acordo com Orlando Gomes: "O primeiro e dos mais importantes objetivos do Anteprojeto é o de preservar um dos valores fundamentais de nossa civilização: o respeito à pessoa humana. Os Códigos individualistas, voltados inteiramente para o indivíduo, esqueciam a pessoa, omitindo-se diante de direitos sem os quais a personalidade do homem não encontra terreno propício à sua livre e necessária expansão. Alguns desses direitos, protegidos constitucionalmente, não tinham a sua tutela completada pela organização de um sistema de defesa contra possíveis atentados de particulares" (GOMES, Orlando. Memória justificativa do anteprojeto. DIN, 1963, p. 35 apud GOMES, Luis Roldão de Freitas. Noção de pessoa no direito brasileiro. Direitos da personalidade. Boletim da Faculdade de Direito, Coimbra, n. 69, p. 35, 1993.
} 
entre 1972 e 1975 . $^{230}$ Após tal evolução, ao menos doutrinária, no tema dos direitos da personalidade, a Constituição Federal de 1988 veio formalizar e estabelecer como fundamento do Estado Democrático de Direito a dignidade da pessoa humana.

Assim, são previstos como direitos fundamentais, i.e., tutelados pelo Estado, determinadas garantias definidas como direitos da personalidade ${ }^{231}$ no âmbito do direito privado, a fim de se promover a dignidade da pessoa humana. Primeiramente, a Constituição garante a inviolabilidade do direito à vida, da intimidade, assegurando, por conseguinte, todos os direitos necessários para tanto, tais como direito ao nome, de imagem, direito à saúde, à liberdade de credo e pensamento, liberdade de ir e vir, direito à sua criação e invenção, entre outros. Em especial, ressalta-se, ainda, a previsão de que é assegurada a inviolabilidade da intimidade, da vida privada, da honra e da imagem das pessoas, garantindo-se direito à indenização pelos danos materiais e morais ocasionados por sua violação. ${ }^{232}$

O direito à inviolabilidade da vida privada pode ser entendido não apenas como a proteção a aspectos íntimos da pessoa, mas sim de forma mais abrangente, ${ }^{233}$ a contemplar também seu contexto de relacionamento com seus familiares e amigos e seu domicílio. Ou seja, o conceito de vida privada nos termos constitucionais não inclui a vida social da pessoa ou suas atividades públicas, que poderão ser objeto de investigação e divulgação. ${ }^{234} \mathrm{O}$ direito à inviolabilidade da vida privada busca garantir sua confidencialidade, isto é, a liberdade de que poderá transcorrer tranquilamente sem intervenções, limitações ou acompanhamento por terceiros, o que é essencial para o desenvolvimento da personalidade. ${ }^{235}$ Ainda, ao se garantir o segredo da vida privada, busca-se também proibir a investigação sobre a vida íntima e familiar, bem como sua divulgação ao público, a fim de que não se limitem

\footnotetext{
$\overline{230}$ GOMES, Luis Roldão de Freitas. Noção de pessoa no direito brasileiro. Direitos da personalidade. Boletim da Faculdade de Direito, Coimbra, n. 69, p. 35, 1993.

231 Constituição Federal, artigo 5. ${ }^{\circ}$.

232 Constituição Federal, artigo 5. ${ }^{\circ}$, inciso X.

233 SILVA, José Afonso da. Comentário contextual à Constituição. 7. ed. São Paulo: Malheiros, 2010. p. 104.

234 KAYSER, Pierre. La proteción de la vie privée: protection du secret de la vie privée. Marselha: Presses Universitaires d'Aux-Marselle, 1984. p. 11.

235 SILVA, José Afonso da. Comentário contextual à Constituição. 7. ed. São Paulo: Malheiros, 2010. p. 104.
} 
direitos da personalidade. Ressalte-se que o objetivo da inviolabilidade da vida privada é garantir que qualquer pessoa possa exercer livremente sua vida privada, do modo como the convir, decidindo se deseja ou não compartilhar sua vida pessoal e familiar. ${ }^{236}$

Ainda, quanto ao direito à honra e imagem, estes são direitos independentes da personalidade, ${ }^{237}$ que não se relacionam, em princípio, com a vida privada. A honra pode ser entendida como a reputação, o bom nome, ou seja, é decisiva para a manutenção da dignidade da pessoa. ${ }^{238}$ Assim, a inviolabilidade à honra consiste no direito de qualquer pessoa preservar sua reputação e manter sua dignidade, sendo-lhe facultado manter em sigilo qualquer dado desabonador que possa comprometer sua honra. ${ }^{239}$ Já o direito à inviolabilidade da imagem se refere à proteção do aspecto físico da dignidade da pessoa, garantindo a preservação de sua aparência e até mesmo de seu desejo de isolamento e não identificação. Trata-se, na opinião de Adriano De Cupis, de uma manifestação da personalidade moral do indivíduo, ${ }^{240}$ assim como o direito à vida privada, à honra e à intimidade.

Ainda, é garantida, como direito da personalidade, a exclusividade dos autores na utilização, publicação ou reprodução de suas obras. Normalmente, esse dispositivo constitucional é interpretado exclusivamente à luz da LDA. Contudo, importa ressaltar que, como direito fundamental, tem aplicação imediata, mesmo na ausência de norma que o regulamente, e não deve ser interpretado restritivamente. Assim, muito embora a LDA discipline as condições e prazos para obtenção do direito de exclusividade, verifica-se que tal norma infraconstitucional não é clara em proteger os direitos dos autores de manifestações culturais, sejam esses identificáveis ou não, o que não significa que eles estejam desprotegidos ou que não haja regulamentação legal desses direitos. Assim, a partir da aplicação do artigo 5. $^{\circ}$, inciso XXVII, da Constituição Federal, reconhecem-se direitos aos autores, sem que se exija para tanto que tais autores

\footnotetext{
${ }^{236}$ KAYSER, Pierre. La proteción de la vie privée: protection du secret de la vie privée. Marselha: Presses Universitaires d'Aux-Marselle, 1984. p. 10-12.

237 MONREAL, Eduardo Novoa. Derecho a la vida privada y libertad de información. 2. ed. México: Siglo Veintiuno, 1981. p. 80.

238 SILVA, José Afonso da. Comentário contextual à Constituição. 7. ed. São Paulo: Malheiros, 2010. p. 104.

239 DE CUPIS, Adriano. Riservatezza e segretto (Dirrito a). Novissimo Digesto Italiano. Torino: UTET, 1969. p. 115.

240 Idem, ibidem, p. 117.
} 
sejam individualmente identificáveis, o que permite admitir que esse direito da personalidade de que "aos autores pertence o direito exclusivo de utilização, publicação ou reprodução de suas obras" 241 também poderia ser suscitado por integrante de comunidade ou povo tradicional ou, até mesmo, pela própria comunidade tradicional, para que lhe seja garantida a proteção, enquanto autora, das manifestações culturais que cria, recria e mantém vivas.

Ainda, dispõe o Texto Constitucional ${ }^{242}$ que são assegurados, nos termos da lei, a participação individual em obra coletiva, e o direito de físcalização ao autor ou intérpretes, do aproveitamento econômico das obras que criarem. Veja-se, a esse respeito, que também se reconhecem os direitos às participações individuais, o que pode ser aproveitado, independentemente de regulamentação expressa, pelas pessoas que contribuíram para a criação ou interpretação de manifestações do patrimônio cultural de determinada comunidade. A respeito da desnecessidade de regulamentação desse dispositivo, verifica-se que, embora o Texto Constitucional mencione que os citados direitos são assegurados "nos termos da lei", trata-se, mais uma vez, de direito fundamental e, portanto, com aplicação imediata, conforme menciona José Afonso da Silva, ao afirmar que tal direito não pode deixar de ser garantido a seu titular por falta de regulamento. ${ }^{243}$ Assim, para fins de aplicação desse dispositivo às comunidades e povos tradicionais na proteção de seus direitos relacionados às manifestações culturais, em caso de sua violação, poderia ser invocado o Poder Judiciário para, expondo o caso concreto, identificar os direitos violados, apresentar os danos suportados e requerer a avaliação e decisão do Poder Judiciário quanto à existência dos direitos dos membros da comunidade e desta própria como criadora e, porque não, autora de manifestações culturais, sujeita às garantias do texto constitucional para a tutela das comunidades e povos tradicionais. ${ }^{244}$

\footnotetext{
BRASIL. Constituição Federal, artigo 5. ${ }^{\circ}$, inciso XXVII.

242 BRASIL. Constituição Federal, artigo 5. ${ }^{\circ}$, inciso XXVIII.

243 SILVA, José Afonso da. Comentário contextual à Constituição. 7. ed. São Paulo: Malheiros, 2010. p. 104.

244 Idem, ibidem, p. 126.
} 


\subsubsection{Direito da personalidade de povos e comunidades tradicionais}

Uma vez relacionados os direitos fundamentais previstos constitucionalmente para defesa da personalidade humana, ${ }^{245}$ a principal decorrência desse entendimento, além de serem normas de aplicação imediata, é, de acordo com Robert Alexy, o fato de serem direitos universais, que se referem a todo ser humano, inclusive, coletividades, sempre que sejam necessários para a "realização de direitos do homem". ${ }^{246}$ Portanto, todos esses direitos garantidos ao homem também devem ser assegurados a coletividades - como comunidades tradicionais - desde que isso seja necessário para tutela dos direitos do homem. Ora, como já identificado anteriormente neste trabalho, sendo a comunidade tradicional uma extensão do indivíduo e o ambiente necessário para seu desenvolvimento cultural, verifica-se que também por esse argumento os direitos fundamentais constitucionalmente previstos e os de personalidade regulamentados no âmbito do direito privado podem ser aplicados às comunidades e povos tradicionais, resta identificar como, quais direitos e em quais circunstâncias, o que será analisado no capítulo seguinte.

Assim, identificados os direitos da personalidade e constatado que dentre estes está o direito moral e às criações intelectuais, inclusive quando o processo criativo é realizado por membros de comunidades e povos tradicionais, bem como verificado que a proteção aos direitos culturais e ao modo tradicional de vida é direito fundamental, como reconheceu a Corte Interamericana de Direitos Humanos, no caso Sawayoman versus Paraguai, de 2006, conclui-se que são conferidos direitos às comunidades e povos tradicionais sobre as manifestações culturais que tenham criado, e tais direitos são classificados como fundamentais - no que concerne ao direito de viver sob sua cultura e exercer suas práticas tradicionais -, além de serem reconhecidos como direitos da personalidade, os direitos morais garantidos aos autores sobre suas criações,-ainda que esses autores criem por meio de processos coletivos e não possam ser individualmente identificados.

\footnotetext{
245 BITTAR, Carlos Alberto. Os direitos da personalidade. 5. ed. rev. e atual. por Eduardo Bittar. São Paulo: Forense Universitária, 2001. p. 56.

246 ALEXY, Robert. Direitos fundamentais no Estado constitucional democrático. Revista de Direito Administrativo, Rio de Janeiro, Renovar, v. 217, p. 55.
} 
Uma vez verificado que o direito fundamental à vida e à saúde inclui a garantia de proteção ao direito à cultura de comunidade tradicional e ao reconhecimento de que lhe devem ser assegurados os meios para exercício de seu modo tradicional de vida, como reconheceu a decisão da Corte Interamericana de Direitos Humanos, e que o direito da personalidade garante o direito à vida, bem como o direito à honra, à imagem e direitos morais pelas criações realizadas, é possível constatar que, se não forem reconhecidos os direitos dos povos e comunidades tradicionais sobre suas manifestações culturais, haverá violação aos direitos fundamentais e de personalidade que lhe são garantidos.

Assim, seja porque na qualidade de direito fundamental cabe ao Estado garantir a proteção e reconhecimento das manifestações culturais de povos e comunidades tradicionais, seja porque na qualidade de direito da personalidade integram os direitos inatos, o patrimônio cultural imaterial de povos e comunidades tradicionais é protegido, e sua utilização ou exploração sem o consentimento de seus titulares implica atentado a seu direito fundamental à vida e a seu direito da personalidade, à honra, imagem e direitos morais sobre suas criações coletivas. Portanto, é possível concluir que existem direitos morais no patrimônio cultural imaterial, e, se estes não forem respeitados, estar-se-á violando direitos fundamentais e da personalidade.

A corroborar esse entendimento, apresenta-se a opinião de Pontes de Miranda, ${ }^{247}$ para quem o direito da personalidade seria: "O direito da personalidade como tal não é o direito sobre a própria pessoa, é o direito que se irradia do fato jurídico da personalidade".

Assim, reitera-se o pensamento de que o direito da personalidade pode ter entendimento e aplicação estendidos que não se limitam à pessoa, pois o direito da personalidade é decorrência do fato jurídico da personalidade e, portanto, pode ser destinado a pessoa jurídica ou a comunidade ou povo tradicional que detenham personalidade jurídica. A partir da análise ora realizada, é possível sustentar que os

PONTES DE MIRANDA. Direitos da personalidade. Tratado de direito privado. Rio de Janeiro: Borsoi, 1955. v. 7, p. 13 apud CHINELLATO, Silmara Juny de Abreu. Tutela civil do nascituro. São Paulo: Saraiva, 2003. p. 205. 
direitos da personalidade, usualmente caracterizados por serem aplicados a indivíduos identificáveis, podem ser reconhecidos a coletividades, como uma comunidade ou povo tradicional criador de manifestação cultural imaterial. A corroborar esse ponto de vista, o autor Victor Drummond ${ }^{248}$ sustenta que o direito da personalidade pode e deve ser entendido de maneira alargada e não aplicado exclusivamente de forma individualista. O autor afirma que o Direito deve se valer de avaliações próprias da Antropologia para que possa compreender que os entendimentos sobre o que é individual e coletivo de uma comunidade tradicional difere da visão daqueles que vivem individualmente em sociedades complexas. Assim, o referido autor assevera que o direito da personalidade, sob a ótica de uma comunidade, deve ser mais amplo para integrar e proteger a identidade e a personalidade daquela coletividade, dado que essa expressão coletiva é essencial para a tutela do indivíduo, sendo todo o grupo titular desses direitos. E conclui que, se existe uma personalidade coletiva na comunidade ou povo, haveria a possibilidade de aplicação de alguns direitos da personalidade de forma coletiva, tais como o direito à honra, à privacidade e à imagem-atributo.

Victor Drummond ainda sustenta que grupos identificáveis que possuem valores coletivos podem ter uma personalidade coletiva e, em decorrência, ter direito a algumas categorias de direito da personalidade, tais como à integridade, à moral e à imagem dessa coletividade. Isso porque, muito embora os direitos da personalidade sejam eminentemente individualistas e protejam as relações civis do indivíduo antes mesmo da existência de Estado,249 há o reconhecimento250 de que essa doutrina deve ser modernizada e aplicada além do indivíduo, tal como ocorre ao se tutelarem alguns direitos da pessoa

\footnotetext{
248 DRUMMOND, Victor Gameiro. A tutela jurídica das expressões culturais tradicionais. 2001. Tese (Mestrado) - Universidade de Lisboa, Faculdade de Direito, Lisboa, p. 197. No prelo.

249

Idem, ibidem, p. 207.

250

Conforme comprova a jurisprudência, veja-se o seguinte acórdão: "Apelação cível. Direito privado não especificado. Telefonia. Portabilidade numérica. Falha na prestação dos serviços. Danos morais. Pessoa jurídica. Falha na prestação de serviços não negada. Demonstração de que os prejuízos causados à autora, não impugnados idoneamente pela ré, foram causa de dano moral, por ofensa à sua honra objetiva, destacando-se a perda da credibilidade da empresa (agência de viagens) perante a clientela. Valor da indenização fixado na origem em $\mathrm{R} \$ 10.000,00$, não recomendando minoração ou majoração, na linha de precedentes deste colegiado e diante do caso concreto. Juros moratórios contados da citação e correção monetária a partir do arbitramento da indenização. Manutenção integral da sentença. Desprovimento do apelo e do recurso adesivo" (TJRS, Apelação Cível n. ${ }^{\circ}$ 70040610040, Rel. Des. Ana Lúcia Carvalho Pinto Vieira Rebeout, j. 05.06.2014).
} 
jurídica/coletiva como direito da personalidade, tais como o direito à imagem e honra da pessoa jurídica.251 Assim, para esse autor, esses direitos da personalidade podem ser aplicados de maneira coletiva, inclusive às comunidades tradicionais, que devem ter seu direito à honra, à imagem e moral coletivos reconhecidos e protegidos, sob pena de o grupo ter sua honra violada por terceiros alheios à coletividade. Logo, Victor Drummond conclui:

Por fim, há que se concluir pela possibilidade de aplicação de tutela jurídica às coletividades criadoras em decorrência de valores tradicionalmente relacionados e tutelados, nas sociedades complexas, pelos Direitos de Personalidade. O que é (deve ser) tutelado, de fato, são fatores que emanam de modo coletivo da coletividade criadora e que sejam representativos de valores íntimos do grupo social. ${ }^{252}$

Assim, para os fins do presente trabalho, que objetiva identificar se existem direitos morais na tutela ao patrimônio cultural imaterial, é fundamental o entendimento ora sustentado por Victor Drummond, pois, se determinadas categorias de direito da personalidade podem ser atribuídas a comunidades tradicionais, de forma coletiva, como a honra, a imagem, pode ser possível o reconhecimento de direitos morais a essas comunidades tradicionais, vivas e identificáveis, ${ }^{253}$ que criam manifestações culturais. Para avaliar a possibilidade de existência de direitos morais na tutela do patrimônio cultural imaterial, serão analisados de forma mais aprofundada os Direitos da Personalidade, bem como o Direito de Autor.

\subsection{Natureza jurídica do direito da personalidade}

Relevante ainda avaliar qual seria a natureza do direito da personalidade, se de direito positivado ou se fundada no direito natural. Para Limongi França $^{254}$ e Silmara Chinellato, ${ }^{255}$ o rol dos direitos da personalidade não é taxativo,

\footnotetext{
251 MORATO, Antonio Carlos. Direitos de autor em obra coletiva. 2.ed. São Paulo: Saraiva, 2007. p. 69. No prelo.

252 DRUMMOND, Victor Gameiro. A tutela jurídica das expressões culturais tradicionais. 2001. Tese (Mestrado) - Universidade de Lisboa, Faculdade de Direito, Lisboa, p. 203. No prelo.

253 Idem, ibidem, p. 221.

254 LIMONGI FRANÇA, Rubens. Direitos da personalidade. Coordenadas fundamentais. Revista dos Tribunais, ano 72, v. 567, p. 5, jan. 1983.
} 
posto que fundado no direito natural, mas, para Adriano De Cupis, ${ }^{256}$ trata-se de direito de natureza positiva.

$\mathrm{Na}$ medida em que os direitos da personalidade referem-se a direitos inatos, próprios da personalidade jurídica, não sendo constituídos pela norma, parece evidente que são fundados no direito natural e, portanto, não taxativos. Em sentido similar, Carlos Alberto Bittar sustenta que tais direitos são inatos e, ainda, absolutos, extrapatrimoniais, intransmissíveis e imprescritíveis, além de serem vitalícios - o que pode ser compreendido como ad aeternum para o caso dos direitos morais, por exemplo - e oponíveis erga omnes. ${ }^{257}$

Quanto à extensão, os direitos da personalidade englobam tanto o sentido estrito (pessoa em si mesma) quanto o sentido amplo (seus prolongamentos e projeções). ${ }^{258}$ Por fim, quanto à sua natureza, constata-se que os direitos da personalidade envolvem uma natureza pública, já que fundados na Constituição Federal, além de possuírem tanto natureza social - como o direito à educação, trabalho, lazer quanto natureza privada, já que preveem direitos que se relacionam aos aspectos privados da personalidade. Assim, dado que os direitos da personalidade não são, portanto, taxativos, pois fundados no direito natural, e são amplos em sua extensão, abrangendo os prolongamentos e projeções da pessoa e podem ser aplicados a comunidades tradicionais, ${ }^{259}$ é possível concluir que abarcam também os direitos coletivos relacionados ao patrimônio cultural imaterial de determinada comunidade, ou seja, aqueles direitos sobre suas crenças, valores, manifestações artísticas e culturais, que sejam essenciais à vida e identidade dos membros da comunidade e que se enquadram na divisão de Limongi França como direito à integridade física - direito à vida - e direito à integridade intelectual, às criações coletivas, realizadas de forma

\footnotetext{
255 CHINELlATO, Silmara Juny de Abreu. Tutela civil do nascituro. São Paulo: Saraiva, 2003. p. 205231.

256 DE CUPIS, Adriano. Os direitos da personalidade. Lisboa: Morais Editora, 1961. passim.

257 BITTAR, Carlos Alberto. Os direitos da personalidade. 5. ed. rev. e atual. por Eduardo Bittar. São Paulo: Forense Universitária, 2001. p. 11.

258 LIMONGI FRANÇA, Rubens. Direitos da personalidade. Coordenadas fundamentais. Revista dos Tribunais, ano 72, v. 567, p. 5, jan. 1983.

259 Conforme sustenta DRUMMOND, Victor Gameiro. A tutela jurídica das expressões culturais tradicionais. 2001. Tese (Mestrado) - Universidade de Lisboa, Faculdade de Direito, Lisboa, p. 202. No prelo.
} 
intergeracional, e na divisão de Carlos Alberto Bittar enquadram-se nos direitos morais da personalidade.

Ora, se o direito da personalidade é inato e se aplica às suas projeções, constata-se que, sendo a manifestação cultural criação essencial para a identidade da coletividade e de seus membros, verifica-se a possibilidade, tal como sustentado por Victor Drummond, ${ }^{260}$ de que haja a ampliação do escopo de aplicação dos direitos de personalidade para abarcar não apenas o indivíduo, mas também a pessoa jurídica e as comunidades tradicionais - que devem ser equiparadas a pessoas jurídicas sem a necessidade de sua constituição formal, ${ }^{261}$ em respeito a seus modos tradicionais de organização e ao reconhecimento de que sua forma tradicional de organização equivalese aos rituais para constituição de pessoa jurídica das sociedades complexas.

A partir dessa análise e considerando a primeira pergunta que se pretende responder - se existem direitos conferidos ao patrimônio cultural imaterial -, verifica-se que puderam ser identificados determinados direitos da personalidade, como direito à honra, à imagem e a direitos morais sobre as criações dos povos e comunidades tradicionais, quer porque os direitos da personalidade podem ser interpretados de forma alargada para tutelar também direitos da personalidade de comunidades ou povos tradicionais, em função das particularidades de sua organização, quer porque as comunidades e povos tradicionais podem ser equiparados a pessoas jurídicas e se a estas são reconhecidos direitos da personalidade, também às comunidades e povos tradicionais devem ser garantidos esses direitos. Contudo, para a completa resposta a esse questionamento, ainda se faz necessária a avaliação do conceito de domínio público e por esse motivo serão apresentados os conceitos de propriedade intelectual e de direitos de autor, necessários também para a resposta ao segundo e terceiro questionamentos antes propostos.

260 DRUMMOND, Victor Gameiro. A tutela jurídica das expressões culturais tradicionais. 2001. Tese (Mestrado) - Universidade de Lisboa, Faculdade de Direito, Lisboa, p. 202. No prelo.

261 DALlARI, Dalmo de Abreu. Índios, cidadania e direitos. O índio e a cidadania. São Paulo: Brasiliense, 1983. p. 19. 


\subsection{Conceito de propriedade intelectual}

Apresentado o conceito de patrimônio cultural imaterial, bem como as normas em vigor que o definem, necessário avaliar o conceito e as normas aplicáveis ao direito da propriedade intelectual, em especial ao direito de autor e às obras de autoria plúrimas, a fim de identificar se elas podem também ser aplicadas para regular o patrimônio cultural imaterial. Como conceitua Gama Cerqueira, ${ }^{262}$ a propriedade intelectual, por ele mais bem designada de propriedade imaterial, é o conjunto de direitos resultantes do trabalho intelectual e da inteligência, com o intuito de aproveitamento material de sua utilização. Para Carlos Alberto Bittar, ${ }^{263}$ que utiliza a denominação "direitos intelectuais", estes tratam da relação entre as pessoas e as coisas que criam, como expressão imaterial de seu intelecto. Assim, tal relação entre criador e criatura, por expressar o que há de mais íntimo e autêntico no homem, implicaria verdadeiro monopólio.

De acordo com a definição de propriedade imaterial trazida por João da Gama Cerqueira, ${ }^{264}$ esta compreende tanto as criações artísticas, científicas e literárias tutelada pelo direito de autor e conexos - quanto as criações industriais, como as invenções, modelos de utilidade e desenhos industriais, ${ }^{265}$ a chamada propriedade industrial. Esses direitos teriam uma vertente material, decorrente da exploração econômica do direito de exclusivo concedido pela proteção intelectual, e uma vertente moral, destinada ao reconhecimento do autor da obra como tal, sendo este um direito inerente à sua personalidade.

Ressalte-se que, quando se tratar de direito moral relacionado às obras científicas, artísticas e literárias, ${ }^{266}$ ainda haverá o direito de o autor assegurar a

262 CERQUEIRA, João da Gama. Tratado da propriedade industrial. Versão atualizada por Newton Silveira e Denis Borges Barbosa. Rio de Janeiro: Lumen Juris, 2010. p. 6.

BITTAR, Carlos Alberto. Direito de autor. 4. ed. atual. por Eduardo C.B. Bittar. São Paulo: Forense Universitária, 2008. p. 2.

264 CERQUEIRA, João da Gama. Tratado da propriedade industrial. Versão atualizada por Newton Silveira e Denis Borges Barbosa. Rio de Janeiro: Lumen Juris, 2010. p. 124.

265 Diferentemente do que sustentam outros doutrinadores, que defendem que a propriedade intelectual se referiria apenas às criações artísticas, científicas e literárias, não incluindo o campo das criações industriais.

266 Nos termos do artigo 24 da Lei n. ${ }^{\text {9 }}$ 9.610, de 19 de fevereiro de 1998. 
integridade da obra, ou de alterá-la em caso de reedição, e o direito de retirar a obra de circulação - ainda que o autor tenha alienado seus direitos patrimoniais sobre a referida obra, quando a circulação ou utilização implicarem afronta à sua reputação e imagem -, bem como o de conservar a obra inédita e o de ter acesso a exemplar único e raro da obra, quando se encontre legitimamente em poder de outrem.

Importante salientar que a propriedade industrial difere-se das criações artísticas, científicas e literárias, por estas serem expressões estéticas, ${ }^{267}$ decorrentes do direito da personalidade e que protegem o reconhecimento de autoria - portanto essenciais ao direito de autor são a identificação e o reconhecimento da autoria enquanto aquelas caracterizam-se por serem soluções técnicas para problemas próprios do campo industrial e, como sustenta Bittar, por serem "interesses materiais do homem na vida diária". 268

Assim, para Gama Cerqueira todas as criações compreendidas sob a rubrica de propriedade intelectual buscam reconhecer e garantir os direitos de seu autor sobre as criações intelectuais fruto da inteligência humana, estejam elas sob o domínio do direito do autor ou da propriedade industrial. ${ }^{269}$ Carlos Alberto Bittar sustenta, ainda, que os direitos intelectuais promovem a conciliação dos direitos pessoais do autor sobre sua criação, com os direitos patrimoniais que adquire ao possuir o direito exclusivo de exploração econômica de sua obra, explicando-se, assim, os respectivos conceitos de direitos morais (pessoais e decorrentes do ato de criação, compondo direito da personalidade) e os direitos patrimoniais (decorrentes do direito exclusivo de explorar economicamente a criação que cabe ao autor, mas que pode ser cedido).

Ainda, observa-se a distinção na relação entre a criação e o suporte que a contém no direito de autor e na propriedade industrial. No direito de autor, aquele que adquire a criação em seu suporte material apropria-se apenas do corpus e não da obra, que continua pertencendo a seu criador, o qual segue sendo identificado como autor, em

\footnotetext{
267 SILVEIRA, Newton. A propriedade intelectual e a nova Lei de Propriedade Industrial: Lei n. ${ }^{\circ} 9.279$ de 14.05.1996. São Paulo: Saraiva, 1996. passim. Universitária, 2008. p. 3. 
função dos direitos morais, ainda que ocorra a cessão de direitos patrimoniais sobre a obra. ${ }^{270}$ Já no caso das obras utilitárias do direito da propriedade industrial o adquirente da criação em seu suporte passa a deter total propriedade e controle sobre o bem adquirido, que deverá respeitar os direitos do titular da criação - tal qual o de exclusividade na exploração econômica da criação. Aliás, essa é a efetiva intenção do direito de exclusivo na propriedade industrial, qual seja além da proteção da autoria, que se garanta o direito exclusivo de exploração econômica ao titular, a fim de que ele revele sua criação e esta venha a integrar o estado da técnica, ou seja, passe a estar disponível no conhecimento coletivo ${ }^{271}$ e possa subsidiar e inspirar novas criações e desenvolvimento científico.

Feita essa distinção, importa destacar que no presente trabalho não se pretende estudar a propriedade industrial, estando a análise direcionada às criações artísticas, científicas e literárias e, portanto, ao direito de autor. Ainda, para fins de que seja possível avaliar se o patrimônio cultural imaterial é objeto de direito de autor, importa observar a relação entre criação e seu suporte material, tal como apresentado anteriormente.

\subsubsection{A natureza jurídica da propriedade intelectual}

Em função da diversidade de institutos que integram o conceito de propriedade intelectual, como antes exposto, bastante polêmica é a caracterização da sua natureza jurídica. Contudo, faz-se imprescindível precisá-la para a correta interpretação das normas que tratam sobre o tema. Primeiramente, é relevante identificar o que os direitos de propriedade intelectual buscam tutelar. Azevedo Marques ${ }^{272}$ sustenta que os direitos de propriedade intelectual buscam, por meio da concessão de privilégios, remunerar o esforço criativo e estimular o desenvolvimento de novas criações pelo autor ou inventor. Reconhece o autor que os direitos de propriedade intelectual possuem

\footnotetext{
270 BITTAR, Carlos Alberto. Direito de autor. 4. ed. atual. por Eduardo C.B. Bittar. São Paulo: Forense Universitária, 2008. p. 3.

271 CERQUEIRA, João da Gama. Tratado da propriedade industrial. Versão atualizada por Newton Silveira e Denis Borges Barbosa. Rio de Janeiro: Lumen Juris, 2010. p. 121.

272 MARQUES, João Paulo Fernandes Remédio. Propriedade intelectual e interesse público. Boletim da Faculdade de Direito de Coimbra-BFD, n. 79, p. 293-354, 2003.
} 
outras duas funções, quais sejam: estimular o investimento na produção científica, no desenvolvimento tecnológico e nas obras estéticas; e incentivar a disponibilização de informação, visando ampliar aquele conhecimento pertencente ao estado da técnica, pois para concessão de uma patente, por exemplo, exige-se a suficiência descritiva, e para o direito de autor é garantida a proteção à obra mesmo se divulgada.

Tal estímulo à divulgação de informação é da essência da propriedade intelectual, dado que, como sustenta Gama Cerqueira, uma criação nunca é produção exclusiva de seu autor, uma vez que este se insere em uma sociedade e absorve a informação e conhecimento disponíveis em sua época e que contribuem decisivamente para a sua criação. Por esse motivo, a propriedade intelectual busca também aumentar o conhecimento e informações disponíveis, de modo a constantemente ampliar o rol de dados que possam ser utilizados para novas criações. ${ }^{273}$

Ainda quanto à natureza jurídica da propriedade intelectual, tais direitos são a forma e o instrumento jurídico a permitir que a criação tenha remuneração no mercado econômico. Azevedo Marques sustenta que o direito de exclusivo per se não tem valor, mas depois (i) da criação (para direito de autor), (ii) da divulgação (para desenhos Industriais), ou (iii) do registro (para patentes ou modelos de utilidade), passa a ser possível a apropriação privada do valor que essa criação terá para o mercado. ${ }^{274}$ Nesse sentido, Karin Grau-Kuntz ${ }^{275}$ sustenta que a propriedade intelectual garante a proteção ao direito e, portanto, a possibilidade de se valer da exclusividade de uso para obter retorno patrimonial, e é o mercado quem definirá o valor de tal direito, seguindose as leis básicas da oferta e da procura.

Contudo, para Azevedo Marques a natureza jurídica da propriedade intelectual é controversa. $\mathrm{O}$ autor debate a possibilidade de ser direito sobre as coisas, com tratamento especial ("tipos autônomos" de propriedades, independentes da

273 CERQUEIRA, João da Gama. Tratado da propriedade industrial. Versão atualizada por Newton Silveira e Denis Borges Barbosa. Rio de Janeiro: Lumen Juris, 2010. p. 71-81. Faculdade de Direito de Coimbra - BFD, n. 79, p. 293-354, 2003. 
existência desse tipo no Código Civil) ou de ser direito de exclusivo ou de monopólio que demarcam as atividades reservadas exclusivamente a seus titulares. Por fim, conclui afirmando que a única certeza quanto a natureza jurídica desses direitos é que a propriedade intelectual envolve direitos subjetivos patrimoniais privados, que protegem as criações intelectuais ou de prestação empresarial, resguardadas constitucionalmente (artigo 5. ${ }^{\circ}$, inciso XXIX). ${ }^{276}$

Para Gama Cerqueira, a legislação nacional pouco auxilia na definição da natureza jurídica da propriedade intelectual, tendo dela se esquivado o legislador pátrio, ${ }^{277}$ pois não há uniformidade de terminologia no tratamento do tema tampouco princípios ou definições comuns que possam permitir a identificação da natureza dos direitos relativos à propriedade industrial, ou relativos à propriedade artística e literária.

No entanto, é certo que o legislador nacional, por diversas vezes, valeuse da palavra propriedade ${ }^{278}$ para se referir aos direitos decorrentes da propriedade intelectual, admitindo que ela pertence a seus autores. Em outros momentos, reconheceu o direito exclusivo de reprodução das criações a seus autores ou, ainda, assegurou a exclusividade de uso e o direito de impedir a exploração por terceiros, corroborando a afirmação de Gama Cerqueira de que não há uma padronização de conceitos pelo legislador, que se furtou a definir a natureza jurídica da propriedade intelectual, deixando essa tarefa aos doutrinadores.

O que se pode sustentar é que, atualmente, a Constituição Federal e a legislação infraconstitucional garantem: (i) direito exclusivo aos autores de reproduzirem sua obra; (ii) reconhecimento de autoria e de aproveitamento econômico de suas obras; (iii) privilégio temporário aos autores de inventos industriais, reconhecendo o direito de impedir terceiro de produzir e explorar o produto ou processo

\footnotetext{
276 MARQUES, João Paulo Fernandes Remédio. Propriedade intelectual e interesse público. Boletim da Faculdade de Direito de Coimbra-BFD, n. 79, p. 293-354, 2003.

277 CERQUEIRA, João da Gama. Tratado da propriedade industrial. Versão atualizada por Newton Silveira e Denis Borges Barbosa. Rio de Janeiro: Lumen Juris, 2010. p. 124.

278 A Constituição Federal de 1891 reconhecia a propriedade das invenções a seus autores, bem como o direito exclusivo de sua reprodução, reconhecendo, ainda, a propriedade sobre as marcas. A Constituição Federal de 1934 ainda complementou o conceito e previu a exclusividade de uso do nome comercial.
} 
objeto de patente; e (iv) propriedade das marcas, nome comercial e outros signos distintivos.

Por essas definições, poder-se-ia sustentar que o ordenamento jurídico tende ao reconhecimento da propriedade, especialmente a que João da Gama Cerqueira denomina de propriedade imaterial. ${ }^{279}$ Contudo, para demonstrar seu ponto de vista, o autor reconhece e apresenta as diversas correntes sobre a natureza do direito de autor e de inventor.

De acordo com Gama Cerqueira, as correntes que se contrapõem ao entendimento de que a propriedade intelectual possui natureza de propriedade são, em primeiro lugar, a que sustenta que o direito de autor seria um privilégio resultante de contrato tácito entre inventor e sociedade, concedido pelas normas ao autor a título de recompensa, e não seria conferido nenhum direito próprio ao autor, mas lhe seria outorgado o privilégio de reprodução de suas obras como forma de retribuição pelo serviço criativo prestado à sociedade, no caso de obras artísticas, ou pela revelação, pelo inventor, de sua invenção.

Essa corrente prega a negação do direito de autor e de inventor, sendo construída com foco no direito ao privilégio de exploração da invenção/criação como forma inicial de proteção aos autores e inventores e prescindia de critérios claros para a concessão dos privilégios. A segunda corrente é a que sustenta que os direitos de autor seriam patrimoniais, não os reconhecendo como propriedade, ${ }^{280}$ e a terceira corrente afirma que o direito de autor seria estritamente pessoal, ${ }^{281}$ decorrente do direito de personalidade, e seria um direito tão pessoal que justificaria o direito de inédito. Tal corrente previa que a vertente patrimonial desse direito poderia até ocorrer, mas seria incidental. Uma quarta corrente foi desenvolvida, prevendo que o direito de autor seria patrimonial e moral, pois precisava tutelar interesses pessoais e patrimoniais. ${ }^{282}$ Para João da Gama Cerqueira, por outro lado, nenhuma dessas correntes deve prevalecer,

\footnotetext{
279 CERQUEIRA, João da Gama. Tratado da propriedade industrial. Versão atualizada por Newton Silveira e Denis Borges Barbosa. Rio de Janeiro: Lumen Juris, 2010. p. 124.

281 Conforme ensina Gama Cerqueira, Kant é o precursor dessa teoria (idem, ibidem).

282 PIOLA-CASELLI, Eduardo. Codice del Diritto di Autore: commentario della nuova legge 22 aprile 1941. Torino: UTET, 1943.
} 
dado que entende que o direito de autor envolve dois direitos diversos - e não um direito com dupla natureza -, quais sejam o direito pessoal, que é o moral, e o direito de autor, que é o patrimonial.

Para Denis Barbosa, ${ }^{283}$ os direitos exclusivos sobre novas criações não retiram do público qualquer liberdade que havia anteriormente à sua constituição, eis que os elementos tornados exclusivos - técnicas, ou obras expressivas - nunca haviam sido integrados ao domínio comum, permaneciam apenas no domínio e conhecimento de seu criador. Novos ou originais, são sempre res nova, bens ainda não inseridos na economia e, portanto, tais direitos não poderiam ter natureza de monopólio. De acordo com Richard Posner, ${ }^{284}$ os direitos de propriedade intelectual são direitos de natureza de propriedade privada, sendo ressaltado pelo autor que não é a concessão de direito exclusivo de reprodução e exploração da criação que garante a existência de poder econômico. Portanto, não é a mera concessão de direitos de propriedade intelectual que assegura poder monopolístico, justificando, assim, mais uma vez, que os direitos de propriedade intelectual não possuem natureza de monopólio, mas sim propriedade privada. A Organização Mundial do Comércio seguiu o entendimento de Richard Posner e sustenta que os direitos de propriedade intelectual não implicam direitos monopolísticos ou que interferem nas regras de concorrência. ${ }^{285}$

Considerando que o direito de autor, assim como os demais direitos de propriedade intelectual, decorrem do direito natural, da natureza humana, todos têm o direito de receber - e impedir os demais de fazê-lo - os frutos decorrentes de seu trabalho, dispondo dele como desejar. Por conseguinte, por esses fundamentos, no

\footnotetext{
283 BARBOSA, Denis Borges. Uma introdução à propriedade intelectual. 2. ed. Rio de Janeiro: Lumen Juris, 2003. p. 84.

284 POSNER, Richard A. Creating a Legal Framework for Economic Development. 13 The World Bank Research Observer, 1998, p. 1-9. Disponível em: <http://siteresources.worldbank.org/ INTLAWJUSTINST/Resources/LegalFramework.pdf>. Acesso em: 10 nov. 2011.

285 "In particular, it was no longer considered that an exclusive right necessarily conferred market power. Often, there were enough substitutes in the market to prevent the holder of an intellectual property right from actually gaining market power. The availability of substitutes was an empirical question that could only be determined on a case-by-case basis. Further, even if the intellectual property right concerned generated market power, the right holder's behaviour might not necessarily constitute an abuse of a dominance. Therefore, under current standards the exercise of an intellectual property right as such was not restrained by competition law." Report (1998) of the Working Group on The Interaction Between Trade and Competition Policy to the General Council, Wt/Wgtcp/2, 8 December 1998.
} 
entendimento de Gama Cerqueira, o direito de propriedade intelectual possui natureza jurídica de direito natural de propriedade, sendo o trabalho o meio para alcançar essa propriedade.

Portanto, para Gama Cerqueira, a propriedade intelectual possui natureza jurídica de propriedade, direito exclusivo e privado, não caracterizando privilégio - a menos não na concepção própria da palavra, isto é, vantagens em benefício de certa pessoa, com exclusão de outras e derrogação do direito comum e interesse público -, tampouco monopólio, sendo direito decorrente do direito natural que, como todo direito de propriedade, importa em restrições à liberdade do comércio, indústria e aos direitos da coletividade.

Para Newton Silveira, ${ }^{286}$ a propriedade intelectual insere-se entre os direitos reais, contudo não há como negar que também se inclui nos direitos obrigacionais e de personalidade. A propriedade intelectual está, de acordo com esse autor, nos direitos de personalidade em função dos direitos de autor, que embora possuam uma faceta patrimonial, com natureza de direito de propriedade, têm uma faceta moral, que se caracteriza por ser direito de personalidade do autor. Contudo, não é só, há também o direito de personalidade que cabe ao autor, tais como o direito de paternidade e direito de inédito.

Por fim, expostos os entendimentos supra, é apropriada a apresentação da visão de Edmond Picard, ${ }^{287}$ bem como a profunda e completa análise realizada por Silmara Chinellato, ${ }^{288}$ com entendimentos a respeito da natureza jurídica da propriedade intelectual - mais bem denominados de direitos intelectuais, como se verá adiante -, que nos parecem mais apropriadas e pertinentes ao tema deste trabalho.

De acordo com Edmond Picard, haveria a necessidade da criação de uma quarta categoria de direitos, além dos direitos pessoais, reais e obrigacionais, para

\footnotetext{
286 SILVEIRA, Newton. Propriedade intelectual: propriedade industrial, direito de autor, software, cultivares, nome empresarial. 4. ed. rev. e ampl. Barueri: Manole, 2011. p. 89.

287 PICARD, Edmond. O direito puro. 2. ed. Salvador: Livraria Progresso, 1954. p. 116.

288 CHINELlATO, Silmara Juny de Abreu. Direito de autor e direitos da personalidade: reflexões à luz do Código Civil. 2008. Tese (Concurso de Professor Titular de Direito Civil) - Faculdade de Direito da Universidade de São Paulo, São Paulo, p. 104.
} 
tratar da proteção de obras intelectuais. Em sua visão, as categorias anteriormente existentes seriam insuficientes para abarcar a tutela a esses bens intelectuais, não sendo admissível sua inclusão no rol dos direitos de propriedade. E, justamente por esse motivo, esse autor sugere que não seja empregada a denominação propriedade intelectual para descrever esses direitos, mas sim direitos intelectuais, para tratar dos direitos de autor e propriedade industrial. Para Silmara Chinellato, essa denominação parece ser a mais apropriada, além de concordar com o enquadramento dos direitos de autor entre esses direitos intelectuais, pois assim se reconhece que o direito de autor é composto de forma híbrida, por direitos morais e patrimoniais, como se verá adiante.

Logo, pode-se concluir pela análise anterior que, embora haja divergência quanto à natureza jurídica da propriedade intelectual, o direito moral de autor teria natureza jurídica de direito da personalidade, como depois será aprofundado.

\subsection{Conceito de direito de autor}

A Lei n. ${ }^{\circ} 9.610$, de 19 de fevereiro de 1998 ("Lei de Direitos Autorais" - LDA), é o dispositivo que normatiza a proteção ao direito de autor, em nosso ordenamento jurídico, e define o objeto do direito de autor como "obras intelectuais protegidas as criações do espírito, expressas por qualquer meio ou fixadas em qualquer suporte, tangível ou intangível". ${ }^{289}$ A partir dessa definição é possível verificar que o objeto de proteção é a obra, e os requisitos necessários para caracterização da obra tutelada pelo direito de autor são: deve haver criação, a obra deve ser original e estética, e a obra se subdivide entre corpo místico e corpo físico. ${ }^{290}$ De acordo com Carlos Alberto Bittar, obra estética tem por característica emocionar, sensibilizar quem a observa, ${ }^{291}$ e, para que se afira a originalidade, a obra deve ser diferente, com características diversas em relação às outras já criadas. ${ }^{292}$ Nesse sentido, Silmara

\footnotetext{
289 Conforme artigo 7. ${ }^{\circ}$ da LDA.

CHINELLATO, Silmara Juny de Abreu. Direito de autor e direitos da personalidade: reflexões à luz do Código Civil. 2008. Tese (Concurso de Professor Titular de Direito Civil) - Faculdade de Direito da Universidade de São Paulo, São Paulo, p. 28.

291 BITTAR, Carlos Alberto. Verbete "obra estética”. Enciclopédia Saraiva do Direito. São Paulo: Saraiva, 1977. v. 55, p. 236. dos direitos autorais nas atividades empresariais. 2. ed. São Paulo: RT, 2001. p. 98.
} 
Chinellato $^{293}$ ensina que o direito de autor baseia-se na criação da obra e que, para tanto, o autor confere sua personalidade à criação, motivo pelo qual esse direito é dicotômico e envolve, além dos direitos patrimoniais, os direitos morais.

Partindo-se dessa premissa, verifica-se o conceito de Antônio Chaves, ${ }^{294}$ segundo o qual direito de autor são os benefícios reconhecidos ao criador de obra literária, artística ou científica, que contenha originalidade, sendo este direito composto por vertente não patrimonial, sem limitação temporal e por aspecto patrimonial, válido durante a vida do criador e por período determinado para seus sucessores. Afirma, ainda, que se reconhecem duas esferas de direitos, a moral, i.e., direito à paternidade da obra, direito de inédito entre outros e a patrimonial, que confere a seu titular o direito exclusivo de utilizar e se beneficiar da obra.

Para Silmara Juny de Abreu Chinellato, o direito de autor é:

[...] ramo do Direito privado, com autonomia científica, que tutela as criações intelectuais, dotadas de certa originalidade, exteriorizadas em suporte tangível ou intangível, compreendidas na literatura, nas artes e nas ciências, abrangendo direitos morais, ligados à personalidade do autor, e direitos patrimoniais relativos à exploração econômica da obra. ${ }^{295}$

Reconhece-se, assim, que a relação entre criador e obra é essencial para caracterização do direito de autor, que se expressa pela concessão de benefícios exclusivos - de direitos morais e de direitos patrimoniais - àquela pessoa que realiza a criação. A partir dessa definição, surge importante questão: nas situações em que não é possível precisar o criador ou o momento da criação, ainda assim haveria obra tutelada pelo direito de autor? A resposta a esse questionamento é essencial para a análise que o presente trabalho pretende realizar, afinal, a depender da resposta, poder-se-á concluir

293 CHINELlato, Silmara Juny de Abreu. Direito de autor e direitos da personalidade: reflexões à luz do Código Civil. 2008. Tese (Concurso de Professor Titular de Direito Civil) - Faculdade de Direito da Universidade de São Paulo, São Paulo, p. 25.

294

CHAVES, Antônio. Direitos de autor: princípios fundamentais. Rio de Janeiro: Forense, 1987. p. 17.

295

CHINELLATO, Silmara Juny de Abreu. Direito de autor e direitos da personalidade: reflexões à luz do Código Civil. 2008. Tese (Concurso de Professor Titular de Direito Civil) - Faculdade de Direito da Universidade de São Paulo, São Paulo, p. 25. 
que o direito de autor pode - ou não - ser aplicável à proteção do patrimônio cultural imaterial.

A partir do que dispõe a LDA, ${ }^{296}$ verifica-se que, mesmo quando a autoria da obra não é passível de identificação, esta merece tutela, ainda que limitada no âmbito do direito de autor. Assim, as obras cuja autoria é desconhecida são consideradas como obras em domínio público, o que não significa que há inexistência de tutela sobre elas, mas sim que não se identifica o titular dos direitos patrimoniais ou morais que poderia exercê-los, permanecendo ao Estado a obrigação de proteção aos direitos morais, ainda que de autor desconhecido, i.e., impedindo a apropriação indevida dessa obra. Portanto, se alguém desejar utilizar-se da obra de autoria desconhecida, deverá informar tal circunstância, de modo a evitar que se entenda que os direitos morais sobre a obra originária lhe pertencem.

A partir desse dispositivo, poder-se-ia entender que quaisquer obras cuja autoria seja desconhecida seriam de domínio público, até mesmo o patrimônio cultural imaterial. Contudo, como será avaliado no Capítulo 4, verificar-se-á se o PCI pode ser considerado obra de direito de autor e, portanto, se estaria no escopo de aplicação do artigo 45 , ou se se enquadra no conceito de "conhecimentos étnicos e tradicionais", que são claramente excetuados do escopo das obras que pertencem ao domínio público.

Justamente para que seja possível a resposta a essa questão serão apresentados adiante a natureza jurídica do Direito de Autor, assim como seu objeto, além de ser discutida a titularidade desses direitos, especialmente em obras plúrimas. Ressalte-se que o objetivo do presente trabalho não é se aprofundar sobre os diversos temas de direito de autor. Por esse motivo serão apresentados apenas os conceitos necessários para avaliação do objetivo desta dissertação, qual seja a pesquisa sobre a existência de direitos morais no patrimônio cultural imaterial, quando de titularidade de comunidades tradicionais identificáveis.

296 Especialmente como dispõe o artigo 45 da LDA. 


\subsubsection{A natureza jurídica do direito de autor}

Compreendido o conceito de direito de autor, necessário conhecer sua natureza jurídica a fim de avaliar a possibilidade de sua aplicação à tutela do patrimônio cultural imaterial. Carlos Alberto Bittar esclarece que, ao longo da história, esse direito foi ora entendido como privilégio, ora como direito de propriedade ou como direito pessoal. ${ }^{297}$ Sustenta, ainda, que, com o amadurecimento sobre o tema, refutaram-se os entendimentos extremados, uma vez que o direito de autor não se reveste puramente de direito real, pois não possui apenas vertente patrimonial, tampouco isoladamente de direitos morais, de personalidade.

O debate sobre a natureza jurídica do direito de autor de fato é controvertida, havendo correntes diversas para tratar do tema. Para Henry Jessen ${ }^{298}$ existem várias teorias que poderiam ser consideradas para definição da natureza jurídica do direito de autor, sendo destacadas principalmente cinco. A primeira delas é a teoria da propriedade, que entende que a obra seria bem móvel apropriável, da qual emanaria direito real, pertencente a seu autor, corrente essa sustentada por comercialistas, como Tullio Ascarelli. ${ }^{299}$ De acordo com o que sustenta essa corrente, o direito de autor gera direito patrimonial, havendo por seu turno, para Tullio Ascarelli, o reconhecimento de apenas um direito moral limitado e genérico de paternidade. No entanto, para essa corrente, uma vez alienados os direitos do autor, o criador deixaria de ser reconhecido como tal, não se justificando sob a ótica dessa corrente os direitos morais de autor.

Outra corrente, para esse autor, seria a teoria da personalidade, de acordo com a qual a obra é decorrência da pessoa que a criou e, portanto, tal obra não pode ser separada de seu autor, sendo extensão deste. De acordo com essa teoria, os direitos patrimoniais originados de uma obra não encontram respaldo. A terceira teoria seria a dos bens jurídicos imateriais, segundo a qual surgem entre autor e obra duas

\footnotetext{
297 BITTAR, Carlos Alberto. Direito de autor. 4. ed. atual. por Eduardo C.B. Bittar. São Paulo: Forense Universitária, 2008. p. 10.

298 JESSEN, Henry. Direitos intelectuais. Rio de Janeiro: Itaipu, 1967. p. 26.

299 ASCARELLI, Tullio. Teoría de la concurrencia y de los bienes inmateriales. Traducción de E. Verderla y L. Suáres-Llanos. Studia albornotiana. Publicaciones del Real Colegio de España en Bolonia. Barcelona: Bosh, 1970. p. 694.
} 
classes de direitos independentes e paralelos, o direito real sobre a obra e o direito de personalidade, consistente na relação entre autor e obra. A quarta teoria seria a dos direitos sobre bens intelectuais, consistindo no direito sobre as coisas incorpóreas, e a última das teorias seria a dualista, que representa, para Henry Jessen, uma harmonização entre as teorias anteriores.

Para Silmara Juny de Abreu Chinellato existem três correntes predominantes que devem ser consideradas para o estudo da natureza jurídica do direito de autor, quais sejam: a que o considera direito de propriedade; a monista, que reputa o direito de autor como um direito único, que nasce como direito da personalidade no momento da criação, dado que é o próprio autor que é refletido na obra, reconhecendo, contudo, que a titularidade sobre esse direito pode ser dividida, posteriormente, entre direito moral, destinado ao autor, e o exercício do direito patrimonial, que pode retornar ao autor finda a licença ou concessão; e a dualista, de acordo com a qual é reconhecida a dualidade do direito de autor, formado por direitos morais e patrimoniais, que não nascem no mesmo momento e que são independentes entre si.

Conforme a teoria da propriedade, o direito de autor é direito patrimonial, ${ }^{300}$ sendo assim considerado como direito uno, absoluto, que incide sobre a obra, ainda que bem imaterial, sem diferenciar o momento da criação (corpo místico) da obra em si (corpo material), e que admite apenas a existência de direito moral necessário para uso da obra, restrito ao direito de paternidade. Esse entendimento não parece ser o mais preciso para a definição da natureza jurídica do direito de autor em função de suas particularidades, afinal, para exercício do direito de propriedade no direito brasileiro, deve ser possível sua defesa erga omnes e, além disso, impedir o uso do bem se outra pessoa a toma. No caso do direito de autor, sendo a obra composta de corpo místico e mecânico, verifica-se que, uma vez publicada a obra, o conteúdo compreendido no corpo místico passa a integrar o universo de conhecimento de todas as pessoas que têm acesso à obra.

\footnotetext{
300 ASCARELli, Tullio. Teoría de la concurrencia y de los bienes inmateriales. Traducción de E. Verderla y L. Suáres-Llanos. Studia albornotiana. Publicaciones del Real Colegio de España en Bolonia. Barcelona: Bosh, 1970. p. 695.
} 
Assim, evidente que o direito de autor de propriedade não se trata, na medida em que o titular do direito de autor não pode impedir que terceiros se apropriem do corpo místico da obra, se ele, autor, decidiu publicá-la, havendo tutela apenas sobre o corpo mecânico da obra. ${ }^{301}$ A corroborar esse entendimento, veja-se o prazo de duração do direito de autor, visto que a propriedade, para bem móvel, é perpétua e transmitida por atos entre vivos ou por sucessão, salvo situações específicas que possam levar à desapropriação por utilidade pública ou aquisição da propriedade por terceiros. ${ }^{302}$ Contudo, para os direitos de autor, os direitos morais são ad aeternum e continuam existindo mesmo após a morte do autor, mas não são transferidos quer por atos entre vivos ou em função de sucessão, enquanto os direitos patrimoniais são vitalícios para os autores e caem em domínio público 70 anos após seu falecimento. No caso de direitos conexos, a proteção de direito de autor possui prazo determinado de 70 anos a partir de

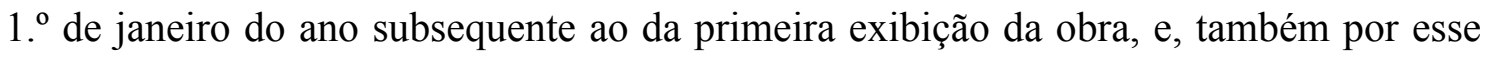
motivo, conclui-se que o direito de autor não possui natureza jurídica de propriedade.

Refutada a natureza de propriedade, necessário avaliar as outras teorias. A dualista, apresentada em 1950 por Henry Desbois, ${ }^{303}$ considera que um mesmo fato jurídico, qual seja a obra intelectual, gera dois direitos com naturezas distintas, que coexistem: um deles é o direito patrimonial, transferível e que surge a partir do momento em que há a publicação da obra - em função da possibilidade de utilização, quer por meio da reprodução, execução, entre outros -, e o outro é o direito de personalidade, de natureza personalíssima, intransferível e irrenunciável, que explica a natureza dos direitos morais de autor. Para o referido autor, a maior prova de que o direito de autor filia-se à teoria dualista é o fato de haver independência entre os direitos morais e os patrimoniais no caso da obra que passa a integrar o domínio público, pois, enquanto o direito patrimonial deixa de existir, o direito moral persiste, indicando, para esse autor, a existência de separação entre esses dois direitos.

\footnotetext{
301 CHINELlato, Silmara Juny de Abreu. Direito de autor e direitos da personalidade: reflexões à luz do Código Civil. 2008. Tese (Concurso de Professor Titular de Direito Civil) - Faculdade de Direito da Universidade de São Paulo, São Paulo, p. 75.

302 Nos termos dos artigos 5. ${ }^{\circ}$, inciso XXIV, da Constituição Federal e 1.260 e seguintes do Código Civil, respectivamente.

303 DESBOIS, Henry. Le Droit D'Auter en France. 2. ed. Paris: Dalloz, 1996. p. 238.
} 
Já a teoria monista, embora também refute a teoria da propriedade, defende que o direito de autor nasce uno, no momento da criação, como manifestação da personalidade do autor, sustentando que o direito moral é expressão do direito da personalidade em um primeiro momento, e este direito pode ser posteriormente bipartido entre direito moral e exercício do direito patrimonial. Destaque-se que o exercício do direito patrimonial somente se expressará se e quando o autor publicar a obra, reconhecendo que, se o autor se valer do direito de inédito, a faceta patrimonial do direito de autor sequer se manifestará, evidenciando, assim, o caráter único do direito de autor sustentado pela teoria monista. ${ }^{304}$

De acordo com essa teoria, há a imbricação entre direito moral e direito patrimonial de tal forma que romper a relação entre esses direitos seria impossível. Silmara Juny de Abreu Chinellato utiliza a expressão simbiose para descrever a relação de interpenetração existente entre direitos morais e patrimoniais, ${ }^{305}$ evidenciando que, quando se violam direitos morais, há consequência patrimonial e que ,quando são violados direitos patrimoniais, ocorre também violação de um direito moral. Até mesmo Carlos Alberto Bittar, defensor da teoria dualista, reconhece a relação de integração existente entre direitos morais e patrimoniais, bem como a interferência que um realiza no outro. ${ }^{306}$

Para os fins da presente dissertação, adota-se o entendimento perfilado pela Professora Silmara Juny de Abreu Chinellato, no sentido de sustentar a teoria monista para definir a natureza jurídica do direito de autor, especialmente a teoria monista personalista, ${ }^{307}$ em que se reconhece a primazia dos direitos morais - de personalidade, sobre os direitos patrimoniais. Parece-nos, de fato, que o direito de autor nasce uno, ainda que, se e quando, o autor decidir publicar a obra, encerrando o uso de

\footnotetext{
304 CHINELlato, Silmara Juny de Abreu. Direito de autor e direitos da personalidade: reflexões à luz do Código Civil. 2008. Tese (Concurso de Professor Titular de Direito Civil) - Faculdade de Direito da Universidade de São Paulo, São Paulo, p. 86.

305 Idem, ibidem, p. 102.

306 A expressão integração dos direitos morais e patrimoniais é utilizada por: BITTAR, Carlos Alberto. Direito de autor. 4. ed. atual. por Eduardo C.B. Bittar. São Paulo: Forense Universitária, 2008. p. 45.

307 CHINELlato, Silmara Juny de Abreu. Direito de autor e direitos da personalidade: reflexões à luz do Código Civil. 2008. Tese (Concurso de Professor Titular de Direito Civil) - Faculdade de Direito da Universidade de São Paulo, São Paulo, p. 86; EDELMAN, Bernard. Droit d'auteur, droits voisins. Droit dáuter et marché. Pariz: Dalloz, 1993.
} 
seu direito de inédito, o direito de autor pode ser então dividido entre direitos morais e direitos patrimoniais, os quais podem ter seu exercício ${ }^{308}$ transferido a terceiros, sem descaracterizar o fato de ser direito único, pois, findo o período para exercício desse direito patrimonial, este retornará a seu autor, caracterizando a unicidade do direito.

Contudo, também afigura-se-nos apropriada a reflexão realizada por Silmara Juny de Abreu Chinellato, ao constatar que não é de grande relevância a diferenciação conceitual estabelecida entre a corrente monista e dualista, uma vez que ambas refutam a natureza de propriedade do direito de autor e reconhecem a relevância dos direitos morais, como direito da personalidade. A grande distinção entre essas teorias reside no fato de que para a dualista há independência entre direitos morais $\mathrm{e}$ patrimoniais, e para a monista há imbricação, simbiose entre ambos, de tal forma que sua segregação seria impossível. De todo modo, ambas as teorias reconhecem que o direito de autor é composto por direito de personalidade - o direito moral - e direito patrimonial, havendo uma inquestionável inter-relação entre ambos.

Para José Carlos Costa Netto o ordenamento jurídico nacional teria incorporado a teoria dualista, uma vez que a LDA é clara ao prever a existência de direitos morais, assegurados desde logo pela Constituição, ${ }^{309}$ e patrimoniais ao autor. ${ }^{310}$ Ainda, a LDA incorporaria até mesmo a prevalência dos direitos morais sobre os patrimoniais em determinadas circunstâncias, próprio da teoria dualista, ${ }^{311}$ sempre que necessário para garantir o respeito às garantias constitucionais, isto é, para prevalência dos direitos morais como expressão dos direitos da personalidade.

Ressalte-se, por fim, que, dada a especificidade do tema e do caráter sui generis da natureza jurídica desse direito, ${ }^{312}$ Carlos Alberto Bittar, ${ }^{313}$ Giselda Maria

\footnotetext{
08 CHINELLATO, Silmara Juny de Abreu. Direito de autor e direitos da personalidade: reflexões à luz do Código Civil. 2008. Tese (Concurso de Professor Titular de Direito Civil) - Faculdade de Direito da Universidade de São Paulo, São Paulo, p. 104.

309 Constituição Federal, artigo 5. ${ }^{\circ}$, incisos XXVII e XXVIII.

310 COSTA NETTO, José Carlos. Direito autoral no Brasil. 2. ed. São Paulo: FTD, 1998. p. 77-78.

311 Idem, ibidem, p. 78-79.

312 CHINELlATO, Silmara Juny de Abreu; HIRONAKA, Giselda Maria Fernandes Novaes. Propriedade e posse: uma releitura dos ancestrais institutos. Reflexos no direito autoral. Revista do Direito Autoral da ABDA, n. 1, p. 67-68, ago. 2004.

313 BITTAR, Carlos Alberto. Direito de autor. 4. ed. atual. por Eduardo C.B. Bittar. São Paulo: Forense Universitária, 2008. p. 11-12.
} 
Fernandes Novaes Hironaka, Silmara Juny Chinellato ${ }^{314}$ e José de Oliveira Ascensão ${ }^{315}$ desenvolveram profunda análise e argumentação sustentando que os direitos de autor devem ser entendidos como direitos sui generis e tratados como ramo autônomo do direito civil, com regência específica.

Em conclusão, seguindo-se a teoria unitária, ou monista, o direito de autor seria único, contendo previsões morais, de natureza pessoal, e patrimoniais, de natureza pecuniária de maneira incindível, sendo este o entendimento que prevalece no presente trabalho e que será utilizado para compreensão e averiguação dos direitos morais eventualmente incidentes sobre as manifestações culturais integrantes do patrimônio cultural imaterial.

\subsubsection{Objeto do direito de autor}

Como já mencionado, são objeto de tutela do direito de autor as obras estéticas, de conteúdo artístico, literário e científico, bem como os direitos que lhe são conexos. ${ }^{316}$ Assim, o direito de autor protege as criações do espírito materializadas em uma obra, também denominada criação. José Carlos Costa Netto ${ }^{317}$ sustenta que "a maioria dos juristas que se dedicaram ao estudo da matéria procurou deixar claro que o objeto da proteção não deve ser a ideia (que originou a obra), mas, sim, a sua concepção estética - a sua forma de expressão - materializada como 'obra intelectual'”. O referido autor cita, ainda, acórdão proferido em 11 de fevereiro de 1992 na Apelação Cível n. ${ }^{\circ}$ 946/1991, pela Quarta Câmara Cível do Tribunal de Justiça do Estado do Rio de Janeiro, cuja ementa dispõe: “[...] Assim, por mais original que possa ter sido a ideia e mesmo que tenha sido elemento decisivo na composição de determinada obra, somente esta (a obra concretizada) será objeto de proteção".

\footnotetext{
314 CHINELlATO, Silmara Juny de Abreu; HIRONAKA, Giselda Maria Fernandes Novaes. Propriedade e posse: uma releitura dos ancestrais institutos. Reflexos no direito autoral. Revista do Direito Autoral da ABDA, n. 1, p. 68, ago. 2004.

315 ASCENSÃO, José de Oliveira. Direito autoral. 2. ed. São Paulo: Renovar, 1997. p. 18.

316 COSTA NETTO, José Carlos. Direito autoral no Brasil. 2. ed. São Paulo: FTD, 1998. p. 71.

317 Idem, ibidem, p. 53-54.
} 
Para a proteção do direito de autor não se faz necessária a avaliação do valor da obra, seja seu valor financeiro ou sua inventividade, basta que ela seja fruto da criatividade de seu autor, ou seja, expressão de seu intelecto - e não mera reprodução -, e que seja original. Como a obra tutelada pelo direito de autor não possui caráter utilitário, não se faz necessário o preenchimento de outros requisitos, tal como instituído pela propriedade industrial. Ressalte-se, portanto, que a ideia não é objeto de proteção pelo direito de autor, pois, como dispõem a Constituição e a LDA, o pensamento deve ser livre e a criação partir das ideias e pensamentos compartilhados também, afinal, assim se promovem a evolução e o desenvolvimento, especialmente na atual sociedade da informação. ${ }^{318}$

Justamente por esse estímulo à difusão de ideias que contribuam para novas criações, o requisito da originalidade da obra de direito de autor deve ser analisado com cautela, pois não pode ser exigido ineditismo completo da obra, como condição para reconhecimento de sua originalidade, visto que os conhecimentos e as ideias são compartilhados e contribuem para a inspiração e o desenvolvimento intelectual de novas obras autorais. Assim, para que haja proteção ao direito de autor é essencial que a obra seja fruto da criatividade do autor, devendo ser original, expressada em um suporte material, com exceção dos casos em que a obra autoral se apresenta na cultura oral, ${ }^{319}$ dado que nesses casos a obra pode não possuir suporte material, ${ }^{320} \mathrm{e}$ ainda assim ser objeto de proteção.

Ainda, importante observar que são objeto do direito de autor tanto a obra originária, ou seja, aquela fruto da criatividade do autor, mas que não se inspirou em obra preexistente, como a obra derivada, desde que tenha contado com a autorização

318 O conceito de sociedade da informação indica o processo histórico, jurídico e econômico que ocorre a partir do momento em que a tecnologia proporciona avanços na produção, reduz a quantidade de empregos, levando ao deslocamento desses trabalhadores para o setor de prestadores de serviços, passando a desenvolver a classe dos trabalhadores intelectuais. E estes desenvolveram, em um curto espaço de tempo, setores da economia que exploram a informação e conhecimento, alterando o eixo em torno do qual a sociedade se organiza, passando a ser denominada de sociedade da informação (GRAU-KUNTZ, Karin. A interface da propriedade intelectual com o direito antitruste. Palestra proferida na Faculdade de Direito da Universidade de São Paulo em 22 de agosto de 2011. Disponível em: <http://www.ibpibrasil.org/40693/64901.html>. Acesso em: 10 nov. 2011).

BITTAR, Carlos Alberto. Direito de autor. 4. ed. atual. por Eduardo C.B. Bittar. São Paulo: Forense Universitária, 2008. p. 11-12. 
do autor da obra originária para que derivações fossem realizadas, e que seja independente da obra em que se inspirou. Isso porque, como o direito de autor não julga o valor das inovações intelectuais aportadas em determinada obra, qualquer adaptação ou continuidade à obra originária que surja da criatividade de outro autor deve ser tutelada pelo direito de autor e, por esse motivo, cumpridas as condições mencionadas, deve ser protegida como a original.

Analisando o conceito de patrimônio cultural imaterial, a grande questão que se coloca é: o patrimônio cultural imaterial é objeto do direito de autor? Não há dúvida de que a obra criada ou executada por membro de comunidade, a partir de seu patrimônio cultural imaterial, ${ }^{321}$ é objeto do direito autoral, por exemplo, uma pintura ou a execução de uma música ou dança. Contudo, o conhecimento ou as manifestações detidas por essa coletividade identificável, pertencente a essa comunidade, ainda que não incrustada em suporte material e sem que se possa precisar seus autores, são objeto do direito de autor? Essa é a questão que se pretende responder no capítulo seguinte.

\subsubsection{Direitos morais de autor}

Os direitos morais de autor correspondem a direitos pessoais, reconhecidos como direitos da personalidade, ${ }^{322}$ garantidos ao autor de determinada obra - ainda que esse autor não seja identificado. Para Clóvis Beviláqua os direitos morais de autor são manifestação da personalidade do autor e conferem o direito, a seu titular, de associar seu nome à obra que seu intelecto e criatividade produziram. Os direitos morais, por sua natureza, são inalienáveis, irrenunciáveis, conforme expressamente disposto pela LDA, em seu artigo 27 e são imprescritíveis, muito embora não haja afirmação expressa nesse sentido na legislação, considerando que a LDA não

\footnotetext{
321 Reitera-se que o presente trabalho não objetiva tratar da análise do patrimônio cultural imaterial detido pela coletividade e cuja titularidade já se tenha difundido a tal ponto que não é conhecida, por isso é analisado, apenas, se o patrimônio cultural imaterial detido por comunidade identificável pode - ou não - ser objeto do direito de autor.

322 BITTAR, Carlos Alberto. Direito de autor. 4. ed. atual. por Eduardo C.B. Bittar. São Paulo: Forense Universitária, 2008. p. 65; e CHINELLATO, Silmara Juny de Abreu. Direito de autor e direitos da personalidade: reflexões à luz do Código Civil. 2008. Tese (Concurso de Professor Titular de Direito Civil) - Faculdade de Direito da Universidade de São Paulo, São Paulo, p. 165.
} 
fixou termo para os direitos morais, mas apenas para o exercício dos direitos patrimoniais, conclui-se pela imprescritibilidade dos direitos morais de autor.

Os direitos morais de autor, embora não constem expressamente da Constituição Federal, devem ser entendidos como inerentes ao direito de autor e, portanto, se este é constitucionalmente protegido, também o é o direito moral de autor, uma vez que ele nasce com a obra. Na LDA os direitos morais de autor são detalhados em artigo específico, em rol não taxativo, posto que se trata de direito da personalidade, e justamente por esse motivo outros direitos morais de autor podem ser encontrados ao longo da norma, pulverizados em outros artigos, ${ }^{323}$ e até mesmo além da LDA ou de outros tratados internacionais. ${ }^{324}$

Feita essa importante ressalva, de que os direitos morais não se restringem àqueles relacionados no artigo $24^{325}$ da LDA, passar-se-ão apresentar os direitos garantidos por esse rol não taxativo. Primeiramente, há o direito de paternidade,

\footnotetext{
$\overline{323}$ É possível verificar a presença de direitos morais nos artigos 35 (direito de impedir que sucessores reproduzam versões anteriores da obra quando o autor tiver dado versão definitiva à obra), 66 (direito de alterar as edições seguintes), 70 (direito de opor-se a espetáculo mal ensaiado), entre outros.

CHINELlATO, Silmara Juny de Abreu. Direito de autor e direitos da personalidade: reflexões à luz do Código Civil. 2008. Tese (Concurso de Professor Titular de Direito Civil) - Faculdade de Direito da Universidade de São Paulo, São Paulo, p. 166.

"Art. 24. São direitos morais do autor:

I - o de reivindicar, a qualquer tempo, a autoria da obra;

II - o de ter seu nome, pseudônimo ou sinal convencional indicado ou anunciado, como sendo o do autor, na utilização de sua obra;

III - o de conservar a obra inédita;

IV - o de assegurar a integridade da obra, opondo-se a quaisquer modificações ou à prática de atos que, de qualquer forma, possam prejudicá-la ou atingi-lo, como autor, em sua reputação ou honra;

$\mathrm{V}$ - o de modificar a obra, antes ou depois de utilizada;

VI - o de retirar de circulação a obra ou de suspender qualquer forma de utilização já autorizada, quando a circulação ou utilização implicarem afronta à sua reputação e imagem;

VII - o de ter acesso a exemplar único e raro da obra, quando se encontre legitimamente em poder de outrem, para o fim de, por meio de processo fotográfico ou assemelhado, ou audiovisual, preservar sua memória, de forma que cause o menor inconveniente possível a seu detentor, que, em todo caso, será indenizado de qualquer dano ou prejuízo que lhe seja causado.
}

$\S 1 .^{\circ}$ Por morte do autor, transmitem-se a seus sucessores os direitos a que se referem os incisos I a IV.

$\S 2{ }^{\circ}$ Compete ao Estado a defesa da integridade e autoria da obra caída em domínio público.

$\S 3 .^{\circ}$ Nos casos dos incisos V e VI, ressalvam-se as prévias indenizações a terceiros, quando couberem." 
reconhecido pela Convenção de Berna $^{326}$ e pela LDA como o direito de reivindicar a autoria, isto é, a paternidade da obra, e ter seu nome nela indicado. ${ }^{327}$ Para muitos autores esse é considerado o direito moral de autor mais relevante, e Tullio Ascarelli, ${ }^{328}$ que reconhece o direito de autor como direito de propriedade, admite que os demais direitos morais poderiam resumir-se nesse único direito moral. Evidentemente, o direito de paternidade só pode ser exercido pelo autor da obra, contudo, em determinados casos, em função da transferência de titularidade sobre a obra, esse direito também pode ser exercido pelos sucessores do autor, enquanto vigente a proteção sobre a obra. Interessante observar que nos casos em que a obra é anônima e, portanto, a autoria é desconhecida, a LDA prevê que àquele que publicar a obra caberá o exercício dos direitos patrimoniais de autor, contudo não prevê a quem caberia o exercício dos direitos morais de autor, deixando subentendido que quem publica a obra anônima não pode pleitear o direito de paternidade e não possui direitos morais atrelados à obra. A violação a esse direito de paternidade - seja pela omissão ou pela indicação equivocada de autoria - gera, inclusive, efeitos patrimoniais, na medida em que os tribunais nacionais têm reconhecido que tal violação implica danos morais e materiais ao autor. ${ }^{329}$

Outro direito moral que deve ser analisado para os fins do presente trabalho é o direito de inédito, pois este decorre do direito à privacidade. Como ensina

\footnotetext{
326 O direito moral de paternidade sobre a obra é reconhecido no artigo 6 bis da Convenção de Berna: “1) Independentemente dos direitos patrimoniais de autor, e mesmo depois da cessão dos citados direitos, o autor conserva o direito de reivindicar a paternidade da obra e de se opor a toda deformação, mutilação ou a qualquer dano à mesma obra, prejudiciais à sua honra ou à sua reputação".

BRANCO, Sérgio. O domínio público no direito autoral brasileiro: uma obra em domínio público. Rio de Janeiro: Lumen Juris, 2011. p.187.

ASCARELLI, Tullio. Teoría de la concurrencia y de los bienes inmateriales. Traducción de E. Verderla y L. Suáres-Llanos. Studia albornotiana. Publicaciones del Real Colegio de España en Bolonia. Barcelona: Bosh, 1970. p. 695.

Conforme é possível verificar a partir do seguinte acórdão: "Responsabilidade civil. Contrato de prestação de serviços. Arte final em revista infantil. Direitos autorais. Ausência de menção ao nome do autor nos créditos. Ação de indenização por danos morais. Sentença de procedência parcial. Apelo de ambas as partes. Arte final considerada como auxílio na confecção da obra. Contribuição do autor na composição final das imagens. Direito ao reconhecimento do mérito profissional. Danos morais caracterizados. Ato ilícito configurado. Indenização devida. Valor arbitrado em quantia reduzida. Majoração Observância do disposto no artigo 944 do Código Civil. Honorários advocatícios. Pedido de redução Descabimento. Fixação de acordo com o disposto no artigo 20, 4. ${ }^{\circ}$, do Código de Processo Civil. Apelo dos réus desprovido, acolhido em parte o do autor" (TJSP,

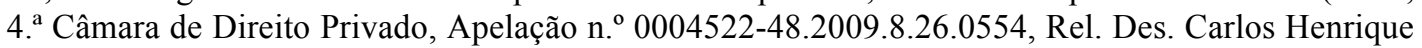
Miguel Trevisan, j. 26.06.2014).
} 
Silmara Juny de Abreu Chinellato, ${ }^{330}$ o direito de inédito surgiu a partir de discussões relacionadas ao direito da personalidade, em casos em que o direito à privacidade foi violado. A partir do reconhecimento do direito à privacidade, considerou-se que a reprodução não autorizada de imagem de determinada pessoa consistia em violação a tal direito e assim, a partir desse racional, nasceu o entendimento, para o direito de autor, de que a publicação não autorizada de obra - por mais que pudesse atender ao interesse público de ter aquela obra disponível - violava o direito à intimidade de seu autor, que deveria ter garantido o direito de optar por não publicar a obra em função de seu direito de inédito. De acordo com a LDA, o direito de inédito é garantido para o autor, que poderá, em prejuízo da sociedade, exercer o seu direito de não revelar a obra, sendo que tal direito é transmitido aos sucessores do autor, que podem, após o falecimento, realizar o lançamento da obra inédita se o autor já havia consentido com essa conduta.

Outra prerrogativa que integra os direitos morais de autor é o direito à integralidade da obra, que impede terceiros de realizar alterações na obra, que possam ferir a reputação ou honra do autor. Importante notar que nem mesmo aquele que detém o direito patrimonial sobre a obra, tampouco aquele que adquiriu o corpo mecânico no qual a obra está materializada, podem promover modificações na obra, direito este destinado exclusivamente ao titular do direito moral - o autor e, posteriormente, seus sucessores. Essa proteção garante que o nome do autor não seja associado a obra distorcida ou que não reflita sua criação de espírito. Modificações não autorizadas na reprodução da obra, como a transformação de obra audiovisual filmada em branco e preto para colorida ou a inclusão de música em filme ou a utilização da obra em outra mídia, são, portanto, proibidas, pois podem comprometer o senso estético da obra - no entendimento do autor - e impor ao autor sofrimento por ver sua reputação e honra associadas à obra alterada e que não concebeu daquela forma. Esse direito também se transmite aos sucessores do autor que devem defender a integralidade da obra. Em contrapartida ao direito negativo acima descrito - que impede aquele que não é o autor de alterar a obra sem autorização do mesmo -, há o direito positivo que garante ao autor a possibilidade de modificar a obra. Entretanto, esse direito é limitado, na medida em que o autor não pode exercê-lo se e quando tal exercício infringir direitos de terceiros,

330 CHINELlato, Silmara Juny de Abreu. Direito de autor e direitos da personalidade: reflexões à luz do Código Civil. 2008. Tese (Concurso de Professor Titular de Direito Civil) - Faculdade de Direito da Universidade de São Paulo, São Paulo, p. 173. 
como o direito do editor, garantido pelo artigo 66 da LDA, e não pode ser exercido pelos sucessores, dado que a modificação da obra somente pode ser realizada pelo autor ou por quem ele expressamente autorizar.

Por fim, interessa para os fins do presente trabalho a análise do direito de arrependimento e de retirada de circulação da obra já autorizada quando sua utilização afrontar a reputação e imagem do autor, que lhe são garantidos e reconhecidos como direito moral. O direito de arrependimento pode ser exercido quando a obra ainda não tenha sido publicada e haja vínculo contratual que o autor deseja rescindir. O exercício desse direito deve ser justificado, pois não possui como objetivo prejudicar o contratante de boa-fé e deve ser aplicado em regime de exceção para garantir que o autor expresse sua personalidade na obra. ${ }^{331}$ Já o direito de retirada de circulação pressupõe que a obra já tenha sido publicada e autorizada, reconhecendo o direito de suspender a utilização da obra pelo autor, porém somente quando tal uso implique afronta a sua reputação e imagem. Silmara Juny de Abreu Chinellato ensina que tal condição se mostra muito específica e pode levar à restrição do direito conferido ao autor de suspender o uso de sua obra em situações que afrontam seu direito da personalidade, mas que não causam danos à reputação e concomitantemente à imagem aqui entendida como atributos morais, e não em seu sentido literal -, por exemplo nos casos em que o autor mudou de opinião ou quando considera a obra desatualizada. De toda forma, o exercício do direito de arrependimento ou de retirada de circulação deve ser objeto de indenização à contraparte, em função da responsabilidade civil por danos a esta ou a terceiros, sempre que o arrependimento ou retirada decorram de motivação unilateral do autor. Contudo, caso o fundamento para o exercício desses direitos seja a conduta da contraparte, que pode ofender a reputação e a imagem do autor, cabe, ao revés, indenização para este, suportada pela contraparte.

Diante dos direitos morais de autor anteriormente apresentados, verifica-se que tais dispositivos buscam proteger o autor, identificável, bem como a obra. Em função desse entendimento, poder-se-ia pensar que tais direitos morais não seriam aplicáveis às criações cujos autores não se podem identificar, como ocorre com a

331 CHINEllato, Silmara Juny de Abreu. Direito de autor e direitos da personalidade: reflexões à luz do Código Civil. 2008. Tese (Concurso de Professor Titular de Direito Civil) - Faculdade de Direito da Universidade de São Paulo, São Paulo, p. 192. 
criação de manifestações culturais imateriais. No entanto, dado que as disposições constitucionais são claras no sentido de garantir a proteção às manifestações culturais dos povos e comunidades tradicionais, e que tais criações são fruto do intelecto humano daquela coletividade e, portanto, ainda que individualmente, todos daquele grupo possuem direitos da personalidade a serem tutelados, verifica-se que os dispositivos normativos vigentes devem ser interpretados em conformidade com a Constituição Federal para fins de viabilizar a referida proteção ao patrimônio cultural imaterial detido por comunidade determinável. ${ }^{332}$ Partindo-se dessa premissa, será possível verificar, adiante, se cabe, na proteção ao PCI, a garantia dos direitos morais supradescritos.

\subsubsection{Titularidade do direito de autor}

Identificados o conceito, a natureza jurídica e o objeto do direito de autor, necessária a avaliação dos titulares desse direito, especialmente dos direitos morais, que são os que mais interessam à presente dissertação. Em razão da natureza e finalidade do direito de autor, verifica-se que este surge com a criação, portanto a titularidade do direito cabe ao autor da obra. Em determinadas circunstâncias, a titularidade de direitos de autor pode, excepcionalmente, derivar de atos não relacionados à criação, tais como o direito adquirido em função de sucessão ou decorrente de obrigação contratual. Nessas hipóteses, ainda que haja transferência a terceiro da titularidade, os direitos transferidos sofrem algumas limitações, dado que determinados direitos morais são intransferíveis e se extinguem com a morte do autor, como o direito de modificar a obra, de retirá-la de circulação e de ter acesso a exemplar de obra rara. ${ }^{333}$

Necessário, ainda, identificar quem pode ser autor e, portanto, titular dos referidos direitos patrimoniais e morais, decorrentes da obra. A LDA define "autor" como "a pessoa física criadora de obra literária, artística ou científica". ${ }^{334}$ Referindo-se ao autor enquanto pessoa física, afirma José Carlos Costa Netto que "o titular originário

\footnotetext{
332 DRUMMOND, Victor Gameiro. A tutela jurídica das expressões culturais tradicionais. 2001. Tese (Mestrado) - Universidade de Lisboa, Faculdade de Direito, Lisboa, p. 212. No prelo.

333 BRANCO, Sérgio. O domínio público no direito autoral brasileiro: uma obra em domínio público. Rio de Janeiro: Lumen Juris, 2011. p. 186.

334 Brasil. Lei de Direitos Autorais. Artigo 11.
} 
de direito de autor não pode ser outro senão o criador da obra intelectual, ou seja, o autor, "pessoa física", ${ }^{335}$ Já Carlos Alberto Bittar sustenta que titular é a pessoa que cria, idealiza e materializa a obra, podendo ser pessoa física, de qualquer idade ou capacidade, e inclusive os incapazes podem ser autores, devidamente representados nos termos da lei civil.

Nesse contexto, importante indicar o conceito de titularidade original e derivada ${ }^{336}$ para tornar a análise da titularidade do Direito de Autor mais precisa. Carlos Alberto Bittar ${ }^{337}$ considera que o titular originário da obra é o seu criador, sustentando que na obra coletiva a pessoa jurídica pode ser titular de direitos em razão do trabalho de direção ou coordenação que realiza. A titularidade originária caracteriza-se, portanto, quando o titular dos direitos de autor é também o autor da obra. Por sua vez, a titularidade derivada se dá nas situações em que o titular dos direitos não coincide com o autor da obra. Assim, eventual herdeiro que passa a deter o exercício dos direitos patrimoniais sobre a obra, bem como determinados direitos morais, é titular de direitos de autor, porém possui titularidade derivada, pois não é o criador da obra. Da mesma forma, aquele que adquire os direitos sobre determinada obra em razão de contrato de cessão passa a deter a titularidade derivada sobre ela, e, por fim, nos casos de obras anônimas ou pseudônimas, há titularidade de direitos autorais derivada e não originária.

Feita essa distinção, para Antonio Carlos $\operatorname{Morato}^{338}$ a pessoa jurídica também pode ser titular originária de direitos autorais, dado que é autora, idealizadora e encomendante de obra coletiva a ser implementada por pessoas físicas que seguem suas diretrizes e orientações, sendo, portanto, passível de titularidade originária de direitos morais e patrimoniais em obras coletivas. Nesse mesmo sentido, Silmara Juny de Abreu Chinellato $^{339}$ admite que a pessoa jurídica pode ser autora de obra coletiva e considera que o artigo 52 do Código Civil, ao determinar que se aplica à pessoa jurídica a

\footnotetext{
COSTA NETTO, José Carlos. Direito autoral no Brasil. 2. ed. São Paulo: FTD, 1998. p. 60.

336 AFONSO, Otávio. Direito autoral: conceitos essenciais. Barueri: Manole, 2009. p. 33-34.

337 BITTAR, Carlos Alberto. Contornos atuais do direito do autor. São Paulo: RT, 1992. p. 21.

338 MORATO, Antonio Carlos. Direitos de autor em obra coletiva. 2.ed. São Paulo: Saraiva, 2007. p. 48. No prelo.

339 CHINELLATO, Silmara Juny de Abreu. Direito de autor e direitos da personalidade: reflexões à luz do Código Civil. 2008. Tese (Concurso de Professor Titular de Direito Civil) - Faculdade de Direito da Universidade de São Paulo, São Paulo, p. 205-210.
} 
proteção dos direitos da personalidade, no que couber, ampara o entendimento de que pode ser atribuída autoria à pessoa jurídica.

Ressalte-se que, muito embora esse não seja o posicionamento majoritário na doutrina, ${ }^{340}$ os argumentos sustentados por Antonio Carlos Morato, Silmara Juny Chinellato e Carlos Alberto Bittar indicam, com solidez, a viabilidade do reconhecimento de autoria originária pela pessoa jurídica que ocupa, por vezes, o papel de encomendante idealizador da obra. Assim, tal qual o entendimento no caso de obra por encomenda, em que se reconhece a titularidade originária dos direitos de autor ao encomendante, se a obra desenvolvida sob idealização, gestão e direcionamento da pessoa jurídica preencher os requisitos ${ }^{341}$ para ser reconhecida como criação tutelada de direito de autor, a pessoa jurídica poderá ser a autora originária.

Sustenta, ainda, Antonio Carlos Morato que a pessoa jurídica é titular de direitos da personalidade, como o direito à honra objetiva, e que seria um contrassenso reconhecer a titularidade dessa modalidade de direitos às pessoas jurídicas, mas não os direitos morais de autor. Partindo-se desse entendimento, Antonio Carlos Morato afirma que a autoria pode se desdobrar em objetiva e subjetiva. ${ }^{342}$ A autoria subjetiva seria detida pelas pessoas físicas, que promovem o "ato físico de criação" e que integram a pessoa jurídica e implementam as ações necessárias à elaboração da obra, orientadas pela pessoa jurídica e sob sua coordenação. Já a autoria objetiva seria a prevista pelo artigo 11 da LDA, parágrafo único, garantida à pessoa jurídica com direito moral de paternidade sobre a obra coletiva e que é reconhecida como titular originária da obra. ${ }^{343}$

\footnotetext{
340 José Carlos da Costa Netto sustenta que apenas a pessoa física pode criar e, portanto, apenas ela pode ser titular originária de obra de direito de autor. Em sentido análogo posicionam-se Hildebrando Pontes e Guilherme Carboni, reconhecendo a criação como faculdade exclusiva da pessoa física (CARBONI, Guilherme. $O$ direito de autor na obra multimídia. São Paulo: Quartier Latin, 2003. p. 179; PONTES, Hildebrando. Autoria e obra coletiva. In: PIMENTA, Eduardo Salles. Direitos autorais: estudos em homenagem a Otávio Afonso dos Santos. São Paulo: RT, 2007. p. 133-147; COSTA NETTO, José Carlos. Direito autoral no Brasil. 2. ed. São Paulo: FTD, 1998. p. 54). Os requisitos de originalidade e criatividade.

342 MORATO, Antonio Carlos. Direitos de autor em obra coletiva. 2. ed. São Paulo: Saraiva, 2007. p. 69. No prelo. 
Identificado esse desdobramento da autoria, se for possível verificar determinada manifestação cultural como de origem de determinado povo ou comunidade tradicional, considerando que a legislação dispõe que devem ser respeitados os modos tradicionais de organização dessa comunidade, ${ }^{344}$ pode-se sustentar que tais comunidades, organizadas de maneira tradicional, possuindo líderes e representações tradicionais - ainda que não sigam estrutura jurídica convencional -, poderiam ser equiparadas a pessoas jurídicas e, portanto, lhes seria aplicável a proteção dos direitos da personalidade, tal como sustenta o artigo 52 do Código Civil. Em função disso, assumindo que as comunidades ou povos tradicionais podem ser compreendidos como pessoa jurídica, ${ }^{345}$ podem ser equiparadas a titulares originários de suas manifestações, possuindo direitos morais, representando a coletividade de autores, inclusive intergeracionais, existentes na comunidade e que atuam de modo a expressar a identidade dessa comunidade ou povo tradicional, tal como a pessoa jurídica o é no caso de obra coletiva que idealiza. Note-se, ainda, que boa parte das comunidades e povos tradicionais hoje já se organiza de forma a constituir pessoa jurídica que os represente, portanto, em alguns casos, as comunidades sequer precisariam ser equiparadas a pessoas jurídicas, posto que o são de direito.

A corroborar esse entendimento, Victor Drummond não apenas reconhece em sua dissertação que as comunidades e povos tradicionais identificáveis e vivos podem possuir titularidade originária sobre as manifestações culturais que são criadas e surgem em seu contexto tradicional, como detalha que o Estado possui a titularidade derivada, assim como titulares de direitos difusos, nas hipóteses em que a manifestação cultural seja criada por comunidade ou povo tradicional não identificável ou extinto. ${ }^{346}$

\footnotetext{
344 Cf. SANTILLI, Juliana. Conhecimentos tradicionais associados à biodiversidade: elementos para a construção de um regime jurídico sui generis de proteção. In: VARELLA, Marcelo Dias; PLATIAU, Ana Flávia Barros (Org.). Diversidade biológica e conhecimentos tradicionais. Belo Horizonte: Del Rey, 2004. p. 361: "A legitimidade para representar um povo indígena quilombola ou população tradicional, em uma autorização de acesso, só pode ser estabelecida a partir das normas e critérios internos desses povos".

345 DALLARI, Dalmo de Abreu. Índios, cidadania e direitos. $O$ índio e a cidadania. São Paulo: Brasiliense, 1983. p. 19.

DRUMMOND, Victor Gameiro. A tutela jurídica das expressões culturais tradicionais. 2001. Tese (Mestrado) - Universidade de Lisboa, Faculdade de Direito, Lisboa, p. 11. No prelo.
} 
A partir desse entendimento, conclui-se que, sendo a comunidade ou povo tradicional vivo e identificável, este equipara-se a pessoa jurídica e pode ser reconhecido como titular originário - e, portanto, titular de direitos morais - sobre obras coletivas criadas por seus membros. Se a comunidade ou povo tradicional é identificado, mas não existe até os dias atuais, ou seja, não está viva, ainda que identificável, a titularidade sobre as manifestações culturais que possuía passa a ser do Estado, caracterizando sua titularidade derivada. Igualmente, se determinada manifestação cultural não é relacionada a comunidade ou povo tradicional identificável, a titularidade dela é do Estado, como titular derivado, e que deverá zelar para que ela não seja objeto de apropriação indevida por terceiros e possa ser conservada e divulgada, atendendo-se aos interesses coletivos da sociedade de acesso à cultura, o feixe de direitos de interesse público.

A partir desse raciocínio, conclui-se que na tutela do patrimônio cultural imaterial existem e devem ser reconhecidos os direitos como titular originário da comunidade ou povo tradicional vivo e identificável que cria manifestação cultural, existindo, portanto, direitos morais a essas manifestações culturais por parte da comunidade ou povo tradicional. Diante dessa conclusão, surge o questionamento sobre se os demais direitos previstos sob a tutela do Direito de Autor também seriam aplicáveis ao patrimônio cultural imaterial, em especial se a forma de criação do patrimônio cultural imaterial poderia se enquadrar no conceito de obras coletivas do direito de autor. Para que essa análise possa ser realizada, será observado como se comporta a titularidade dos direitos de autor nas situações em que existe mais de um criador, a fim de identificar se uma dessas modalidades de coautoria - especialmente a obra coletiva - poderia acomodar o tratamento ao patrimônio cultural imaterial, além da tutela do direito moral conferido à comunidade ou povo tradicional identificável e vivo, titular originário de manifestações culturais. As obras desenvolvidas por mais de um autor são denominadas plúrimas ${ }^{347}$ e possuem diversas modalidades, as quais serão investigadas adiante.

347 BITTAR, Carlos Alberto. Contornos atuais do direito do autor. São Paulo: RT, 1992. p. 36. 


\subsection{Modalidades de obras plúrimas}

Muito embora se observe que a regulamentação à propriedade intelectual, assim como, especificamente, ao direito autoral, tratam das relações de criação individual ou ao menos de coletividade identificável, serão avaliadas as modalidades de obras de autoria plúrima existentes em nossa legislação, a fim de permitir a respostas às três questões antes apresentadas e identificar se há possibilidade de enquadramento do patrimônio cultural imaterial em algum desses conceitos, seja para defini-lo como criação em domínio público ou como obra de autoria plúrima, sujeita à proteção no escopo do direito de autor.

Integram o conceito de obra de autoria plúrima as obras cuja execução demandam a participação de dois ou mais autores. Assim, como dispõe a LDA e como previu a norma anteriormente vigente, Lei n. ${ }^{\circ} 5.988$, de 14 de dezembro de $1973,{ }^{348}$ as obras que podem ser compreendidas como de autoria plúrima são: as obras coletivas, as em coautoria, as colaborativas e a compósita, as quais serão detalhadas a seguir.

\subsubsection{Obra coletiva}

De acordo com José de Oliveira Ascensão, ${ }^{349}$ a obra coletiva é aquela elaborada por um grupo identificável de autores e que depende do trabalho de um organizador para ser preparada. As funções de organizador da obra coletiva podem ser exercidas tanto por pessoa física quanto jurídica, de acordo com Antonio Carlos Morato $^{350}$ e Carlos Alberto Bittar. ${ }^{351}$ Por esse motivo, todos os direitos relacionados a ela pertencem exclusivamente ao organizador, sendo reconhecido o direito aos autores individuais por suas participações.

348 BRASIL. Lei n. ${ }^{\circ} 5.988$, de 14 de dezembro de 1973 . Disponível em $<$ http://www.planalto.gov.br/ccivil_03/leis/15988.htm>. Acesso em: 5 abr. 2014.

350 MORATO, Antônio Carlos. Direitos de autor em obra coletiva. 2. ed. São Paulo: Saraiva, 2007. p. 60-69. No prelo.

351 BITTAR, Carlos Alberto. Contornos atuais do direito do autor. São Paulo: RT, 1992. p. 43-44. 
A obra coletiva é, portanto, criada por iniciativa, organização e responsabilidade de uma pessoa física ou jurídica, que a publica sob seu nome ou marca, e constituída pela participação de diferentes autores, cujas contribuições se fundem em uma criação autônoma. ${ }^{352}$ Tal obra é uma unidade, ${ }^{353}$ sendo, portanto, indivisível. Para Antonio Carlos Morato ${ }^{354}$ ocorre a fusão de todas as colaborações em uma obra final, havendo uma pessoa que a projeta e coordena, sendo o resultado final autônomo, ainda que seja preservada a proteção das participações individuais. Assim, é modalidade de obra que se caracteriza pela incindibilidade, ${ }^{355}$ em função de todas as obras individuais terem sido inseridas na obra coletiva a partir do projeto idealizado pelo organizador, com o objetivo de constituir a obra em si.

Portanto, haveria a indivisibilidade permanente da obra, que implicaria um conjunto de obra distinto das partes individuais que a compõem. ${ }^{356}$ Inclusive, há entendimento consolidado na jurisprudência ${ }^{357}$ no sentido de reconhecer a incindibilidade das criações individuais, com o intuito de proteger a expressão criativa do organizador da obra coletiva. Entretanto, a jurisprudência ${ }^{358}$ também reconhece que,

LDA, artigo 5. ${ }^{\circ}$, VIII, $h$.

ASCENSÃO, José de Oliveira. Direito autoral. 2. ed. São Paulo: Renovar, 1997. p. 127.

354 MORATO, Antônio Carlos. Direitos de autor em obra coletiva. 2.ed. São Paulo: Saraiva, 2007. p. 45. No prelo.

355 BITTAR, Carlos Alberto. Contornos atuais do direito do autor. São Paulo: RT, 1992. p. 43-44.

356 MORATO, Antônio Carlos. Direitos de autor em obra coletiva. 2.ed. São Paulo: Saraiva, 2007. p. 4. No prelo.

357 Ressalta Bittar que, desde o caso da Enciclopédia Francesa, construiu-se o entendimento de que a obra coletiva é incindível e que o direito moral do autor individual somente poderá ser exercido se não prejudicar a obra coletiva.

358 Responsabilidade civil. Direito autoral. Autora que ministrou, por longo tempo, aulas da disciplina "História" para alunos do ensino médio e de cursos pré-vestibulares das rés. Elaboração, nesse período, juntamente com outros professores, de material didático de referida disciplina. Comercialização pelas rés verificada, mesmo após a interrupção do contrato de trabalho. Alegação de pagamento de valor ínfimo e de nulidade do contrato celebrado pelas partes, por ter sido coagida a firmá-lo. Ilegitimidade ativa e passiva. Tema que se confunde com o mérito da causa. Celebração de contrato pelas partes que restou nebulosa. Existência de argumentos contraditórios de ambas as partes. Inexistência de contrato a ser considerado nulo. Material didático em questão que se trata de obra coletiva. Autoria que cabe à pessoa física ou jurídica organizadora, inocorrência de violação ao direito autoral da autora. Ausência de demonstração de qualquer prejuízo. Indenização indevida. Ação improcedente. Ônus da sucumbência a cargo da autora, respeitada a gratuidade. Recurso das rés provido, prejudicado o recurso da autora" (TJSP, $1 .{ }^{a}$ Câmara de Direito Privado, Apelação Cível n. ${ }^{\circ}$ 9279275-80.2008.8.26.0000/São Paulo, Rel. Des. Luiz Antonio de Godoy, v.u.). E ainda: "Bíblia Sagrada - Edição Pastoral", obra lançada em 1990. Aplicação à espécie dos autos da Lei n. ${ }^{\circ} 5.988$, de 1973. Obra coletiva. Reconhecimento. Apelada que organizou a obra, com a participação de diversas pessoas ao lado dos apelantes. Direitos autorais que tocam à recorrida. Aplicação do disposto no artigo 15 da Lei n. ${ }^{\circ}$ 5.988, 1973. Prescrição. Discussão inócua. Direitos morais e 
uma vez sendo as obras individuais independentes da obra coletiva, ou seja, passíveis de serem excluídas da obra ou de serem utilizadas pelo autor individual em outras obras, sem trazer prejuízo à obra coletiva, poderá o autor da obra individual exercer seus direitos patrimoniais e morais sem limitações.

São exemplos de obras coletivas as obras cinematográficas, os jornais, as publicações periódicas, as enciclopédias e os dicionários, ${ }^{359}$ cabendo aos organizadores de tais obras os direitos de autor delas decorrentes, sempre que houver a coordenação do trabalho. Contudo, importante analisar as limitações aos direitos de autor que aqueles autores das obras individuais experimentam para a tutela da obra coletiva, a fim de avaliar se tais limitações se assemelham àquelas geradas pela tutela e proteção do patrimônio cultural imaterial. Cabe ao autor individual participação nos direitos patrimoniais na forma acordada entre ele e o organizador. No entanto, quanto aos direitos morais, é facultado ao autor individual requerer a exclusão de seu nome na obra, desde que notifique o organizador, por escrito, até a entrega de sua participação. Caso a obra seja publicada e, posteriormente, o autor individual deseje a exclusão de sua parte na obra coletiva, sem causar, com isso, prejuízos à obra coletiva, não poderá ser excluída, constituindo, portanto, limitação aos direitos morais do autor individual.

Em respeito ao direito moral de paternidade sobre a obra, o autor individual deve ser reconhecido como tal, tendo a indicação de seu nome na obra. Ainda, ao autor individual, cuja contribuição possa ser utilizada separadamente, são asseguradas todas as faculdades inerentes à sua criação como obra individual, vedada, porém, a utilização que possa acarretar prejuízo à exploração da obra comum. ${ }^{360}$ Tais limitações aos direitos morais dos autores das participações individuais se explicam por ser a obra coletiva uma obra indivisível que pode impor restrições de utilização da participação individual sempre que necessário para proteção da obra coletiva, idealizada pelo organizador.

patrimoniais que tocam exclusivamente à recorrida (artigo 21 da referida lei). Procedência parcial da declaratória e improcedência da indenizatória preservada. Apelo improvido" (TJSP, 3. a Câmara de

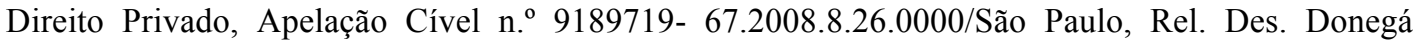
Morandini, j. 28.01.2010, v.u.).

359 MORATO, Antônio Carlos. Direitos de autor em obra coletiva. 2. ed. São Paulo: Saraiva, 2007. p. 153. No prelo.

360 BITTAR, Carlos Alberto. Contornos atuais do direito do autor. São Paulo: RT, 1992. p. 36-38. 
A partir dessa análise, verifica-se que a modalidade de obra coletiva não reflete de maneira precisa o sistema de criação do patrimônio cultural imaterial de povos e comunidades tradicionais, especialmente por três razões. A primeira delas é o fato de não ser possível identificar todos os autores que contribuíram para a criação da manifestação cultural no âmbito da comunidade tradicional. A segunda razão é o fato de, em tese, não haver organizador ou idealizador da manifestação cultural, sendo esta criada a partir da contribuição individual de seus membros - estas participações individuais claramente protegidas pelos direitos autorais -, sejam estes vivos ou de gerações passadas. E a terceira é o prazo de proteção conferido às obras coletivas. Embora a proteção garantida aos direitos morais não sofra limitação temporal - embora determinados direitos morais possam ser limitados com a integração da manifestação ao domínio público, por exemplo, o direito de autorizar ou não o uso da manifestação cultural -, os direitos patrimoniais, no caso de obra coletiva detida por pessoa jurídica, vigem por tempo limitado. Embora a LDA não fixe esse prazo de forma expressa, pode ser aplicado, por analogia, o prazo de proteção conferido à obra cinematográfica, cujos direitos patrimoniais recaem sobre o diretor, situação análoga à obra coletiva organizada por pessoa jurídica, sendo assim protegido pelo prazo de 70 anos a contar de $1 .^{\circ}$ de janeiro do ano subsequente ao da primeira exibição da manifestação cultural. Ora, basta considerar o conceito de patrimônio cultural imaterial, sua natureza jurídica e seu processo de criação para concluir que seria muito complexa - se não impossível - a aplicação desse prazo a manifestações culturais, dado que: o que constituiria a primeira exibição de uma manifestação cultural? E ainda, considerando que o patrimônio cultural imaterial caracteriza-se por ser criado a partir de processo longo, lento e intergeracional, certamente as manifestações culturais de povos e comunidades tradicionais já teriam mais de 70 anos e, portanto, não gozariam dessa proteção.

Por outro lado, exercitando a possibilidade de interpretação e compreensão desses conceitos de obra coletiva, se consideramos a comunidade tradicional como pessoa jurídica, é possível, em analogia ao papel da pessoa jurídica autora em obra coletiva, presumir que a comunidade ou povo tradicional exerce também o papel de titular originário dos direitos sobre as manifestações culturais criadas no âmbito da comunidade, em função de esta ter criado os meios necessários para esse processo coletivo e intergeracional de criação, podendo ser equiparada ao organizador da obra. No que concerne ao prazo de proteção da manifestação cultural, reitera-se que 
no tocante aos direitos morais não há qualquer impedimento para seu reconhecimento, dado que esses direitos não estão sujeitos à limitação temporal. No entanto, quanto aos direitos patrimoniais, considerando que não há previsão expressa definindo esse prazo para essa situação específica, poder-se-ia sustentar que, no caso de obras coletivas integrantes do patrimônio cultural imaterial de comunidades e povos tradicionais vivos e identificáveis, o prazo de 70 anos de proteção passaria a contar da "morte" de seu titular, ou seja, a partir da extinção da comunidade tradicional - o que pode ocorrer. Assim, o prazo de 70 anos seria iniciado somente se e quando a comunidade tradicional identificável deixasse de ser viva.

No entanto, ainda que se superem esses dois desafios para enquadramento do processo de criação do patrimônio cultural imaterial no conceito de obra coletiva, verifica-se não há como superar o fato de que não é possível identificar todos os autores que contribuíram para o desenvolvimento dessas manifestações culturais. A consequência disso é o fato de não ser possível identificar o momento da criação e como consequência não poderem ser garantidos os direitos às participações individuais a todos aqueles que contribuíram para a criação. Ora, se o direito de autor surge da relação entre autor e obra, a partir de sua criação, se não é possível identificar o autor, tampouco o momento de criação, não é possível sustentar que há relação tutelada pelo direito de autor nesse caso. Assim, mesmo com todo o esforço interpretativo realizado, verifica-se que a modalidade de obra coletiva não permite incluir em sua conceituação as manifestações culturais integrantes do patrimônio cultural imaterial de comunidades e povos identificáveis.

Desse modo, ainda que a comunidade possa ser identificada como titular e criadora de determinada manifestação cultural, tal como uma música, uma dança, um grafismo corporal, essa criação não se enquadra no conceito de obra coletiva tutelada pelo direito de autor. Entretanto, no tocante aos direitos morais, dado que estes são garantidos até mesmo no caso de autoria desconhecida e que o fato de não estarem sujeitos à limitação temporal se coaduna com as características do processo criativo das manifestações culturais de povos e comunidades tradicionais, pode-se concluir que estas podem ser consideradas titulares originárias de direitos morais sobre manifestações culturais criadas em seu âmbito, ainda que não possam ser reconhecidos todos os autores individuais, como forma de garantir à proteção ao direito fundamental à cultura 
dessas comunidades, bem como o direito da personalidade da coletividade e daqueles indivíduos que a compõem.

\subsubsection{Obra em coautoria}

A obra em coautoria, como define o artigo $5^{\circ}$, VII, $a$, da LDA, é aquela criada em comum, por dois ou mais autores. A Lei n. ${ }^{0} 5.988$ de $1973,{ }^{361}$ revogada pela LDA, não tratava da coautoria, mas sim da obra colaborativa, podendo ser compreendida como decorrência da c-autoria, ou seja, como a obra produzida em comum, por dois ou mais autores.

Antônio Chaves destaca a dificuldade de se distinguirem os conceitos de coautoria e obra em colaboração, pois ambos tratam da elaboração de obra intelectual por duas ou mais pessoas. Contudo, ensina que, na obra em coautoria, as participações e contribuições dos autores ocorrem em proporções semelhantes, enquanto as participações nas obras colaborativas são consideradas uma cota, em relação ao todo da obra. ${ }^{362}$ Para Vieira Manso, na coautoria há a contribuição de um autor para o outro, trabalhando em conjunto ou executando suas partes em separado, sendo característica dessa modalidade de obra a indivisibilidade, que pode ser relativa, quando for possível valorar separadamente cada uma das partes que compõem a obra. ${ }^{363}$

Antonio Carlos Morato ${ }^{364}$ afirma que pode haver a independência ou a fusão de contribuições individuais para resultar em uma obra em coautoria, em que, diferentemente da obra colaborativa, não há um organizador ou coordenador, mas sim criação conjunta por meio das contribuições individuais. Para Ascensão, "é uma obra que, no seu conjunto, resulta da criação comum de vários autores", e pode ser indivisível.

\footnotetext{
Disponível em: <http://www.planalto.gov.br/ccivil_03/leis/L5988.htm>. Acesso em: 9 jun. 2012.

CHAVES, Antônio. Direitos de autor: princípios fundamentais. Rio de Janeiro: Forense, 1987. p. 97-98.

363 MANSO, Eduardo Vieira. Direito autoral. São Paulo: Bushatsky, 1980.

364 MORATO, Antônio Carlos. Direitos de autor em obra coletiva. 2. ed. São Paulo: Saraiva, 2007. p. 6-9. No prelo.

365 ASCENSÃO, José de Oliveira. Direito autoral. 2. ed. São Paulo: Renovar, 1997. p. 98.
} 
De acordo com Carlos Alberto Bittar, ${ }^{366}$ a obra em coautoria é aquela produzida pela comunhão de esforços comuns, por dois ou mais autores, podendo ocorrer distintos graus de coautoria, a depender da contribuição criativa comum, para desenvolvimento da obra ou da contribuição individual dos trabalhos independentes de cada coautor. Assim, para esse autor, a obra em coautoria pode possuir divisibilidade absoluta, nas hipóteses em que as obras utilizadas na criação sejam obras autônomas, que, após serem conjugadas, conservam sua individualidade, por exemplo, em coletâneas de artigos. Pode, ainda, a obra em coautoria possuir divisibilidade relativa, nas situações em que, embora as contribuições individuais sejam autônomas, uma vez congregadas acabam por integrar-se, de forma que passam a ser necessárias para a configuração da obra colaborativa, como na situação da composição de letra e música por autores distintos. Por fim, a obra em coautoria pode ser indivisível, sendo uma fusão das contribuições pessoais, ${ }^{367}$ de tal modo que o resultado final da obra é decorrente da criação conjunta e comum na redação ou criação da obra, por exemplo, na escrita em comum de livros, artigos ou na composição em parceria de músicas.

Nas obras em coautoria algumas dificuldades para determinação e exercícios dos direitos de autor são identificadas. Por exemplo, a identificação da autoria da obra colaborativa é tema que pode gerar discussão, afinal, normalmente a autoria cabe ao criador. No caso das obras em coautoria, necessariamente existirá mais de um autor e, por esse motivo, a autoria deve ser reconhecida a todos os que contribuíram entre si para seu desenvolvimento. ${ }^{368}$ Por esse motivo, outra dificuldade surge para a exploração das obras em coautoria, afinal, se todos os coautores possuem direitos, devem ser obtidas autorizações de todos para a utilização da obra. Assim, constata-se que os direitos sobre tais obras devem ser regidos sob as regras do condomínio comum, pois há comunhão de direitos sobre a obra, partilhados entre os coautores.

Isso significa que caberá aos coautores disciplinarem de comum acordo a forma de gestão da obra e as condições para sua exploração. Entretanto, podem

\footnotetext{
BITTAR, Carlos Alberto. Contornos atuais do direito do autor. São Paulo: RT, 1992. p. 36-38. 
ocorrer situações em que os coautores tenham de enfrentar limitações a seus direitos, especialmente tratando-se de obra indivisível. Assim, sendo a obra uma fusão das contribuições individuais, cada coautor deterá em condomínio uma fração ideal da obra comum. Tal situação poderá acarretar conflitos nas situações em que não haja consenso entre os coautores na utilização da obra. Imagine-se, por exemplo, se um coautor não deseja publicar a obra e os demais, sim. Nessa hipótese, faz-se necessária a decisão pela maioria dos coautores e, caso se decida pela publicação, é facultado ao coautor discordante que não arque com os custos de publicação, renunciando à sua parte nos lucros, e que proíba a inclusão de seu nome na obra. Caso a obra em coautoria seja cindível, cada coautor poderá explorar sua obra individualmente, desde que tal uso não implique qualquer prejuízo à obra comum.

Pelas características da obra em coautoria, o patrimônio cultural imaterial poderia ser enquadrado nessa modalidade de obra plúrima, uma vez que para seu desenvolvimento os diversos membros de uma determinada coletividade contribuem para sua criação. Inclusive, o conflito de direitos e interesses entre os coautores pode ser identificado entre os membros de determinada comunidade criadora de manifestação cultural, dado que um membro pode considerar razoável autorizar a exploração de determinada manifestação cultural por empresa e outros integrantes da comunidade não concordarem, devendo prevalecer as formas tradicionais de organização dessa comunidade na decisão sobre a exploração ou não dessa manifestação e na sua falta as regras aplicáveis a condomínio.

Todavia, muito embora o processo de desenvolvimento de uma manifestação cultural exija a atuação de diversos coautores, observa-se que para a sua criação não contribuem apenas as pessoas integrantes, naquele momento, da comunidade, mas também seus antepassados, pois normalmente as manifestações culturais são transmitidas de geração a geração e, portanto, têm sua autoria atrelada à coletividade, ao grupo e não a pessoas identificáveis, até porque as manifestações podem ser recriadas a todo momento. ${ }^{369}$

369 DRUMMOND, Victor Gameiro. A tutela jurídica das expressões culturais tradicionais. 2001. Tese (Mestrado) - Universidade de Lisboa, Faculdade de Direito, Lisboa, p. 32-42. No prelo. 
Por esse motivo, ainda que o patrimônio cultural imaterial de comunidades tradicionais identificáveis possa envolver diversos coautores para sua criação, as manifestações culturais não se enquadram perfeitamente no conceito de obra em coautoria, uma vez que parte dos coautores não é identificável, além de serem aplicáveis as mesmas reflexões quanto ao prazo de proteção dessas obras no direito de auto, apresentadas no item anterior, referente a obras coletivas. Por outro lado, observase que a obra em coautoria é a que mais se assemelha ao processo de criação do patrimônio cultural imaterial, resultando em criações incindíveis e, portanto, seu estudo, em especial a análise das limitações de direitos que um coautor impõe ao outro, pode ser utilizado em analogia para auxiliar no entendimento dos conflitos que podem surgir relacionados ao patrimônio cultural imaterial.

\subsubsection{Obra compósita}

A obra compósita é aquela conhecida por derivada, ou seja, que incorpora obra preexistente, sem a participação do autor originário, criando e inserindo originalidade à obra inicial, mas que para ser desenvolvida deve contar com autorização do autor da obra original. O autor da obra compósita é seu legítimo titular, desde que respeite as condições acima, sendo certo que os direitos sobre a obra original permanecerão com o autor primigênio, respeitados os limites da autorização concedida para a elaboração da obra derivada.

$\mathrm{Na}$ criação de manifestações culturais de comunidades e povos tradicionais, os membros da comunidade podem, a partir das expressões culturais já existentes, recriar e complementar a obra original. Em tese, tal circunstância poderia enquadrar-se no conceito de obra compósita. No entanto, observa-se uma vez mais que não é possível identificar o(s) autor(es) da obra/manifestação cultural original, tampouco todos os autores da obra derivada. Ou seja, mesmo que se pudesse compreender o processo de criação do patrimônio cultural imaterial como uma constante recriação de manifestações culturais derivadas, percebe-se que ainda assim não seria possível enquadrá-lo como obra compósita dado a impossibilidade de identificação dos autores. 


\subsection{Conclusão}

Diante desse cenário, verifica-se que a manifestação cultural não se enquadra perfeitamente em nenhuma das modalidades de obras plúrimas, tampouco no conceito de obra e, portanto, não poderia ser protegida pelas demais normas de direito de autor, sendo objeto de sua tutela apenas os direitos morais, tal como apresentado neste capítulo. Como sustentado por Carlos Alberto Bittar ${ }^{370}$ e por Antonio Carlos Morato, ${ }^{371}$ o ordenamento jurídico nacional admite a figura da pessoa jurídica autora, especialmente porque, ao instituir direitos ao autor na Constituição, esta não os limitou aos autores pessoas físicas. Ademais, como sustentado por Robert Alexy, ${ }^{372}$ além de um direito da personalidade, o direito moral de autor é direito fundamental, podendo, como tal, ser reconhecido a uma coletividade, a fim de que se tutele a dignidade da pessoa humana, e não apenas a pessoa física.

Dessa maneira, a partir do sustentado por Antonio Carlos Morato, ${ }^{373}$ que a pessoa jurídica pode ser autora e titular originária de direitos morais, entende-se, para os fins do presente trabalho, como consequência, que um povo ou comunidade tradicional, devidamente representada de acordo com suas formas tradicionais - as quais devem ser respeitadas e reconhecidas -, pode ser equiparada a uma pessoa jurídica ou poderia ser de direito uma pessoa jurídica legitimamente constituída, titular de direitos da personalidade, nos termos do artigo 52 do Código Civil, para fins de ser reconhecida como titular originária da manifestação cultural produzida coletivamente pelo povo ou comunidade tradicional, ainda que determinados autores, pessoas físicas, que participam da elaboração não possam ser identificados, posto que o processo de criação é transgeracional.

\footnotetext{
370 BITTAR, Carlos Alberto. Contornos atuais do direito do autor. São Paulo: RT, 1992. p. 36-38.

371 MORATO, Antônio Carlos. Direitos de autor em obra coletiva. 2. ed. São Paulo: Saraiva, 2007. p. 6-9. No prelo.

372 ALEXY, Robert. Colisão de direitos fundamentais e realização de direitos fundamentais no estado de direito democrático. Revista de Direito Administrativo, Rio de Janeiro: Renovar, v. 217, p. 58, jul.-set. 1998.

373 MORATO, Antônio Carlos. Direitos de autor em obra coletiva. 2. ed. São Paulo: Saraiva, 2007. p. 6-9. No prelo.
} 
Assim, embora sejam reconhecidos os direitos morais, próprios do direito de autor, às manifestações culturais, as demais disposições do sistema de direito de autor não podem ser aplicadas com precisão à tutela do patrimônio cultural imaterial. Por esse motivo, ainda que seja possível utilizar-se da legislação de direitos de autor por analogia e como fonte de direito para a tutela dos direitos existentes e protegidos constitucionalmente no âmbito das comunidades e povos tradicionais, faz-se necessária a tutela desses direitos por meio de regulamentação sui generis, visto que a proteção ao patrimônio cultural imaterial dessas comunidades ou povos tradicionais seguramente envolve direitos de autor, direitos morais e da personalidade, além de interesses coletivos, do grupo ao qual pertencem e públicos, pois a manutenção da diversidade cultural interessa a toda a sociedade.

Portanto, respondendo à pergunta apresentada inicialmente - 0 patrimônio cultural imaterial é objeto do direito de autor? -, entendemos que, tal como está estruturado atualmente o direito de autor, este não pode tutelar a proteção do patrimônio cultural imaterial em razão de o objeto do direito de autor, que tutela a criação, conferir proteção a autores identificáveis, enquanto o patrimônio cultural imaterial se caracteriza por ter autoria transgeracional, plural e de difícil - senão impossível - identificação.

Muito embora tenham sido analisadas as obras de autoria plúrima, verifica-se que nenhuma de suas modalidades se assemelha à forma de criação das manifestações do patrimônio cultural imaterial. E, ainda, em função do prazo limitado de proteção concedido à obra tutelada pelo direito de autor, não se pode sustentar a aplicabilidade do direito de autor à tutela do patrimônio cultural imaterial, à exceção dos direitos morais. Ainda sob a perspectiva da natureza jurídica do direito de autor e do patrimônio cultural imaterial, é possível observar a incompatibilidade de o patrimônio cultural ser objeto do direito de autor, porque, embora controversa, este é reconhecido como ramo do direito privado, enquanto a tutela do patrimônio cultural imaterial inserese de maneira mais apropriada como natureza de direito coletivo e interesse público.

Analisando a opinião de doutrinadores sobre a possibilidade de o direito de autor tutelar o patrimônio cultural imaterial, observa-se que, embora Roberto 
Senise Lisboa $^{374}$ considere mais adequado incluir a proteção às obras da tradição cultural no campo do direito de autor, com titular desconhecido, Edson Beas Rodrigues Junior $^{375}$ sustenta que os direitos de autor não podem reger a proteção ao patrimônio cultural imaterial. Por seu turno, José Carlos Costa Netto ${ }^{376}$ afirma que o folclore está mais próximo do conceito de obra coletiva, de titularidade da comunidade que a desenvolveu, do que de obra em domínio público e, ainda, de que o uso de patrimônio cultural com intuito de lucro deve ser precedido de autorização junto a órgão competente para representar a comunidade titular da manifestação cultural. Já o aprofundado estudo de Antônio Chaves ${ }^{377}$ defende que se reconheçam os direitos morais de autor das comunidades tradicionais, bem como se retribua financeiramente sempre que houver a exploração das manifestações culturais, ou sejam usadas como inspiração, para fins comerciais.

A partir desses entendimentos, este trabalho compartilha do entendimento perfilhado por Edson Beas Rodrigues Junior, porém concorda com o reconhecimento da necessidade de autorização da comunidade previamente à exploração da manifestação cultural, como sustenta José Carlos da Costa Netto e com o entendimento de Antônio Chaves sobre a existência de direitos morais detidos pelas comunidades tradicionais autoras, bem como financeiros, na hipótese de exploração comercial da manifestação cultural.

LISBOA, Roberto Senise. A obra de folclore e sua proteção. In: BITTAR, Eduardo C. B.; CHINELLATO, Silmara Juny (Coord.). Estudos de direito de autor, direito da personalidade, direito do consumidor e danos morais: homenagem ao Professor Carlos Alberto Bittar. Rio de Janeiro: Forense Universitária, 2002. p. 52-75.

375 RODRIGUES JUNIOR, Edson Beas. Tutela juridical dos recursos da biodiversidade, dos conhecimentos tradicionais e do folklore: uma abordagem de desenvolvimento social. Rio de Janeiro: Elsevier, 2010. p. 64-74.

376 COSTA NETTO, José Carlos. Direito autoral no Brasil. 2. ed. São Paulo: FTD, 1998. p. 117-118. O autor defende ainda que o folclore não é obra em domínio público e que as "expressões" do folclore são bens tutelados como patrimônio artístico de uma comunidade. Inclusive lembra que a partir da Convenção de Berna passou-se a discutir a possibilidade de construção de um regime sui generis para proteção do patrimônio cultural alicerçado no direito de autor, sendo que foi produzida lei tipo para orientar os países signatários a regular o tema (Tunis, 1976).

377 CHAVES, Antônio. Direitos de autor: princípios fundamentais. Rio de Janeiro: Forense, 1987. p. $80-93$. 
Ante todo o exposto, o fato de se concluir que o direito de autor não se aplica de maneira precisa às manifestações culturais criadas por comunidades e povos tradicionais, não implica reconhecer que tais manifestações não sejam protegidas pelo direito moral ou que não existam outros dispositivos para sua proteção, como será apresentado no capítulo seguinte, a partir da interpretação das normas em vigor conforme a Constituição Federal. 


\section{Capítulo 4}

\section{INTERPRETAÇÃO DA REGULAMENTAÇÃO DO PATRIMÔNIO CULTURAL IMATERIAL CONFORME ${ }^{378}$ A CONSTITUIÇÃO}

A partir do levantamento normativo até aqui realizado, observa-se que não existe no ordenamento jurídico nacional uma norma que trate especificamente da tutela ao patrimônio cultural imaterial. $\mathrm{O}$ que identificamos foram dispositivos constitucionais que garantem direitos e deveres ao Estado, às comunidades e povos tradicionais, bem como convenções internacionais que determinam princípios e condutas a serem seguidos no tratamento e uso do patrimônio cultural imaterial. Portanto, a partir da constatação de que o direito de autor não se presta a tutelar o patrimônio cultural imaterial, será realizada uma interpretação sistemática ${ }^{379}$ das normas identificadas no presente trabalho, conforme a Constituição Federal, a fim de identificar quais os direitos e obrigações que atualmente devem ser atendidos para proteção e uso do patrimônio cultural imaterial. Isso porque, pelo levantamento normativo realizado, constata-se que a ausência de norma específica para regular o patrimônio cultural imaterial não implica a ausência de regulação, como equivocadamente se poderia pensar. A falta de tal norma apenas exige maior esforço interpretativo para que se chegue às obrigações e direitos garantidos por nosso arcabouço legal. E é exatamente esse esforço que será realizado neste capítulo, apresentando as disposições legais que devem ser atendidas para a exploração do patrimônio cultural imaterial de comunidades e povos tradicionais identificáveis. É certo que, por outro lado, mesmo com a interpretação conforme, é possível que se chegue à conclusão de que falta norma específica para tornar a tutela do patrimônio cultural imaterial mais clara e atender aos

\footnotetext{
378 A interpretação conforme é a interpretação sistemática e harmônica da própria Constituição porque não se pode admitir que a Constituição seja contraditória. Assim, necessário realizar uma interpretação da legislação infraconstitucional conforme seus dispositivos. SILVA, Virgílio Afonso da. Interpretação conforme a constituição: entre a trivialidade e a centralização judicial. Revista DireitoGV, São Paulo, v. 2, n. 1, p. 193, jan.-jun. 2006. luz do Código Civil. 2008. Tese (Concurso de Professor Titular de Direito Civil) - Faculdade de Direito da Universidade de São Paulo, São Paulo, p. 227.
} 
dispositivos constitucionais. Por isso, no capítulo seguinte será analisada proposta de projeto de lei para regular o tema e será exposta nossa sugestão de norma sobre o tema.

\subsection{Regime de tutela do patrimônio cultural imaterial: direitos culturais}

Pelo que foi até aqui apresentado, nota-se que a Constituição Federal garante direitos fundamentais, necessários à dignidade da pessoa humana, para as comunidades e povos tradicionais - definidas como os indígenas, afro-brasileiros e outros grupos que contribuem para o processo civilizatório nacional -, bem como assegura direitos à sociedade de acesso à cultura por eles produzida. Justamente por esse duplo feixe de direitos que emana dos dispositivos constitucionais, sustenta-se que existe um feixe de direitos de interesse público, que se destina a toda a sociedade para fins de promover o acesso à cultura, e outro feixe de direitos coletivos, voltado a tutelar os direitos garantidos às comunidades e povos tradicionais.

Assim, para que se compreenda a relevância de se protegerem tais direitos, importa analisar o conceito de bem comum, proposto por Carlos Aurélio Mota de Souza, qual seja o bem que "consiste no justo fim das ações humanas, consistindo em critério de elaboração de leis justas para a convivência social". ${ }^{380}$ A partir dessa conceituação, percebe-se que o bem comum é o objetivo a ser alcançado em uma sociedade, especialmente em relação à gestão do patrimônio cultural imaterial, pois, para que o bem comum de diversidade cultural, difusão e proteção das manifestações culturais seja alcançado, devem-se reconhecer, garantir e proteger os direitos dos grupos "particulares", quais sejam as comunidades e povos tradicionais. É comum o entendimento de que o interesse público conflita com os bens particulares. ${ }^{381}$ Contudo, entendemos que, para a gestão do patrimônio cultural imaterial e a satisfação do interesse comum de acesso à cultura, é exatamente o contrário, devem ser garantidos os bens particulares, isto é, as manifestações culturais das comunidades e povos tradicionais e, uma vez reconhecidos seus direitos, podem passar a integrar o conjunto de bens culturais de interesse público.

\footnotetext{
$\overline{380}$ SOUZA, Carlos Aurélio Mota de. Empresas e empresários à luz dos princípios constitucionais do bem comum. Revista do Instituto dos Advogados de São Paulo, São Paulo: RT, ano 13, n. 25, p. 83109, jan.-jun. 2010.

381 Idem, ibidem, p. 83-109.
} 
A Constituição Federal de 1988 veio exatamente reconhecer a titularidade de direitos culturais desses povos e comunidades tradicionais, no entendimento de Carlos Alberto Molinaro e Fernando Antonio de Carvalho Dantas, ao prever direitos individuais e direitos coletivos em seu artigo $215 .^{382}$ De acordo com o entendimento expressado pelos citados autores, os direitos individuais seriam de titularidade de cada pessoa, a fim de requerer as garantias que lhes são outorgadas em referido artigo constitucional, como acesso à cultura - equivalente ao primeiro feixe de direitos tratado neste trabalho, denominado feixe de direitos de interesse público. Já os direitos coletivos seriam de titularidade das comunidades e povos tradicionais que finalmente passam a ser reconhecidos, coletivamente, como titulares de direitos culturais e como autores de manifestações culturais e sujeitos de direitos relacionados a essas criações - equivalente ao segundo feixe de direitos apresentado anteriormente nesta dissertação, chamado de feixe de direitos coletivos.

Veja-se, portanto, que na visão desses autores existe no $\S 1 .^{\circ}$ do artigo 215 da Constituição Federal um dever ao Estado de proteger as manifestações culturais dos povos e comunidades tradicionais, reconhecendo os direitos dessas populações, "as quais se vinha negando historicamente sua titularidade". ${ }^{383}$ Portanto, em resposta à primeira questão apresentada, qual seja se há a proteção do patrimônio cultural imaterial detido por comunidades e povos tradicionais, conferindo-lhes direitos, a resposta é afirmativa, e esses direitos reconhecidos são os direitos culturais, que pertencem ao gênero dos direitos humanos e, portanto, são direitos fundamentais de segunda geração e definidos como os direitos decorrentes da cultura. A grande inovação na obra desses autores é o reconhecimento de que essa modalidade dos direitos culturais não alcança apenas os indivíduos em seu direito ao acesso à cultura, mas também os povos e comunidades tradicionais enquanto produtores, conservadores $\mathrm{e}$ autores de manifestações culturais, garantindo-lhes o direito de existir segundo sua própria cultura e forma de organização, além de preservar a identidade e integridade de seus grupos,

\footnotetext{
382 MOLINARO, Carlos Alberto; DANTAS, Fernando Antonio de Carvalho. Comentário aos artigos 215 e 216. In: CANOTILHO, J.J. Gomes; MENDES, Gilmar F.; SARLET, Ingo W.; STRECK, Lenio L. (Coord.). Comentários à Constituição do Brasil. São Paulo: Saraiva, 2013. p. 1983-1984. 
reconhecendo tais direitos aos autores de todas as manifestações culturais, artísticas, intelectuais, sejam eles pessoas individuais ou plurais. ${ }^{384}$

Para que a garantia a esses direitos coletivos, destinados a comunidades e povos tradicionais, seja efetiva, necessário identificar quais os limites impostos a terceiros por esses direitos culturais coletivos. Verifica-se, inclusive, que desnecessária qualquer regulamentação infraconstitucional para a defesa desses direitos, uma vez que, por se tratar de direito fundamental e de norma que independe de regulamentação, possui aplicação imediata e deve ser compreendido à luz da interpretação conforme os demais princípios constitucionais.

Dessa maneira, considerando a tutela aos direitos culturais coletivos, isto é, de povos e comunidades tradicionais identificáveis, nos termos do disposto no artigo 215, e o dever de o Estado reconhecer e proteger os direitos culturais a esses povos e, ainda, considerando que tais grupos são compostos de pessoas que também possuem os direitos fundamentais de previstos no artigo 5. ${ }^{\circ}$ da Constituição Federal, como inviolabilidade do domicílio, liberdade e igualdade, bem como os direitos da personalidade, verifica-se que a utilização não autorizada pelos titulares do direito comunidades e povos tradicionais -, de suas manifestações culturais, artísticas ou intelectuais e, bem assim, de seus modos de criar, fazer e viver, representam violação a: (i) direito conferido pela Constituição Federal à proteção e reconhecimento de titularidade de suas manifestações culturais; (ii) seu direito à identidade e integridade, tanto de seus grupos quanto de sua própria pessoa; (iii) direito às suas criações intelectuais; (iv) a seus direitos quanto "autor" das manifestações culturais, ${ }^{385}$ portanto seus direitos morais, uma vez que, embora a produção de manifestação cultural não se enquadre completamente no conceito de direito de autor, sendo os direitos morais direito da personalidade e as manifestações culturais, expressões da personalidade das pessoas que integram determinado povo ou comunidade, conclui-se que essas pessoas, pertencentes à coletividade identificável, possuem direitos morais a serem tutelados e protegidos na exploração da expressão cultural que desenvolveram, ainda que esta obra

\footnotetext{
384 MOLINARO, Carlos Alberto; DANTAS, Fernando Antonio de Carvalho. Comentário aos artigos 215 e 216. In: CANOTILHO, J.J. Gomes; MENDES, Gilmar F.; SARLET, Ingo W.; STRECK, Lenio L. (Coord.). Comentários à Constituição do Brasil. São Paulo: Saraiva, 2013. p. 1984. 
seja intangível, não esteja fixada em um corpo físico e integre o patrimônio cultural imaterial daquele povo ou comunidade. Justamente por esse motivo Carlos Alberto Molinaro e Fernando Antonio de Carvalho Dantas sustentam que há reconhecimento constitucional dos autores das manifestações culturais, sejam individuais ou plurais. E como consequência devem ser reconhecidos os direitos morais desses autores plurais.

\subsubsection{Lei-Modelo}

A partir dos fundamentos e conceitos até aqui apresentados, verifica-se que, embora existam direitos previstos na Constituição destinados a esses povos ou comunidades tradicionais, a inexistência do reconhecimento prático dos direitos desses povos e comunidades tradicionais sobre as manifestações culturais que criaram gera insegurança jurídica e, novamente, prejuízos ao interesse público, que sequer conhece a diversidade de manifestações culturais que existem em seu território, tampouco conhecerá, visto que muitas delas estão se extinguindo sem que sejam compartilhadas.

Assim, para a efetiva aplicação dos direitos garantidos constitucionalmente e superação do entendimento falacioso de que há ausência de tutela dos direitos das comunidades e povos tradicionais - pode não haver norma específica, mas determinados dispositivos já regulam e conferem direitos a essas comunidades quanto a seu patrimônio cultural imaterial -, basta a análise do ordenamento jurídico brasileiro. Este é bastante claro ao garantir proteção às manifestações culturais dos povos e comunidades tradicionais, em âmbito constitucional e como direito fundamental - o que, por si só, já assegura o reconhecimento ao direito coletivo de determinada comunidade a seus bens culturais, não sendo necessária sequer a regulamentação dos dispositivos constitucionais para que se garantam a aplicabilidade de tais direitos. Diante dessa constatação, verifica-se em obra de Antônio Chaves, escrita em 1987, ou seja, antes mesmo das claras disposições constitucionais que tutelaram os direitos coletivos das comunidades e povos locais, que naquela época já se disciplinava como 
deveria se dar a regulamentação ao patrimônio cultural imaterial, então denominado folclore, a partir da Lei Tipo adiante analisada. ${ }^{386}$

A Lei-Modelo da Tunísia sobre direitos de autor para países em desenvolvimento, de 1976, elaborada pela OMPI-Unesco, regulava os direitos de autor com a tutela ao folclore, reconhecendo os direitos morais - de paternidade, de opor-se à deformação, modificação - e patrimoniais sobre a obra, que deveriam ser geridos pelo Estado, por meio da autoridade nacional designada para tanto. ${ }^{387}$ Embora tal Lei Tipo não reconhecesse de forma clara os direitos das comunidades detentoras de bens culturais, já identificava alguns deles e propunha regulamentação do tema para minimizar a insegurança jurídica.

A partir da análise dessa norma, ${ }^{388}$ Antônio Chaves sustenta que o patrimônio cultural deve ter proteção sem limite de prazo e que, em caso de internalização e uso de manifestação cultural de outro país, deve ser obtida a autorização da autoridade competente estrangeira. ${ }^{389}$ Ainda, Antônio Chaves já reconhecia que havia deficiência na regulamentação do patrimônio cultural no país, embora outros doutrinadores sugerissem que, por não ser conhecido o autor da obra pertencente ao "folclore”, esta integraria o domínio público, pertencendo a todos.

Ressalte-se que, à época em que a obra de Antonio Chaves foi elaborada, a LDA ainda não existia, regulando o tema a Lei n. ${ }^{\circ}$ 5.988, de 14 de dezembro de 1973. Essa norma dispunha que eram de domínio público as obras de autor desconhecido, transmitidas pela tradição oral. ${ }^{390}$ Ora, buscava de fato integrar as manifestações culturais ao domínio público, situação severamente alterada pela atual redação do artigo 45 da LDA, como antes analisado. Assim, pela comparação entre a redação instituída pela Lei n. ${ }^{0} 5.988$ de 1973 e a da LDA, confirma-se o entendimento

\footnotetext{
386 CHAVES, Antônio.Direitos de autor: princípios fundamentais. Rio de Janeiro: Forense, 1987. p. 80.

387 Artigo 18, incisos III, IV e IX, da Lei Tipo da Tunísia de 1976. Disponível em: $<$ http://portal.unesco.org/culture/en/files/31318/11866635053tunis_model_law_enweb.pdf/tunis_model_law_en-web.pdf>. Acesso em: 12 jun. 2012. Artigo 6 da Lei Tipo da Tunísia de 1976.

389 CHAVES, Antônio. Direitos de autor: princípios fundamentais. Rio de Janeiro: Forense, 1987. p. 81.

390 Cf. artigo 48, II, da Lei n. ${ }^{\text { }} 5.988 / 1973$.
} 
de que esta garante proteção às obras de autoria desconhecida pertencente às comunidades tradicionais e étnicas, não as reconhecendo como em domínio público.

Retornando à análise de Antônio Chaves, o autor, já em 1987, observou que havia duas classes de direitos relacionados ao folclore, sendo a primeira delas concernente às obras que, de fato, eram de origem não conhecida - e para essas concordava que fossem consideradas de domínio público -, contudo reconhecia que existia "toda uma riqueza cultural que é de origem conhecida embora seja desconhecida a pessoa que o criou. Há uma comunidade que o considera seu patrimônio e o cultiva com amor todo especial". ${ }^{391}$ Por esse motivo, Antônio Chaves entendia que o aproveitamento econômico dessas manifestações culturais de origem conhecida não poderia ser realizado sem que a comunidade de origem fosse reconhecida e também participasse do "sucesso econômico de sua arte", ${ }^{392}$ afirmando, inclusive, que, embora muito novo o tema, já existiam países na África e América do Sul, especialmente a Bolívia, que possuíam forte tendência de garantir uma proteção de direito autoral ou ao menos constituir normas de natureza semelhante para assegurar os direitos da “comunidade de origem" da manifestação cultural. ${ }^{393}$

Diante desse reconhecimento da existência de direitos por parte da comunidade conhecida, detentora de manifestações culturais, mesmo antes do advento do claro Texto Constitucional de 1988, identificam-se os direitos que devem ser garantidos a essas comunidades e povos tradicionais identificáveis sobre suas manifestações culturais, reconhecendo-se que estas não pertencem ao domínio público.

\subsubsection{Direitos morais no patrimônio cultural imaterial}

Neste item pretende-se responder à terceira questão: Existem direitos morais no patrimônio cultural imaterial? Assim, além do disposto na Constituição Federal, que por si só já reconhece direitos e proteção ao patrimônio cultural imaterial

\footnotetext{
391 CHAVES, Antônio. Direitos de autor: princípios fundamentais. Rio de Janeiro: Forense, 1987. p. 83.

392 Idem, ibidem.

393 Idem, p. 84 .
} 
de coletividade identificável, importante observar também as garantias previstas na Declaração Universal dos Direitos do Homem, que em seu artigo 27 prevê:

\section{Artigo 27.}

1. Toda a pessoa tem o direito de tomar parte livremente na vida cultural da comunidade, de fruir as artes e de participar no progresso científico e nos benefícios que deste resultam.

2. Todos têm direito à proteção dos interesses morais e materiais ligados a qualquer produção científica, literária ou artística da sua autoria.

A partir desse dispositivo, observa-se a proteção aos interesses morais garantidos à pessoa, quando houver qualquer produção científica literária ou artística de sua autoria. Ora, na construção do patrimônio cultural, diversas pessoas integrantes da comunidade e povo tradicional contribuem e realizam produções científicas, literárias ou artísticas e, justamente por isso, devem ter seus direitos morais respeitados, ainda que no contexto plural do patrimônio cultural imaterial. Ademais, como ensina Victor Drummond, as comunidades tradicionais possuem características distintas das sociedades complexas, na medida em que valorizam o âmbito coletivo como parte essencial de sua identidade pessoal. ${ }^{394}$ A relação entre homem e coletividade em comunidades tradicionais é tão relevante que qualquer abalo a essa coletividade tem o poder de interferir nos indivíduos que a compõem de maneira a atingir sua honra, sua imagem e, portanto, repercutir em seus direitos da personalidade. ${ }^{395}$

Diante desse cenário, verifica-se que, da mesma forma que foi possível com a evolução da jurisprudência e doutrina admitir que pessoa jurídica possui direito da personalidade, ${ }^{396}$ identificando-se direitos pessoais às pessoas jurídicas, de cunho moral, tal como o direito à identificação e à honra, ${ }^{397}$ deve ser reconhecida a existência

\footnotetext{
394 DRUMMOND, Victor Gameiro. A tutela jurídica das expressões culturais tradicionais. 2001. Tese (Mestrado) - Universidade de Lisboa, Faculdade de Direito, Lisboa, p. 202. No prelo.

395 Idem, ibidem.

396 BITTAR, Carlos Alberto. Teoria geral do direito civil. Rio de Janeiro: Forense Universitária, 1995. p. 140.

397 MORATO, Antônio Carlos. Direitos de autor em obra coletiva. 2. ed. São Paulo: Saraiva, 2007. p. 60-69. No prelo.
} 
de direito da personalidade à coletividade identificável, para fins de garantir direitos morais a essa coletividade, tal como reconhecido às pessoas jurídicas. A esse respeito, Ricardo Luís Lorenzetti ${ }^{398}$ ensina que, muito embora os direitos humanos tenham como titular apenas o homem, por analogia os direitos da personalidade podem ser estendidos à proteção da pessoa jurídica e a de todos os entes coletivos - ora, as comunidades e povos tradicionais podem ser, portanto, incluídos entre os entes coletivos para os quais os direitos da personalidade podem ser estendidos. Aliás, como já indicado no capítulo anterior, as comunidades e povos tradicionais podem ser equiparados a pessoa jurídica, porque, como sustenta Dalmo de Abreu Dallari, “a comunidade indígena é uma forma especial de associação que não se subordina às formalidades exigidas para outras espécies de associações", ${ }^{399}$ portanto deve ser vista como pessoa jurídica sem que haja a necessidade de registros de contratos sociais, pois a legislação garante o respeito às formas tradicionais de organização de povos e comunidades tradicionais. ${ }^{400}$ Tal reconhecimento é essencial na medida em que o sistema jurídico nacional foi construído pela lógica individual para tutela de interesses privados, sendo que para a tutela dos direitos garantidos às comunidades faz-se necessária a adaptação dessa lógica jurídica à proteção e disciplina dessas coletividades. ${ }^{401}$ Portanto, a partir desse raciocínio, já é possível sustentar a existência de determinados direitos da personalidade conferidos às comunidades e povos tradicionais, como pessoas jurídicas.

Entretanto, também sob outras perspectivas, pode-se sustentar a existência de direitos da personalidade às comunidades e povos tradicionais. Nesse sentido, Victor Drummond afirma que o direito da personalidade vem se alterando e ultrapassando a percepção puramente individualista, ${ }^{402}$ de modo a permitir e reconhecer

398 LORENZETTI, Ricardo Luís. Fundamentos do direito privado. Tradução de Vera Maria Jacob de Fradera. São Paulo: RT, 1998. p. 301.

DALLARI, Dalmo de Abreu. Índios, cidadania e direitos. O índio e a cidadania. São Paulo: Brasiliense, 1983. p. 12.

400

Nos termos do artigo $2 .^{\circ}$ do Decreto n. ${ }^{\circ}$ 6.040, de 7 de fevereiro de 2007, que assim dispõe: "Art. 2 . $^{\circ}$ A PNPCT tem como principal objetivo promover o desenvolvimento sustentável dos Povos e Comunidades Tradicionais, com ênfase no reconhecimento, fortalecimento e garantia dos seus direitos territoriais, sociais, ambientais, econômicos e culturais, com respeito e valorização à sua identidade, suas formas de organização e suas instituições".

BARBOSA, Carla G. Antunha; BARBOSA, João M. Antunha; BARBOSA, Marco A. Direito a diferença na sociedade da informação: os direitos indígenas na Constituição brasileira. Revista do Instituto dos Advogados de São Paulo, São Paulo: RT, ano 10, n. 20, p. 62, jul.-dez. 2007. 
sua aplicação também em contextos que superam o indivíduo, tal como nas circunstâncias em que são admitidos direitos da personalidade à pessoa jurídica e a entes coletivos, como direito à imagem e à honra. Partindo-se desses entendimentos, e considerando o reconhecimento de direitos morais à pessoa jurídica autora, como titular originária, conforme anteriormente apresentado, tal como defendido por Antonio Carlos Morato e Carlos Alberto Bittar, pode-se sustentar que a comunidade tradicional identificável pode ser - como ente coletivo - sujeito de determinados direitos da personalidade, tal como ocorre com a pessoa jurídica, como direito à honra, à imagem e a direitos morais de autor.

Como visto anteriormente, a manifestação cultural imaterial criada no âmbito de uma comunidade ou povo tradicional não se enquadra no conceito de obra do direito de autor, especialmente porque não é possível identificar a totalidade dos "coautores" que contribuíram para sua criação e por esse motivo não pode ser tutelado pelo direito de autor. Contudo, é possível reconhecer, pelo ordenamento jurídico brasileiro, que a comunidade ou povo tradicional é sujeito de direitos da personalidade, especialmente direito à honra, imagem e direitos morais, tal como ocorre com a pessoa jurídica. Assim, considerando que há criação intelectual na construção do patrimônio cultural imaterial de comunidades tradicionais, há criatividade e, por fim, identificação do grupo que o criou, ainda que não sejam identificáveis todas as pessoas, verifica-se que existe criação e a necessidade de proteção, assim como na obra de direito de autor, já que a manifestação cultural também é fruto do espírito humano e a violação desta implica em ofensa a direitos da personalidade de todos os indivíduos que compõem a coletividade criadora. Portanto, devem ser garantidos a este grupo criador determinados direitos sobre a "obra" realizada a fim de evitar sua apropriação indevida por terceiros e de violar as manifestações culturais desse grupo e por consequência seus direitos da personalidade, tal como ocorre com a obra criada por autor individual. Estes direitos são inclusive garantidos constitucionalmente, por meio do artigo 216 da Constituição Federal às coletividades criadora. E quais seriam estes direitos? Além dos de personalidade, que proteção recai sobre estas criações que integram o patrimônio cultural imaterial de um povo ou comunidade tradicional?

Considerando que, como analisado anteriormente, a criação de manifestações culturais detidas por um grupo não se enquadra nos conceitos e escopo 
do direito de autor, poder-se-ia pensar que não haveriam quaisquer direitos intelectuais incidentes sobre esta criação coletiva. Contudo, dado que a Constituição Federal garante em seu artigo $5^{\circ}$, inciso XXVII que "aos autores pertence o direito exclusivo de utilização, publicação ou reprodução de suas obras, transmissível aos herdeiros ${ }^{403}$ pelo tempo que a lei fixar", sem definir o que deve ser entendido por "autores" é possível sustentar que a LDA, por ser norma infraconstitucional, não pode ser interpretada de forma a restringir direitos garantidos constitucionalmente. Desta maneira, dado que não existe definição do que vem a ser autor e que os conceitos apresentados na LDA não esgotam o tema - como se pode constatar pelo fato de a Lei do Software incluir no sistema de proteção do Direito de Autor nova modalidade de obra e, portanto, novo conceito de autor - conclui-se que a Constituição Federal pátria admite a possibilidade de no escopo do conceito de autor ser incluído o povo ou comunidade tradicional como criador e titular originário da manifestação cultural que gera. Evidente que para tanto seria necessária a criação de norma que viesse regular a definição de autor, incorporando à interpretação do conceito constitucional, a comunidade ou povo tradicional como autora da manifestação cultural que criou.

Necessário destacar que nesta hipótese, a norma que viesse a regular o conceito de direito de autor, para incluir as manifestações culturais, deveria prever o regramento específico que seria aplicado a estas criações coletivas, respeitando suas particularidades e o fato de não ser possível identificar a totalidade de seus autores individuais, criando-se regramento específico e sui generis para acomodar o tratamento ao tema, novamente, tal como ocorreu com a Lei do Software ${ }^{404}$.

Adicionalmente, muito embora lei específica pudesse disciplinar outro regramento para proteção de direitos intelectuais de povos e comunidades tradicionais no escopo dos direitos de autor, até que isto venha a ocorrer, novamente se coloca a questão: há direitos intelectuais garantidos ao povo ou comunidade tradicional que cria

403 Nem se alegue que a menção a "herdeiros" neste dispositivo constitucional possa levar à interpretação de que autor somente poderia ser pessoa física, tal debate já foi superado e como anteriormente mencionado neste trabalho, na atualidade reconhece-se a possibilidade de a pessoa jurídica ser autora, tal como sustenta Antônio Carlos Morato. Dado que os povos e comunidades tradicionais podem ser equiparados a pessoas jurídicas, admissível como hipótese que estes podem ser titulares de direito de autor.

404 BRASIL, Lei $\mathrm{n}^{\mathrm{o}} 9.609$, de 19 de fevereiro de 1998. Disponível em <http://www.planalto.gov.br/ccivil_03/leis/19609.htm>. Acesso em 6 abr. 2014. 
manifestações culturais? Dado que inexiste norma para tratar especificamente da questão, necessário voltar-se a outras fontes de direito e por meio da interpretação sistêmica do ordenamento jurídico pátrio, verificar se outras normas podem ser aplicadas a este tema de modo a suprir esta lacuna legal. Assim, nos termos da Lei de Introdução às normas do Direito Brasileiro 405 , “quando a lei for omissa, o juiz decidirá o caso de acordo com a analogia, os costumes e os princípios gerais de direito", desta maneira, neste trabalho buscar-se-á a aplicação destas fontes de direito a fim de suprir a lacuna existente para definir se há direitos intelectuais e, especialmente, morais de autor sobre o patrimônio cultural imaterial detidos pelos povos e comunidades tradicionais que participam de sua criação.

Considerando que há uma hierarquia entre as fontes formais ${ }^{406}$ de direito, sendo as leis superiores aos costumes, e que o Direito não pode ser minucioso a ponto de detalhar todas as hipóteses e circunstâncias em que pode vir a ser aplicado ${ }^{407}$, dado que há lacuna legislativa no tratamento ao direito garantido constitucionalmente às comunidades e povos tradicionais que criam manifestações culturais, este trabalho partirá para a análise dos costumes, mais especificamente da analogia, como forma de eliminar tal omissão.

A analogia consiste na aplicação de normas relativas a situações análogas, para viabilizar a solução de um novo caso, cujo tratamento não está previsto em lei, embora o direito seja garantido constitucionalmente. Como preceitua Carlos Maximiliano, a analogia "se baseia na presunção de que duas coisas que tem entre si um certo número de pontos de semelhança possam consequentemente assemelhar-se quanto a um outro mais" ${ }^{408}$. Ocorre que a analogia somente pode ser aplicada para determinadas situações e, ainda, se preencher certos requisitos, do contrário não haveria processo indutivo rigoroso e a conclusão jurídica levaria o aplicador a equívocos ${ }^{409}$. Desta forma, para uso da analogia deve haver uma situação não prevista no

405 BRASIL, Decreto-Lei no 4.657, de 4 de setembro de 1942. Disponível em <http://www.planalto.gov.br/ccivil_03/decreto-lei/Del4657compilado.htm>. Acesso em 6 abr. 2014.

406 GOMES, Orlando. Introdução ao direito civil. 10. Ed. Rio de Janeiro: Forense, 1992, p. 40-52.

407 MAXIMILIANO, Carlos. Hermenêutica e aplicação do direito. Rio de Janeiro: Forense, 2005, p. 168-175.

408 Idem, ibidem, p. 168.

409 Idem, ibidem, p. 169. 
ordenamento jurídico e esta deve ser semelhante à outra contemplada no texto legal. Ocorre que tal semelhança deve estar atrelada ao elemento essencial que deu origem ao dispositivo que se pretende aplicar por analogia e, portanto, a nova situação deve ser equivalente em seu cerne e efeitos com a situação para a qual já há norma que a tutele.

Ora, dado que o direito de autor busca proteger a obra, bem como garantir direitos àquele que a criou e que, nos termos do artigo 216 da Constituição Federal, a criação que integra o patrimônio cultural imaterial também deve ser protegida, sendo que uma manifestação cultural desenvolvida por comunidade ou povo tradicional é também uma criação intelectual humana, que produz como resultado “obras" ou expressões idênticas àquelas produzidas por um autor individual, verifica-se que há real igualdade entre o cerne do direito de autor e o do patrimônio cultural imaterial detido por povos e comunidades identificáveis, especialmente porque o conteúdo da manifestação cultural pode ser substancialmente equivalente ao conteúdo de direito de autor, já que aquele pode ser criativo e de valor estético, como o de direito de autor. Ainda, muito embora pudesse sustentar que a manifestação cultural não está fixada em um suporte físico, como a obra de direito de autor, observa-se que aquela está fixada na linguagem oral do povo ou comunidade tradicional que a criou e, portanto, pode ser entendida como manifestação que possui corpo místico e corpo mecânico, ainda que este seja a linguagem oral. Desta forma, verifica-se que as manifestações culturais criadas por povos e comunidades tradicionais possuem características essenciais semelhantes à obra de Direito de Autor, atendendo a este requisito para a utilização da analogia para suprir lacuna legislativa relativa à tutela do patrimônio cultural imaterial.

Contudo, outros requisitos ainda devem ser atendidos para utilização da analogia, como aplicar norma da mesma natureza jurídica ao novo caso ${ }^{410}$. Assim, em sendo a matéria objeto da lacuna, de direito civil, não lhe deve ser aplicada legislação tributária de forma análoga. Neste tocante, para avaliar o cumprimento a este requisito necessário comparar as naturezas jurídicas do patrimônio cultural imaterial e do direito de autor, tal como apresentado anteriormente neste trabalho. Observa-se que a natureza

410 MAXIMILIANO, Carlos. Hermenêutica e aplicação do direito. Rio de Janeiro: Forense, 2005, p. 168-175. 
jurídica do segundo feixe de direitos decorrentes da proteção constitucional do patrimônio cultural imaterial possui natureza jurídica de direitos fundamentais. Já no tocante ao direito de autor, foi apresentado que este não possui natureza jurídica de privilégio ou de propriedade, mas sim é um direito único, composto de direito de personalidade - o direito moral -, que também é direito fundamental, e direito patrimonial, havendo imbricação entre ambos. Assim, também este requisito é preenchido, na medida em que há coincidência da natureza jurídica entre a nova hipótese - tutela do patrimônio cultural imaterial de povos identificáveis - e a norma que se pretende aplicar por analogia - direitos garantidos aos autores, especialmente os morais.

Ainda, avaliando-se os requisitos para a utilização da analogia, tem-se que legislações excepcionais - que não se confundem com especial ou particular ${ }^{411}$ - e penais não admitem a aplicação por analogia, dado que específicas para determinada situação, não admitem extensão para novas situações. Como a legislação aplicável ao direito de autor não se enquadra quer em legislação excepcional, quer penal, conclui-se que este requisito também foi atendido para a aplicação a novas hipóteses por analogia. Adicionalmente, Carlos Maximiliano sustenta também que a analogia não se aplica em matéria de privilégios ou a normas que limitam direitos ou liberdade ${ }^{412}$. Como este trabalho analisou anteriormente, verifica-se que nem o direito de autor, tampouco o patrimônio cultural imaterial referem-se a privilégios, motivo pelo qual este requisito também é atendido para fins de aplicação da analogia pretendida.

Por fim, a analogia somente pode ser utilizada para situações em que não se crie direito novo, mas apenas se "descobre o já existente"413. Ora tal entendimento é pertinente, sob pena de se poder admitir que a analogia poderia criar direitos não previstos pelo legislador, chegando-se ao absurdo de que seria possível ampliar o escopo da Constituição Federal por meio da analogia, o que não pode ser admitido. Assim, considerando que os direitos garantidos aos povos e comunidades tradicionais sobre suas manifestações culturais são garantidos constitucionalmente, a

\footnotetext{
411 MAXIMILIANO, Carlos. Hermenêutica e aplicação do direito. Rio de Janeiro: Forense, 2005, p. 173.

412 Idem, ibidem, p. 173-176.

413 Idem, ibidem, p. 174.
} 
analogia pode ser utilizada para descobrir a extensão destes direitos, sem violar esta premissa para aplicação da analogia.

Desta forma, evidencia-se a possibilidade de se aplicar, por analogia, as normas que tutelam o Direito de Autor à proteção das manifestações culturais criadas por povos e comunidades tradicionais identificáveis, sempre que seu processo criativo e resultado for análogo ao de Direito de Autor.

Desta forma, aplicando-se, por analogia, a proteção aos direitos morais de autor à criação de uma manifestação cultural, já que os direitos morais de autor que possuem natureza jurídica de direitos fundamentais, tal como o direito ao patrimônio cultural imaterial, faz-se necessário avaliar quem é o titular desses direitos. Considerando que o processo de criação da manifestação cultural ocorre necessariamente em função da coletividade existente no povo ou comunidade tradicional, uma vez constatado que essa coletividade expressa para as pessoas que a compõem a sua própria identidade e valores íntimos, ${ }^{414}$ verifica-se que a comunidade tradicional realiza criação em nível diferenciado, ${ }^{415}$ proporcionando meios físicos, psíquicos e culturais para que a criação ocorra de forma coletiva. Assim, por contribuir com a criação de modo objetivo, enquanto seus membros realizam a criação de maneira subjetiva, a comunidade tradicional detém a titularidade originária sobre as manifestações culturais produzidas em seu ambiente e, portanto, passa a ser titular de direitos morais sobre essas manifestações culturais criadas por seus membros, tal como a pessoa jurídica detém direitos morais na obra coletiva de que é titular. Para os fins deste trabalho, esses direitos morais serão denominados como direitos morais do patrimônio cultural imaterial e são estes os direitos garantidos às coletividades criadoras, por analogia ao disposto na LDA.

E esses direitos morais incluem, em analogia aos direitos de autor, os direitos de paternidade, que, ao serem aplicados ao patrimônio cultural imaterial, devem ser entendidos como o direito de autorizar o uso - ou não - de determinada

\footnotetext{
414 DRUMMOND, Victor Gameiro. A tutela jurídica das expressões culturais tradicionais. 2001. Tese (Mestrado) - Universidade de Lisboa, Faculdade de Direito, Lisboa, p. 203. No prelo.

415 MORATO, Antônio Carlos. Direitos de autor em obra coletiva. 2. ed. São Paulo: Saraiva, 2007. p. 69. No prelo.
} 
manifestação por terceiros e o direito de ter a origem da manifestação cultural informada. E tal autorização e indicação de origem seriam conferidas pelas comunidades ou povos tradicionais identificáveis que tenham produzido as manifestações culturais, ou seja, reconhece-se que determinada manifestação cultural originou-se daquela comunidade ou povo tradicional e que este pode permitir ou não seu uso e exploração, tal como já sustentado por Antonio Chaves em sua obra de 1987.416

Muito embora o atendimento a tal direito possa parecer complexo, dado que a identificação da origem de determinada manifestação cultural e a obtenção de sua autorização possam parecer desafiadoras, vale ressaltar que hoje a legislação nacional, por meio da Medida Provisória n. ${ }^{\circ}$ 2.186-16, de 23 de agosto de 2001, já estabelece a obrigatoriedade de se indicar a origem do acesso ao conhecimento tradicional associado a patrimônio genético e da obtenção da anuência da comunidade que provê o conhecimento tradicional à instituição interessada. Ou seja, para o uso de conhecimento tradicional associado a patrimônio genético - conhecimento este que integra o patrimônio cultural imaterial como já analisado no Capítulo $2-$, o interessado deve entre outras obrigações - informar a origem do conhecimento utilizado. ${ }^{417}$ Ora, se esse tratamento já é dispensado a essa modalidade de conhecimento tradicional, integrante expressamente do patrimônio cultural imaterial, como dispõe o artigo $8 .^{\circ}, \S 2 .^{\circ},{ }^{418}$ por

416 CHAVES, Antonio. Direitos de autor: princípios fundamentais. Rio de Janeiro: Forense, 1987. p. 81.

417 Art. 9. À comunidade indígena e à comunidade local que criam, desenvolvem, detêm ou conservam conhecimento tradicional associado ao patrimônio genético, é garantido o direito de:

I - ter indicada a origem do acesso ao conhecimento tradicional em todas as publicações, utilizações, explorações e divulgações;

II - impedir terceiros não autorizados de:

a) utilizar, realizar testes, pesquisas ou exploração, relacionados ao conhecimento tradicional associado;

b) divulgar, transmitir ou retransmitir dados ou informações que integram ou constituem conhecimento tradicional associado;

III - perceber benefícios pela exploração econômica por terceiros, direta ou indiretamente, de conhecimento tradicional associado, cujos direitos são de sua titularidade, nos termos desta Medida Provisória.

Parágrafo único. Para efeito desta Medida Provisória, qualquer conhecimento tradicional associado ao patrimônio genético poderá ser de titularidade da comunidade, ainda que apenas um indivíduo, membro dessa comunidade, detenha esse conhecimento.

$418 \S 2 .^{\circ}$ O conhecimento tradicional associado ao patrimônio genético de que trata esta Medida Provisória integra o patrimônio cultural brasileiro e poderá ser objeto de cadastro, conforme dispuser 
que outras modalidades de manifestações culturais integrantes do patrimônio cultural imaterial não gozam da mesma proteção? Evidente que tal obrigatoriedade de comunicação de origem do patrimônio cultural existe como medida de proteção aos direitos morais e, portanto, de personalidade, da comunidade tradicional que cria a manifestação cultural e deve ser estendida ao uso de todas as manifestações culturais detidas por comunidades vivas e identificáveis. A existência do referido dispositivo na citada medida provisória apenas reforça a necessidade de respeito a esse direito moral e evidencia que a identificação da origem pode e deve ser realizada.

Analisando, ainda, a Medida Provisória n. ${ }^{\circ}$ 2186-16/2001, observa-se que há a previsão de que essa norma protege o conhecimento tradicional das comunidades indígenas e das comunidades tradicionais contra utilização ilícita e que o Estado reconhece que essas comunidades possuem o direito de decidir sobre o uso de seus conhecimentos tradicionais associados ao patrimônio genético. ${ }^{419}$ Ora, tais dispositivos apenas expressam os direitos e o reconhecimento de titularidade, garantidos pela Constituição Federal, às comunidades tradicionais sobre suas manifestações culturais que integram o patrimônio cultural imaterial e que podem ser chamados de direitos morais de paternidade. Ainda que esses dispositivos se refiram especificamente ao conhecimento tradicional associado a patrimônio genético, eles traduzem garantias constitucionais que se aplicam a todas as manifestações culturais integrantes do patrimônio cultural imaterial e sejam detidas por comunidades e povos tradicionais vivos e identificáveis. Assim, pode-se verificar que esses dispositivos também devem ser aplicados a todo o patrimônio cultural imaterial detido por comunidades e povos tradicionais vivos e identificáveis, até porque o Direito não poderia admitir entendimento diverso, uma vez que as manifestações culturais produzidas e de titularidade de comunidades determinadas e identificáveis pertencem àquele grupo e compõem a sua cosmologia, crenças e identidade, especialmente a identidade cultural $^{420}$

o Conselho de Gestão ou legislação específica.

419 Nos termos do artigo 8..$^{\circ}$ da Medida Provisória n. ${ }^{\circ}$ 2.186-16/2001.

420 Conforme a Declaração de Istambul, de 2002, o patrimônio cultural imaterial está ligado à identidade cultural porque "constitui um conjunto vivo e em perpétua recriação de práticas, saberes e de representações, em todas as escalas da sociedade, de exprimir maneiras de conceber o mundo através de sistemas de valores e sinais étnicos" (BARBOSA, Carla G. Antunha; BARBOSA, João M. Antunha; BARBOSA, Marco A. Direito a diferença na sociedade da informação: os direitos indígenas na Constituição brasileira. Revista do Instituto dos Advogados de São Paulo, São Paulo: RT, ano 10, n. 20, p. 44, jul.-dez. 2007). 
- como indivíduos e como coletividade, não poderia ser admitida a apropriação dessas manifestações culturais por terceiros, de maneira não autorizada, sob pena de violar os direitos constitucionais garantidos à comunidades e povos tradicionais, bem como os direitos de personalidade, à honra, à imagem e a direitos morais reconhecidos à coletividade, a partir do entendimento mais abrangente dos direitos da personalidade, já apresentado anteriormente neste capítulo.

Em alinhamento com o entendimento anteriormente apresentado, tomamos a liberdade de transcrever doutrina que reconhece a necessidade de autorização da comunidade ou povo tradicional titular de sua manifestação cultural para sua utilização, nos seguintes termos: ${ }^{421}$

\begin{abstract}
Não seria juridicamente razoável afirmar que povos indígenas não têm direito sobre as suas criações artísticas, ou que as mesmas estejam desprotegidas. Se o patrimônio imaterial indígena pudesse ser apropriado livremente, sem qualquer tipo de autorização, seu significado poderia ser indevidamente alterado e sua sacralidade desrespeitada, e os povos indígenas pouco poderiam fazer. Porém, se a Constituição Federal, que é a Lei maior do país, garante a esses povos direitos sobre o seu patrimônio material e imaterial, não pode a lei impedir tal proteção.
\end{abstract}

Ainda na concepção dos direitos morais de paternidade, observa-se que até mesmo para a obra caída em domínio público deve ser garantido ao autor o direito de ter seu nome ligado à obra. ${ }^{422}$ Assim, mesmo que o patrimônio cultural imaterial não possa ser considerado como integrante do domínio público quando se identifica comunidade ou povo tradicional que detém sua titularidade, ainda que o fosse deveriam ser garantidos os direitos morais de paternidade. Portanto, com maior razão devem ser reconhecidos se, como demonstrado, não integram o domínio público, sob pena, inclusive, de gerar obrigação de indenizar por danos morais aquela comunidade ou povo que tem sua manifestação cultural explorada sem a indicação de origem ou com a

\footnotetext{
BAPTISTA, Fernando Mathias; VALLE, Raul Silva Telles. Os povos indígenas frente ao direito autoral e de imagem. São Paulo: Instituto Socioambiental, 2004. p. 19.

422

CHINELlATO, Silmara Juny de Abreu. Direito de autor e direitos da personalidade: reflexões à luz do Código Civil. 2008. Tese (Concurso de Professor Titular de Direito Civil) - Faculdade de Direito da Universidade de São Paulo, São Paulo, p. 166 -167.
} 
autoria atribuída a outra pessoa. A esse respeito, necessário ponderar que, na hipótese de a titularidade da manifestação ser atribuída a outra comunidade ou povo tradicional, deve ser avaliado com cautela se houve erro quanto à indicação de origem ou se, em realidade, trata-se de manifestação cultural detida por mais de uma comunidade ou povo tradicional, situação muito comum entre os povos tradicionais e que implica limitação ao direito de paternidade, como será detalhado a seguir.

Para tratar dessa situação, em que mais de uma comunidade ou povo tradicional detém a mesma manifestação cultural, deve ser identificado junto a qual povo ou comunidade ela foi obtida, ${ }^{423}$ isto é, conhecida, e essa comunidade provedora deve ser indicada como origem da manifestação cultural, ainda que outras também a detenham. ${ }^{424}$ Normalmente, quem explora ou utiliza manifestação cultural a conhece por meio de bibliografia ou por visitas em campo. Portanto, seja na bibliografia que indique a origem da manifestação cultural ou a partir da identificação das comunidades que foram objeto de visita em campo, o usuário de manifestação cultural deve identificar a origem e a titularidade da manifestação cultural, fazendo referência à comunidade que proveu a informação ou a manifestação cultural. Essa medida é prevista em norma que trata dos conhecimentos tradicionais associados a patrimônio genético e se faz necessária como forma de garantir a rastreabilidade da manifestação cultural, permitindo sua difusão e contribuindo para sua perpetuidade visando à garantia da diversidade cultural.

Caso outras comunidades ou povos considerem que aquela divulgação não indica corretamente a origem da manifestação cultural, ou de alguma forma viola sua cultura, crenças, valores, ou que a origem é em realidade de seu povo ou comunidade, deve buscar a tutela do Estado, inclusive por meio do Poder Judiciário,

Esse procedimento é o que deve ser adotado para a identificação da comunidade provedora de conhecimento tradicional associado, nos termos do regime instituído pela citada Medida Provisória n. ${ }^{\circ}$ 2.186-16/2001. Assim, como esse mecanismo já é aplicado ao conhecimento tradicional, que está contido no conceito de patrimônio cultural imaterial, o mesmo procedimento deve ser seguido para definição de direitos relacionados às demais manifestações culturais detidas por comunidades ou povos tradicionais.

Nos termos do artigo 9. ${ }^{\circ}$ da Medida Provisória n. ${ }^{\circ}$ 2.186-16/2001 (BRASIL. Medida Provisória n. ${ }^{\circ}$ 2.186-16, de 23 de agosto de 2001. Disponível em: <http://www.planalto.gov.br/ccivil_ 03/mpv/2186-16.htm>. Acesso em: 12 mar. 2014). 
para amparar e defender seus direitos de paternidade. Contudo, considerando que mais de uma comunidade pode possuir a mesma manifestação cultural, o direito de paternidade deve sofrer limitações e por esse motivo pode haver o entendimento de que a indicação de origem deve se limitar a indicar o povo ou comunidade tradicional em que a manifestação cultural foi conhecida, e não todas as demais comunidades que detêm a mesma manifestação cultural.

Os direitos morais no patrimônio cultural imaterial incluem, ainda, o direito de inédito, dado que deve ser conferido às comunidades tradicionais o direito de não concordarem com a exposição e divulgação de sua manifestação cultural, ${ }^{425}$ quer, por exemplo, em função de sua sacralidade ou por não desejarem a exploração econômica de suas manifestações culturais.

Os direitos morais no patrimônio cultural compreendem, também, os direitos à integridade da manifestação cultural, conferindo direitos à comunidade ou povo tradicional de impedir a modificação da expressão, o que poderia implicar violação à honra ou reputação da comunidade, bem como à sua imagem. $\mathrm{O}$ direito à integridade compreende, inclusive, a necessidade de que se obtenha a autorização da comunidade ou povo, segundo sua forma tradicional de representação, para a realização de obras derivadas a partir da manifestação cultural. Necessário observar que tal direito existe para a tutela do feixe de direitos coletivos, ou seja, para a proteção à comunidade ou povo tradicional identificável e não para aquelas manifestações culturais cuja titularidade ou origem não mais se possa identificar ou relacionar a uma comunidade ou povo determinável.

Ainda, necessário compreender a limitação a esses direitos morais no patrimônio cultural imaterial, uma vez que os membros da comunidade ou povo tradicional que detém a manifestação cultural podem ao longo do tempo alterar sua percepção sobre o direito de inédito e a possibilidade de modificação ou não da manifestação cultural, e, ainda, os membros da comunidade podem individualmente desejar produzir e divulgar obras pessoais criadas a partir da manifestação cultural e

BARBOSA, Carla G. Antunha; BARBOSA, João M. Antunha; BARBOSA, Marco A. Direito a diferença na sociedade da informação: os direitos indígenas na Constituição brasileira. Revista do Instituto dos Advogados de São Paulo, São Paulo: RT, ano 10, n. 20, p. 48, jul.-dez. 2007. 
permitir modificações em suas obras individuais. É evidente que nessa hipótese, caso a obra individual implique exploração não autorizada pela própria comunidade ou povo tradicional de seu patrimônio cultural, esta poderá insurgir-se contra seu integrante, valendo-se das regras internas para dirimir a questão, e na sua falta recorrendo até mesmo ao Poder Judiciário para dirimir o conflito.

Por outro lado, os direitos morais no patrimônio cultural imaterial não incluiriam os direitos de modificar a obra, pois o patrimônio cultural imaterial é composto por manifestações em constante processo de reconstrução e recriação, logo, inerente ao seu conceito a mudança dessas manifestações. Por esse motivo, não haveria a necessidade de se garantir um direito moral à modificação da manifestação cultural porque esta é uma característica própria da criação das expressões integrantes do patrimônio cultural imaterial. Da mesma forma, os direitos morais no patrimônio cultural imaterial não incluiriam os direitos de arrependimento e retirada de circulação, pois, em razão da natureza do patrimônio cultural imaterial, i.e., por ser "obra" intangível - e que portanto não pode ser retirada de circulação -, uma vez divulgada, passa a ser do conhecimento de todos e não pode deixar de ser conhecida. Ademais, em função da natureza de direito público, que garante à sociedade o direito de ter acesso à cultura, uma vez divulgada a manifestação cultural, esta passa a integrar o rol de manifestações conhecidas pela sociedade. No entanto, caso a comunidade tradicional venha a autorizar exploração comercial de determinada manifestação cultural, em relação a esta autorização específica, são possíveis o exercício do direito de arrependimento e a consequente suspensão na autorização de uso da manifestação cultural pela contraparte.

Uma vez identificados, portanto, direitos morais no patrimônio cultural imaterial, dado que neste trabalho se sustenta a teoria monista, deve-se também considerar que a partir desses direitos morais, visto que os titulares dos direitos culturais concordem com sua divulgação - não exercendo, portanto, o direito de inédito -, surge o direito patrimonial atrelado às criações do patrimônio cultural, e, no caso de patrimônio cultural imaterial, por envolver os dois feixes de direitos já citados neste trabalho, de direito difuso e coletivo, o direito patrimonial poderia ser exercido quando 
houvesse interesse na utilização da manifestação cultural para fins comerciais. ${ }^{426}$ Por seu turno, quando houver a intenção de mera divulgação da manifestação cultural imaterial, sem finalidade econômica, deve ser obtida a autorização junto à comunidade titular para tanto, mas, uma vez obtida sua anuência, não deveriam ser exercidos direitos patrimoniais em benefício da comunidade, pois a mera divulgação autorizada das manifestações culturais, divulgando sua origem, integra o feixe de direitos de interesse público, previstos e garantidos constitucionalmente em benefício de toda a sociedade, é o direito à informação e conhecimento da manifestação cultural. ${ }^{427}$

A partir da interpretação conforme das disposições legais previstas no ordenamento jurídico nacional com a Constituição, é possível responder à terceira pergunta e afirmar que existem direitos morais, como os identificados anteriormente, aplicáveis à proteção do patrimônio cultural imaterial. Assim, o reconhecimento de proteção e necessidade de autorização do titular de determinada manifestação cultural para seu uso é também a interpretação mais adequada do dispositivo constitucional e da LDA porque promove o bem comum. Dado que a busca por autorização dos detentores de determinada manifestação cultural implica o respeito ao direito moral de ter a origem identificada e a possibilidade de uso do patrimônio cultural em linha com as crenças e valores daqueles que o criaram, conservam e o detêm - contribuindo para sua difusão e não deturpação -, e, ainda, em retribuição, na medida em que a obtenção de benefícios pela exploração do patrimônio cultural imaterial pode também remunerar aquele que permaneceu conectado à sua terra e à sua cultura e conservou a manifestação cultural que agora é conhecida e utilizada pela sociedade, o que se observa é um ciclo, em que o fim é a promoção do bem comum e incentivo para valorização do trabalho de manter modos tradicionais de vida, que retroalimentam a sociedade com novos impulsos, saberes e manifestações culturais.

\footnotetext{
426 CHAVES, Antonio. Direitos de autor: princípios fundamentais. Rio de Janeiro: Forense, 1987. p. 9.

427 Reitera-se que não é objetivo deste trabalho tratar dos direitos patrimoniais no patrimônio cultural imaterial, embora ele possa ser mencionado a fim da completa análise do tema.
} 


\subsection{Dificuldades na proteção ao patrimônio cultural imaterial e violações de direitos em seu uso}

As principais dificuldades a serem enfrentadas para proteção do patrimônio cultural imaterial envolvem a superação do entendimento de que estes bens culturais são integrantes do domínio público, com o entendimento de que seriam pertencentes a toda a sociedade e a dificuldade de se fixar prazo para a tutela desses direitos. De acordo com o apresentado no presente trabalho, de fato uma vertente dos direitos previstos na Constituição refere-se ao interesse público, contudo há outra vertente, destinada a garantir e reconhecer os direitos dos povos e comunidades tradicionais, que inclusive é excetuada do domínio público nos termos da própria LDA.

Por esse motivo, o grande desafio para a proteção do patrimônio cultural imaterial dessas comunidades e povos tradicionais é o reconhecimento de que estes possuem direitos, tal como de personalidade, direitos morais, garantidos também constitucionalmente, ainda que para autores não identificáveis e a definição quanto ao prazo de duração dessa proteção.

Para respondermos de maneira completa à primeira questão apresentada neste trabalho, necessário tratarmos dessas duas dificuldades - reconhecimento de que o patrimônio cultural imaterial de comunidades ou povos identificáveis não integra o domínio público - e a questão do prazo de proteção. Assim, serão avaliados o conceito de domínio público e sua delimitação pelo artigo 45 da LDA. Em seguida, será compreendida a forma de produção dessas manifestações culturais para avaliar seu prazo de duração.

$\mathrm{O}$ artigo 45 da LDA estabelece que:

Art. 45. Além das obras em relação às quais decorreu o prazo de proteção aos direitos patrimoniais, pertencem ao domínio público:

I - as de autores falecidos que não tenham deixado sucessores;

II - as de autor desconhecido, ressalvada a proteção legal aos conhecimentos étnicos e tradicionais. 
Importante observar que o domínio público incide em duas hipóteses: sobre obras de direito de autor cujos autores não tenham deixado sucessores - ou seja, reconhece-se a autoria, porém após falecimento do autor não são identificados titulares para seguir exercendo os direitos patrimoniais ainda garantidos ao autor -, ou então na hipótese de autor desconhecido, isto é, quando não se sabe quem criou a obra em questão. Veja-se que nesse inciso o legislador ainda faz expressamente a ressalva de que, mesmo nos casos de autoria desconhecida, devem ser excepcionadas do domínio público aquelas obras protegidas no escopo do conhecimento étnico e tradicional. Ora, embora as terminologias utilizadas não sejam precisas, a partir da interpretação sistemática desta norma, conforme a Constituição Federal e as definições trazidas pelas Convenções da Unesco, verifica-se que a "proteção legal aos conhecimentos étnicos e tradicional" nada mais é que a proteção garantida constitucionalmente ao patrimônio cultural imaterial dos povos e comunidades tradicionais que contribuem no processo civilizatório nacional.

Portanto, há a clara previsão de que o patrimônio cultural imaterial não integra o domínio público quando estiver no escopo da proteção constitucional. E, como já indicado neste trabalho, o patrimônio cultural imaterial protegido sob o feixe de direitos coletivos, pela Constituição Federal, é aquele cuja titularidade pode ser identificada e atribuída à comunidade ou povo tradicional. Nesse sentido, além de ser possível identificar a titularidade e a vinculação da manifestação cultural com comunidade ou povo tradicional específico, é fundamental que essa comunidade esteja viva, ${ }^{428}$ isto é, que não tenha se extinguido. Isso porque, caso embora seja possível identificar a titularidade do patrimônio cultural imaterial, mas se verifique que tal titular já está extinto, haverá enquadramento, por analogia, na hipótese do inciso I do artigo 45 da LDA, em que se reconhece a autoria, mas não existem mais pessoas ou comunidade legitimada a exercer os direitos garantidos. Logo, não integram o domínio público, nos termos do artigo 45 da LDA, as manifestações culturais cuja titularidade seja identificada e atribuída a comunidade ou povo tradicional, desde que este ainda esteja

428 DRUMMOND, Victor Gameiro. A tutela jurídica das expressões culturais tradicionais. 2001. Tese (Mestrado) - Universidade de Lisboa, Faculdade de Direito, Lisboa, p. 59. No prelo. 
vivo e não tenha sido objeto de extinção. Caso não seja possível identificar a titularidade - quer porque a manifestação já está difundida e não se vincular a nenhuma comunidade específica, quer porque se desconhece de fato qualquer titular -, ou se identificado o titular, verificar-se que este está extinto, chegaremos à conclusão de que essas manifestações culturais, as quais chamaremos de manifestações culturais difundidas, pertencem ao domínio público. Cabe destacar o conceito de domínio público, que não deve ser entendido como domínio do Estado, mas sim como obras em domínio do público, ${ }^{429}$ isto é, de todos e sujeitas à tutela prevista na LDA, ${ }^{430}$ mediante a qual cabe ao Estado defender a integridade e autoria da obra caída em domínio público, não permitindo a apropriação indevida por terceiros.

No que diz respeito ao prazo de duração da proteção às manifestações culturais, deve ser avaliado se tais direitos são sujeitos a limitações temporais ou não. Victor Drummond defende que, para se responder a esse questionamento concernente à duração desse direito, deve-se primeiramente avaliar como surge a proteção às manifestações culturais. ${ }^{431}$ De acordo com esse doutrinador, tal proteção não decorre da criação da manifestação cultural, tal como no caso do direito de autor, até porque não é possível precisar o momento dessa criação que pode ter ocorrido no passado, em tempos imemoriais ou até mesmo no presente. Assim, a tutela ao patrimônio cultural imaterial passa a existir a partir do momento em que se identifica a origem da manifestação cultural, i.e, quando passa a ser possível vinculá-la a comunidade ou povo tradicional identificável.

No entanto, para fins de determinação do momento em que surge a proteção, deve-se verificar também se tal comunidade ou povo tradicional identificado ainda existe. Dessa forma, para que se possa considerar a existência de proteção à manifestação cultural, necessário avaliar se há identificação de comunidade que seja sua titular, bem como se esta se encontra viva, sendo positiva a resposta a ambos os requisitos, deverá haver proteção às suas manifestações culturais enquanto a

\footnotetext{
429 CHINELlato, Silmara Juny de Abreu. Direito de autor e direitos da personalidade: reflexões à luz do Código Civil. 2008. Tese (Concurso de Professor Titular de Direito Civil) - Faculdade de Direito da Universidade de São Paulo, São Paulo, p. 225.

430 Conforme dispõe o artigo $24, \S 2 .^{\circ}$, da LDA.

431 DRUMMOND, Victor Gameiro. A tutela jurídica das expressões culturais tradicionais. 2001. Tese (Mestrado) - Universidade de Lisboa, Faculdade de Direito, Lisboa, p. 249. No prelo.
} 
comunidade for identificável e estiver viva. Assim sendo, constata-se que a garantia aos direitos sobre o patrimônio cultural imaterial a determinada comunidade ou povo tradicional deve viger por prazo indeterminável, enquanto se mantiverem essas duas condições acima expostas. Portanto, observa-se que não há prazo determinado para sua vigência, tampouco se trata de direito ad aeternum.

Tal entendimento de que a tutela ao patrimônio cultural imaterial deve viger por prazo indeterminado está, inclusive, alinhado com o interesse público de que tais direitos tenham, de fato, tratamento diferenciado quanto a seu prazo de duração. Isso porque, se é reconhecido que o direito exclusivo do autor se justifica para retribuir e remunerar quem cria, de modo a estimular a continuar realizando investimentos para o desenvolvimento de novas obras estéticas, ainda mais razão existe para que se garantam direitos semelhantes às comunidades e povos tradicionais. Ora, o interesse da sociedade não é manter as comunidades tradicionais vivas, produzindo, protegendo e compartilhando suas manifestações culturais com o restante da sociedade para garantia da diversidade cultural? Pois bem, diferentemente da obra autoral, que é mais uma obra a ser desenvolvida de forma normalmente individual pelo autor, uma manifestação cultural pode levar décadas, séculos para ser desenvolvida, podendo perdurar por períodos ainda mais longos, o que é extremamente desejável para a sociedade, a fim de manter a diversidade cultural, bem como seu vínculo com a memória e identidade histórica.

Justamente por esse motivo, a proteção dessas manifestações por prazos determinados poderia levar a um resultado nefasto para a produção cultural de uma sociedade, pois, se a proteção às manifestações culturais possui prazo inferior ao tempo de existência da própria manifestação e da comunidade à qual pertence, a sociedade estará incentivando o desmantelamento da comunidade após o transcurso da proteção, dado que não haveria a "produção" imediata de manifestação cultural, e, sem o reconhecimento aos direitos morais e a justa retribuição à utilização desses bens culturais, não há estímulo para que os jovens dessas comunidades e povos tradicionais permaneçam exercendo os ofícios e rituais de seus pais e avós, o que certamente 
demanda muito tempo de aprendizagem e formação, que os priva de outros tipos de ensinamentos. $^{432}$

Assim, se a manifestação cultural dessas comunidades e povos tradicionais deixa de ser ensinada e transmitida oralmente e de render frutos - não apenas patrimoniais, como também e principalmente frutos culturais que permitem a manutenção de um povo e de seu modo de vida -, para a subsistência das pessoas que desenvolveram e mantêm a manifestação cultural, elas acabarão se dedicando a outras atividades, provavelmente de produção, não relacionadas ao patrimônio cultural, e aquelas manifestações vão se perder no tempo e espaço, gerando prejuízos à identidade e diversidade cultural daquele povo ou comunidade tradicional, bem como de todo o País.

\subsubsection{Dificuldades da tutela dos patrimônios culturais imateriais em um caso prático}

São comuns as manifestações artísticas nas comunidades e povos tradicionais. Os indígenas Wajãpi, por exemplo, agrupamento de aproximadamente 650 pessoas localizado no rio Içana no Amazonas, têm uma forma particular de expressão artística consistente no uso de pinturas corporais e padrões gráficos denominada Arte Kusiwa. ${ }^{433}$ Essa arte, no entanto, existe no meio desse povo há gerações, não sendo possível precisar qual membro, exatamente, foi seu criador, mesmo porque a própria arte sofre constantes modificações. É inegável que o artista do Povo Wajãpi que executa uma pintura corporal em outro membro ou em outro suporte é autor. A pintura executada por ele (que podemos chamar de obra) só foi possível em razão da existência de todo um arcabouço de conhecimentos tradicionais, que remonta a tempos imemoriais. Esses conhecimentos, no entanto, não se confundem com a obra em si, pois

\footnotetext{
432 Conforme carta do Povo Wajãpi constante do dossiê integrante do processo de registro da Arte Kusiwa, conforme disponível em: <http://www.iphan.gov.br/bcrE/pages/folProcessoRegistroE.jsf>. Acesso em: 29 abr. 2012.

433 Referência ao Dossiê Wajãpi no IPHAN. A Arte Kusiwa dos Wajãpi foi o primeiro bem cultural étnico de população indígena registrado no Livro dos Saberes do Patrimônio Imaterial do IPHAN. Cf. ROTMAN, Mônica; CASTELLS, Alicia Norma González de. Patrimônio e cultura: processos de politização, mercantilização e construção de identidades. Disponível em: $<$ http://www.abant.org.br/conteudo/livros/PatrimonioCultural.pdf $>$. Acesso em: 3 jul. 2012.
} 
são autêntica expressão do patrimônio cultural imaterial, protegido pela Constituição e Convenção de 2003 da Unesco, mencionadas anteriormente.

Assim, estamos diante de dois institutos que, repetimos, não se confundem: a obra executada pelo artista Wajãpi, individualmente considerado, em um determinado momento do tempo (a qual deve ser, individualmente, objeto de proteção do direito de autor), e o patrimônio cultural imaterial detido pelos indígenas Wajãpi utilizado pelo artista para a confecção de sua obra. O primeiro instituto é claramente tutelado pela Lei de Direitos Autorais e o segundo, especialmente pela Constituição Federal e Convenção para Salvaguarda do Patrimônio Cultural Imaterial da Unesco, de 2003.

Agora, a questão que se coloca é: se entidade privada deseja fazer uso das manifestações culturais do Povo Wajãpi para fins comerciais, como deve se dar esse processo? Bastaria citar o processo de inscrição dessas manifestações culturais junto ao Livro dos Saberes do IPHAN? Ou seja, seria reconhecido que tais expressões gráficas que notoriamente pertencem e foram desenvolvidas pelo Povo Wajãpi, ainda que não se possam precisar todos os autores, e por nenhum outro - integram o domínio público e poderiam ser utilizadas até mesmo para fins comerciais sem que fosse necessário reconhecer quaisquer direitos à comunidade ou povo tradicional detentor dessa manifestação cultural? E, mais, as expressões gráficas materializadas não foram executadas por uma pessoa que possui direitos de autor pela obra desenvolvida?

Não nos parece que a tutela unicamente pelo direito de autor, para proteção do autor individual de cada expressão do grafismo Wajãpi, seja o mecanismo mais adequado, nem que fora pensado pela Constituição Federal para tanto. Mesmo porque o indivíduo integrante do Povo Wajãpi pode até desejar alienar seus direitos patrimoniais sobre a obra que executou para a exploração por terceiros. Contudo, bastaria a cessão de direitos desse único indivíduo para o uso legítimo do grafismo? Ou seja, não caberia um direito coletivo ao Povo Wajãpi para autorizar ou não o uso de suas expressões culturais gráficas, que guardam simbologia e significados diferenciados para tal povo ${ }^{434} \mathrm{E}$, ainda, sabendo-se que a execução da obra pelo indivíduo pertencente ao

434 Instituto do Patrimônio Histórico e Artístico Nacional - IPHAN, Arte Kusiwa. Disponível em: 
Povo Wajãpi só foi possível por conta da bagagem e conteúdo cultural comum existente naquele povo, o qual foi e vem sendo construído com a participação de todos os seus integrantes, até mesmo aqueles já falecidos de gerações passadas, a retribuição financeira ao direito patrimonial do indivíduo que executou a obra parece ser justa e suficiente?

Ora, pelo levantamento legislativo realizado no presente trabalho e a partir dos direitos identificados para a tutela do patrimônio cultural imaterial, verifica-se que, independentemente de uma manifestação cultural estar ou não registrada, ela deve ser protegida e pode ser tutelada por todos os direitos relatados no presente trabalho. A condição para tanto é que essas manifestações possam ter sua origem identificada e relacionada a uma comunidade ou povo tradicional identificável, e que essa comunidade ou povo exista nos tempos atuais. Caso uma dessas condições não seja preenchida, entendemos que a manifestação integra o domínio público - o que não significa que não há tutela que a proteja, pois mesmo sobre a obra em domínio público incidem alguns direitos morais, e ela não é passível de apropriação por terceiros.

Portanto, no caso das manifestações culturais do povo indígena Wajãpi, verifica-se que elas possuem titular identificável e que está vivo, e, por isso, os direitos morais do patrimônio cultural devem ser garantidos e respeitados quando se desejar divulgar ou explorar qualquer expressão desse patrimônio cultural imaterial. Dessa forma, caso uma universidade desejasse realizar estudo antropológico divulgando os grafismos Wajãpi, bem como a cosmologia relacionada a essa manifestação cultural para esse povo, deveria obter sua autorização para o desenvolvimento desse estudo. Destaca-se que, mesmo se não houver finalidade comercial, ainda assim existe direito moral do titular da manifestação cultural que deve ser respeitado, como o direito de paternidade e inédito, e, portanto, a autorização para uso da manifestação cultural deve ser obtida. No tocante à representatividade da comunidade ou povo indígena, para fins dessa autorização, importante destacar que, para identificação das pessoas e autoridades competentes e representativas da comunidade ou povo tradicional, devem ser seguidas e respeitadas as formas tradicionais de organização da coletividade envolvida; não sendo possível, adotam-se as regras do direito civil de representação.

<http://www.iphan.gov.br/bcrE/pages/folBemCulturalRegistradoE.jsf>. Acesso em: 12 abr. 2012. 
Nesse sentido, Juliana Santilli trata da forma de representação de comunidades ou povos tradicionais com precisão, no trecho a seguir que tomamos a liberdade de transcrever: ${ }^{435}$

A legitimidade para representar um povo indígena, quilombola ou população tradicional em uma autorização de acesso só pode ser estabelecida valendo-se das normas e critérios internos desses povos. A enorme sociodiversidade brasileira impede a adoção de uma norma homogênea ou critério único de representação - afinal, são centenas de povos indígenas, quilombolas e populações tradicionais, com enormes diferenças étnicas e culturais entre si, vivendo em distintos ecossistemas.

Evidentemente, as normas de representação individual ditadas pelo nosso Direito Civil são inapropriadas para contemplar a enorme diversidade de sistemas de representação dos povos tradicionais. Alguns povos indígenas, por exemplo, se fazem representar por seus caciques e chefes, cujos atributos para o exercício do poder variam, como idade, experiência, espírito guerreiro, aptidão para xamanismo, habilidades para caça, pesca e agricultura. Outros povos indígenas, entretanto, conferem o poder político decisório aos conselhos de anciãos. O Direito estatal brasileiro deve, portanto, se limitar a reconhecer e conferir validade jurídica a essa forma de representação. A criação, pelo direito brasileiro, de mecanismos de consulta que não atendam às formas próprias de organização e representação dos povos tradicionais só produzirá divisões internas.

Caso a universidade buscasse a autorização do autor individual do grafismo, somente poderia tratar daquela única obra produzida pelo autor individual e não poderia abordar todo o patrimônio cultural imaterial detido pela comunidade ou povo tradicional. Ainda assim, a comunidade poderia insurgir-se, segundo suas normas internas, contra a autorização pessoal concedida pelo autor da obra individual. Interessante observar, ainda, que, no dossiê constante dos documentos apresentados ao IPHAN para o registro dessa manifestação cultural, pode ser identificado que todos os grafismos integrantes da Arte Kusiwa, registrados como patrimônio cultural imaterial, possuem a assinatura de seu autor Wajãpi, ${ }^{436}$ corroborando a proteção individual do executor ou intérprete da obra decorrente do patrimônio cultural imaterial coletivo.

\footnotetext{
435 SANTILLI, Juliana. Socioambientalismo e novos direitos. São Paulo: Peirópolis, 2005. p. 225. 
Ainda, na hipótese de a utilização desses grafismos ocorrer com fins comerciais, além do reconhecimento e respeito aos direitos morais, a comunidade ou povo tradicional faz jus ao exercício de seus direitos patrimoniais ${ }^{437}$ sobre a manifestação cultural, como sustentado por Antônio Chaves, ${ }^{438}$ ainda que não haja - e que nos pareça necessária - norma específica regulamentado os direitos patrimoniais relacionados às manifestações culturais, e deve receber repartição dos benefícios auferidos por aquele que explorar seu patrimônio cultural imaterial, de acordo com os termos livremente negociados entre comunidade e parte interessada.

Pelo disposto na Constituição Federal, nas convenções internacionais e a partir da interpretação conforme da legislação nacional, é evidente que, embora a LDA não seja aplicável para tutelar os direitos culturais relacionados às manifestações culturais de comunidades ou povos tradicionais, existem direitos morais garantidos ao titular de manifestações culturais - isto é, às comunidades vivas e identificáveis, titulares originárias dos direitos morais do patrimônio cultural imaterial, em função das previsões constitucionais e do artigo 45 da LDA, que exclui expressamente as manifestações culturais do conceito de domínio público.

\subsection{Disposições identificadas para uso do patrimônio cultural imaterial}

A partir do levantamento da legislação vigente aplicável ao patrimônio cultural imaterial, detido por comunidades e povos tradicionais identificáveis, e de sua interpretação conforme a Constituição Federal, é possível concluir que são garantidos os seguintes direitos às comunidades e povos tradicionais que criam manifestações culturais: (i) reconhecimento de que tal patrimônio cultural imaterial não é um bem de todos, mas sim uma manifestação da cultura e, portanto, da identidade de determinada comunidade e dos indivíduos que a compõem, e, como tal, não pode ser objeto de apropriação sem a autorização de seu titular; (ii) reconhecimento de que a comunidade

Acesso em: 4 abr. 2013.

437 O objetivo da presente dissertação de mestrado não é abordar os direitos patrimoniais relacionados ao patrimônio cultural imaterial. Por esse motivo, não serão apresentadas reflexões a respeito da temporalidade desses direitos culturais patrimoniais e se eles também estariam previstos sob o manto da LDA. Apenas indicamos o entendimento de Antonio Chaves ao qual nos filiamos.

438 CHAVES, Antonio. Direitos de autor: princípios fundamentais. Rio de Janeiro: Forense, 1987. p. 81-84. 
ou povo tradicional vivo e identificável possui titularidade originária sobre a manifestação cultural e por isso deve ser consultado previamente ao uso, exploração ou divulgação dela, sendo obtida sua autorização; (iii) reconhecimento de que a comunidade ou povo tradicional que possui a titularidade originária sobre a manifestação cultural possui direitos morais sobre ela, o que inclui o direito de paternidade, o direito de inédito e à integridade da obra, e tais direitos morais encontram limitações sempre que outras comunidades ou povos tradicionais também vivos e identificáveis detiverem a mesma manifestação cultural.

No tocante a direitos patrimoniais, como anteriormente mencionados, parece-nos que há necessidade de norma regulamentadora que trate especificamente deles. Contudo, mesmo sem o advento de tal regulamentação já é possível verificar que na hipótese de uso das manifestações culturais, cuja titularidade originária seja de comunidade viva e identificável, para fins não comerciais, bastariam a obtenção da autorização e o consentimento do titular dos direitos morais sobre a manifestação cultural para seu uso. Por outro lado, na hipótese de uso comercial, ainda que não haja norma prevendo a obrigatoriedade de pagamento, na opinião de Antônio Chaves, além da autorização para uso, seria apropriada a retribuição patrimonial.

As disposições acima retratadas refletem as obrigações que já devem ser atendidas, de acordo com a interpretação conforme dos dispositivos legais existentes no ordenamento jurídico pátrio, para utilização de manifestação cultural imaterial detida por comunidade viva e identificável. Além dessas previsões, de acordo com as orientações OMPI-Unesco, contidas na Lei-Modelo, bem como em conformidade com os ensinamentos de Antônio Chaves ${ }^{439}$ e de Julia Elena Fortún, ${ }^{440}$ um regulamento ideal e completo para o tratamento do patrimônio cultural imaterial deveria reconhecer minimamente os seguintes direitos às comunidades ou povos titulares originários de patrimônio cultural imaterial: reconhecimento dos direitos morais e patrimoniais dessas manifestações culturais à comunidade tradicional, sempre que identificável, ou à

\footnotetext{
439 CHAVES, Antônio. Direitos de autor: princípios fundamentais. Rio de Janeiro: Forense, 1987. p. 93.

440 FORTÚN, Julia Elena. Palestra proferida à Primeira Conferência Continental de Direito de Autor, IIDA, RDI, v. 1, n. 1, apud CHAVES, Antônio. Direitos de autor: princípios fundamentais. Rio de Janeiro: Forense, 1987. p. 93.
} 
autoridade competente, quando não identificável, o que seria, em nosso entendimento, o domínio público remunerado; direito à compensação às comunidades e povos tradicionais pelo reconhecimento de sua contribuição, que pode ser financeira, por meio de apoios e transferência de tecnologias; reconhecimento das comunidades tradicionais - uma ou mais, desde que façam provas - como sujeito de direitos sobre a manifestação cultural; registro da manifestação cultural, por meio de procedimento simplificado, com anuência de seu detentor e por demanda também da própria comunidade ou povo tradicional; uma vez realizado o registro, a manifestação passa a ser de conhecimento público, sendo reconhecido que, sempre que for citada, utilizada como inspiração ou explorada, será necessário respeitar os direitos morais e patrimoniais, especialmente indicação de origem da comunidade ou povo tradicional; implementação do domínio público remunerado ${ }^{441}$ para a tutela das obras cuja origem não é possível identificar; integração entre o banco de dados que registram as manifestações culturais com os órgãos que registram direitos de autor e desenhos industriais, para que se evitem o plágio e a violação aos direitos das comunidades e povos tradicionais.

Para compreensão da proposta antes delineada, importante compreender o que seria o domínio público remunerado. Trata-se de sistema em que se estabelece a obrigatoriedade de pagamento ao Estado para utilização das manifestações culturais que se encontram em domínio público. Se o domínio público remunerado é utilizado como única forma de tutelar o patrimônio cultural imaterial, acaba por não reconhecer a titularidade originária das comunidades e povos tradicionais, uma vez que reconhece que cabe ao Estado o direito de cobrar e gerir a receita decorrente do uso das manifestações culturais, sejam estas de titularidade identificável ou não. Por outro lado, se o domínio público remunerado é visto como uma das formas de se tutelar o patrimônio cultural imaterial, ${ }^{442}$ como ocorre em Burkina Faso, e aplicável apenas para as situações em que a manifestação cultural encontra-se realmente em domínio público e há titularidade derivada do Estado, ${ }^{443}$ este pode ser um instrumento interessante para

441 DRUMMOND, Victor Gameiro. A tutela jurídica das expressões culturais tradicionais. 2001. Tese (Mestrado) - Universidade de Lisboa, Faculdade de Direito, Lisboa, p. 205-209. No prelo.

442 Idem, ibidem, p. 112.

443 Em Burkina Faso o domínio público remunerado incide nas situações em que não se identifique a origem da manifestação cultural, mas se sabe que é de Burkina Faso ou quando, ainda que identificável, a manifestação cultural já tenha esgotado seu prazo de proteção (DRUMMOND, Victor Gameiro. A tutela jurídica das expressões culturais tradicionais. 2001. Tese (Mestrado) - 
garantir o reconhecimento de que as manifestações culturais, ainda que não possam ter sua origem identificada, não são apropriáveis e devem reverter em algum tipo de remuneração ao Estado, quando forem utilizadas, para que este possa investir a receita recebida na conservação dessas manifestações culturais.

Pelo exposto, conclui-se que a partir da interpretação sistemática da Constituição Federal, com as disposições da LDA e Convenções Unesco, existem determinados direitos que já estão garantidos às comunidades e povos tradicionais vivos e identificáveis detentores de manifestações culturais, que devem ser atendidos, sempre que se desejar utilizar essas manifestações culturais, seja para fins comerciais ou não. São estes: o reconhecimento das comunidades vivas e identificáveis como titulares originárias de manifestações culturais; o reconhecimento de que essas comunidades possuem direitos morais sobre o patrimônio cultural que desenvolvem e conservam, e que essas manifestações culturais não podem ser utilizadas indiscriminadamente, sem o prévio consentimento de seu titular.

Por outro lado, a despeito das normas já em vigor, a regulamentação ideal das manifestações culturais imateriais ainda está longe de ser alcançada no ordenamento jurídico nacional e envolveria o tratamento de outros direitos e temas, em conformidade com direitos e princípios consagrados pelas Convenções Unesco, bem como na Lei-Modelo OMPI-Unesco sobre esse tema. Justamente por esse motivo, esta dissertação pretende apresentar proposta de regulamentação do patrimônio cultural imaterial que venha traduzir os direitos identificados por meio da interpretação conforme ora realizada, bem como complementar os direitos e obrigações relacionados ao uso e conservação das manifestações culturais imateriais integrantes do patrimônio cultural imaterial. 


\section{Capítulo 5}

\section{PROPOSTA DE REGULAMENTAÇÃO DO PATRIMÔNIO CULTURAL IMATERIAL}

\subsection{Análise de Projeto de Lei}

Foi elaborado projeto de lei de autoria do Sr. Luiz Piauhylino, ${ }^{444}$ que propõe a regulamentação do patrimônio cultural imaterial, com o reconhecimento de determinados direitos mencionados neste trabalho. A proposta é analisar referido projeto de lei, muito embora sua tramitação já tenha sido arquivada, ${ }^{445}$ apresentando sugestões de alteração e modificação para que ele possa refletir as conclusões que serão obtidas no presente estudo, a fim de dispor sobre a proteção do patrimônio cultural imaterial da forma mais adequada à luz da Constituição e das normas infralegais aplicáveis, com a ressalva de que, mesmo com a inexistência de norma específica para regular o patrimônio cultural imaterial, se verifica que ele já conta com proteção jurídica e determinados direitos garantidos às comunidades e povos tradicionais, nos termos apresentados no capítulo anterior.

Primeiramente, cumpre observar que o projeto de lei pretende ampliar a proteção de direito de autor para incluir a tutela às manifestações culturais produzidas por grupos e comunidades. Essa norma define patrimônio cultural imaterial, tal como na Constituição Federal, e estabelece conceito bastante abrangente que inclui as tradições, expressões orais, expressões artísticas, práticas sociais, rituais e atos festivos, além de conhecimentos e práticas relacionados à natureza e ao universo, técnicas artesanais tradicionais e instrumentos, objetos, artefatos, lugares culturais associados às práticas e expressões, conhecimentos, vivências culturais coletivas do trabalho, da religiosidade, do lazer e da vida social e técnicas referentes às manifestações da cultura imaterial.

444

BRASIL, Projeto de Lei n. 7.684 de 2006. Disponível em <http://www.camara.gov.br/ proposicoesWeb/prop_mostrarintegra;jsessionid=D095E70A2B4358EC67B427034B483D4C.propo sicoesWeb1?codteor $=431559 \&$ filename $=P L+7684 / 2006>$. Acesso em: 5 abr. 2014.

445

Em 31 de janeiro de 2007, conforme informação da Câmara dos Deputados. Disponível em: $<$ http://www.camara.gov.br/proposicoesWeb/fichadetramitacao?idProposicao=338981 $>$. Acesso em: 5 abr. 2014. 
Ademais, o projeto de lei cria uma nova modalidade de obra no âmbito do direito de autor, qual seja a obra comunitária, definida como "manifestação cultural de natureza imaterial e de origem difusa que revele as formas de expressão e os saberes das comunidades tradicionais ou da cultura popular, frutos de herança cultural, em que o indivíduo e/ou grupo sejam meros intérpretes", ${ }^{446}$ e estabelece como sujeito de direitos de autor as comunidades e grupos produtores de obras comunitárias, definidos como o "conjunto de pessoas que partilham as mesmas referências culturais e reconhecem uma identidade comum que desejam preservar ou desenvolver". 447

Ainda, o projeto de lei prevê que o Estado protegerá o patrimônio cultural brasileiro por meio de inventários, registros, vigilância, tombamento e desapropriação, estabelecendo que a comunidade deverá manifestar seu consentimento como condição para a inclusão da manifestação cultural no inventário, respeitando, assim, o direito moral de inédito identificado anteriormente, reconhecendo que o interesse público de que aquela manifestação cultural seja inventariada e difundida não pode violar o interesse da coletividade que criou aquela manifestação cultural.

Esse projeto de lei estabelece, ainda, que o inventário terá como uma de suas funções a certificação de procedência cultural e geográfica das manifestações da cultura imaterial de origem difusa, prevendo que a inclusão no inventário não é condição para sua proteção legal. Há também a obrigação de que a obra comunitária tenha a sua origem e autoria indicadas sempre que for objeto de publicação ou reprodução, demonstrando, por esse dispositivo, o reconhecimento aos direitos morais de paternidade, i.e., de ter a origem da manifestação cultural reconhecida e indicada. Inclusive, o projeto de lei prevê expressamente, em caso de descumprimento desse dispositivo, a responsabilidade por perdas e danos, de acordo com a lei civil e penal. Ou seja, tal artigo evidencia um direito já existente atualmente, o de ter a titularidade e a origem da manifestação cultural reconhecidas, bem como o direito à reparação pelos danos ocasionados na hipótese de violação a esses direitos.

\footnotetext{
446 Conforme dispõe o artigo $7 .^{\circ}$ do Projeto de Lei.

447 Conforme dispõe o artigo $7 .^{\circ}$ do Projeto de Lei.
} 
O projeto de lei prevê também a obrigatoriedade de se obter autorização dos autores da obra comunitária quando se pretender realizar a exploração econômica da manifestação cultural, devendo ser fixada a remuneração para tal uso. Há, ainda, a previsão de que é ilícito o uso ou divulgação das obras comunitárias sem autorização ou que não respeitem a autorização concedida, sujeito a crime de perdas e danos.

Esse projeto de lei de fato cria um regime sui generis específico para a tutela do patrimônio cultural imaterial dentro do conceito de direito de autor e prevê que os direitos patrimoniais dos autores de obras comunitárias não estão sujeitos à limitação temporal, prevendo que a transmissão desses direitos relativos às obras comunitárias dar-se-á de geração a geração, somente no âmbito dessas comunidades ou grupos, não fazendo qualquer referência à transmissão por meio da sucessão.

A esse respeito, interessante observar que o projeto de lei considera os direitos patrimoniais como não sujeitos à limitação temporal, sem mencionar os direitos morais. Todavia, entendemos que o projeto de lei nada menciona a respeito dos direitos morais, justamente porque estes são imprescritíveis e permanecem válidos e vigentes mesmo para as obras de direito de autor sujeitas à proteção com limite temporal. Ainda no tocante à inexistência de limitação temporal para a tutela do patrimônio cultural, entendemos que o projeto poderia deixar mais claro que esse é um direito por prazo indeterminado, para não gerar a percepção de que se trata de um direito eterno, condicionado à identificação da comunidade ou povo tradicional e garantia de que este permanece vivo e que não houve sua extinção.

Ainda analisando o projeto de lei, ele prevê o reconhecimento de direitos patrimoniais dos autores de obras comunitárias, estabelecendo que associações representantes das comunidades e dos grupos produtores realizarão a gestão desses direitos e devem ser aplicados em benefício da comunidade produtora. Nesse aspecto, parece-nos que a norma poderia respeitar as formas tradicionais de organização das comunidades e prever que o próprio grupo poderia definir a gestão dos recursos recebidos pela exploração da manifestação cultural, bem como sua forma de aplicação, independentemente da existência de associações. 
A partir da análise dos artigos desse projeto de lei, observa-se que este busca incluir a tutela do patrimônio cultural imaterial no escopo do direito de autor. Como já foi objeto de análise no Capítulo 3, as características do patrimônio cultural imaterial não permitem, a nosso ver, a interpretação de que o direito de autor se prestaria a regular esses direitos culturais. Por esse motivo, a proposta desse projeto de lei não nos parece a maneira mais acertada de regulação do patrimônio cultural imaterial, porque, se este viesse a se tornar lei, o patrimônio cultural imaterial seria tutelado pelo direito de autor, e, a partir do estudo histórico e doutrinário desse instituto, afigura-se-nos evidente que essa seria uma adaptação forçada, que deturparia o instituto do direito de autor - como para alguns já o faz a lei do software - e submeteria, de forma antinatural, o processo de criação coletivo das manifestações culturais à lógica da tutela individual prevista na proteção de direito de autor, com inserções que alteram significativamente o direito de autor, tal como a inclusão do conceito de obra comunitária, bem como a previsão de direito não sujeito à limitação temporal.

Portanto, muito embora do ponto de vista normativo o projeto de lei possa viabilizar uma tutela mais clara ao patrimônio cultural, entendemos que esta não deve se dar no âmbito do direito de autor, mas sim por meio de norma específica e própria para regular o tema. De toda forma, realizada a ressalva sobre a inclusão do patrimônio cultural imaterial no âmbito do direito de autor, deve-se considerar que a proposta apresentada nesse projeto de lei em diversos outros aspectos reflete os direitos relativos ao patrimônio cultural imaterial que foram identificados no presente trabalho a partir da interpretação das normas nacionais conforme a Constituição Federal, tal como os direitos morais da comunidade ou povo tradicional que cria a manifestação cultural. Assim, a partir da proposta apresentada pelo projeto de lei ora analisado, será exposta adiante proposta de norma para regular e reconhecer os direitos já existentes à tutela do patrimônio cultural imaterial de comunidades ou povos tradicionais identificáveis, enquadrando a proposta de norma como um regime sui generis, necessário para tutelar essa modalidade de direito intelectual, e não no escopo do direito de autor. 


\subsection{Proposta de regime sui generis aplicável ao patrimônio cultural imaterial}

Muito embora seja possível identificar normas e dispositivos legais que regulam o patrimônio cultural imaterial no atual ordenamento jurídico nacional, há a clara necessidade de que se crie norma específica para disciplinar o patrimônio cultural imaterial de modo a evitar interpretações equivocadas dos dispositivos constitucionais e da própria LDA que possam levar ao equivocado entendimento de que o patrimônio cultural imaterial de comunidades e povos tradicionais não possui proteção ou que integra o domínio público.

Em função da natureza jurídica do patrimônio cultural imaterial, por envolver direito fundamental e o duplo feixe de direitos - o difuso e coletivo -, em razão das características particulares dos direitos culturais relacionados às comunidades e povos tradicionais - i.e., seu processo de criação coletivo, transgeracional -, para que seja possível tutelar os direitos morais, bem como o direito à retribuição e a questão relativa ao eventual prazo de duração desses direitos patrimoniais, verifica-se a necessidade de regime sui generis, dado que a proteção do patrimônio cultural imaterial não se enquadra plenamente na tutela conferida ao direito de autor, embora possam ser reconhecidos direitos morais no patrimônio cultural imaterial de comunidades ou povos tradicionais vivos e identificáveis.

Logo, apresenta-se a seguir a proposta de regulamentação ao patrimônio cultural imaterial, especialmente para disciplinar os direitos relacionados aos povos e comunidades tradicionais vivos e identificáveis detentores de manifestações culturais. Em função da preferência terminológica adotada por Carlos Alberto Bittar, que denomina de direitos intelectuais aqueles decorrentes da ligação entre autor e sua obra, ${ }^{448}$ e em função da terminologia adotada por Juliana Santilli no trecho a seguir transcrito, ${ }^{449}$ denominaremos essa proposta de regulamentação dos direitos intelectuais coletivos:

\footnotetext{
448 BITTAR, Carlos Alberto. Os direitos da personalidade. 5. ed. atual. por Eduardo Carlos Bianca Bittar. Rio de Janeiro: Forense Universitária, 2001. p. 138-140.

449 SANTILLI, Juliana. Socioambientalismo e novos direitos. São Paulo: Peirópolis, 2005. p. 213.
} 
O conceito de propriedade - o direito do proprietário de usar, gozar e dispor da coisa, e de reavê-la do poder de quem quer que injustamente a possua ou detenha - é excessivamente estreito e limitado para abranger a complexidade dos processos que geram a inovação, a criatividade e a inventividade nos contextos culturais em que vivem povos indígenas, quilombolas e populações tradicionais. No direito ocidental, a propriedade - tanto sobre bens materiais quanto sobre imateriais - é um direito essencialmente individual e de conteúdo fortemente econômico e patrimonial, e, ainda quando se trata de propriedade coletiva ou condominial, cada cotitular do direito é plenamente identificável. Os processos inventivos e criativos de tais populações são, por essência, coletivos, e a utilização das informações, ideias e recursos gerados com base em tais processos é amplamente compartilhada; portanto, a concepção de um direito de propriedade - pertencente a um indivíduo ou a alguns indivíduos determinados - é estranha e contrária aos próprios valores e concepções que regem a vida coletiva em tais sociedades. Por tal razão é que se defende a adoção do conceito de "direitos intelectuais coletivos" (ou comunitários), para excluir a propriedade, em virtude do seu caráter exclusivista, monopolístico e individualista.

A partir desse entendimento do processo de criação coletivo ínsito a comunidades e povos tradicionais, e considerando a análise realizada até aqui na presente dissertação, passa-se a propor a seguinte regulamentação legal para a tutela do patrimônio cultural imaterial:

\begin{tabular}{|c|c|}
\hline & Projeto de lei \\
\hline & Dispõe sobre a proteção do patrimônio cultural imaterial brasileiro. \\
\hline Art. $1 .^{\circ}$ & $\begin{array}{l}\text { Esta Lei regula direitos e obrigações relativos ao patrimônio cultural imaterial } \\
\text { brasileiro e reconhece a proteção de direitos morais para os grupos e as } \\
\text { comunidades que produzem manifestações culturais de natureza imaterial sobre suas } \\
\text { criações coletivas. }\end{array}$ \\
\hline Art. $2 .^{\circ}$ & $\begin{array}{l}\text { Constituem patrimônio cultural imaterial brasileiro os bens de natureza imaterial, } \\
\text { tomados individualmente ou em conjunto, portadores de referência à identidade, à } \\
\text { ação, à memória dos diferentes grupos formadores da sociedade brasileira, nos quais } \\
\text { se incluem: } \\
\text { as formas de expressão; } \\
\text { I - os modos de criar, fazer e viver; } \\
\text { II - tradições e expressões orais; } \\
\text { III - expressões artísticas; } \\
\text { IV - práticas sociais, rituais e atos festivos; }\end{array}$ \\
\hline
\end{tabular}




\begin{tabular}{|c|c|}
\hline & $\begin{array}{l}\text { V - conhecimentos e práticas relacionados à natureza e ao universo; } \\
\text { VI - técnicas artesanais tradicionais; } \\
\text { VII - instrumentos, objetos, artefatos e lugares culturais associados às práticas, } \\
\text { representações, expressões, conhecimentos, vivências culturais coletivas do } \\
\text { trabalho, da religiosidade, do lazer e da vida social e técnicas referentes às } \\
\text { manifestações da cultura imaterial; } \\
\text { VIII - os ambientes, árvores, fontes lustrais, grutas e outros elementos da } \\
\text { natureza que se revistam de significado cultural para as comunidades; } \\
\text { IX - o patrimônio vivo, constituído por grupos de pessoas detentoras das formas } \\
\text { de expressão da cultura popular e da cultura tradicional. }\end{array}$ \\
\hline Art. 3. & $\begin{array}{l}\text { O Estado brasileiro, com a colaboração da comunidade, promoverá e protegerá o } \\
\text { patrimônio cultural brasileiro, por meio de inventários, registros, vigilância, } \\
\text { tombamento e desapropriação, e de outras formas de acautelamento e preservação: } \\
\S 1 .^{\circ} \text { A lei ordinária regulará o modo como será exercida a guarda e a proteção do } \\
\text { patrimônio imaterial no âmbito federal, estadual e municipal. } \\
\S 2 .^{\circ} \text { O registro de manifestações culturais é meramente declaratório e não } \\
\text { constitutivo de direitos, devendo ser precedido de consentimento da comunidade ou } \\
\text { grupo detentor da manifestação cultural. }\end{array}$ \\
\hline Art. $4^{\circ}$ & $\begin{array}{l}\text { Para os efeitos desta Lei, considera-se: } \\
\text { I - criação comunitária difusa - manifestação cultural de natureza imaterial e } \\
\text { cuja origem não é identificável, que revele as formas de expressão e os saberes } \\
\text { das comunidades tradicionais ou da cultura popular, frutos de herança cultural, } \\
\text { em que o indivíduo e/ou grupo sejam meros intérpretes; } \\
\text { II - criação comunitária - manifestação cultural de natureza imaterial detida por } \\
\text { comunidade ou grupo identificável, que revele as formas de expressão e os } \\
\text { saberes das comunidades tradicionais; } \\
\text { III - comunidade ou grupo - conjunto de pessoas que partilham as mesmas } \\
\text { referências culturais e reconhecem uma identidade comum que desejam } \\
\text { preservar ou desenvolver. } \\
\text { IV - comunidade ou grupo titular de criação comunitária - é o conjunto de } \\
\text { pessoas integrante de grupo ou comunidade que criou determinada manifestação } \\
\text { cultural e foi contatada pela parte interessada para prover informações sobre a } \\
\text { criação comunitária de que é titular. }\end{array}$ \\
\hline Art. 5. ${ }^{\circ}$ & $\begin{array}{l}\text { São assegurados os direitos morais e patrimoniais às comunidades e aos grupos } \\
\text { produtores de criações comunitárias. } \\
\S 1^{\circ} \text { A transmissão dos direitos relativos às criações comunitárias se dá de geração } \\
\text { a geração, exclusivamente no âmbito da comunidade ou do grupo produtores. } \\
\S 2 .^{\circ} \text { Os direitos patrimoniais das comunidades ou grupos sobre as criações } \\
\text { comunitárias não estão sujeitos à limitação temporal, permanecendo em vigor } \\
\text { enquanto a comunidade ou grupo titular da criação comunitária permanecer viva. }\end{array}$ \\
\hline Art. 6. ${ }^{\circ}$ & $\begin{array}{l}\text { Os direitos morais das comunidades ou grupos produtores de criações comunitárias } \\
\text { incluem os direitos de paternidade, à integridade da criação comunitária e de } \\
\text { inédito. } \\
\text { Parágrafo único. Em todas as publicações, em qualquer comunicação ao público ou } \\
\text { utilização das criações comunitárias integrantes do patrimônio cultural imaterial de } \\
\text { grupos ou comunidades vivas e identificáveis, deve haver a indicação de origem da } \\
\text { criação coletiva, sendo sua fonte indicada na forma adequada, ao mencionar a } \\
\text { comunidade e/ou lugar geográfico de onde a criação coletiva utilizada foi derivada. }\end{array}$ \\
\hline Art. $7 .^{\circ}$ & $\begin{array}{l}\text { As seguintes utilizações das criações comunitárias estão sujeitas à autorização da } \\
\text { comunidade ou grupo titular, desde que viva e identificável, quando eles são feitos } \\
\text { com intenção lucrativa ou fora de seu contexto tradicional ou costumeiro: } \\
\quad \text { I - qualquer publicação, reprodução e qualquer distribuição de cópias de }\end{array}$ \\
\hline
\end{tabular}




\begin{tabular}{|c|c|}
\hline & $\begin{array}{l}\text { criações comunitárias; } \\
\text { II - qualquer recitação pública, qualquer transmissão por meios sem fio ou por } \\
\text { cabo e qualquer outra forma de comunicação ao público, das criações } \\
\text { comunitárias. } \\
\text { Parágrafo único. As disposições deste artigo não se aplicam nos seguintes casos: } \\
\text { I - utilização para fins de ensino; } \\
\text { II - utilização em matérias jornalísticas para a difusão e valorização da } \\
\text { expressão cultural, desde que a extensão de tal utilização seja compatível com os } \\
\text { bons costumes. }\end{array}$ \\
\hline Art. $8 .^{\circ}$ & $\begin{array}{l}\text { É assegurado o reconhecimento da titularidade individual ao portador do saber } \\
\text { comunitário tradicional que produza obra própria inovadora. }\end{array}$ \\
\hline Art. 9. ${ }^{\circ}$ & $\begin{array}{l}\text { Para a utilização das criações comunitárias difusas os interessados deverão arcar } \\
\text { com o pagamento de percentual de } 0,1 \% \text { da receita líquida obtida com a } \\
\text { comercialização do produto que explore a criação comunitária difusa ao Fundo } \\
\text { Nacional da Cultura - FNC. } \\
\text { Parágrafo único. Caberá ao Ministério da Cultura administrar o Fundo e garantir que } \\
\text { os recursos a ele disponibilizados sejam revertidos para a conservação do } \\
\text { patrimônio cultural imaterial. }\end{array}$ \\
\hline Art. 10. & $\begin{array}{l}\text { Nos casos de publicação ou reprodução da obra comunitária, é obrigatória a } \\
\text { referência à sua origem e titularidade. } \\
\S 1 .^{\circ} \text { Quem, na utilização, por qualquer modalidade de obra coletiva, deixar de } \\
\text { indicar ou de anunciar como tal a referência à origem e à titularidade responde por } \\
\text { danos na forma da legislação penal e civil. } \\
\S 2 .^{\circ} \text { A utilização econômica de criação coletiva por terceiros exige autorização } \\
\text { expressa da comunidade titular, desde que viva e identificável, sendo facultado a } \\
\text { esta fixar o valor da remuneração que entende devida pelo uso ou reprodução da } \\
\text { obra. }\end{array}$ \\
\hline Art. 11. & $\begin{array}{l}\text { Os direitos patrimoniais assegurados aos autores de obras comunitárias serão } \\
\text { geridos por associações representantes das comunidades e dos grupos produtores. }\end{array}$ \\
\hline Art. 12. & $\begin{array}{l}\text { É ilícito o uso ou a divulgação de criação coletiva quando a autorização não for } \\
\text { requerida ou quando a utilização estiver além dos limites autorizados, respondendo } \\
\text { o responsável por perdas e danos. }\end{array}$ \\
\hline Art. 13. & $\begin{array}{l}\text { Na adoção de políticas públicas de proteção ao patrimônio cultural imaterial } \\
\text { brasileiro, serão adotados critérios de prioridade, levando-se em conta: } \\
\text { I - a antiguidade e historicidade da manifestação; } \\
\text { II - o risco de perda iminente; } \\
\text { III - a importância para a manutenção da identidade da comunidade e de sua } \\
\text { coesão; } \\
\text { IV - a contribuição para o desenvolvimento local. } \\
\text { Parágrafo único. Programas voltados para a consagração de obras-primas do } \\
\text { patrimônio imaterial e para a valorização de mestres em diferentes ofícios integrarão } \\
\text { as políticas públicas voltadas para a proteção do patrimônio cultural imaterial } \\
\text { brasileiro. }\end{array}$ \\
\hline Art. 14. & $\begin{array}{l}\text { Os recursos arrecadados com a utilização econômica das obras coletivas serão } \\
\text { obrigatoriamente utilizados em benefício da comunidade ou grupo titular, na forma } \\
\text { de: } \\
\text { I - ações de fomento à circulação e à transmissão das manifestações } \\
\text { culturais locais; } \\
\text { II - iniciativas voltadas para a preservação do patrimônio cultural } \\
\text { imaterial; } \\
\text { III - ações de preservação da memória; } \\
\text { IV - projetos de geração de renda e de desenvolvimento sustentável }\end{array}$ \\
\hline
\end{tabular}




\begin{tabular}{|l|l|}
\hline & \multicolumn{1}{|c|}{ para a região em que vivem a comunidade ou o grupo titular; } \\
\hline Art. 15. & $\begin{array}{l}\text { As comunidades ou grupos cuja criação coletiva seja indevida e/ou } \\
\text { fraudulentamente reproduzida e divulgada poderão requerer a apreensão dos } \\
\text { exemplares reproduzidos ou a suspensão da divulgação, sem prejuízo da indenização } \\
\text { cabível. }\end{array}$ \\
\hline Art. 16. & $\begin{array}{l}\text { Qualquer ato que importe na destruição, inutilização ou mutilação de expressões do } \\
\text { patrimônio cultural imaterial brasileiro será considerado crime contra o patrimônio } \\
\text { da União, dos Estados ou dos Municípios e, como tal, punível de acordo com o } \\
\text { disposto nas leis penais. }\end{array}$ \\
\hline Art. 17. & Esta lei entra em vigor na data de sua publicação. \\
\hline
\end{tabular}

A proposta ora apresentada não pretende esgotar o tema e elucidar todas as dificuldades identificadas no presente estudo para a regulamentação e proteção do patrimônio cultural imaterial detido por povos e comunidades tradicionais, porém busca contribuir para a identificação dos direitos garantidos constitucionalmente a esses grupos, verificados neste trabalho, refletindo as conclusões da análise realizada sobre os institutos de direito de autor e, em especial, o direito moral aplicável à proteção do patrimônio cultural imaterial. Embora não tenha sido objeto desta dissertação a avaliação dos direitos patrimoniais existentes sobre o patrimônio cultural imaterial, a proposta apresentada disciplina também esse tema, amparada no entendimento de Antônio Chaves ${ }^{450}$ de que a exploração comercial de manifestações culturais imateriais deve reverter benefícios financeiros à comunidade ou ao povo tradicional que a detém.

$\overline{450}$ CHAVES, Antonio. Direitos de autor: princípios fundamentais. Rio de Janeiro: Forense, 1987. p. 81 . 


\section{Capítulo 6 \\ CONSIDERAÇÕES FINAIS}

Ao iniciarmos os estudos para este trabalho, considerávamos importante a proteção às manifestações culturais, especialmente em razão de nossa experiência profissional que permitiu visitas e contato com comunidades e povos tradicionais e conhecer na prática a relevância das manifestações culturais para esses grupos e em seus modos tradicionais de viver. Contudo, imaginávamos que a proteção jurídica a tais direitos dependeria necessariamente de regulamentação e não tínhamos a dimensão de que a importância do patrimônio cultural imaterial detido por povos e comunidades tradicionais já é reconhecida pela Constituição Federal, na qualidade de direito fundamental, dispensando regulamentações para que tais direitos possam ser exercidos.

Assim, ao finalizar este trabalho, a partir da análise da legislação aplicável ao patrimônio cultural imaterial, conseguimos responder aos questionamentos apresentados inicialmente, concluindo que há proteção legal do patrimônio cultural imaterial de titularidade de comunidades ou povos tradicionais vivos e identificáveis. Esta dissertação concluiu que o patrimônio cultural imaterial, nos termos tutelados pela Constituição Federal, é composto por dois feixes de direitos. O primeiro denominado feixe de direitos de interesse público que se destina a toda a sociedade e garante o direito de acesso à cultura e a proteção às manifestações culturais. $\mathrm{O}$ segundo é o feixe de direitos coletivos, i.e., que se relaciona a comunidades ou povos identificáveis e se refere a manifestações culturais criadas e conservadas no escopo de comunidades determináveis. Portanto, os direitos reconhecidos e garantidos a esse feixe de direitos coletivos são: (i) reconhecimento de que a proteção a suas manifestações culturais é direito fundamental e sua tutela é necessária para a garantia da dignidade da pessoa humana e do direito à vida; (ii) integra o direito da personalidade de comunidades vivas e identificáveis; (iii) direitos morais - e em determinados casos também patrimoniais sobre as manifestações culturais que produz, havendo direito exclusivo de utilização, publicação ou reprodução da manifestação cultural - ao menos até que o direito de inédito seja exercido, bem como necessidade de obtenção de autorização para uso 
comercial da manifestação cultural, indicação de sua origem em todos os meios em que venha a ser divulgada.

Em complementação à resposta a essa primeira questão, este trabalho concluiu que as manifestações culturais de povos e comunidades tradicionais não integram o domínio público, isto é, o domínio de todos, enquanto as comunidades que as detêm permaneçam vivas e identificáveis, especialmente em razão da ressalva de que o artigo 45 da LDA apresenta, classificando como não pertencentes ao domínio público as obras de autoria desconhecida que sejam protegidas como conhecimentos étnicos e tradicionais - que é o caso das manifestações integrantes do patrimônio cultural imaterial.

Uma vez respondida essa questão, o presente estudo concluiu também, em resposta ao segundo questionamento, que o patrimônio cultural imaterial não é objeto do direito de autor em razão de não ser possível precisar o momento de sua criação, tampouco quem é(são) seu(s) autor(es), mas verificou-se que é direito fundamental, nos termos constitucionais, e sua proteção representa direito da personalidade da comunidade ou povo tradicional que a criou, dado que essas comunidades devem ser entendidas como pessoas jurídicas, na medida em que deve ser respeitado seu modo tradicional de organização, e, como sustenta Dalmo Dallari, ${ }^{451}$ não lhe pode ser exigido que realize a formalização de sua constituição por meio de contrato social, se tal prática não pertence à sua realidade.

Logo, uma vez que é reconhecida a concessão de direitos da personalidade à pessoa jurídica, no que couber, nos termos do artigo 82 do Código Civil, sendo reconhecida a necessidade de tutela à sua honra, imagem e direitos morais, e que alguns doutrinadores já reconhecem a possibilidade de a pessoa jurídica ser autora, na qualidade de titular originária de obras coletivas, pode-se concluir que, sendo a comunidade ou povo tradicional equiparado a pessoa jurídica, devem-lhe ser reconhecidos esses mesmos direitos, como o reconhecimento de determinados direitos

451 DALlARI, Dalmo de Abreu. Índios, cidadania e direitos. O índio e a cidadania. São Paulo: Brasiliense, 1983. p. 12. 
da personalidade e dentre eles o reconhecimento e tutela dos direitos morais das comunidades e povos sobre suas manifestações cultural identificáveis.

A partir desse entendimento, embora esta dissertação tenha constatado a impossibilidade de o patrimônio cultural imaterial ser objeto do direito de autor, visto que este cuida de obras de pessoas identificáveis, enquanto aquele de manifestações construídas por coletividades de forma coletiva e transgeracional, conclui-se pelos fundamentos apresentados no parágrafo anterior que ao menos um instituto próprio do direito de autor pode e deve ser aplicado também à tutela do patrimônio cultural imaterial, sempre que este estiver vinculado a comunidades ou povos vivos e identificáveis, qual seja o direito moral, consistente no direito à paternidade da manifestação cultural, da sua integridade, do direito de inédito e da citação de sua origem sempre que utilizada. E, assim, foi possível concluir, em resposta à última questão, que existem direitos morais no patrimônio cultural imaterial. Na hipótese de violação desses direitos morais garantidos às comunidades e povos tradicionais, estes poderão demandar judicialmente a reparação dos danos que tal violação ocasionar, tal como ocorre nas hipóteses em que uma pessoa jurídica tem sua honra ou imagem afetadas pela conduta de terceiros.

Uma vez identificados tais direitos e a tutela relacionada aos direitos morais do patrimônio cultural, esta dissertação avaliou entendimentos diversos de doutrinadores sobre a forma de regular esse tema, tendo inclusive considerado sistemas já adotados em outros países, concluindo pela pertinência de se estabelecer um regime sui generis para regulação do patrimônio cultural imaterial, reconhecendo ser este um dos instrumentos para garantir a efetividade do disposto no artigo 216 da Constituição Federal $^{452}$. Assim, apresentou-se Projeto de Lei n. ${ }^{\circ}$ 7.684, de 2006, proposto para regular o tema, mas que já se encontra arquivado desde 31 de janeiro de 2007, sem que tenha sido encaminhado ao Congresso Nacional, ${ }^{453}$ indicando as sugestões que merecem elogios em referida proposta, bem como aquelas que demandam aprimoramento, para

\footnotetext{
452 BARBOSA, João Mitia Antunha. Les lieux des savoirs autochtones. Identité, territoire et droits intellectuels. Sarrebruck: Editions Universitaires Européennes, 2012.

453 Conforme informação disponível em: <http://www.camara.gov.br/proposicoesWeb/ fichadetramitacao?idProposicao=338981 > . Acesso em: 24 abr. 2014.
} 
ao final expor a proposta de norma sui generis para regular o patrimônio cultural imaterial em linha com os argumentos e análises realizados na presente pesquisa.

O objetivo deste trabalho era exatamente realizar a análise das normas atualmente em vigor no ordenamento jurídico nacional para avaliar a possibilidade de se sustentar a existência de direitos morais no patrimônio cultural imaterial, sendo possível a partir do estudo efetuado defender a existência desses direitos àquelas comunidades e povos tradicionais que permanecem vivos e identificáveis e se relacionam com determinadas manifestações culturais, devendo ser reconhecidos seus direitos morais, e que a utilização e exploração de suas manifestações não podem ser apropriadas por terceiros sem seu consentimento e sem que se reconheçam seus direitos morais, à paternidade, ao reconhecimento de sua titularidade, à integridade da manifestação e à indicação de sua origem.

Além do objetivo inicialmente pretendido, esta dissertação também permitiu a conclusão de que existem direitos a serem garantidos às comunidades e povos tradicionais pela Constituição Federal e que, em função de serem direitos da personalidade e fundamentais, possuem aplicação imediata e independem de regulamentação para serem exigíveis por seus titulares. Portanto, na hipótese de violação a tais direitos, seus titulares podem questionar e exigir judicialmente a reparação dos danos sofridos. De toda maneira, ainda que existam direitos já garantidos, o presente trabalho também pôde concluir que a regulamentação por um sistema sui generis, que esclareça os direitos atualmente já garantidos, bem como discipline novas obrigações e direitos relacionados ao tema, é necessária e poderá viabilizar os princípios constitucionais de proteção e preservação do patrimônio cultural imaterial, bem como a garantia dos direitos conferidos aos povos que contribuíram para o processo civilizatório nacional.

A sugestão de norma apresentada nesta dissertação não possui a pretensão de esgotar o tema, mas objetiva auxiliar a construção de normas e políticas públicas, baseadas nos fundamentos analisados neste trabalho, de modo a garantir não apenas o direito de acesso à cultura, mas também o reconhecimento do direito inerente às comunidades e povos que geram manifestações culturais como parte de seu ser e existência, e que contribuem para a manutenção da diversidade cultural nacional. 


\section{REFERÊNCIAS}

\section{BIBLIOGRAFIA JURÍDICA CITADA.}

AFONSO, Otávio. Direito autoral: conceitos essenciais. Barueri: Manole, 2009.

ALESSI, Renato. Sistema istituzionale del diritto ammnistrativo italiano. Milano: Giufrè, 1953.

ALEXY, Robert. Colisão de direitos fundamentais e realização de direitos fundamentais no estado de direito democrático. Revista de Direito Administrativo, Rio de Janeiro: Renovar, v. 217, p. 58, jul.-set. 1998.

—. Teoria dos direitos fundamentais. Tradução de Virgílio Afonso da Silva. 2. ed. São Paulo: Malheiros, 2011.

ARAÚJO, Luiz A. D.; NUNES JUNIOR, Vidal S. Curso de direito constitucional. 3. ed. São Paulo: Saraiva, 2003.

ASCARELLI, Tullio. Teoría de la concurrencia y de los bienes inmateriales. Traducción de E. Verderla y L. Suáres-Llanos. Studia albornotiana. Publicaciones del Real Colegio de España en Bolonia. Barcelona: Bosh, 1970.

ASCENSÃO, José de Oliveira. Direito autoral. 2. ed. São Paulo: Renovar, 1997.

—. Direito civil, direito de autor e direitos conexos. Coimbra: Coimbra Ed., 2012.

BAPTISTA, Fernando Mathias; VALLE, Raul Silva Telles. Os povos indígenas frente ao direito autoral e de imagem. São Paulo: Instituto Socioambiental, 2004.

BARBOSA, Carla G. Antunha; BARBOSA, João M. Antunha; BARBOSA, Marco A. Direito a diferença na sociedade da informação: os direitos indígenas na 
Constituição brasileira. Revista do Instituto dos Advogados de São Paulo, São Paulo: RT, ano 10, n. 20, p. 62, jul.-dez. 2007.

BARBOSA, Denis Borges. Uma introdução à propriedade intelectual. 2. ed. Rio de Janeiro: Lumen Juris, 2003.

BARBOSA, João Mitia Antunha. Les lieux des savoirs autochtones. Identité, territoire et droits intellectuels. Sarrebruck: Editions Universitaires Européennes, 2012.

BARBOSA, Marco Antonio. Autodeterminação: direito à diferença. São Paulo: Plêiade; Fapesp, 2001.

BITTAR, Carlos Alberto. Contornos atuais do direito do autor. São Paulo: RT, 1992.

Direito de autor. 4. ed. atual. por Eduardo C.B. Bittar. São Paulo: Forense Universitária, 2008.

- Metodologia da pesquisa jurídica: teoria e prática da monografia para os cursos de direito. 10. ed. São Paulo: Saraiva, 2012.

. Os direitos da personalidade. 5. ed. rev. e atual. por Eduardo Bittar. São Paulo: Forense Universitária, 2001.

—. Teoria geral do direito civil. Rio de Janeiro: Forense Universitária, 1995.

— - Verbete "obra estética”. Enciclopédia Saraiva do Direito. São Paulo: Saraiva, 1977. v. 55, p. 236.

—; BITTAR FILHO, Carlos Alberto. Tutela dos direitos da personalidade e dos direitos autorais nas atividades empresariais. 2. ed. São Paulo: RT, 2001.

BONAVIDES, Paulo. Curso de direito constitucional. 26. ed. São Paulo: Malheiros, 2011. 
BRANCO, Sérgio. O domínio público no direito autoral brasileiro: uma obra em domínio público. Rio de Janeiro: Lumen Juris, 2011.

BULOS, Uadi Lammêgo. Curso de direito constitucional. 6. ed. rev. e atual. São Paulo: Saraiva, 2011.

CANÇADO TRINDADE. Voto razonado del Juez. Caso de la Comunidad Indígena Sawhoyamaxa versus Paraguay. Disponível em: <http://www.cidh.oas.org/ Ninez/Sawhoyamaxa (80)/VOTO Cançado.doc-09/17/2009>. Acesso em: 20 fev. 2014.

CANOTILHO, Gomes J. J. Direito constitucional. 5. ed. Coimbra: Coimbra Ed., 1991.

CARBONI, Guilherme. Direito autoral e autoria colaborativa: na economia da informação em rede. São Paulo: Quartier Latin, 2010.

—. O direito de autor na obra multimídia. São Paulo: Quartier Latin, 2003.

CAMPOS, Diogo Leite de Campos; CHINELLATO, Silmara Juny de Abreu. Pessoa humana e direito. São Paulo: Almedina, 2009.

CERQUEIRA, João da Gama. Tratado da propriedade industrial. Versão atualizada por Newton Silveira e Denis Borges Barbosa. Rio de Janeiro: Lumen Juris, 2010.

CHAVES, Antônio. Direitos de autor: princípios fundamentais. Rio de Janeiro: Forense, 1987.

CHINELlATO, Silmara Juny de Abreu (Coord.). Código Civil interpretado: artigo por artigo, parágrafo por parágrafo. Organização de Antonio Cláudio da Costa Machado. 4. ed. Barueri: Manole, 2011.

Direito de autor e direitos da personalidade: reflexões à luz do Código Civil. 2008. Tese (Concurso de Professor Titular de Direito Civil) - Faculdade de Direito da Universidade de São Paulo, São Paulo. 
Tutela civil do nascituro. São Paulo: Saraiva, 2003.

— releitura dos ancestrais institutos. Reflexos no direito autoral. Revista do Direito Autoral da ABDA, n. 1, p. 67-68, ago. 2004.

COSTA NETTO, José Carlos. Direito autoral no Brasil. 2. ed. São Paulo: FTD, 1998.

CUNHA JUNIOR, Dirley da. Controle judicial das omissões do poder público. 2. ed. São Paulo: Saraiva, 2008.

DALLARI, Dalmo de Abreu. Índios, cidadania e direitos. $O$ índio e a cidadania. São Paulo: Brasiliense, 1983.

DE CUPIS, Adriano. Os direitos da personalidade. Lisboa: Morais Editora, 1961.

—. Riservatezza e segretto (Dirrito a). Novissimo Digesto Italiano. Torino: UTET, 1969.

DE MATTIA, Fábio M. Direitos da personalidade: aspectos gerais. Revista de Direito Civil, Imobiliário, Agrário e Empresarial, ano 2, p. 24, jan.-mar. 1978.

DESBOIS, Henry. Le Droit D’Auter en France. 2. ed. Paris: Dalloz, 1996.

DRUMMOND, Victor Gameiro. A tutela jurídica das expressões culturais tradicionais. 2001. Tese (Mestrado) - Universidade de Lisboa, Faculdade de Direito, Lisboa. No prelo.

EDELMAN, Bernard. Droit d'auteur, droits voisins. Droit dáuter et marché. Pariz: Dalloz, 1993.

FERREIRA FILHO, Manoel Gonçalves. Direitos humanos fundamentais. 13. ed. São Paulo: Saraiva, 2011. 
FIORILlO, Celso Antônio Pacheco. Curso de direito ambiental brasileiro. 13. ed. São Paulo: Saraiva, 2012.

GOGLIANO, Daisy. Direitos privados da personalidade. 1982. Dissertação (Mestrado) - Fadusp.

GOMES, Luis Roldão de Freitas. Noção de pessoa no direito brasileiro. Direitos da personalidade. Boletim da Faculdade de Direito, Coimbra, n. 69, p. 35, 1993.

GOMES, Orlando. Introdução ao direito civil. 10. ed. Rio de Janeiro: Forense, 1992.

GRAU-KUNTZ, Karin. A interface da propriedade intelectual com o direito antitruste. Palestra proferida na Faculdade de Direito da Universidade de São Paulo em 22 de agosto de 2011. Disponível em: <http://www.ibpibrasil.org/40693/64901.html>. Acesso em: 10 nov. 2011.

HESSE, Konrad. Elementos de direito constitucional da República Federal da Alemanha. Tradução da 20. ed. alemã por Luis Afonso Heck. Porto Alegre: Fabris, 1998.

JESSEN, Henry. Direitos intelectuais. Rio de Janeiro: Itaipu, 1967.

KAYSER, Pierre. La proteción de la vie privée: protection du secret de la vie privée. Marselha: Presses Universitaires d'Aux-Marselle, 1984.

LIMONGI FRANÇA, Rubens. Direitos da personalidade. Coordenadas fundamentais. Revista dos Tribunais, ano 72, v. 567, p. 9-16, jan. 1983.

- Manual de direito civil. 4. ed. São Paulo: RT, 1980.

LISBOA, Roberto Senise. A obra de folclore e sua proteção. In: BITTAR, Eduardo C. B.; CHINELLATO, Silmara Juny (Coord.). Estudos de direito de autor, direito da personalidade, direito do consumidor e danos morais: homenagem ao Professor Carlos Alberto Bittar. Rio de Janeiro: Forense Universitária, 2002. 
LORENZETTI, Ricardo Luís. Fundamentos do direito privado. Tradução de Vera Maria Jacob de Fradera. São Paulo: RT, 1998.

MANCUSO, Rodolfo de Camargo. Comentários ao Código de Proteção do Consumidor. São Paulo: Saraiva, 1991.

MANSO, Eduardo Vieira. Contratos de direito autoral. São Paulo: RT, 1989.

—. Direito autoral. São Paulo: Bushatsky, 1980.

MARCHESAN, Ana Maria Moreira. A tutela do patrimônio cultural sob o enfoque do direito ambiental. Porto Alegre: Livraria do Advogado, 2007.

MARÉS, Carlos Frederico. A proteção jurídica dos bens culturais. Cadernos de Direito Constitucional e Ciência Política, São Paulo, n. 2, p. 19, 1993.

MARQUES, João Paulo Fernandes Remédio. Propriedade intelectual e interesse público. Boletim da Faculdade de Direito de Coimbra - BFD, n. 79, p. 293-354, 2003.

MAXIMILIANO, Carlos. Hermenêutica e aplicação do direito. Rio de Janeiro: Forense, 2005.

MILEO, Bruno Alberto P.; SOARES, Gysele A. A cultura tradicional e o direito autoral. In: SEMINÁRIO PATRIMÔNIO CULTURAL E PROPRIEDADE INTELECTUAL: PROTEÇÃO DO CONHECIMENTO E DAS EXPRESSÕES CULTURAIS TRADICIONAIS. Anais... Belém, 13-15.10.2004. Organizado por Eliane Moreira, Carla Arouca Belas, Benedita Barros, Antônio Pinheiro. Belém: Cesupa/MPEG, 2005. p. 177-193.

MIRANDA, Marcos Paulo de Souza. Tutela do patrimônio cultural brasileiro: doutrina, jurisprudência, legislação. Belo Horizonte: Del Rey, 2006.

MIRKINE-GUÉTZÉVITCH, Boris. As novas tendências do direito constitucional. Tradução de Cândido da Mota Filho. São Paulo: Cia. Ed. Nacional, 1933. 
MOLINARO, Carlos Alberto; DANTAS, Fernando Antonio de Carvalho. Comentário aos artigos 215 e 216. In: CANOTILHO, J.J. Gomes; MENDES, Gilmar F.; SARLET, Ingo W.; STRECK, Lenio L. (Coord.). Comentários à Constituição do Brasil. São Paulo: Saraiva, 2013.

MONREAL, Eduardo Novoa. Derecho a la vida privada y libertad de información. 2. ed. México: Siglo Veintiuno, 1981.

MORAES, Walter. Direito de autor. In: LIMONGI FRANÇA, Rubens (Org.). Enciclopédia Saraiva do Direito. São Paulo: Saraiva, 1977. v. 9.

—. Questões de direito de autor. São Paulo: RT, 1977.

MORATO, Antonio Carlos. A proteção jurídica do bem ambiental. Revista do Instituto dos Advogados de São Paulo, São Paulo: RT, n. 9, p. 24-39, 2002.

—. Direitos de autor em obra coletiva. 2. ed. São Paulo: Saraiva, 2007. No prelo.

MOREIRA, Eliane. Conhecimento tradicional e a proteção. T\&C Amazônia, ano V, n. 11, p. 34, jun. 2007.

NABAIS, José Casalta. O quadro jurídico do património cultural. Lisboa: Associação académica da faculdade de direito de Lisboa, 2011.

PICARD, Edmond. O direito puro. 2. ed. Salvador: Livraria Progresso, 1954.

PIOLA-CASELLI, Eduardo. Codice del Diritto di Autore: commentario della nuova legge 22 aprile 1941. Torino: UTET, 1943.

PONTES, Hildebrando. Autoria e obra coletiva. In: PIMENTA, Eduardo Salles. Direitos autorais: estudos em homenagem a Otávio Afonso dos Santos. São Paulo: RT, 2007.

PONTIER, Jean-Marie; BOURDON, Jacques; RICCI, Jean-Claude. Droit de la Culture. Paris: Dalloz, 1990. p. 90. 
REISEWITZ, Lúcia. Direito ambiental e patrimônio cultural: direito à preservação da memória, ação e identidade do povo brasileiro. São Paulo: Juarez de Oliveira, 2004.

RIOU, Alain. Le Droit de la Culture et le Droit à la Culture. 2. ed. Paris: ESF, 1996.

RODRIGUES, José Eduardo Ramos. O patrimônio cultural nos documentos Internacionais. In: DERANI, Cristiane; COSTA, José Augusto Fontoura (Org.). Direito ambiental internacional. Santos: Universitária, 2001.

RODRIGUES JUNIOR, Edson Beas. Tutela juridical dos recursos da biodiversidade, dos conhecimentos tradicionais e do folklore: uma abordagem de desenvolvimento social. Rio de Janeiro: Elsevier, 2010.

SALOMÃO FILHO, Calixto. Regulação, desenvolvimento e meio ambiente. In:

(Org.). Regulação e desenvolvimento. 2011. No prelo.

SANTILLI, Juliana. In: MATHIAS, Fernando; NOVION, Henry de (Org.). As encruzilhadas das modernidades: debates sobre biodiversidade, tecnociência e cultura. São Paulo: Instituto Socioambiental, 2006.

Conhecimentos tradicionais associados à biodiversidade: elementos para a construção de um regime jurídico sui generis de proteção. In: VARELLA, Marcelo Dias; PlATIAU, Ana Flávia Barros (Org.). Diversidade biológica e conhecimentos tradicionais. Belo Horizonte: Del Rey, 2004.

—. Socioambientalismo e novos direitos. São Paulo: Peirópolis, 2005.

SILVA, José Afonso da. Comentário contextual à Constituição. 7. ed. São Paulo: Malheiros, 2010.

SILVA, Virgílio Afonso da. Direitos fundamentais: conteúdo essencial, restrições e eficácia. 2. ed. São Paulo: Malheiros, 2011. 
Interpretação conforme a constituição: entre a trivialidade e a centralização judicial. Revista DireitoGV, São Paulo, v. 2, n. 1, p. 191-210, jan.-jun. 2006.

SILVEIRA, Newton. A propriedade intelectual e a nova Lei de Propriedade Industrial: Lei n. ${ }^{0} 9.279$ de 14.05.1996. São Paulo: Saraiva, 1996.

Propriedade intelectual: propriedade industrial, direito de autor, software, cultivares, nome empresarial. 4. ed. rev. e ampl. Barueri: Manole, 2011.

; SANTOS JR., Walter Godoy dos. Propriedade intelectual e liberdade. Revista de Direito Mercantil Industrial, Econômico e Financeiro, São Paulo, Nova Série, v. 45, n. 142, p. 7-24, abr.-jun. 2006.

SIRVINSKAS, Luis Paulo. Tutela constitucional do meio ambiente: interpretação e aplicação das normas constitucionais ambientais no âmbito dos direitos e garantias fundamentais. 2. ed. São Paulo: Saraiva, 2010.

SOUZA, Carlos Aurélio Mota de. Empresas e empresários à luz dos princípios constitucionais do bem comum. Revista do Instituto dos Advogados de São Paulo, São Paulo: RT, ano 13, n. 25, p. 83-109, jan.-jun. 2010.

TELLES JR., Goffredo da Silva. Direito subjetivo. In: LIMONGI FRANÇA, Rubens (Org.). Enciclopédia Saraiva do Direito. São Paulo: Saraiva, [s.d.], v. 28.

WIPO. Intellectual Property Needs and Expectations of Traditional Knowledge Holders: WIPO Report on Fact-finding Missions on Intellectual Property and Traditional Knowledge (1998-1999). WIPO, 2001.

\section{BIBLIOGRAFIA MULTIDISCIPLINAR}

ARRUDA, Rinaldo. Populações tradicionais e a proteção dos recursos naturais em unidades de conservação. Anais do Primeiro Congresso Brasileiro de Unidades de Conservação, v. 1. Conferências e Palestras, 1997. 
BRASIL. Ministério da Educação e Cultura. Proteção e revitalização do patrimônio cultural no Brasil: uma trajetória. Brasília, DF, Secretaria do Patrimônio Histórico e Artístico Nacional, Fundação Nacional Pró-Memória, 1980.

BRAYNER, Natália Guerra. Patrimônio cultural imaterial: para saber mais. Brasília: IPHAN, 2007.

BRUMANN, Chirstoph. Writing for culture: why a sucessful concept should not be discarded. Current Anthropology, v. 40, Supplement, p. 23, 1999.

COSTA, Tony Leão da. Música, literatura e identidade amazônica no século XX: o caso do carimbó no Pará. Revista ArtCultura, Uberlândia, v. 12, n. 20, p. 61-81, jan.jun. 2010.

CUNHA, Manoela Carneiro da. Cultura com aspas e outros ensaios. São Paulo: Cosacnayf, 2009.

DIEGUES, Antônio Carlos Sant'Ana. Biodiversidade e comunidades tradicionais. São Paulo: NUPAUB-USP, 1999.

FURTADO, Celso. O capitalismo global. São Paulo: Paz e Terra, 1999.

LARAIA, Roque de Barros. Cultura: um conceito antropológico. 14. ed. Rio de Janeiro: Jorge Zahar, 2001 20. ed. Rio de Janeiro: Jorge Zahar, 2006.

MELLO, Luiz Gonzaga de. Antropologia cultural: iniciação, teoria e temas. 13. ed. Rio de Janeiro: Vozes, 2007.

Antropologia cultural: iniciação, teoria e temas. 19. ed. Rio de Janeiro: Vozes, 2011.

MORAIS, Regis de. Estudos de filosofia da cultura. São Paulo: Loyola, 1992. 
PELEGRINI, Sandra C. A.; FUNARI, Pedro Paulo. O que é o patrimônio cultural imaterial. São Paulo: Brasiliense, 2008.

RIBEIRO, Darcy. O processo civilizatório. 2. ed. Rio de Janeiro: Civilização Brasileira, 1972.

SIMÕES, Maria do Socorro; GOLDER, Christophe. Santarém conta... Belém: Cejup, 1995.

\section{ARTIGOS, DOCUMENTOS, OBRAS E DADOS CONSULTADOS ELETRONICAMENTE}

BARATA, Lauro E. S. A economia verde: Amazônia. Ciência e Cultura, São Paulo, v. 64, n. 3, p. 31-35, 2012. Disponível em: <http://cienciaecultura.bvs. br/scielo.php?script=sci_arttext\&pid=S000967252012000300011\&lng=en\&nrm=iso >. Acesso em: 16 abr. 2013.

DIEGUES, Antônio Carlos Sant'Ana. Conhecimento e manejo tradicionais; ciência e biodiversidade. 2000. passim. Disponível em: $<$ http://www.usp.br/nupaub/cienciabio.pdf $>$. Acesso em: 9 jul. 2012.

HADA, Aleksander Ribeiro. O Buriti (Mauritia flexuosa L. f.) na terra indígena Araçá, Roraima: usos tradicionais, manejo e potencial produtivo. 2010. Dissertação (Mestrado) - INPA, Manaus, p. 41-42. Disponível em: $<$ http://www.bibliotecaflorestal.ufv.br/bitstream/handle/123456789/4275/dissertac ao_Aleksander\%20Hada\%20Ribeiro.pdf?sequence=1>. Acesso em: 17 abr. 2014.

MOREIRA, Eliane. Conhecimentos tradicionais como direitos humanos culturais. Revista Internacional de Direito e Cidadania, Instituto Estudos Direito e Cidadania. Edição especial biodiversidade. Erechim: Habilis, 2010. Disponível em: $<\mathrm{http} / / /$ www.reidespecial.org.br/?CONT=00000252>. Acesso em: 20 fev. 2014.

POSNER, Richard A. Creating a Legal Framework for Economic Development. 13 The World Bank Research Observer, 1998, p. 1-9. Disponível em: 
$<\mathrm{http}$ ://siteresources.worldbank.org/INTLAWJUSTINST/Resources/LegalFramew ork.pdf>. Acesso em: 10 nov. 2011.

ROTMAN, Mônica; CASTELLS, Alicia Norma González de. Patrimônio e cultura: processos de politização, mercantilização e construção de identidades. Disponível em: $\quad<$ http://www.abant.org.br/conteudo/livros/PatrimonioCultural.pdf $>$. Acesso em: 3 jul. 2012.

SONCINI, Luana. Política de patrimônio cultural imaterial na América Latina: análise dos processos de identificação e registro no Brasil e no México. 2012. Dissertação (Mestrado em Integração da América Latina) - Integração da América Latina, Universidade de São Paulo, São Paulo. Disponível em: $<$ http://www.teses.usp.br/teses/disponiveis/84/84131/tde-12072012-155540/>. Acesso em: 4 abr. 2014.

\section{NORMAS E ACÓRDÃOS CONSULTADOS}

BRASIL. Constituição Federal, 1988.

BRASIL. Decreto n. ${ }^{0}$ 75.699, de 6 de maio de 1975. Diário Oficial da União. Brasília, DF, 07 mai. 1975.

BRASIL. Decreto n. ${ }^{\circ}$ 6.040, de 7 de fevereiro de 2007. Disponível em: $<$ http://www.planalto.gov.br/ccivil_03/_ato2007-2010/2007/decreto/d6040.htm>. Acesso em: 4 jul. 2013.

BRASIL. Decreto-lei n. ${ }^{\circ}$ 25, de 30 de novembro de 1937. Diário Oficial da União, Brasília, DF, 6 dez. 1937.

BRASIL. Decreto-lei n. ${ }^{\circ}$ 4.657, de 04 de setembro de 1942. Diário Oficial da União, Brasília, DF, 9 set. 1942.

BRASIL. Lei n. ${ }^{0}$ 5.988, de 14 de dezembro de 1973. Diário Oficial da União. Brasília, DF, 15 dez. 1973. 
BRASIL. Lei n. ${ }^{\circ}$ 9.609, de 19 de fevereiro de 1998. Diário Oficial da União. Brasília, 20 fev. 1998.

BRASIL. Lei n. ${ }^{\circ}$ 9.610, de 19 de fevereiro de 1998. Diário Oficial da União. Brasília, 20 fev. 1998.

BRASIL. Medida Provisória n. ${ }^{\circ}$ 2.186-16/2001. Diário Oficial da União. Brasília, 24 ago. 2001.

BRASIL. Ministério da Educação e Cultura. Proteção e revitalização do patrimônio cultural no Brasil: uma trajetória. Brasília: Secretaria do Patrimônio Histórico e Artístico Nacional e Fundação Nacional Pró-Memória, 1980.

BRASIL, Portaria FUNAI - Fundação Nacional do Índio n ${ }^{\circ}$ 177, de 16 de fevereiro de 2006. Diário Oficial da União. Brasília, 20 fev. 2006.

BRASIL, Projeto de Lei n. ${ }^{\circ} 7.684$ de 2006. Disponível em $<$ http://www.camara.gov.br/proposicoesWeb/prop_mostrarintegra;jsessionid=D09 5E70A2B4358EC67B427034B483D4C.proposicoesWeb1?codteor=431559\&filen ame $=$ PL+7684/2006>. Acesso em: 5 abr. 2014.

OMPI, UNESCO. Model provisions for national laws on the protection of expressions of folklore against illicit exploitation and other prejudicial actions. 1985.

TJRS, Apelação Cível n. ${ }^{\circ}$ 70040610040, Rel. Des. Ana Lúcia Carvalho Pinto Vieira Rebeout, j. 05.06.2014.

TJSP, 4. ${ }^{a}$ Câmara de Direito Privado, Apelação n. ${ }^{o}$ 0004522-48.2009.8.26.0554, Rel. Des. Carlos Henrique Miguel Trevisan, j. 26.06.2014.

UNESCO, Convenção para a Salvaguarda do Patrimônio Cultural Imaterial, 2003.

UNESCO, Convenção para a Proteção do Patrimônio Mundial, Cultural e Natural, 1972.

UNESCO, Convenção sobre a Proteção e Promoção da Diversidade das Expressões Culturais, 2005. 
UNESCO, Declaração Universal sobre a Diversidade Cultural, 2002. Preâmbulo.

\section{SITES CONSULTADOS}

$<$ www.wipo.int $>$

$<$ http://portal.iphan.gov.br/portal/montarDetalheConteudo.do?id=18359\&sigla=Noticia $\&$ retorno $=$ detalheNoticia $>$.

$<$ http://portal.iphan.gov.br>.

$<$ http://www.iphan.gov.br/bcrE/pages/folProcessoRegistroE.jsf $>$.

$<$ http://www.iphan.gov.br/bcrE/pages/folBemCulturalRegistradoE.jsf $>$.

$<$ http://www.unesco.org/new/pt/brasilia/>.

$<$ http://portal.iphan.gov.br>.

$<$ http://www.wipo.int/export/sites/www/tk/en/documents/pdf/1982-folklore-modelprovisions.pdf $>$.

$<$ http://www.camara.gov.br/proposicoesWeb/fichadetramitacao?idProposicao=338981>.

$<$ http://www.planalto.gov.br/ccivil_03/decreto-lei/del0025.htm>.

$<$ http://www.planalto.gov.br/ccivil_03/leis/L5988.htm>.

$<$ http://www.mtg.org.br/chimarrao.html $>$.

$<$ http://www.cidh.oas.org/Indigenas/Paraguay.12.419.htm>.

$<$ http://www.reidespecial.org.br/?CONT=00000252>.

$<$ http://www.onu.org.br/onu-no-brasil/ompi/> .

$<$ http://unesdoc.unesco.org/images/0018/001887/188700por.pdf $>$.

$<$ http://www.onu.org.br/onu-no-brasil/unesco/>.

$<$ http://www.wipo.int/treaties/en/ip/berne/trtdocs_wo001.html\#P192_37445>. 
$<$ http://portal.iphan.gov.br/portal/montarPaginaSecao.do?id=12553\&retorno=paginaIph an>.

$<\mathrm{http}: / /$ www.wipo.int/tk/en/>.

$<$ http://www.unesco.org/culture/ich/index.php?lg=en\&pg=00011>.

$<$ http://www.unesco.org/culture/ich/index.php?lg=en\&pg=00011\&USL=00531>.

$<$ http://www.cultura.gov.br/consultadireitoautoral/consulta/ $>$.

$<$ http://noticias.pgr.mpf.gov.br/noticias/noticias-dosite/copy_of_constitucional/imprimir?\&UID=8d92565857a6463060ba5cdf84dd75 $2 \mathrm{c} \&$ keepThis $=$ true $\&$ TB_iframe $=$ true $\&$ height $=400 \&$ width $=700>$.

$<$ http://portal.unesco.org/culture/en/files/31318/11866635053tunis_model_law_enweb.pdf/tunis_model_law_en-web.pdf $>$. 